San Jose State University

SJSU ScholarWorks

Master's Theses

Master's Theses and Graduate Research

1992

\title{
Hydrogeology of high-salinity ground water in the "180-foot" pressure aquifer southwest Salinas, Monterey County, California
}

Janet Elaine Heard

San Jose State University

Follow this and additional works at: https://scholarworks.sjsu.edu/etd_theses

\section{Recommended Citation}

Heard, Janet Elaine, "Hydrogeology of high-salinity ground water in the "180-foot" pressure aquifer southwest Salinas, Monterey County, California" (1992). Master's Theses. 467.

DOI: https://doi.org/10.31979/etd.k7bw-rt6r

https://scholarworks.sjsu.edu/etd_theses/467

This Thesis is brought to you for free and open access by the Master's Theses and Graduate Research at SJSU ScholarWorks. It has been accepted for inclusion in Master's Theses by an authorized administrator of SJSU ScholarWorks. For more information, please contact scholarworks@sjsu.edu. 


\section{INFORMATION TO USERS}

This manuscript has been reproduced from the microfilm master. UMI films the text directly from the original or copy submitted. Thus, some thesis and dissertation copies are in typewriter face, while others may be from any type of computer printer.

The quality of this reproduction is dependent upon the quality of the copy submitted. Broken or indistinct print, colored or poor quality illustrations and photographs, print bleedthrough, substandard margins, and improper alignment can adversely affect reproduction.

In the unlikely event that the author did not send UMI a complete manuscript and there are missing pages, these will be noted. Also, if unauthorized copyright material had to be removed, a note will indicate the deletion.

Oversize materials (e.g., maps, drawings, charts) are reproduced by sectioning the original, beginning at the upper left-hand corner and continuing from left to right in equal sections with small overlaps. Each original is also photographed in one exposure and is included in reduced form at the back of the book.

Photographs included in the original manuscript have been reproduced xerographically in this copy. Higher quality $6 "$ x 9 " black and white photographic prints are available for any photographs or illustrations appearing in this copy for an additional charge. Contact UMI directly to order.

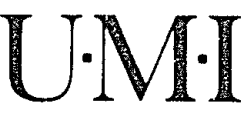

University Microfilms Internalıonal

A Bell \& Howell Information Company 

Order Number 1351038

Hydrogeology of high-salinity ground water in the "180-foot" pressure aquifer southwest Salinas, Monterey County, California

Heard, Janet Elaine, M.S.

San Jose State University, 1992

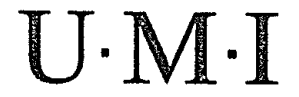

300 N. Zecb Rd.

Ann Arbor, MI 48106 



\title{
HYDROGEOLOGY OF HIGH-SALINITY GROUND WATER IN THE "180-FOOT" PRESSURE AQUIFER SOUTHWEST SALINAS, MONTEREY COUNTY, CALIFORNIA
}

\author{
A Thesis \\ Presented to \\ The Faculty of the Department of Geology \\ San Jose State University
}

\author{
In Partial Fulfillment \\ of the Requirements for the Degree \\ Master of Science
}

By

Janet Elaine Heard

December 1992 
APPROVED FOR THE DEPARTMENT OF GEOLOGY
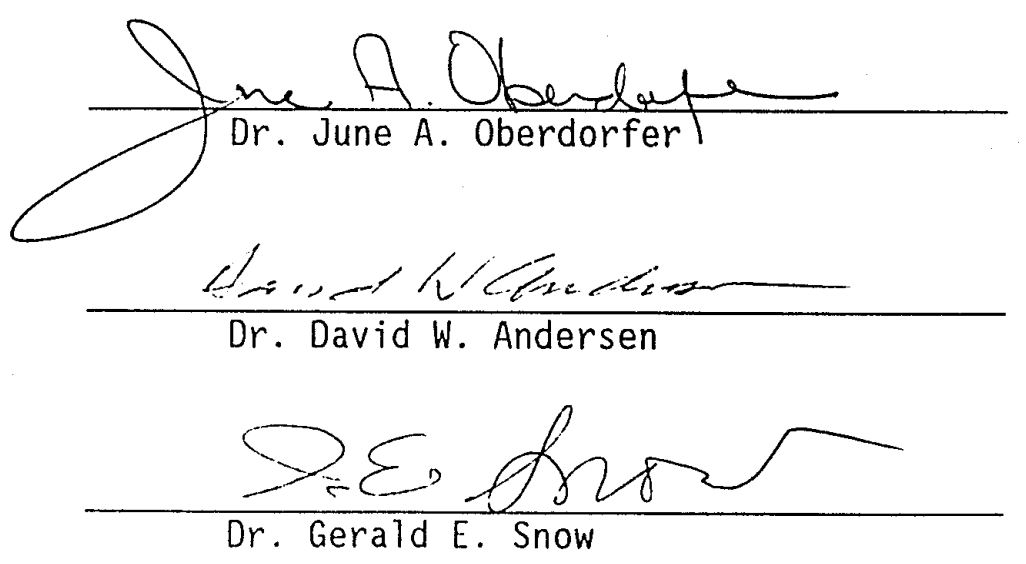

APPROVED FOR THE UNIVERSITY

Th. Son dewaxdownti 
ABSTRACT

HYDROGEOLOGY OF HIGH-SALINITY GROUND WATER IN THE

"180-FOOT" PRESSURE AQUIFER

SOUTHWEST SALINAS, MONTEREY COUNTY, CALIFORNIA

by Janet Elaine Heard

High-salinity ground water was detected as early as 1946 in an area southwest of Salinas, California. Local agencies hypothesized that the salinity was due to agricultural return water percolating downward.

Coarse-grained sediment in the study area is vertically continuous from the "180-foot" pressure aquifer up to ground surface at three locations. Coarse-grained sediment provides a pathway for the downward percolation of agricultural return water.

The general ground water gradient was northwesterly to northerly between 1950 and 1990. Piezometric surface elevations declined an average of $0.36 \mathrm{ft} / \mathrm{yr}$ since 1949. The declining piezometric surface may provide a driving mechanism for the downward movement of high-salinity water.

The water type in the "180-foot" pressure aquifer was classified in 1933 as normal good water dominated by calcium-bicarbonate water. However, in 1977, the predominant water type was sodium-sulphate. This sodium-sulphate water in the "180-foot" pressure aquifer resembles agricultural return water and does not resemble sea water. 


\section{ACKNOWLEDGEMENTS}

The accomplishment of this thesis would not have been possible without the help and support of several people. Dr. June Oberdorfer provided invaluable guidance and advice in selecting a thesis topic, in interpreting the data, and in reviewing this thesis. She was very tolerant and patient through my several delays in working on this thesis. I'm very appreciative of her technical review of this thesis. I would like to thank Dr. David Andersen for being on my committee.

This thesis was initiated with the assistance of Mr. Gene Taylor with the Monterey County Water Resources Agency. Even though he was extremely busy, he took time to meet with me several times, suggested the study area and content, and provided the data. I would like to thank Dr. Gerald Snow with the Monterey County Water Resources Agency for being on my committee. He is extremely busy and I appreciate his spending the time be on my committee and for reviewing this thesis.

I would like to thank Betsy Mathieson for her review of the first draft of this thesis. I have a great deal of confidence in her technical reviews of my professional work and am extremely appreciative of her taking the time to assist with my thesis outside of work.

I would finally like to thank my husband Andy. He is the most important person in my life and I love him dearly. His sense of humor, unfailing support, and the love he gives to me, provide a life worth looking forward to. He sacrificed a great deal during the final months of this thesis. He gave to me the greatest gift of all, our daughter Megan, and took care of her on weekends, while I worked on this thesis. For all of his love and support I am eternally grateful. 
TABLE OF CONTENTS

Page

ABSTRACT ........................ . . . $i_{i}$. .

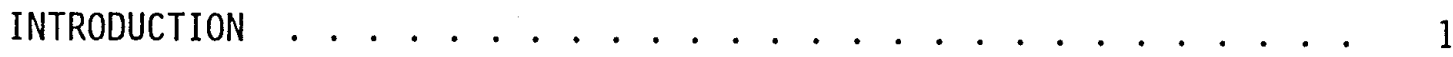

Objective . . . . . . . . . . . . . . . . . 1

Regional Setting .................. 4

Study Area . . . . . . . . . . . . . . . . . 4 4

Previous Work . . . . . . . . . . . . . . . . 8

REGIONAL GEOLOGY ....................... 13

Depositional History ................. . 14

Geologic Structure . . . . . . . . . . . . . . 19

HYDROGEOLOGY . . . . . . . . . . . . . . . . . . 21

Water Table Aquifer................. . 21

Salinas Aquiclude.................. . . 22

"180-Foot" Pressure Aquifer . . . . . . . . . . . . . 22

Intermediate Aquiclude . . . . . . . . . . . . . . 22

"400-Foot" Pressure Aquifer . . . . . . . . . . . . 23

Lower Aquiclude . . . . . . . . . . . . . . . 23

Deep Aquifer . . . . . . . . . . . . . . . 23

METHOD OF INVESTIGATION . . . . . . . . . . . . . . . . . 25

Textural Classification ............... . . 25

Aquifer Chemistry ............... . . 30

Piezometric Surface Elevation . . . . . . . . . . . . . 32 


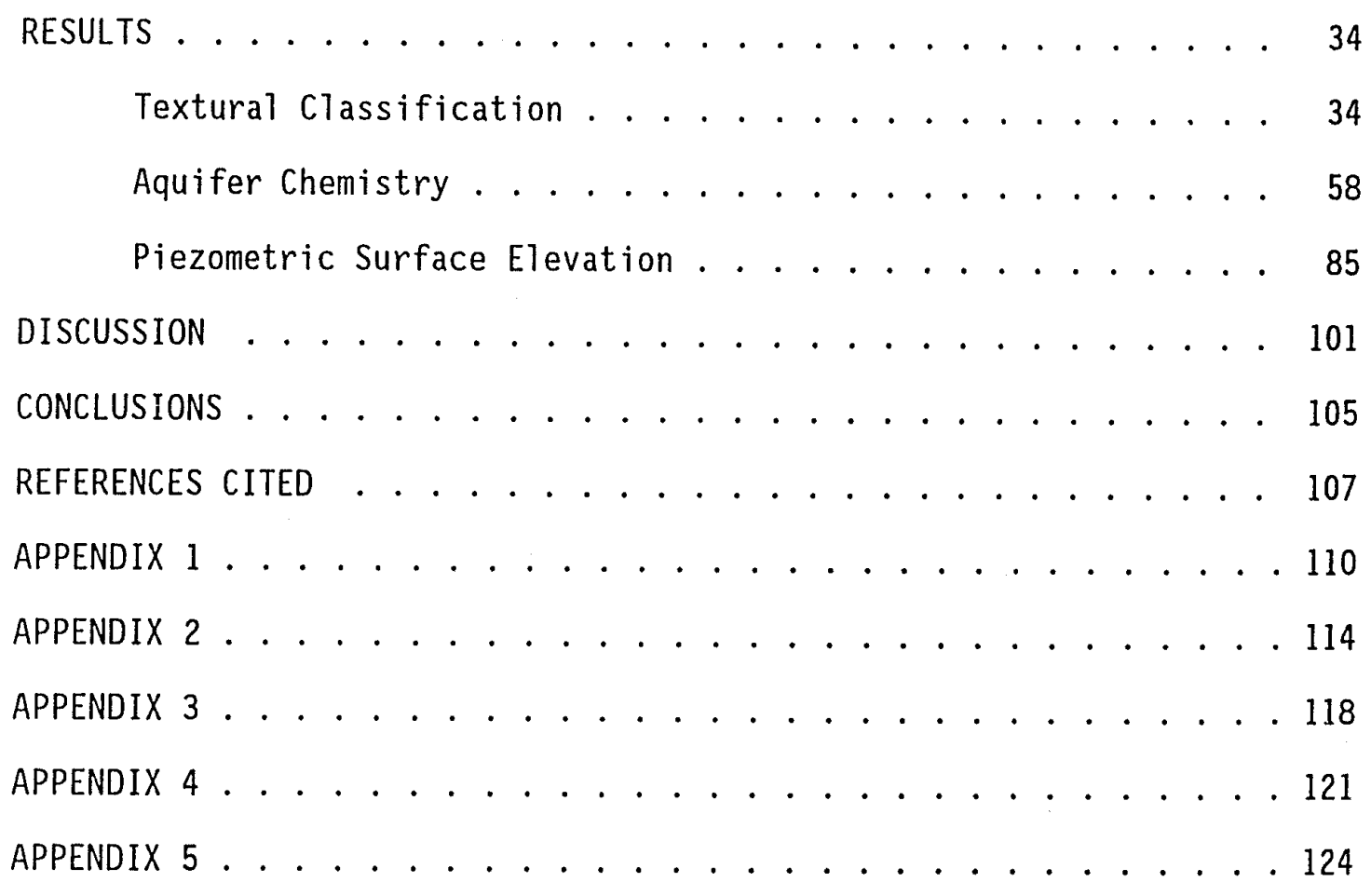




\section{LIST OF ILLUSTRATIONS}

Figure $\quad$ Page

1. Vicinity Map outlining the Study Area . . . . . . . . . . . . 2

2. Study Area Showing Locations of High-salinity Ground Water Plumes . . . . . . . . . . . . . . . . . . 5

3. Map showing Salinas Valley Ground Water Supply Areas. . . . . . 9

4. Geologic Map of Quaternary Deposits in the Study Area . . . . 15

5. Locations of 117 Water We11s Used to Produce Texture Contour Maps of the Study Area and Locations of the Geologic Cross

Sections. . . . . . . . . . . . . . . . . 26

6. Locations of 67 Wells with Water Quality Analyses . . . . . . 31

7. Locations of 30 Water Wells with Historic Piezometric Surface Elevation Measurements. . . . . . . . . . . . 33

8. Texture Contour Map at Elevation -340 Feet. . . . . . . . . . 35

9. Texture Contour Map at Elevation -320 Feet. . . . . . . . . . 36

10. Texture Contour Map at Elevation -300 Feet. . . . . . . . . . 37

11. Texture Contour Map at Elevation -280 Feet. . . . . . . . . . 38

12. Texture Contour Map at Elevation -260 Feet. . . . . . . . . . 39

13. Texture Contour Map at Elevation -240 Feet. . . . . . . . . . 40

14. Texture Contour Map at Elevation -220 Feet. . . . . . . . . . . 41

15. Texture Contour Map at Elevation -200 Feet. . . . . . . . . . 42

16. Texture Contour Map at Elevation -180 Feet. . . . . . . . . . . 43

17. Texture Contour Map at Elevation -160 Feet. . . . . . . . . . . 44

18. Texture Contour Map at Elevation -140 Feet. . . . . . . . . . 45

19. Texture Contour Map at Elevation -120 Feet. . . . . . . . . . . 46

20. Texture Contour Map at Elevation -100 Feet. . . . . . . . . . . 47 
21. Texture Contour Map at Elevation -80 Feet . . . . . . . . . . 48

22. Texture Contour Map at Elevation -60 Feet . . . . . . . . . 49

23. Texture Contour Map at Elevation -40 Feet . . . . . . . . . 50

24. Texture Contour Map at Elevation -20 Feet . . . . . . . . 51

25. Texture Contour Map at Elevation 0 Feet . . . . . . . . 52

26. Cross-Section $A-A^{\prime}$................ 54

27. Cross-Sections $B-B^{\prime}$ and $C-C^{\prime}$.............. 55

28. Cross-Section D-D'................. 56

29. Fence Diagram of Cross Sections $A-A^{\prime}, B-B^{\prime}$ and $C-C^{\prime}$, and $\mathrm{D}-\mathrm{D}^{\prime}$. . . . . . . . . . . . . . . . . 57

30. Representative Stiff Diagrams of Blanco Drain Agricultural Return Water in 1965 and Sea Water. . . . . . . . . . 60

31. Stiff Diagrams of Water Chemistry from We11 14S/2E-23J1 . . . 61

32. Stiff Diagrams of Water Chemistry from Well 14S/2E-23J1 . . . 62

33. Stiff Diagrams of Water Chemistry from We11 14S/2E-23J1 . . . 63

34. Stiff Diagrams of Water Chemistry from Wel1 14S/2E-23J1 . . . 64

35. Stiff Diagrams of Water Chemistry from Well 14S/3E-30El . . . 65

36. Stiff Diagrams of Water Chemistry from Well 14S/3E-30El . . . 66

37. Stiff Diagrams of Water Chemistry from We11 15S/3E-04L1 . . . 68

38. Stiff Diagram of Water Chemistry from Well 15S/3E-04L1 . . . 69

39. Water Zonation Map for 1955 . . . . . . . . . . . . . 70

40. Water Zonation Map for 1960 ................ . 71

41. Water Zonation Map for 1962 . . . . . . . . . . . . . 73

42. Water Zonation Map for 1972-73 . . . . . . . . . . . . . 74

43. Water Zonation Map for 1977 ................. 75 
44. Diagrams for Major Anions and Cations Versus Time for Well

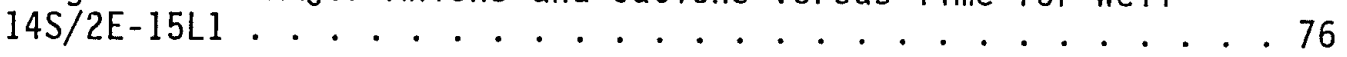

45. Diagrams for Major Anions and Cations Versus Time for Well

14S/2E-23J1 . . . . . . . . . . . . . . . . . 77

46. Diagrams for Major Anions and Cations Versus Time for Well

14S/2E-26A1 ................... 78

47. Diagrams for Major Anions and Cations Versus Time for Well

14S/3E-30E1 ................... . . 79

48. Diagrams for Major Anions and Cations Versus Time for Well

14S/3E-30F1 ................... . . 80

49. Diagrams for Major Anions and Cations Versus Time for Well

14S/3E-33G1 .................... . 81

50. Diagrams for Major Anions and Cations Versus Time for Well

15S/2E-02Q1 ................... 82

51. Diagrams for Major Anions and Cations Versus Time for Well 15S/3E-05Q4 .................... 83

52. Diagrams for Major Anions and Cations Versus Time for Well 15S/3E-07D1 ..................... 84

53. Piezometric Surface Elevation Contours in Fall 1950 . . . . . . 86

54. Piezometric Surface Elevation Contours in Fall 1955 . . . . . . 87

55. Piezometric Surface Elevation Contours in Fall 1960 . . . . . 88

56. Piezometric Surface Elevation Contours in Fall 1965 . . . . . 89

57. Piezometric Surface Elevation Contours in Fall 1970 . . . . . .90

58. Piezometric Surface Elevation Contours in Fall 1975 . . . . . 91

59. Piezometric Surface Elevation Contours in Fall 1980 . . . . . 92

60. Piezometric Surface Elevation Contours in Fall 1985 . . . . . 93

61. Piezometric Surface Elevation Contours in Fall 1990 . . . . . 94

62. Hydrographs of Wells $14 \mathrm{~S} / 2 \mathrm{E}-13 \mathrm{~B} 2$ and $14 \mathrm{~S} / 2 \mathrm{E}-14 \mathrm{E} 1 . . . . .966$

63. Hydrographs of Wells $14 \mathrm{~S} / 2 \mathrm{E}-15 \mathrm{G} 1$ and $14 \mathrm{~S} / 2 \mathrm{E}-22 \mathrm{P} 2 . . . . . .97$ 
64. Hydrographs of Wel1s 14S/3E-30N1 and 15S/2E-01Q1....... . 98

65. Hydrograph of Well 15S/3E-09E3. . . . . . . . . . . . . 99

Table

1. Lithologic Descriptions for Well Logs . . . . . . . . . . 29 


\section{INTRODUCTION}

High-salinity ground water is impacting agricultural row crops in an area southwest of Salinas, California. The California State Water Resources Board (1956) stated that, although the source of the saline water is unknown, the salinity probably is due to agricultural return water percolating downward. According to the Monterey County Water Resources Agency (MCWRA, previously Monterey County Water Flood Control and Water Conservation District) (1971), the quality of ground water in the "180-foot" (55 m) pressure aquifer is Class II irrigation water.

\section{Objective}

The objective of this study was to perform a hydrogeologic investigation of a 27-square-mile area containing high-salinity ground waters between the Salinas River and the City of Salinas, California (Fig. 1). Chemical analyses of ground water have shown an area of highsalinity existing since 1946 in the "180-foot" (55 m) pressure aquifer in the study area (California Department of Water Resources (CDWR, previous7y California Division of Water Resources), 1946).

There are three classifications of irrigation water adopted by the MCWRA (1971). Class I is excellent to good water, regarded as safe and suitable for most plants under any condition of soil or climate, and is defined as having less than $700 \mathrm{ppm}$ total dissolved solids (TDS), electrical conductivity less than 1,000 micromohs/cm, chloride ion concentration less than $175 \mathrm{ppm}$, less than 60 percent sodium, and less than $0.5 \mathrm{ppm}$ boron. 


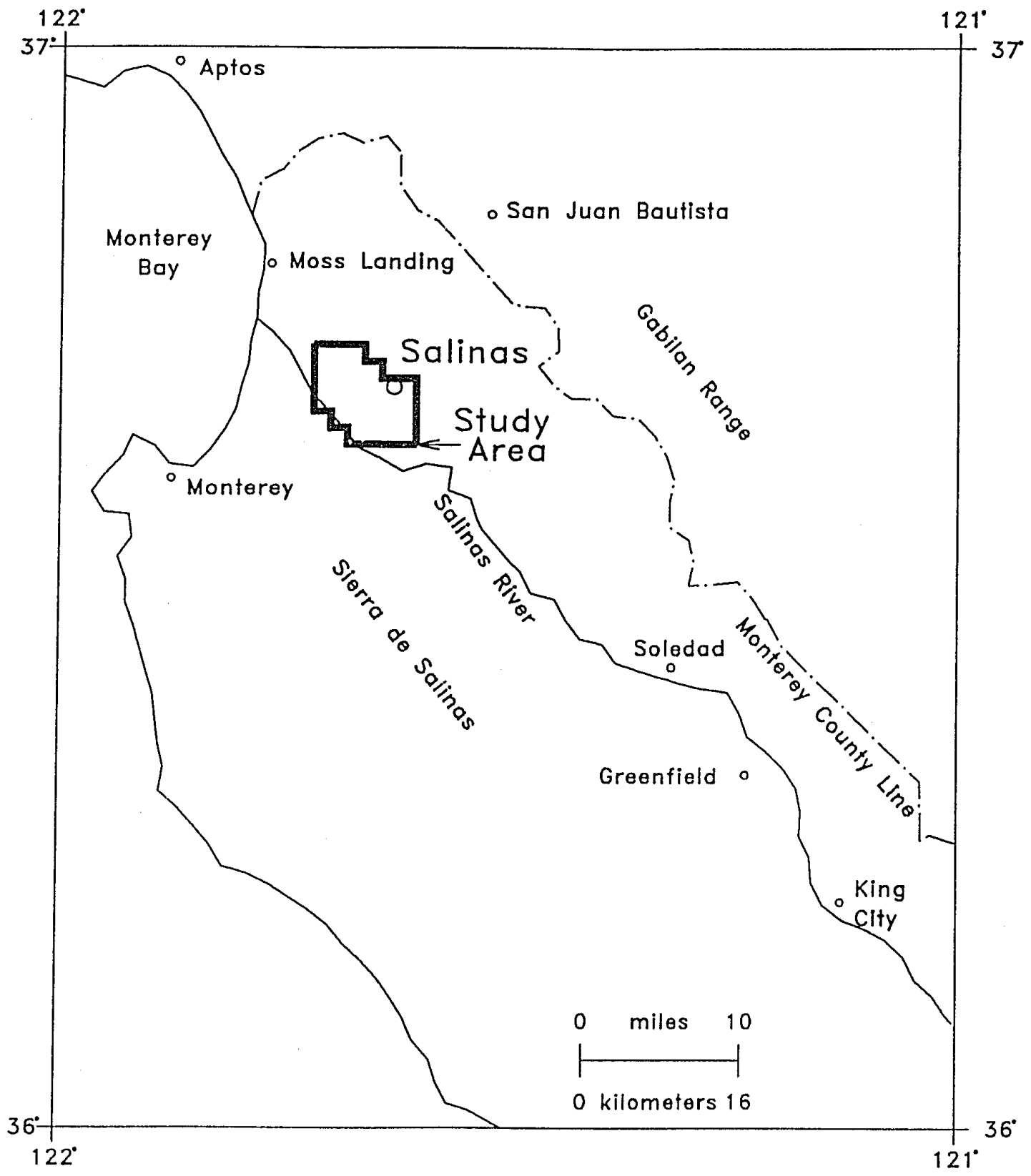

Figure 1. Vicinity map outlining the study area. 
Class II is good to injurious water, regarded as possibly harmful for certain crops under certain conditions of soil or climate, particularly in the higher range of this class, and is defined as having between 700 and 2,000 ppm TDS, electrical conductivity between 1,000 and 3,000 micromohs/cm, chloride ion concentration between 175 and $350 \mathrm{ppm}$, between 60 and 75 percent sodium, and between 0.5 and $2.0 \mathrm{ppm}$ boron.

Class III is injurious to unsatisfactory, regarded as probably harmful to most crops and unsatisfactory for all but the most tolerant, and is defined as having greater than 2,000 ppm TDS, electrical conductivity greater than 3,000 micromohs/cm, chloride ion concentration greater than $350 \mathrm{ppm}$, greater than 75 percent sodium, and greater than $2.0 \mathrm{ppm}$ boron. Within the study area, waters ranged between Class I and Class III between 1954 and 1986. The maximum chloride concentration in the study area was measured at $1110 \mathrm{ppm}$ in 1977 (MCWRA, 1990). This well was subsequently abandoned.

High-salinity ground water generally is the result of (1) saline connate water, (2) sea water intrusion, or (3) downward percolation of saline waters. The high salt content in the vicinity of the "180-foot" pressure aquifer generally is thought to be caused by the downward percolation of agricultural return water through discontinuities in the clay aquiclude that overlies the "180-foot" pressure aquifer (CDWR, 1973).

The MCWRA is interested in (1) determining locations of discontinuities in the clay aquicludes overlying the "180-foot" pressure aquifer, (2) assessing the history of local ground water chemistry, and 
(3) assessing the historical changes in local piezometric surface elevation. A detailed assessment of the local hydrogeology of the area surrounding the high-salinity ground waters will have direct application to decisions made on the means to reduce or prevent further growth or movement of the high-salinity waters in the "180-foot" pressure aquifer.

\section{Regional Setting}

The Salinas Valley is located in the coastal mountain region of central California. The central Coast Ranges consist of several northwest-trending subparallel and predominantly linear mountain belts and intervening structural valleys. The Salinas Valley is bounded by the Gabilan Range on the east and by the Sierra de Salinas on the west. The lower Salinas Valley is situated within Monterey County and is located between the City of Greenfield to the south and Monterey Bay to the north (CDWR, 1970). The study area is located in the lower portion of the Salinas Valley, southwest of the City of Salinas. The highsalinity ground water is centered around the intersection of Blanco Road and Davis Road, known locally as the "Blanco area."

\section{Study Area}

The 27-square mile study area (Fig. 2) is located entirely within the USGS 7.5-minute Salinas Quadrangle. The study area surrounds the high-salinity ground water and includes the following sections: 


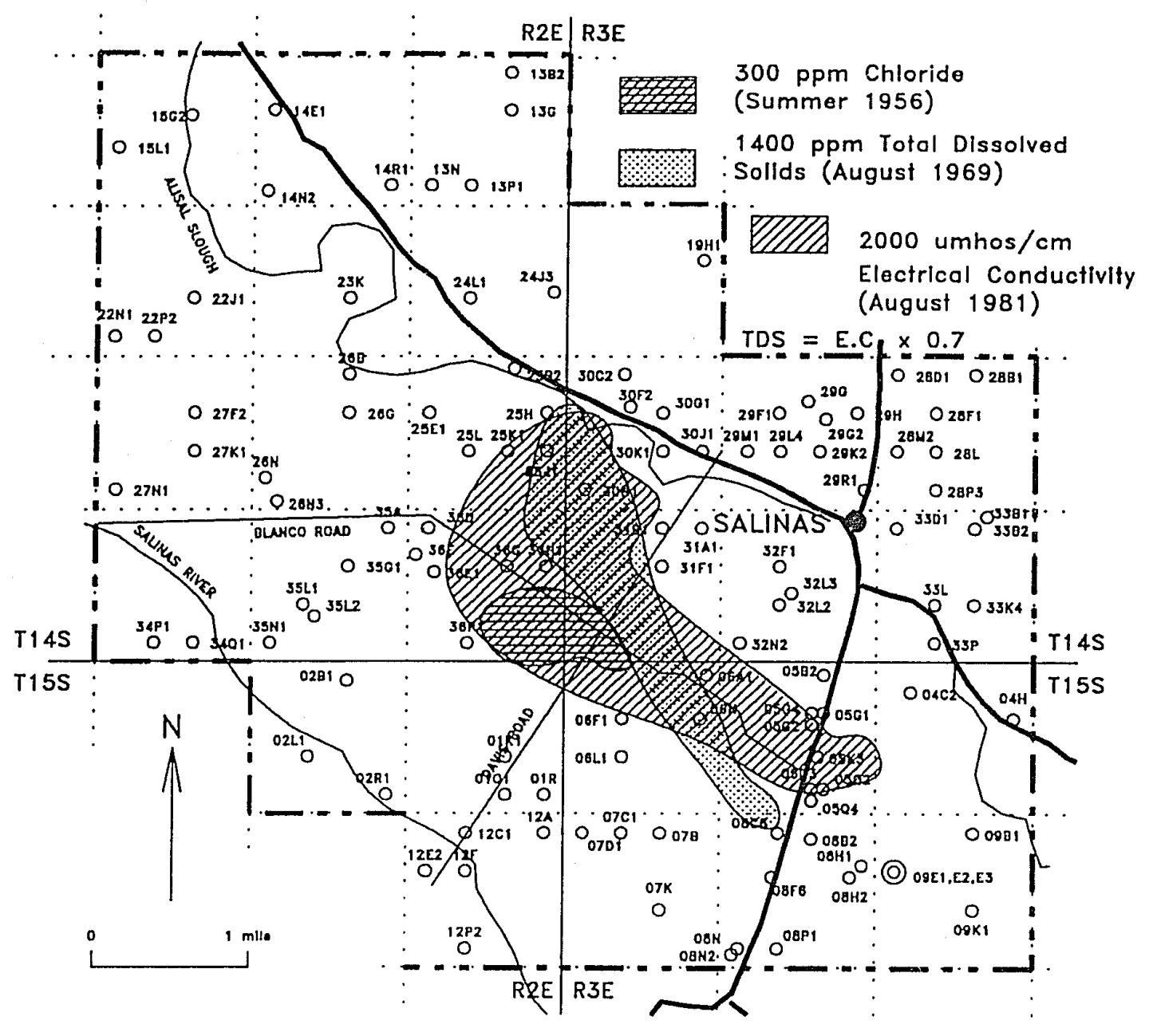

Figure 2. Study area showing locations of high-salinity ground water plumes in the "180-foot" pressure aquifer in 1956, 1969, and 1981. The plume locations represent the boundary between good water and water that is injurious to crops. 


\begin{tabular}{lll} 
TOWNSHIP & RANGE & \multicolumn{1}{c}{ SECTIONS } \\
14 South & 2 East & $\begin{array}{l}13,14,15,22,23,24,25, \\
26,27,34,35, \text { and } 36\end{array}$ \\
14 South & 3 East & $19,28,29,30,31,32$, and 33 \\
15 South & 2 East & 1,2, and 12 \\
15 South & 3 East & $4,5,6,7,8$, and 9
\end{tabular}

The study area is essentially flat. Elevations range from about $20 \mathrm{ft}(6 \mathrm{~m})$ above sea level in the northwest corner of the study area to about $70 \mathrm{ft}(20 \mathrm{~m})$ in the northeast corner of the study area. The study area is bounded to the southwest by $60-$ foot- (18-m-) tal1, north-facing bluffs that may represent the trace of the King City-Reliz fault (Tinstey, 1975). The study area is bounded to the northeast by the boundary between the "Pressure" and the "East Side" ground water areas, based on the source of recharge to the aquifers (CDWR, 1946).

The zone of high-salinity ground water is centered within the study area and is in the general shape of a banana about one mile $(2 \mathrm{~km})$ wide by four miles $(6 \mathrm{~km})$ long. As shown on Figure 2, the high-salinity ground water has been variously mapped using three separate criteria: (1) the concentration of chloride ions, (2) the concentration of total dissolved solids, and (3) the measurement of electrical conductivity. The plume locations shown on Figure 2 represent the boundary between good water and water that is injurious to crops.

The Salinas River flows northwestward along the southwest boundary of the study area then turns northward and flows just outside the western boundary. Alisal Slough meanders northwesterly through the 
northern portion of the study area. The City of Salinas is located in the eastern portion of the study area, and agricultural 1 and planted predominantly in row crops occupies the rest of the study area. The Blanco Drain is the major agricultural drainage system within the Blanco area. The drain collects discharge water from the agricultural crops in the area, which flows through a series of unlined canals, conduits, and flap gates across the study area and then discharges into the Salinas River downstream of the study area. The drainage area covers approximately 6,000 acres and consists of perched ground water and storm water, in addition to the agricultural return water.

It should be mentioned that the quality of water in the Salinas River, downstream from the Blanco Drain discharge area, was found to be too saline for irrigation use during summer flow (CDWR, 1946).

Changes in the piezometric surface elevation in the Salinas Valley are a reflection of the ground water demand versus the ground water recharge. Piezometric surface elevations were measured in 1916-17 and again in 1931-32. An average drop of $20 \mathrm{ft}(6 \mathrm{~m})$ was found in the Salinas vicinity over that time period (CDWR, 1933). A fluctuation of the piezometric surface elevation of about $15 \mathrm{ft}(5 \mathrm{~m})$ was found during the irrigation season of 1944 with average recovery up to within one foot of normal at the culmination of the irrigation season (CDWR, 1946). The CDWR's 1946 study determined that the aquifers in the study area remain saturated at all times and that fluctuations in the piezometric surface elevations and hydraulic gradients in the "180-foot" pressure aquifer were largely governed by pressure relief induced by draft. The 
"180-foot" pressure aquifer was considered full with no change in storage during 1945 (CDWR, 1946).

\section{Previous Work}

The first investigation of the ground water resources of the Salinas Valley was jointly conducted by the CDWR and the MCWRA. The initial study in 1931 and 1932 concluded that the overall quality of water was excellent. At that time the water supply was only slightly greater than the water demand and the authors stated that future sea water intrusion was possible (CDWR, 1933).

The second joint investigation was completed in 1946 by the CDWR and MCWRA (CDWR, 1946) after several wells were abandoned or subjected to use restrictions by excess salinity as early as 1938. They determined that the amount of 1 and in agricultural use, the practice of double cropping, and the population and industry in the area had substantially increased. Demand for ground water was greater than the recharge, and a decline in piezometric surface elevation in the basin was detected. Sea water intrusion was detected beneath an area of about 6,000 acres extending inland about 1.5 miles from the coastline (CDWR, 1946) .

In the 1946 investigation, the valley was divided into five interconnected ground water areas: the Pressure, East Side, Forebay, Arroyo Seco Cone, and Upper Valley (Fig. 3). These designations are still used, although the Arroyo Seco Cone sub-area is included as part 


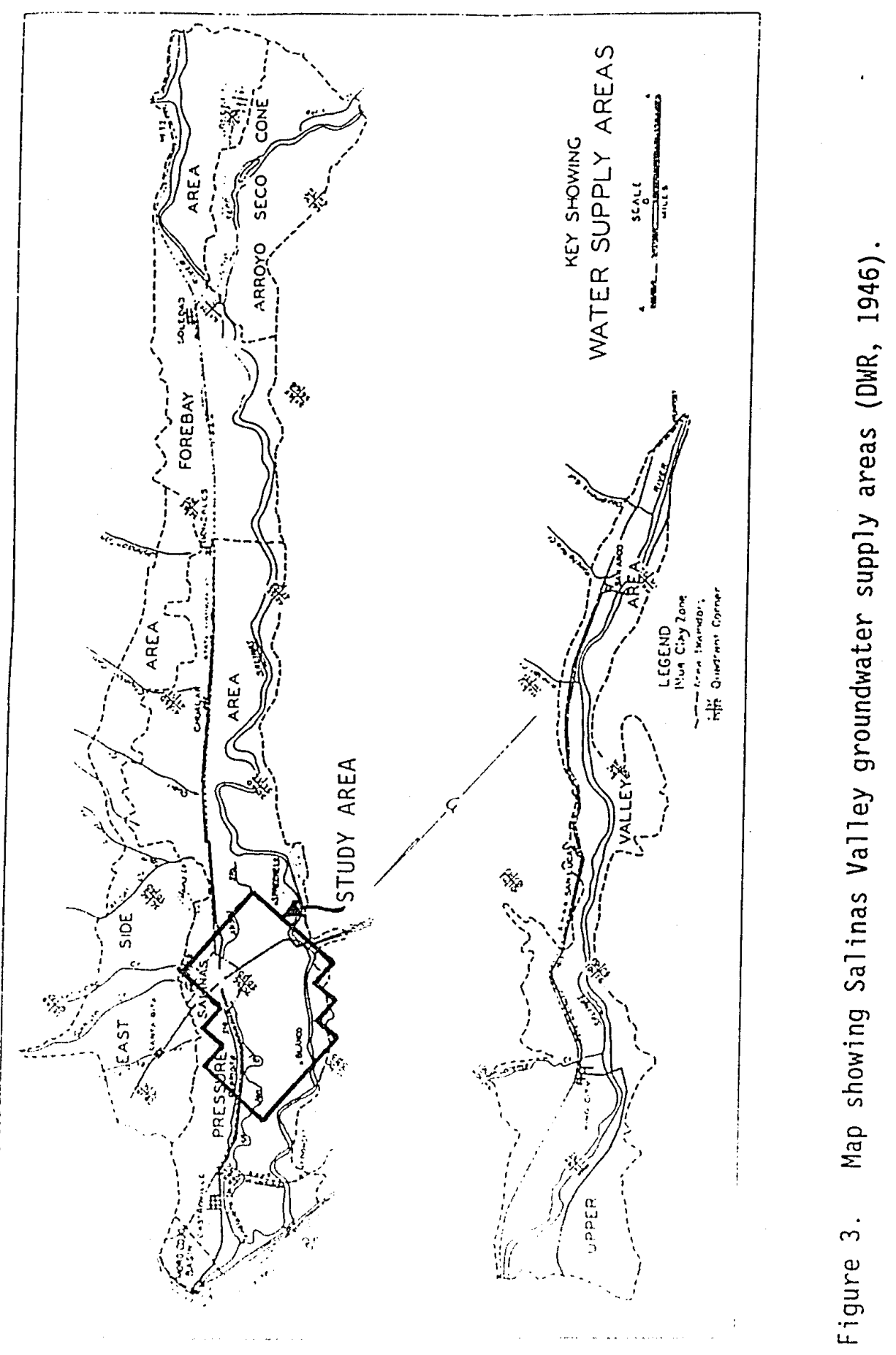


of the Forebay Area. The original divisions were based on the sources of replenishment of ground water.

The principal aquifers of the Pressure Area, the "180-foot" and "400-foot" (120 m) pressure aquifers were identified in the 1946 investigation. The aquifer names generally reflect their respective average depths of occurrence below ground surface. A subsequent investigation concluded (1) that the ground water in the "180-foot" pressure aquifer was recharged from the Forebay Area and (2) the exact source of recharge for the "400-foot" pressure aquifer was unknown (CDWR, 1946) .

In 1960 the MCWRA investigated the geologic conditions of the Salinas Valley from Greenfield to the mouth of the Salinas River (1) to define the lateral extent of the clay cap overlying the "180-foot" pressure aquifer and all major holes in the clay cap that would allow surface water to reach the "180-foot" pressure aquifer, (2) to define the lateral extent of the clay aquiclude between the "180-foot" and "400-foot" pressure aquifer or define the recharge area for the "400foot" pressure aquifer, and (3) to provide a more definite description and definition of the East Side Area to establish a logical East Side boundary (MCFCWCD, 1960). They concluded the following:

The Pressure 180 and Pressure 400 aquifers are both complex zones of interconnected permeable and semi-permeable strata. Neither zone is a well defined uniform aquifer with a consistent slope beneath a well defined, uniform clay barrier from the Forebay to the coast. However, the clay barrier between the Pressure 180 aquifer and Pressure 400 aquifer appears to be continuous from Salinas to the ocean except for possible breaks in the barrier under the Salinas 
River channel near Blanco and under the old Salinas River channel near the coast.

The depths of the two aquifer zones vary greatly and are not necessarily at the 180 and 400 foot depths implied by their designations...

The Pressure 180 aquifer clay cap south of Salinas has several large breaks where surface recharge or contamination is possible.

The report includes five longitudinal geologic sections along the length of the Salinas Valley parallel to the river, sixteen geologic sections perpendicular to the valley axis, and fourteen geologic sections oblique to the valley axis. The sections were constructed by correlating cable tool well logs and the data were supplemented by rotary well logs where no other information was available.

A comprehensive study of sea water intrusion in the lower Salinas Valley was jointly conducted by the CDWR and MCWRA (CDWR, 1970 and 1973). All available geologic maps of the lower Salinas Valley were compiled into one composite geologic map. The authors combined the geologic maps with 1 ithologic logs and electric logs from water wells and $0 i 1$ wells to correlate the geologic units with their respective hydrologic properties. Six geologic sections depict the subsurface geology. The authors concluded that the "180-foot" and "400-foot" pressure aquifers are "partially discontinuous beds of water-bearing material that contain numerous clay lenses" (CDWR, 1970).

Tinsley (1975) detailed the Quaternary geology of the northern Salinas Valley. He discussed in detail the soil stratigraphy, glacio- 
eustatic sea level changes and sedimentation, alluvial fan morphology, and Pleistocene tectonism of the northern Salinas Valley. 
REGIONAL GEOLOGY

The geology of the central Coast Ranges is indicative of a relatively youthful structural and geomorphic setting. The oldest bedrock assemblages in the Coast Ranges consist of 1) the JurassicCretaceous Franciscan Complex and 2) the Late Paleozoic(?) Sur Series and associated Mesozoic granitic rocks (Greene, 1977). The basement rock is overlain by Tertiary sedimentary rocks consisting predominantly of marine deposits, with interbedded continental rocks (Greene, 1977). The Tertiary rocks near Salinas include the Miocene marine Monterey Formation, which consists of bedded shale, diatomite, and sandstone and is thought to be non-water-bearing. The Monterey Formation is unconformably overlain by unconsolidated deposits of Tertiary and younger age. Beneath the City of Salinas, the top of the Monterey Formation lies below a depth of $1,050 \mathrm{ft}(320 \mathrm{~m})$, the bottom of the deepest we11 (CDWR, 1970).

Unconsolidated deposits of the Salinas Valley range from Pliocene to Holocene in age. The Pliocene Purisima Formation consists of poorly indurated gravel, sand, silt, and silty clay. The bottom of the formation is marine and contains saline water, and the upper portion of the formation is continental and contains good quality water (CDWR, 1970). The Plio-Pleistocene Paso Robles Formation consists of poorly bedded deposits of sand, gravel, clay, tuff, and calcareous material (CDWR, 1969). The Pleistocene Aromas red sands, as defined by Dupré (1975), are a heterogeneous mixture of cross-stratified sand, silt and gravel deposited as a series of fluvial and alluvial fan systems 
interbedded with eolian sediment consisting of partly oxidized and indurated, moderately well sorted, quartzose sand with interbedded clay and grave1 layers (Dupré, 1975).

Quaternary older flood-plain and younger flood-plain deposits on the floor of the Salinas Valley were formed by overwash of the Salinas River and consist of unconsolidated, predominantly fine-grained, heterogeneous deposits of sand and silt, commonly including thin layers of clay. The lower part of the older flood-plain deposits is gravelly (Dupré and Tinsley, 1980). Quaternary basin deposits consist of unconsolidated plastic clay and silty clay containing organic matter, and these locally contain thin, interbedded layers of silt and silty sand. The basin deposits accumulated in a variety of environments including estuaries, lagoons, tidal flats, marsh-filled sloughs, flood basins, and lakes (Dupré and Tinsley, 1980). The geology of the study area is shown in Figure 4.

\section{Depositional History}

The sediments of the northern Salinas Valley have been deposited during a series of marine transgressions and regressions caused by eustatic sea level changes throughout the late Tertiary and Quaternary periods.

The lowest known stand of global sea level occurred during the late 01 igocene when the probable fall in sea level is believed to have been considerably more than 200 in (Vail and others, 1977). This resulted in the removal of sediments and exposure of the granitic 


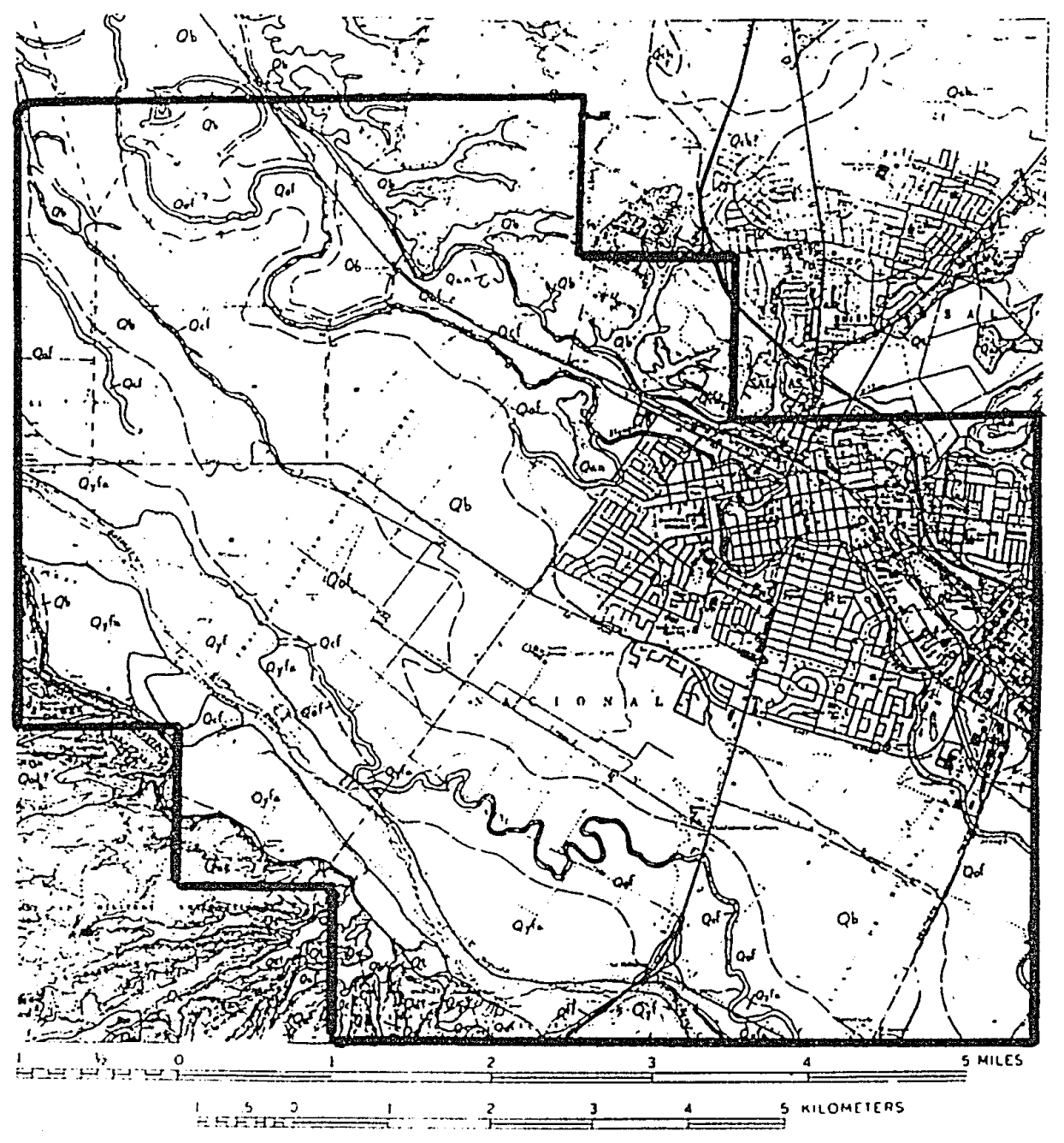

Qb - Basin deposits

Qyfa - Younger flood-plain deposits

Qof - Older flood-plain deposits

Qcf - Channel-fill deposits

Qfl - artificial fill

Qch? Alluvial fan deposits of Chular

Qt Terrace deposits, undifferented

Qan - Terrace deposits of Antioch

Qan, Youngest Antioch terrace surface apProximate MEAS

Qae Eolian deposits

Figure 4. Ceologic map of Quaternary deposits in the study area (Dupré and Tinsley, 1980). 
basement rocks in the Salinas Valley (Greene and Clarke, 1979). This erosional surface is identified from well data in the Salinas Valley by Martin and Emery (1967), who named it the "Elkhorn erosion surface."

In early middle Miocene time, a regional transgression led to the deposition of marine sediment of the Monterey Formation throughout the Monterey Bay region (Greene and Clarke, 1979). These deposits were partially eroded during the middle to late Miocene, when much of the northern Monterey Bay region was emergent. The Pliocene Purisima Formation was subsequently unconformably deposited upon the Monterey Formation.

The Salinas River probably originated during the Pliocene when marine sediments of the Purisima Formation graded into continental sediments. Dupré (1990) stated that the Salinas River has occupied its present course for at least $3.9 \mathrm{~m} . \mathrm{y}$. , as evidenced by the fluvial deposits of the Paso Robles Formation. The Paso Robles Formation and the overlying Aromas red sands are thought to be, in part, lateral equivalents (Dupré, 1990).

The central Monterey Bay region is thought to have been a stable to subsiding depocenter throughout the Quaternary (Dupré, 1975, 1990; Dupré and others, 1980). As such, the northern Salinas Valley provides the most continuous sequence of Quaternary sediments and depositional history in the Monterey Bay region.

In the Watsonville region, Dupré (1975) reported at least eleven depositional cycles formed during glacio-eustatic fluctuations of sea Tevel during the Quaternary. Dupré (1990) has correlated a Sangamon 
(-118 ka) highstand shoreline (1) with the Watsonville fluvial terrace complexes and (2) with fluvial terraces formed by the Salinas River, preserved with their associated alluvial fans, near the City of Salinas. Mid-Wisconsin (40-45 ka or greater) deltaic sediments were deposited by the Salinas River offshore on the southern Morterey Bay shelf during a mid-Wisconsin stillstand and/or initial part of the mid-Wisconsin regression (Chin, 1984). Chin (1984) reported that a mid-Wisconsin transgression drowned the lower coastal valley of the Salinas River and formed an estuarine embayment, which was subsequently filled by the Salinas River sometime near stillstand between the mid-Wisconsin interglacial period and the start of the late-Wisconsin glacial period $(30 \mathrm{ka})$.

Glacio-eustatic sea level continued to drop during the lateWisconsin regression as continental glaciation reached a maximum (Chin, 1984). The Salinas River became entrenched during this last pleniglacial lowstand of sea level approximately 18-20 ka, forming incised valleys as deep as $280 \mathrm{ft}(85 \mathrm{~m})$ at the present-day coastline (Dupré, 1975; Tinsley, 1975; Chin, 1984; Schwartz and others, 1986).

The subsequent rise in sea level, the Holocene transgression, was accompanied by deposition of gravel-rich sediment in the lower parts of the valley-fill, followed by flooding of the coastal portions of the valley and deposition of estuarine mud, locally up to $98 \mathrm{ft}(30 \mathrm{~m})$ thick and extending up to $22 \mathrm{mi}(35 \mathrm{~km})$ inland of the present shoreline (Dupré, 1990). This transgression, which occurred mainly during the 
Holocene, may have started as early as $20 \mathrm{ka}$. The transgression was mostly complete by $5 \mathrm{ka}$ (Chin, 1984).

The upper part of the valley-fill consists mainly of stream deposits and flood-basin clays. Aggradation of the trunk streams dammed many of the smaller, entrenched tributaries, which resulted in the deposition of thick sequences of lacustrine and flood-basin clay, up to $82 \mathrm{ft}(25 \mathrm{~m})$ thick, which underlie many of the sloughs adjacent to the main course of the Salinas River (Dupré, 1990). Dupré (1990) stated that a climatically induced entrenchment of the Salinas River resulted in the formation of a Holocene fluvial terrace 16 to $39 \mathrm{ft}$ (5 to $12 \mathrm{~m}$ ) above the present floodplain, graded to the present highstand of sea leve1. He suggested that the entrenchment may record a period of increased precipitation sometime before 1850 .

A sample of wood from a well located $15 \mathrm{~m}$ below ground surface in Section 8, T15S R3E, provided a ${ }^{14} \mathrm{C}$ age of $2880 \pm 160$ years BP (Tinsley, 1975). The elevation of the wood sample is approximately $+5 \mathrm{ft}(2 \mathrm{~m})$. The sample provides an approximate age for the fine-grained sediments found at this location and at this elevation.

Tinsley (1975) provided an interpretation of the local geologic history from the Leonardini well, located near the Highway 1-Salinas River crossing (TI4S R2E Section 7) about 4 miles west-northwest from the study area. The lithologic units in the Leonardini well correlate well with the lithologic units in the study area. Based on foraminiferal assemblages, he determined that the uppermost $25 \mathrm{ft}(8 \mathrm{~m})$ are composed of fluvial sediments of the present flood plain of the 
Salinas River. Blue clay identified on the well $\log$ occurred from 25 to $150 \mathrm{ft}(8$ to $45 \mathrm{~m}$ ) with gravel deposits streaked with blue clay located from 75 to $100 \mathrm{ft}(23$ to $30 \mathrm{~m})$ and 125 to $150 \mathrm{ft}(38$ to $45 \mathrm{~m})$ below ground surface. Based on the spectrum of benthic foraminifera identified in the blue clays, the base of the Holocene marine transgression was marked about $150 \mathrm{ft}(45 \mathrm{~m})$ below mean sea level. The species of foraminifera and diatoms indicated that the blue clay was deposited in quiet water conditions in a tidal marsh. The origin of the gravel deposits could be interpreted as flood events or as minor regressions allowing downcutting of stream channels and subsequent filling with fluvial deposits. From samples collected at depths of 250 to $300 \mathrm{ft}(76$ to $91 \mathrm{~m})$ and 500 to $550 \mathrm{ft}(152$ to $168 \mathrm{~m})$ in the Leonardini well, Tinsley (1975) speculated that these strata are of marine origin and that marine strata presently situated at elevations significantly below $-100 \mathrm{ft}(-30 \mathrm{~m})$ may indicate pre-Wisconsin episodes of tectonism.

\section{Geologic Structure}

The northwest-trending Salinas Valley is typical of valleys located in the central California coast region. The northern Salinas Valley is a structural low bounded to the southwest by the northwesttrending King City-Reliz fault and to the northeast by the northwesttrending Gabilan Range. The King City-Reliz fault is thought to be a high-angle reverse fault with the south side up (Greene, 1977). Near the study area, a 60-foot-(18-m-) tall bluff marks the southwestern 
study area boundary and is believed to be the location of the King cityReliz fault (Tinsley, 1975). The Salinas River meanders, predominantly northwesterly, along the base of the bluffs. 


\section{HYDROGEOLOGY}

Past geological and hydrogeological investigations of Salinas Valley aquifers have identified a water table aquifer, two water supply aquifers, and a deep aquifer (CDWR, 1946). The water supply aquifers are known locally as the "180-foot" and the "400-foot" pressure aquifers, corresponding to their approximate average depths. The Salinas Valley is primarily an agricultural area, and the "180-foot" and the "400-foot" pressure aquifers provide most of the potable and irrigation water. In the Pressure Area (CDWR, 1946), the "180- and 400foot" aquifers are generally confined between silt and clay aquicludes. Outside the Pressure Area, the aquifers are generally unconfined. The deep aquifer is known locally as the "900-foot" (270 m) pressure aquifer.

\section{Water Table Aquifer}

The water table aquifer exists within the recently deposited sediments from 10 to $75 \mathrm{ft}(3$ to $23 \mathrm{~m}$ ) below the ground surface (CDWR, 1970). These sediments typically have a low to moderate permeability. At the base of these deposits is a zone of Holocene permeable sandy material about $20 \mathrm{ft}(6 \mathrm{~m})$ thick. The base of this unit has been identified by the CDWR (1970) as the contact between the younger and older valley-fill materials, which probably correlate with the younger and older flood-plain deposits of Dupré and Tinsley (1980). 
Sal inas Aquiclude

The "Salinas aquiclude" consists of older valley-fill materials that act to confine the "180-foot" pressure aquifer. This aquiclude generally consists of silt and clay and ranges in thickness from $25 \mathrm{ft}$ $(8 \mathrm{~m})$ near Salinas to more than $100 \mathrm{ft}(30 \mathrm{~m})$ near Castroville (CDWR, 1970).

\section{"180-Foot" Pressure Aquifer}

The "180-foot" pressure aquifer ranges from 50 to $150 \mathrm{ft}$ (15 to $45 \mathrm{~m}$ ) thick. The upper limit lies between 100 and $150 \mathrm{ft}(30$ to $45 \mathrm{~m}$ ) below the ground surface. It is believed by some workers to correlate with the older portions of the valley terraces and the upper Aromas red sands (CDWR, 1970). However, Greene (1970) stated that the 180-foot aquifer occurs within the valley-fill material, where he defines the valley-fill material as all post-Aromas sediments. Tinsley (1975) correlated the "180-foot" pressure aquifer with the Pleistocene to Holocene deltaic deposits of Greene (1970). Dupré and Tinsley (1980) correlated the "180-foot" pressure aquifer with the lower gravelly portion of the older flood-plain deposits.

\section{Intermediate Aquiclude}

The sediments that separate the "180-foot" pressure aquifer from the "400-foot" pressure aquifer consist of a zone of discontinuous aquifers and aquicludes (CDWR, 1970) composed of sands and clays. These aquifers and aquicludes range from 10 to $70 \mathrm{ft}(3$ to $21 \mathrm{~m})$ thick and are 
located at an average depth of $270 \mathrm{ft}(82 \mathrm{~m})$ below the ground surface (CDWR, 1970).

\section{"400-Foot" Pressure Aquifer}

The "400-foot" pressure aquifer consists in some places of a single, 200-foot- $(60-\mathrm{m}-)$ thick permeable unit and in other places of several different permeable units separated by clay units. These units pinch and swell and are thought to interfinger with the low-lying beds of the "180-foot." pressure aquifer (CDWR, 1970). The "400-foot" pressure aquifer is thought to correlate with the Plio-Pleistocene lower Aromas red sands and the upper Paso Robles Formation (CDWR, 1970; Greene, 1970; Tinsley, 1975).

\section{Lower Aquiclude}

The aquiclude that underies the "400-foot" pressure aquifer is a discontinuous clay layer about $50 \mathrm{ft}(15 \mathrm{~m})$ thick (CDWR, 1970). Beneath this is a series of aquifers and aquicludes with individual thicknesses of 20 to $60 \mathrm{ft}(6$ to $18 \mathrm{~m})$ (CDWR, 1970). These sequences probably correlate with the Paso Robles Formation.

\section{Deep Aquifer}

The deep aquifer is located about 800 to $1600 \mathrm{ft}$ (244 to $488 \mathrm{~m}$ ) below ground surface and produces ground waters with relatively high concentrations of sodium and chloride and relatively low concentrations 
of calcium and magnesium (Todd Engineers, 1989). The ground waters probably lie within the Paso Robles and Purisima formations. 


\section{METHOD OF INVESTIGATION}

The investigative methods used consisted of (1) an analysis of the textural conditions at various elevations to characterize the subsurface sediments, (2) an analysis of "Stiff diagrams" to determine the ground water types, (3) an analysis of the spatial relationship of the ground water types using water zonation maps, (4) line plots with linear regressions showing the change in anion and cation concentrations with time, and (5) an analysis of the historic piezometric surface elevation changes using hydrographs and contour plots.

\section{Textural Classification}

Texture contour maps of the study area were produced to evaluate the lateral extent of coarse-grained sediment. If the coarse-grained sediment is vertically continuous then there may exist a pathway for the downward percolation of agricultural return water.

The MCWRA provided access to logs of water wells drilled in the study area between 1948 and 1990. We11 logs contain a field description of material that the driller encountered at various depths during the drilling. After a review of the well logs, only the cable-tool-drilled wells were selected for analysis. The cable-tool method of drilling provides cuttings that are more representative of the drilled material than do rotary or reverse rotary drilling methods. The locations of the 117 wells used in this study are shown on Figure 5. Wells are identified according to their location in the coordinate system for the Subdivision of Public Lands. Adjacent to each well is a number and 


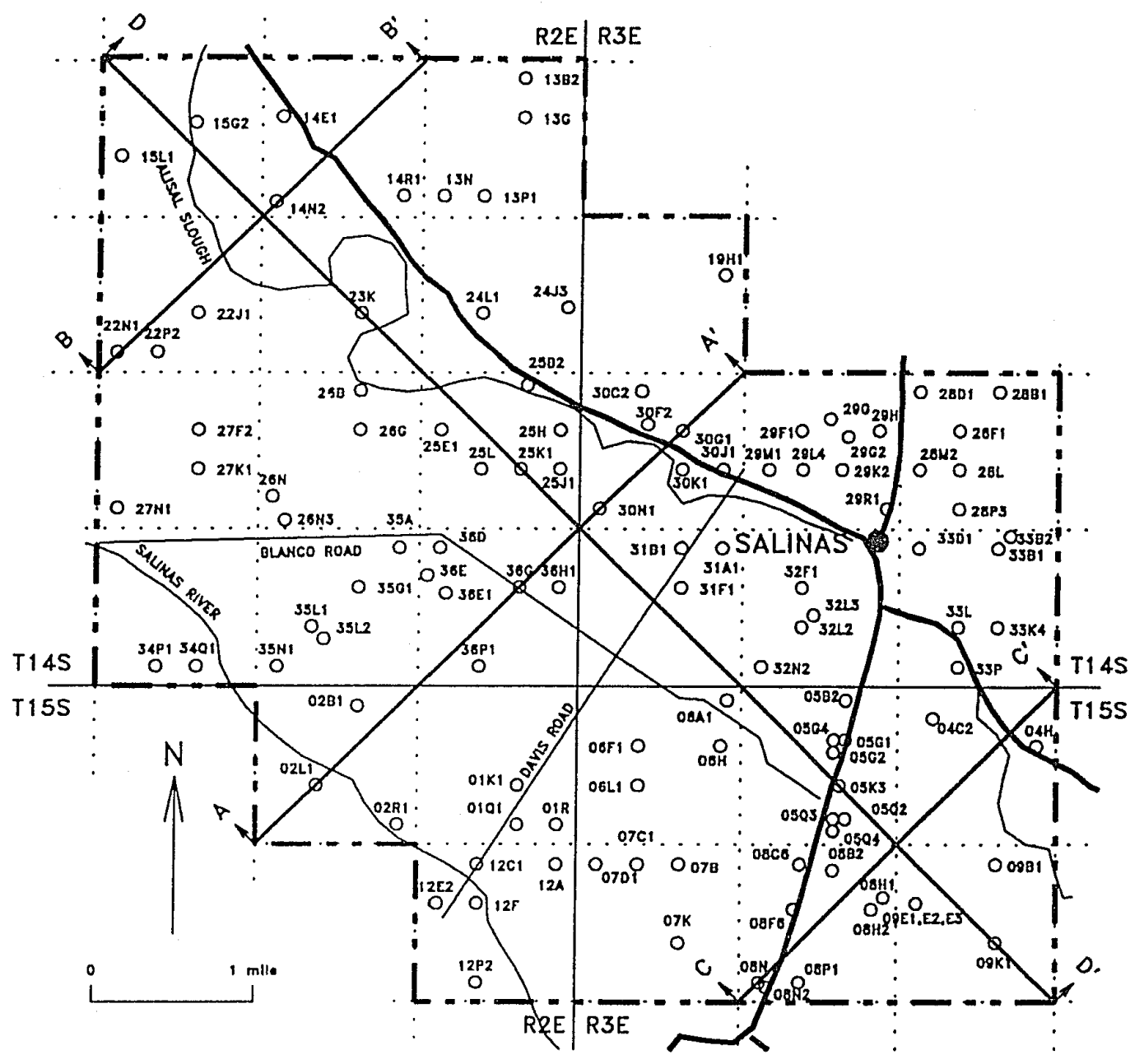

Figure 5. Locations of 117 water wells used to produce texture contour maps of the study area and locations of the geologic cross sections. 
letter that indicates the section and the 40-acre tract in which the well is located. Wells are numbered serially within each tract. For example, 14S/2E-13B2 is the second well to be 1 isted in the $B$ tract of Section 13, Township 14 South, Range 2 East.

The material described in each well log was assumed to represent the 1 ithology within the 40 -acre tract around that we11. The geographic coordinates assigned to most wells (see Fig. 5) are by quarter-mile increments. This was done because several of the well logs used specified the well locations only by tract; the actual map locations of these wells are unknown. Where two wells are located within the same tract, the well locations are offset slightly so that the data could be contoured using the SURFER software program. Well elevations were interpolated from the 7.5-minute Salinas quadrangle topographic map.

An attempt was made to directly correlate different 1 ithologic units between wells, but detailed correlation of lithologic units was impossible because of the significant changes that occur. Therefore, lithologic descriptions on the well logs were used to classify the sediments on the basis of texture.

For this study, texture is defined as the percentage of coarsegrained sediment, interpreted from lithologic descriptions on the well logs. Coarse-grained sediment, for this study, is defined as having greater than 50 percent of sand, grave1, or rock fragments and less than 50 percent of clayey and silty fines. Well logs from the 117 cable-tool drilled wells were used to estimate relative percentages of coarsegrained sediment every $10 \mathrm{ft}$ from elevation $-340 \mathrm{ft}$ to elevation $0 \mathrm{ft}$. 
Table 1 provides a summary of the lithologic descriptions and relative percentage of coarse-grained sediment that was assigned to each 1ithologic type. For example, if from elevation $-300 \mathrm{ft}$ to elevation $-290 \mathrm{ft}$, the 1ithology was described as sandy clay, then the amount of coarse-grained sediment in that 10 -foot interval was 25 percent $(25 \% \mathrm{x}$ $10 \mathrm{ft}$ ). If the 10-foot interval contained $2 \mathrm{ft}$ of clay, $6 \mathrm{ft}$ of sand and gravel, and $2 \mathrm{ft}$ of sand and gravelly clay, then that 10 -foot interval contained 0 percent $(0 \% \times 2 \mathrm{ft})$ coarse-grained sediment in the clay horizon, 60 percent $(100 \% \times 6 \mathrm{ft})$ of coarse-grained sediment from the sand and gravel horizon, and 13 percent $(65 \% \times 2 \mathrm{ft})$ of coarsegrained sediment from the sand and gravelly clay horizon, for a total of 73 percent coarse-grained sediment for the ten-foot interval.

Eighteen texture contour maps, based on percentage of coarsegrained sediment over a 10-foot interval, were constructed every $20 \mathrm{ft}$ from elevation -340 to $0 \mathrm{ft}(104$ to $0 \mathrm{~m})$. The texture contour map at elevation $-340 \mathrm{ft}$ represents an average of coarse-grained sediment from -330 to $-340 \mathrm{ft}$. The contours were produced using the SURFER computer software program. The kriging algorithm was used with a grid spacing of $264 \mathrm{ft}(80 \mathrm{~m})$.

Four geologic cross-sections were constructed to illustrate the subsurface configuration of the bodies of coarse-grained sediment. Locations of the cross-sections are shown on Figure 5 . Cross-sections $A-A^{\prime}, B-B^{\prime}$, and $C-C^{\prime}$ are drawn perpendicular to northwest-trending structural features. Cross-section $D-D^{\prime}$ is drawn parallel to northwest- 
Table 1. Well log Tithologic descriptions and percent of coarsegrained sediment assigned to each lithologic type.

\section{LITHOLOGIC DESCRIPTION}

Adobe/clay/silt/hardpan/hill clay

Clayey silt/silty clay

Hard Formation

Clay with sand/gravel/rocks

Clay, nearly sandstone

Clay and sediment

Clay sediment

Clay, some gravel

Sandy/grave $11 y /$ rocky clay

Gritty clay

Loam

Sandy silt

Sediment

Soil/Top soil

Gravelly clay, streaks of sand

Sandy clay, some gravel/rocks

Sandy soil

Sandy sediment

Sandy clay and some gravel

Cemented gravel and sand

Clay and sand/gravel/rock/hill gravel

Sandy clay to clayey sand

Clay, sand and gravel/rock

Sand and gravelly clay

Sand and sediment

Gravel and layers of clay

Gravel, clay

Seepage

Silty/clayey sand

Mucky sand

Grave1, some clay

Sand and gravel, some clay

Packed sand and some clay

Sand/gravel and clay streaks

Sand/grave 1 and spots/balls of clay

Dirty gravel

Sand and some gravel and clay

Sand with clay

Boulders/rocks/gravel/sand

Gravelly sand/sandy gravel

Mountain gravel

Pack sand

Sand $\mathrm{Hill}$ Formation
PERCENT OF

COARSE SEDIMENT 
trending structures. A fence diagram was constructed to illustrate the three-dimensional distribution of the coarse-grained sediments.

\section{Aquifer Chemistry}

The MCWRA provided water quality analyses for 67 wells tapping the "180-foot" pressure aquifer that were intermittently analyzed by the CDWR and MCWRA from 1953 to 1977. However, the major anions and cations were only measured in 36 of the 67 wells. This study only used the data from those 36 wells with major anion and cation data. The major anions included bicarbonate, chloride, sulfate, and nitrate. The major cations included calcium, magnesium, sodium, and potassium. See Figure 6 for the 67 well locations where water quality analyses were performed. The filled circles on Figure 6 represent the 36 wells that included concentrations of all the major anions and cations. No one well has been analyzed more than 15 times between 1953 to 1977.

"Stiff diagrams" were prepared as part of this study for the 36 wells, and 3 of these wells were selected to be representative of the area. Water zonation maps were prepared to show how the water type changed with time from 1955 to 1977. Linear regressions were completed on 9 of the 36 wells to show changes in the major anion and major cation percentages with time. The locations of the wells where linear regressions were performed are shown on Figure 6 with a filled circle and $\mathrm{a}+$ symbol. Representative Stiff diagrams of $\mathrm{Blanco}$ Drain agricultural return water, sampled in 1965, and of sea water were constructed to compare with the Stiff diagrams constructed for ground 


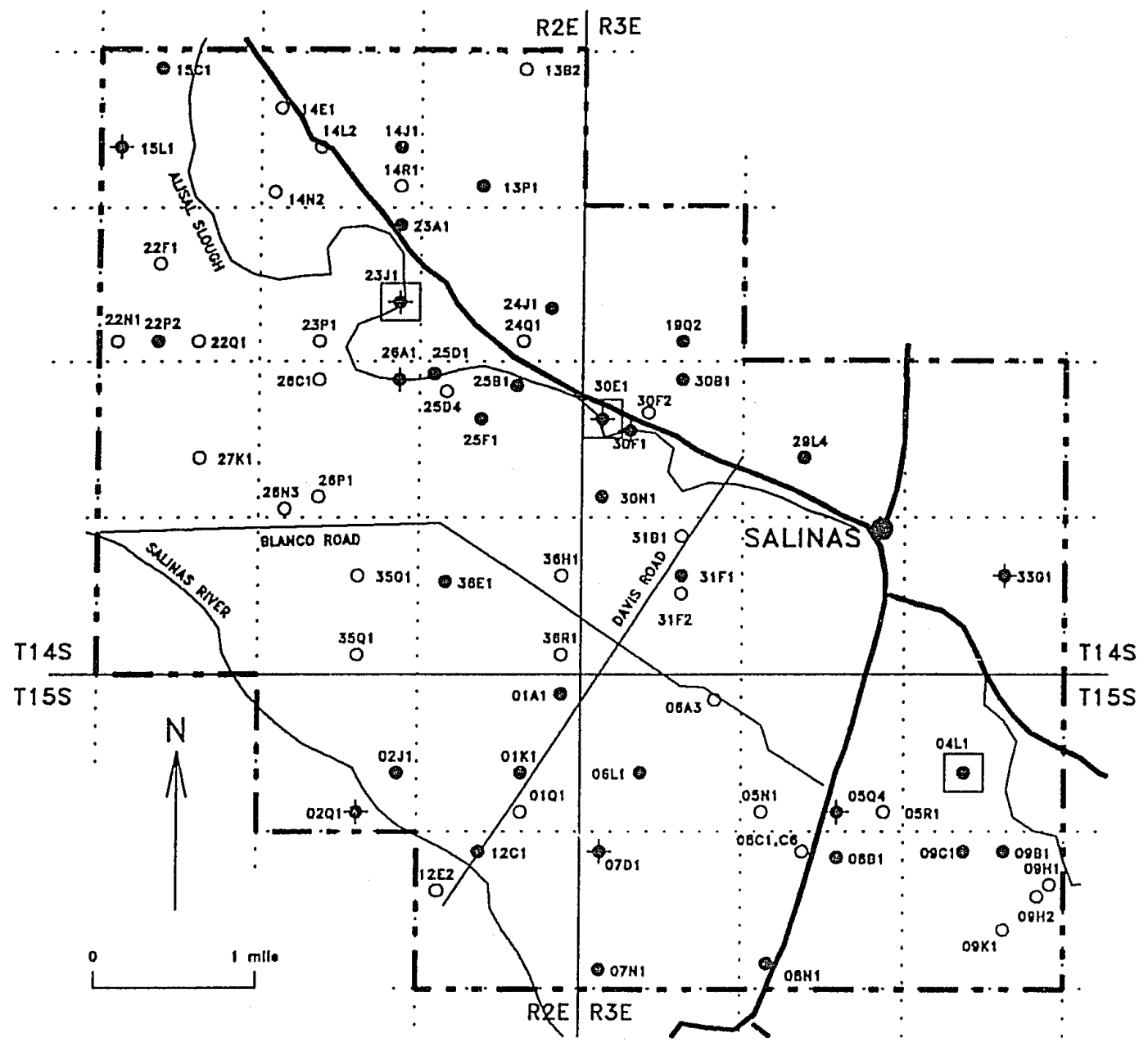

Figure 6. Locations of 67 wells with water quality analyses. Locations of 36 wells with complete major anion and cation data (Appendix I) are shown with a filled circle. Locations of three wells with representative Stiff diagrams are shown with a filled circle enclosed in an open box. Locations of wells used for anion and cation diagrams are shown with a + symbol. 
water in the study area. The locations of the wells where representative Stiff diagrams were constructed are shown as a filled circle enclosed in a box. If the Stiff diagrams have comparable shapes, some conclusions can be drawn about the source of the high-salinity ground water.

\section{Piezometric Surface Elevation}

The MCWRA has been monitoring changes in the well piezometric surface elevation in the study area since 1948. Intermittent piezometric surface elevation records for 30 wells tapping the "180foot" pressure aquifer, provided by the MCWRA, were used to contour the piezometric surface elevations from 1955 to 1990 at 5-year intervals. The contours were produced using the SURFER computer software program. The kriging algorithm was used with a grid spacing of $264 \mathrm{ft}(80 \mathrm{~m})$. See Figure 7 for locations of wells with piezometric surface elevation measurements.

Hydrographs were prepared for wells 14S/2E-13B2, -14E1, -15G1 and $-22 \mathrm{P} 2,14 \mathrm{~S} / 3 \mathrm{E}-30 \mathrm{~N} 1,15 \mathrm{~S} / 2 \mathrm{E}-01 \mathrm{Q} 1$, and 15S/3E-09E3. The seven wel1s span between 16 and 40 years of piezometric surface elevation measurements and generally were measured biannually. The months and years that the piezometric surface elevations are measured are shown on the hydrographs. 


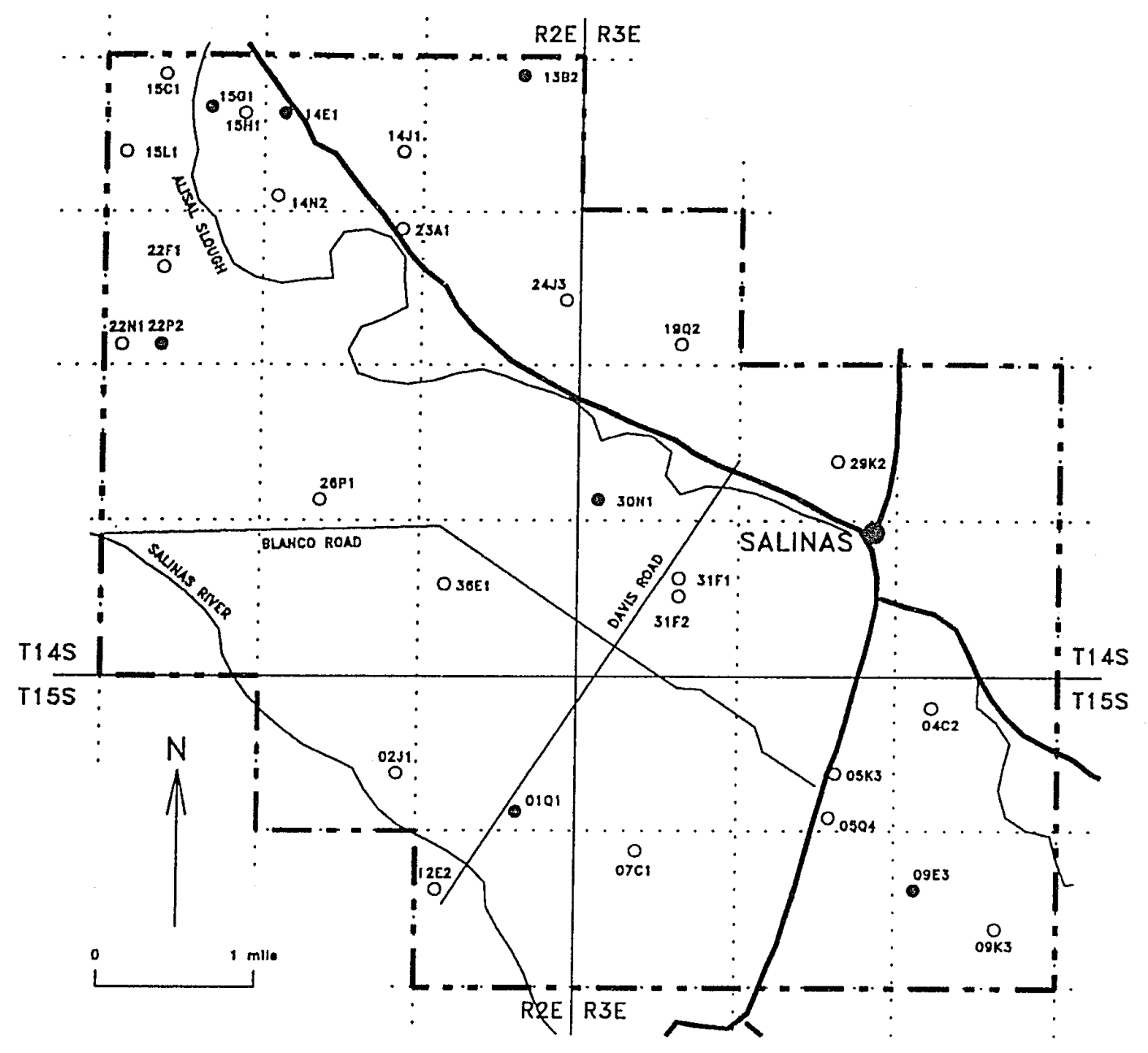

Figure 7. Locations of 30 water wells with historic piezometric surface elevation measurements. Locations of wells for which hydrographs are drawn are shown with a filled circle. 
RESULTS

\section{Textural Classification}

Eighteen texture contour maps (Figs. 8 to 25) were produced. Each map represents an average of coarse-grained sediment found within a 10 foot interval. Contours of the coarse-grained sediment were produced as follows: -340 to $-330 \mathrm{ft},-320$ to $-310 \mathrm{ft},-300$ to $-290 \mathrm{ft},-280$ to $-270 \mathrm{ft},-260$ to $-250 \mathrm{ft},-240$ to $-230 \mathrm{ft},-220$ to $-210 \mathrm{ft},-200$ to $-190 \mathrm{ft},-180$ to $-170 \mathrm{ft},-160$ to $-150 \mathrm{ft},-140$ to $-130 \mathrm{ft},-120$ to $-110 \mathrm{ft},-100$ to $-90 \mathrm{ft},-80$ to $-70 \mathrm{ft},-60$ to $-50 \mathrm{ft},-40$ to $-30 \mathrm{ft}$, -20 to $-10 \mathrm{ft}$, and 0 to $10 \mathrm{ft}$. The texture contour maps are designated by their lowermost elevation. For example, the texture contour map representing the 10 -foot interval from -340 to $-330 \mathrm{ft}$ is designated as $-340 \mathrm{ft}$. The stippled pattern shows regions of more than 75 percent coarse-grained sediment, and the lined pattern shows regions of 50 to 75 percent coarse-grained sediment. Zones consisting of less than 50 percent coarse-grained sediment are blank. Regions where there are insufficient well data are not contoured.

At $-340 \mathrm{ft}$ (Fig. 8), coarse-grained sediment occupies about 60 percent of the study area as a wide northeast- to north-trending swath bounded to the east and west by fine-grained sediments. At $-320 \mathrm{ft}$ (Fig. 9), coarse-grained sediment occupies about 70 percent of the area and is bounded to the west, east, and south by fine-grained sediment. A small, isolated pocket of fine-grained sediment is located in the west-central portion of the study area. At $-300 \mathrm{ft}$ (Fig. 10), coarse-grained sediment occupies the western half of the study area 


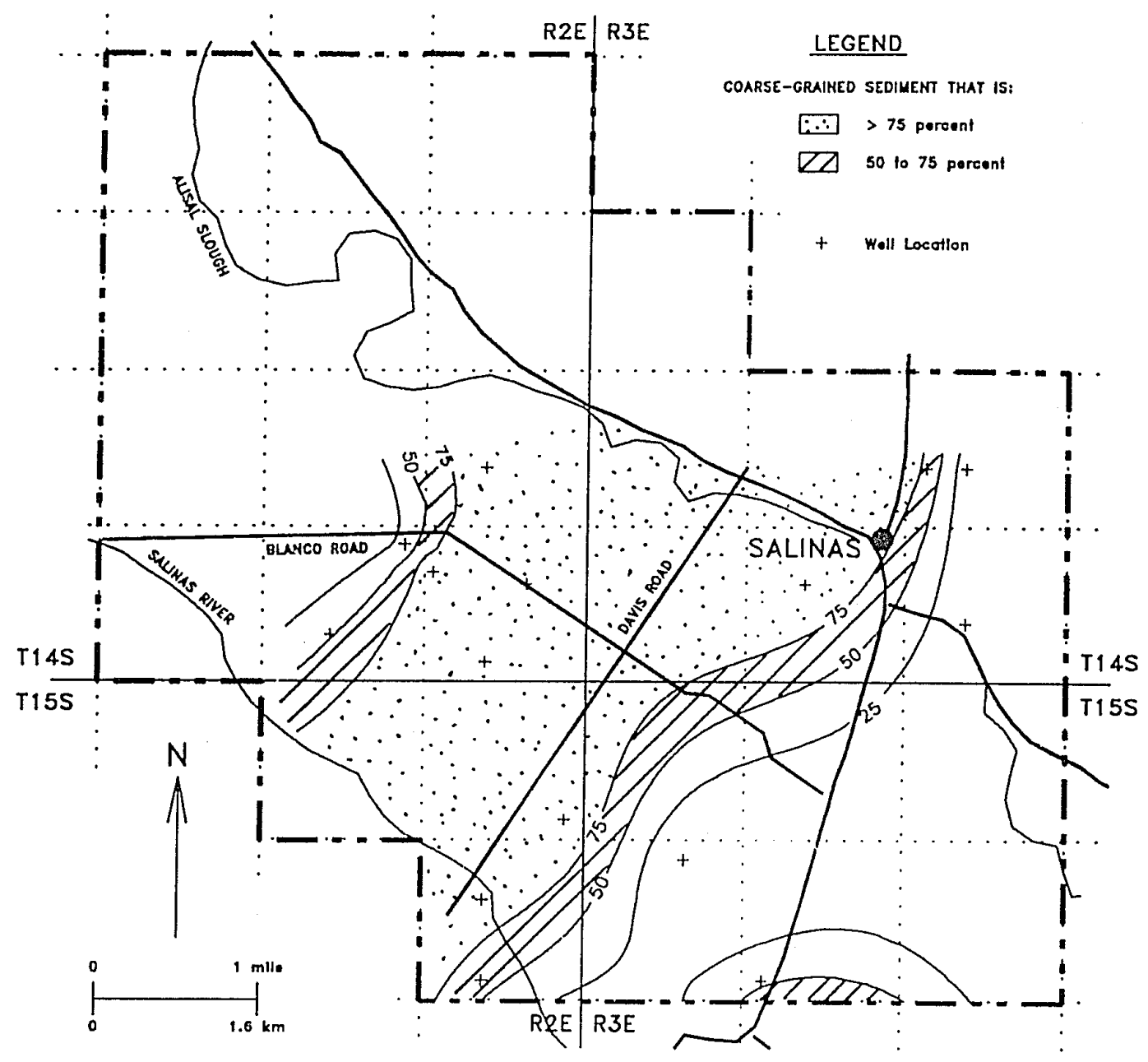

Figure 8. Texture contour map at elevation -340 feet showing the percentage of coarse-grained sediment. 


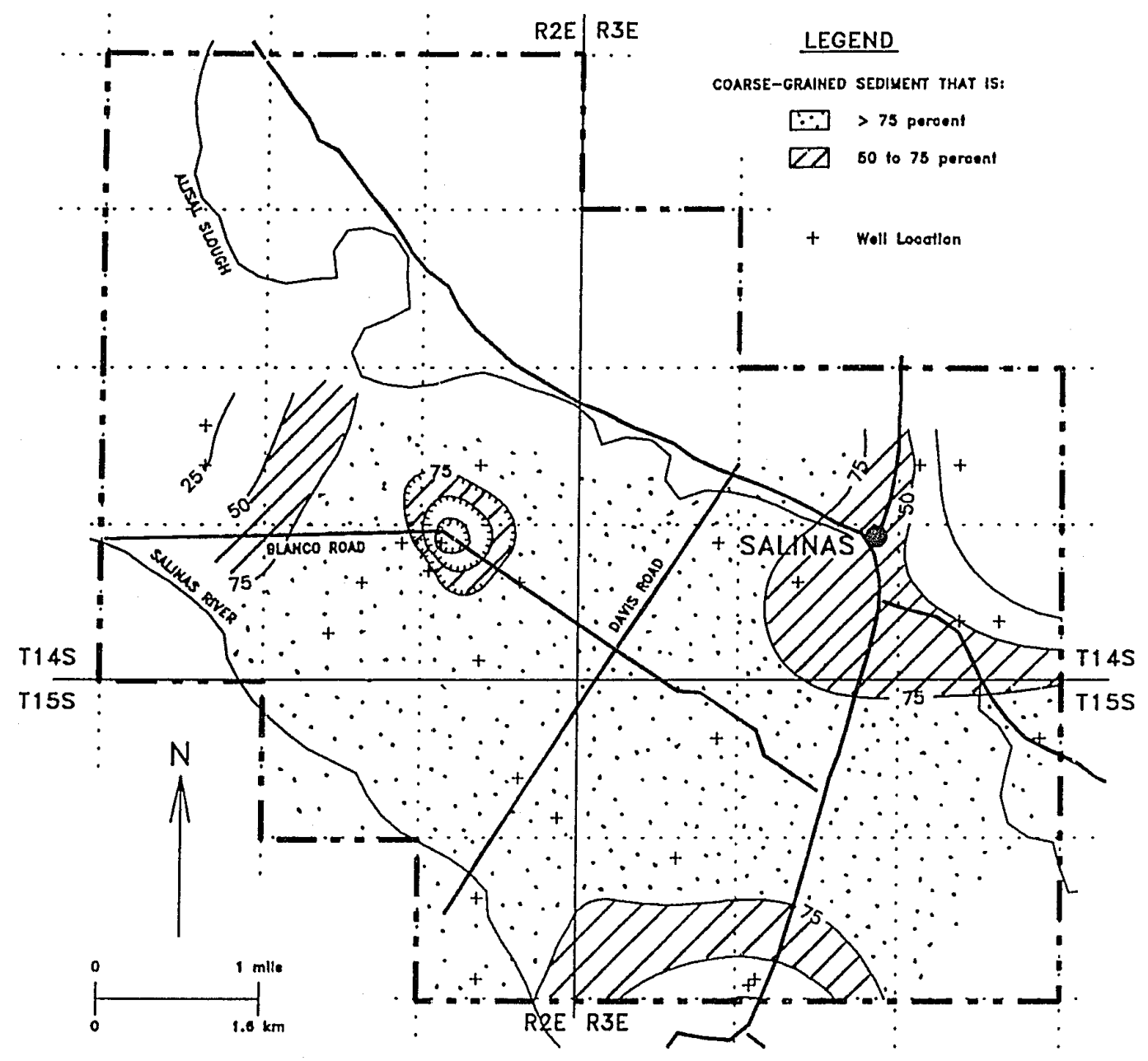

Figure 9. Texture contour map at elevation -320 feet showing the percentage of coarse-grained sediment. 


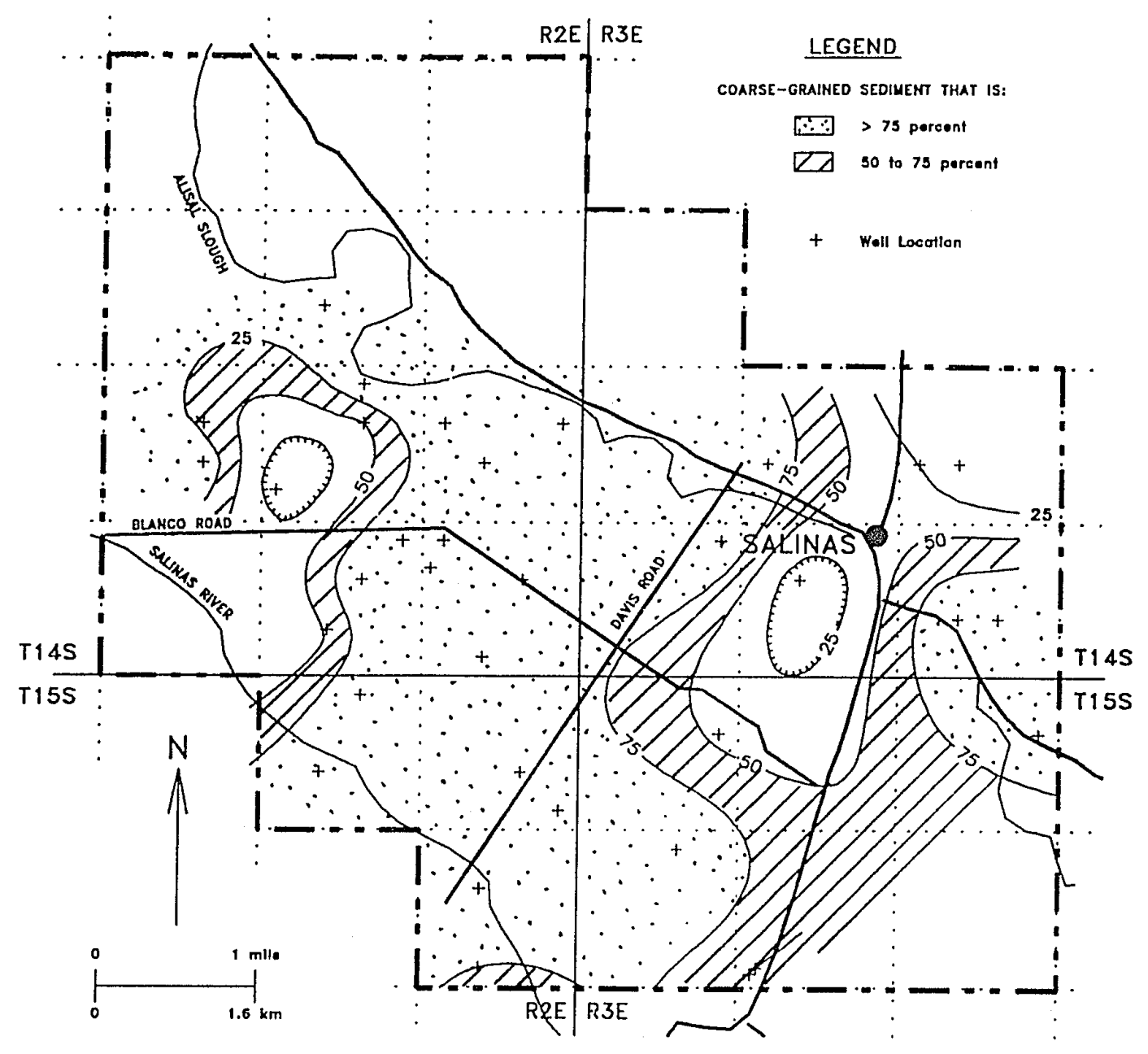

Figure 10. Texture contour map at elevation -300 feet showing the percentage of coarse-grained sediment. 


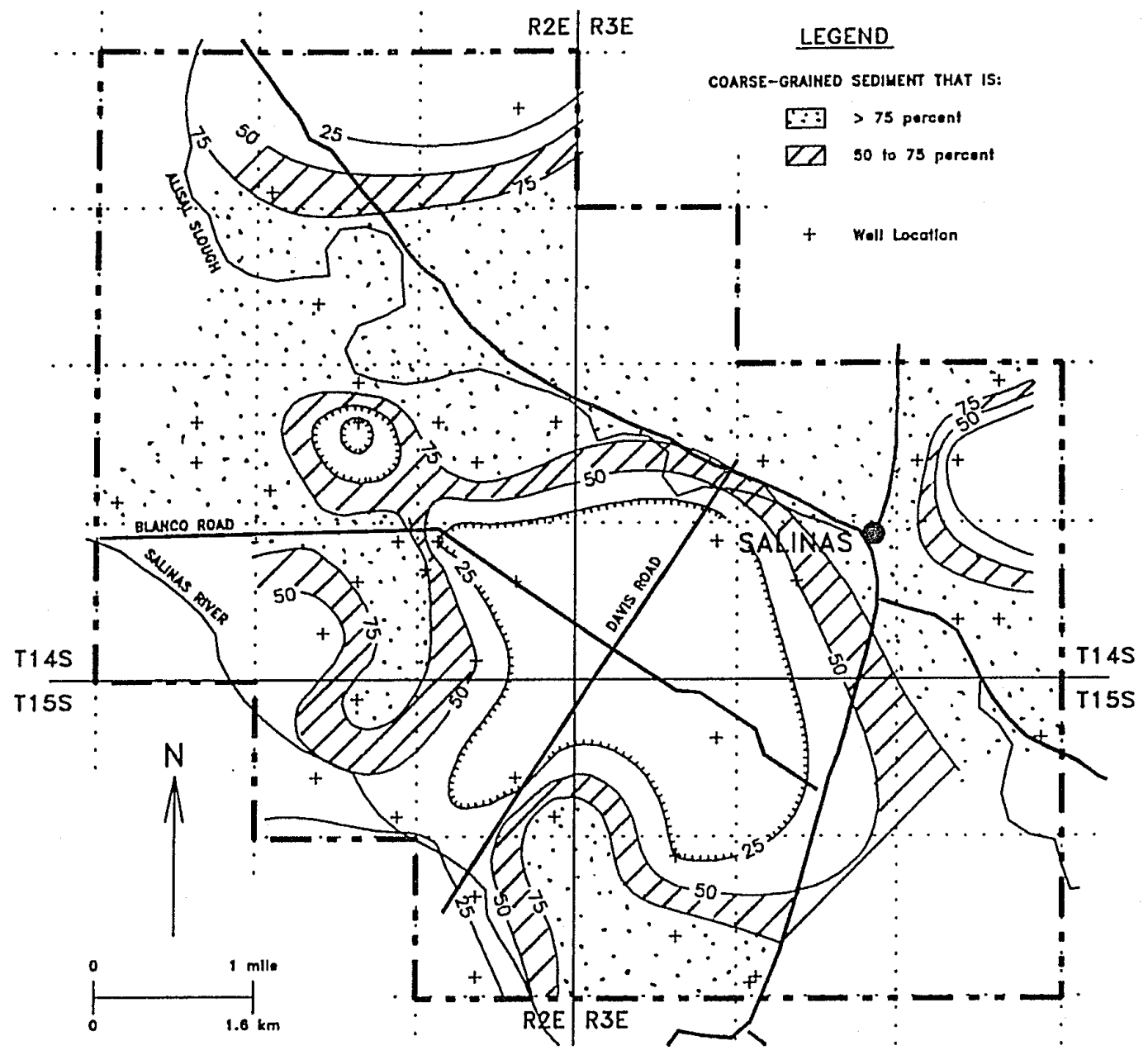

Figure 11. Texture contour map at elevation -280 feet showing the percentage of coarse-grained sediment. 


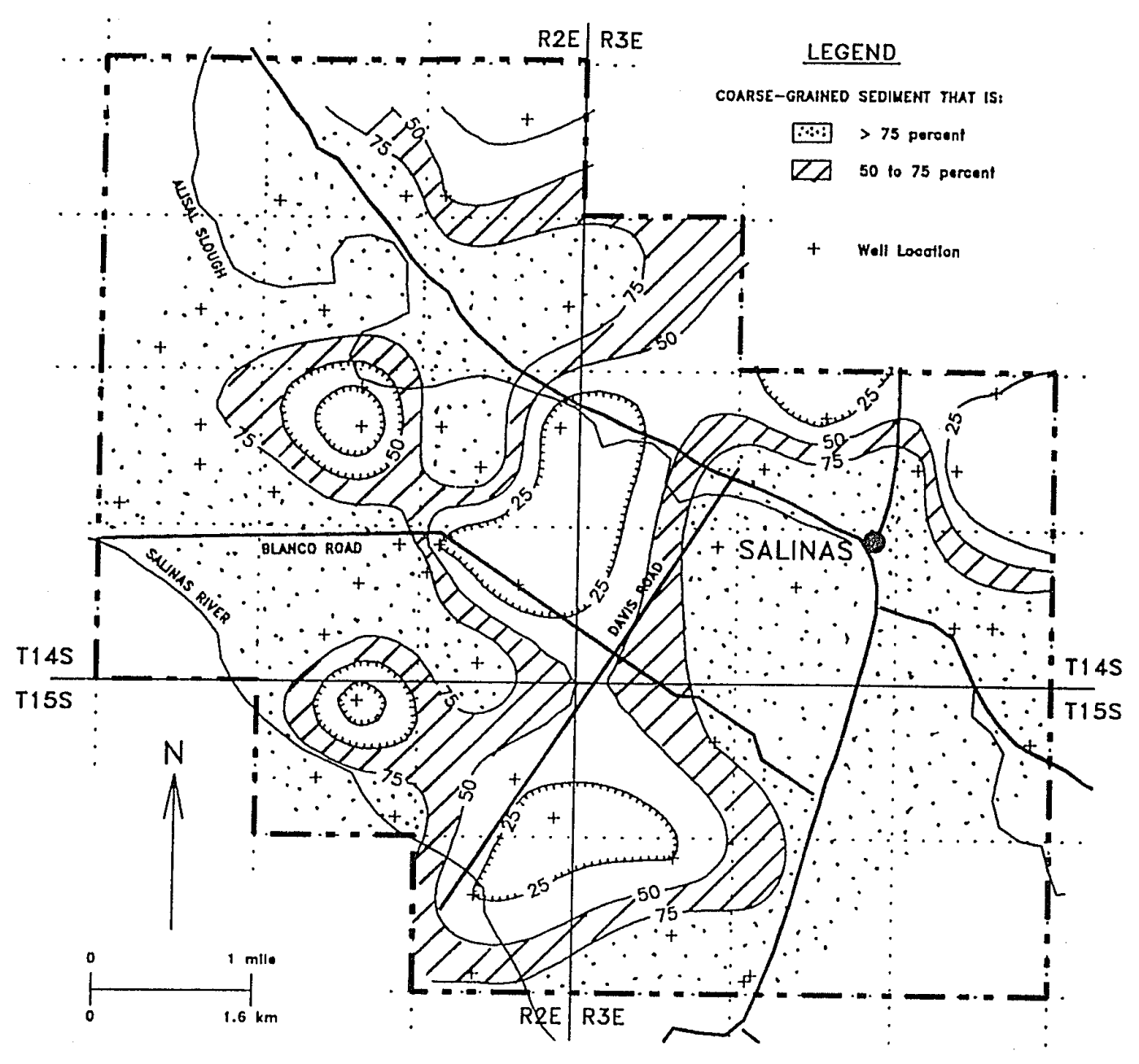

Figure 12. Texture contour map at elevation -260 feet showing the percentage of coarse-grained sediment. 


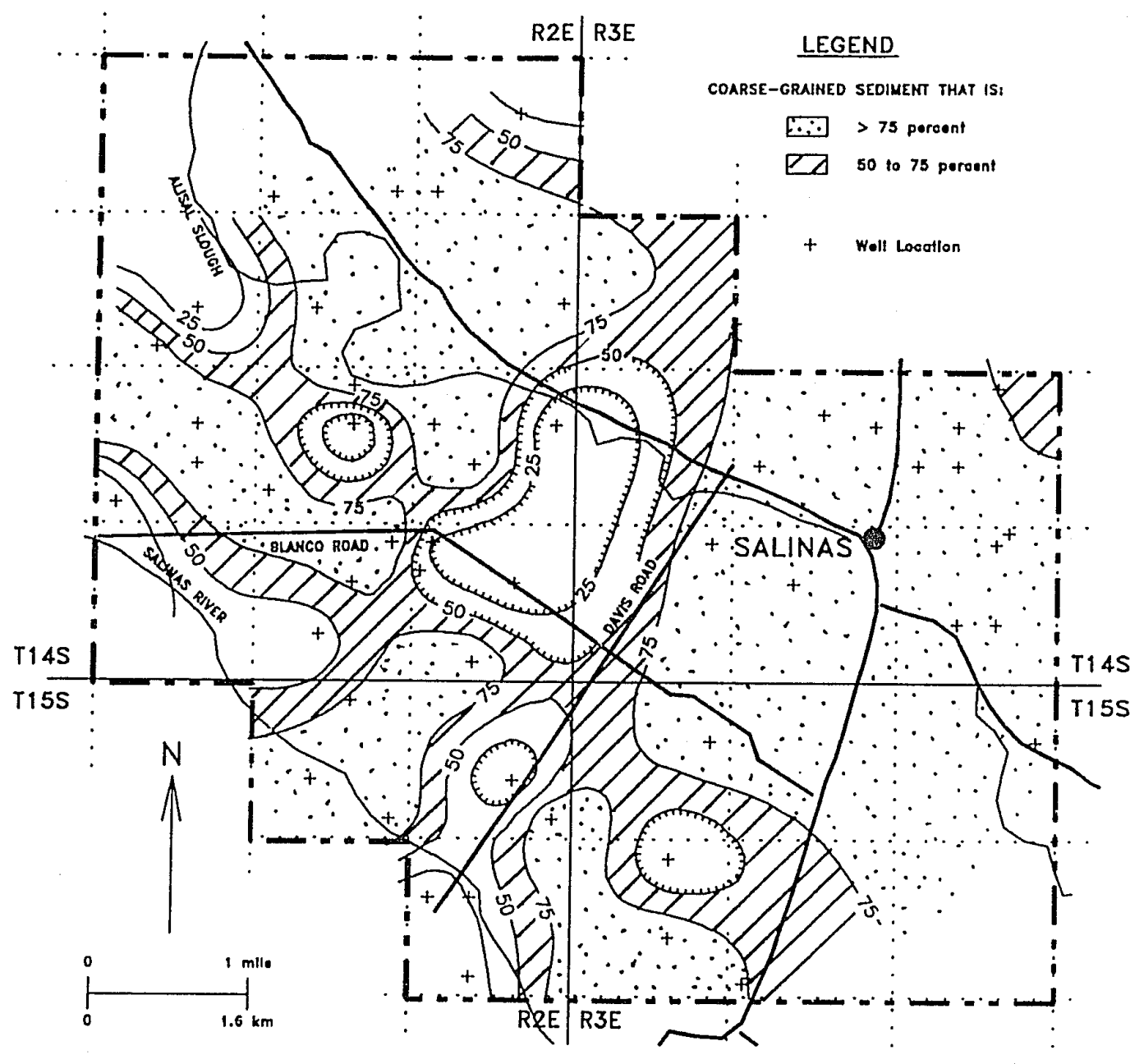

Figure 13. Texture contour map at elevation -240 feet showing the percentage of coarse-grained sediment. 


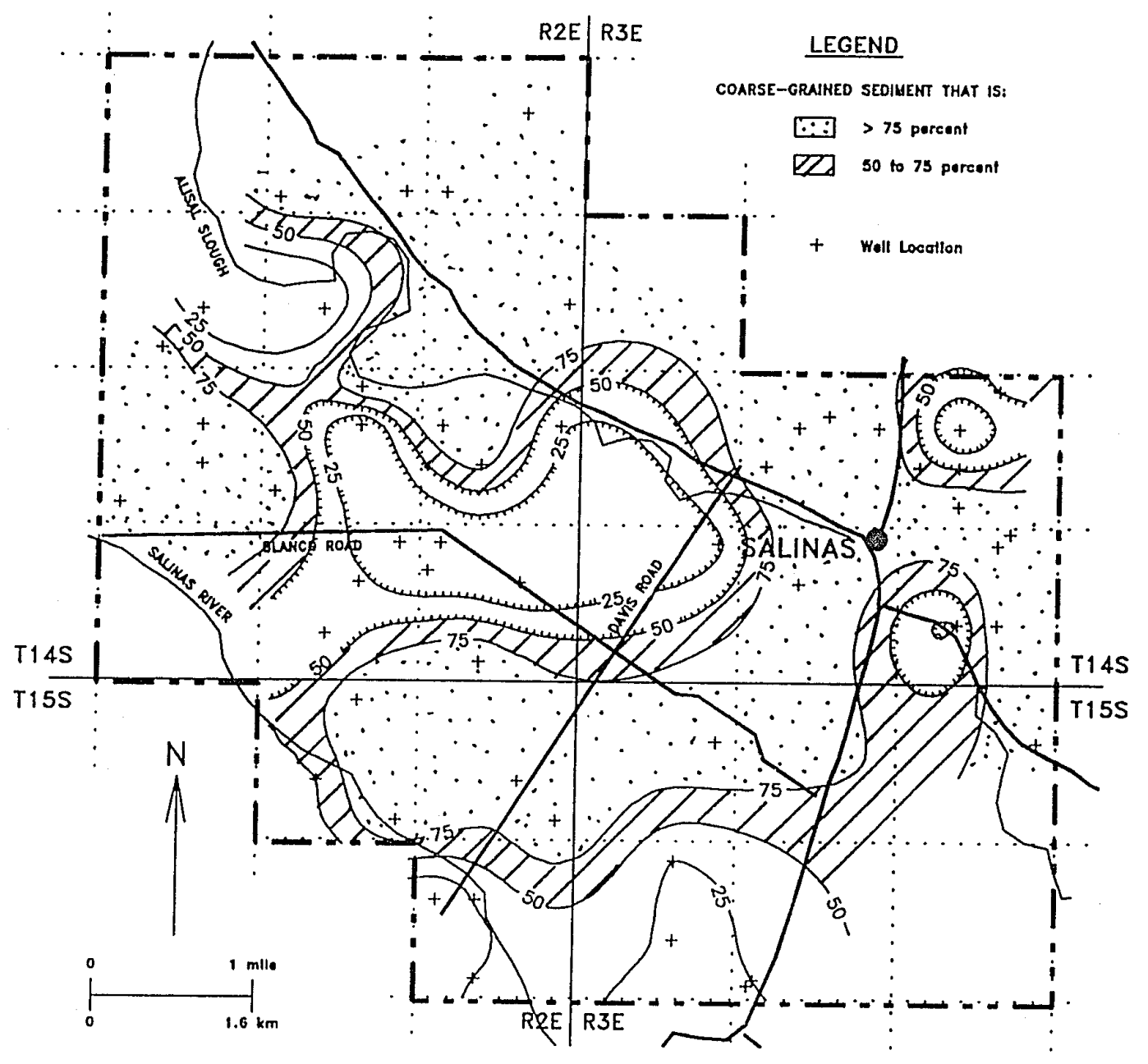

Figure 14. Texture contour map at elevation -220 feet showing the percentage of coarse-grained sediment. 


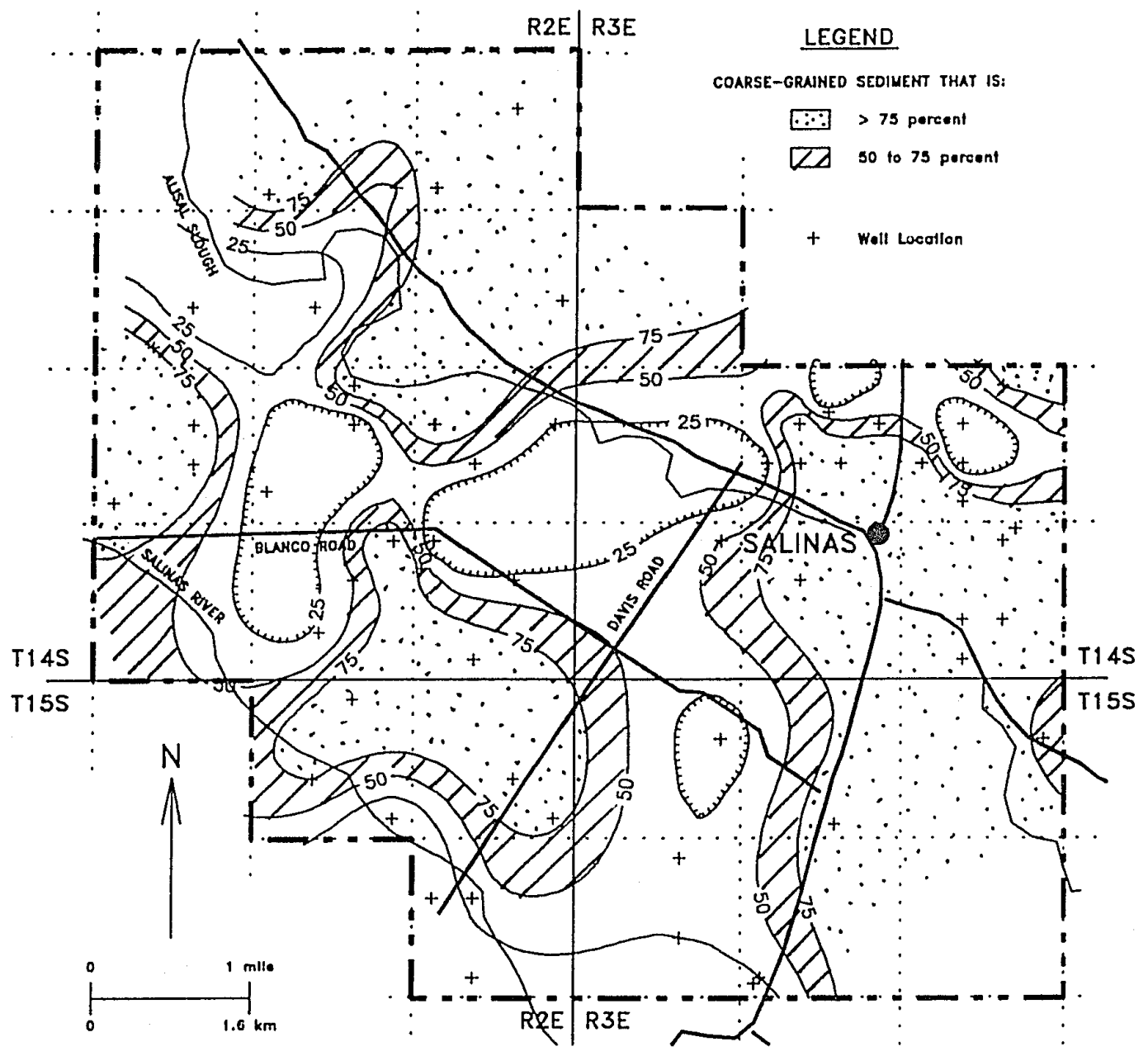

Figure 15. Texture contour map at elevation -200 feet showing the percentage of coarse-grained sediment. 


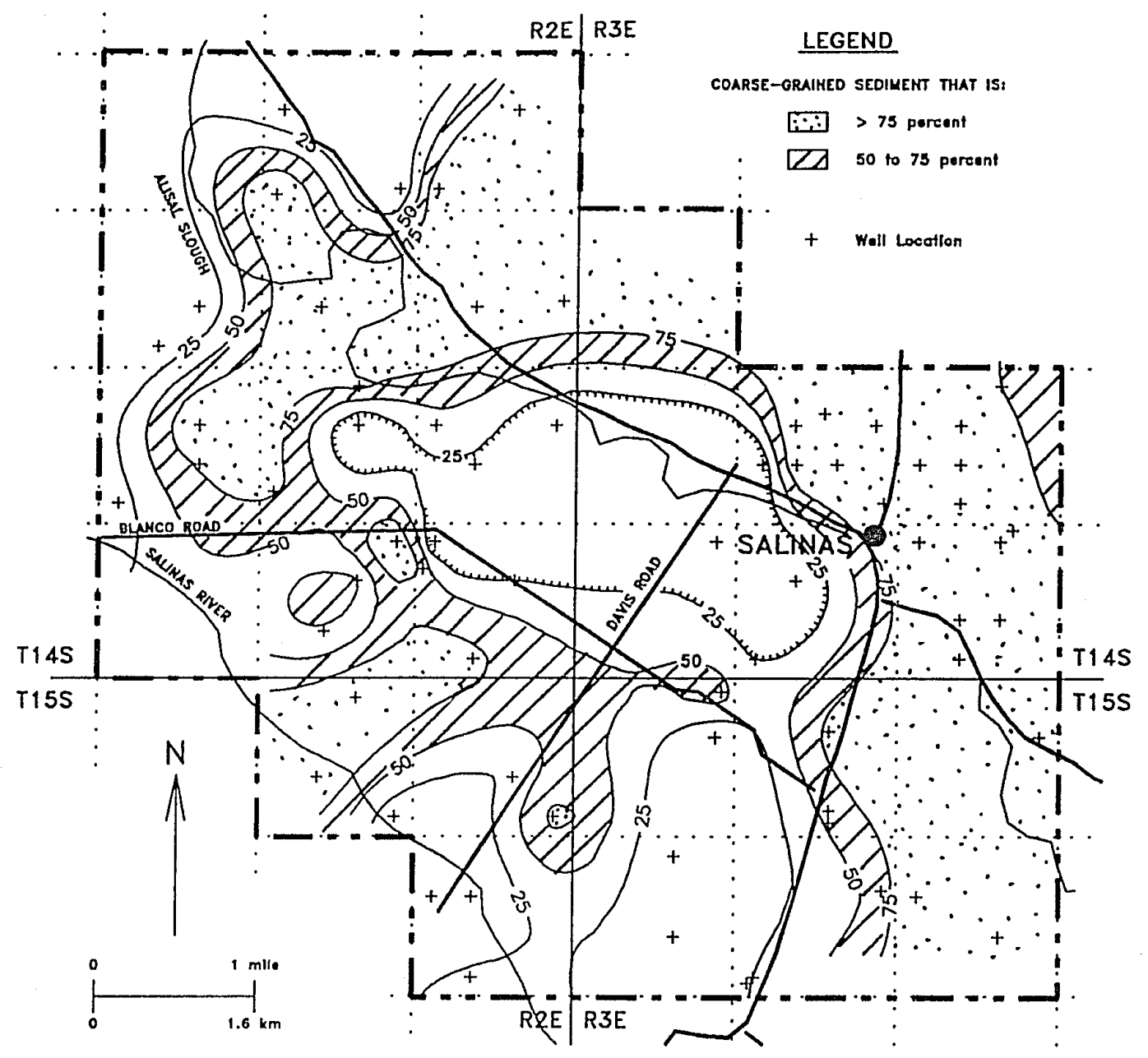

Figure 16. Texture contour map at elevation -180 feet showing the percentage of coarse-grained sediment. 


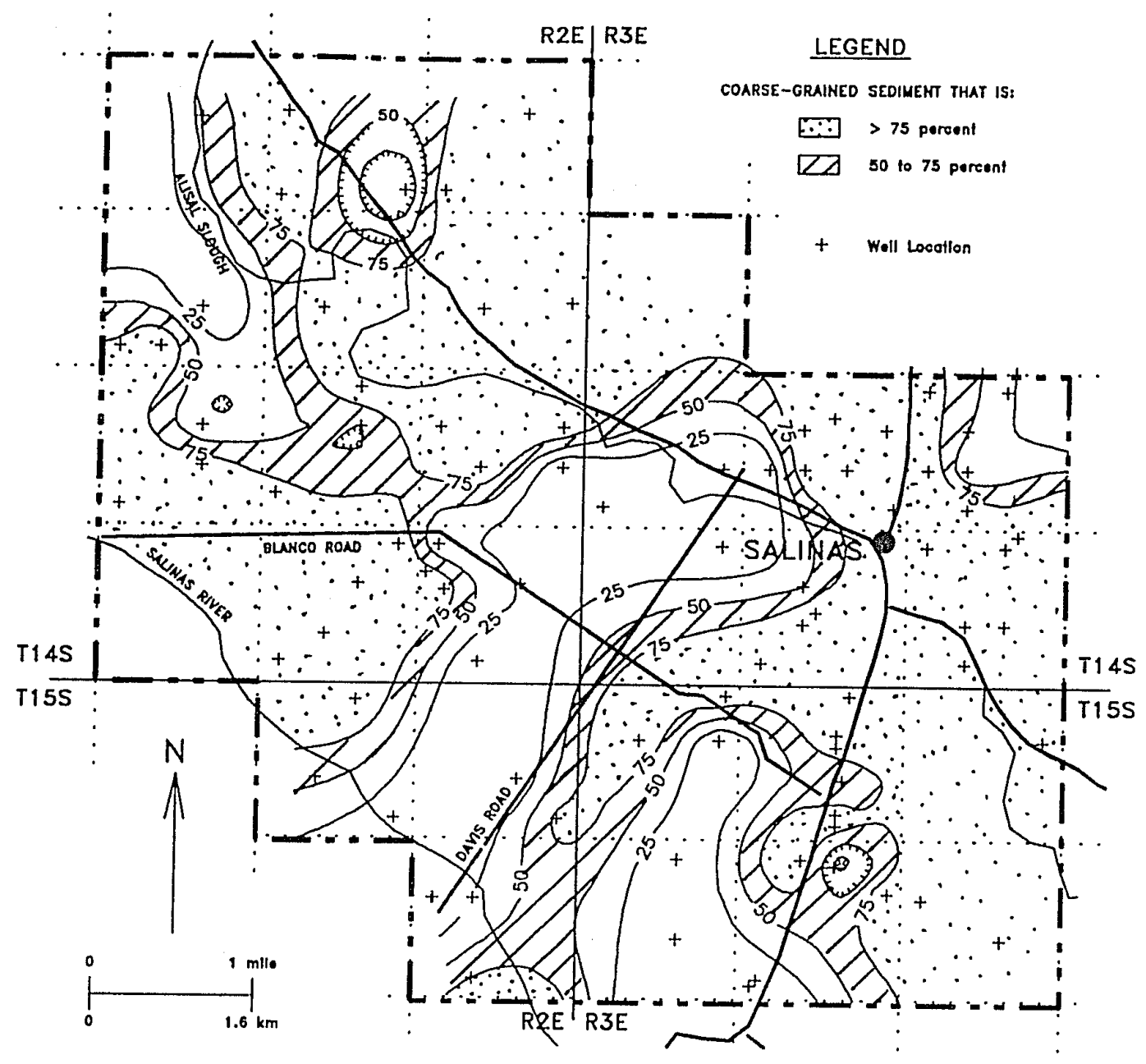

Figure 17. Texture contour map at elevation -160 feet showing the percentage of coarse-grained sediment. 


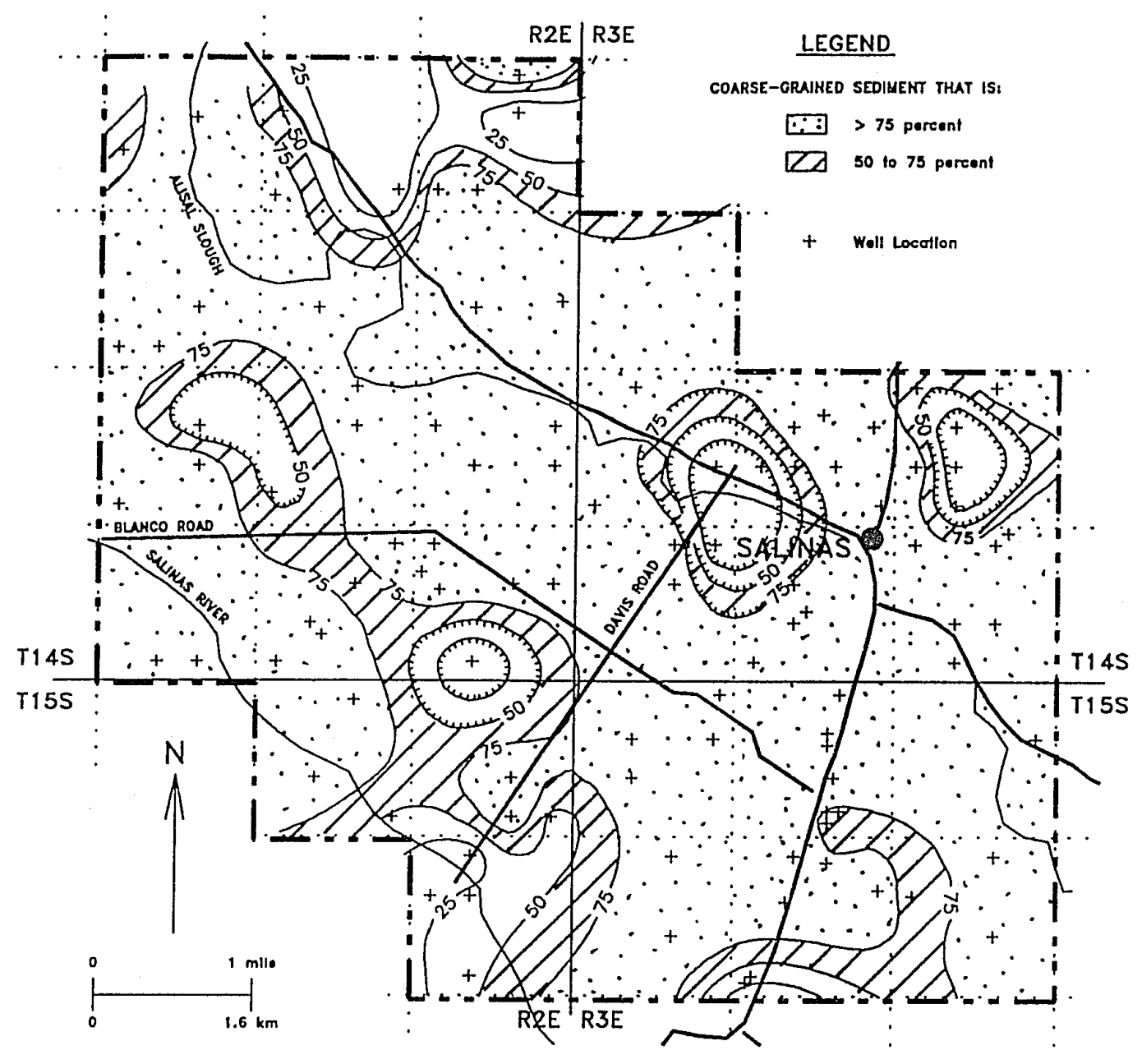

Figure 18. Texture contour map at elevation -140 feet showing the percentage of coarse-grained sediment. 


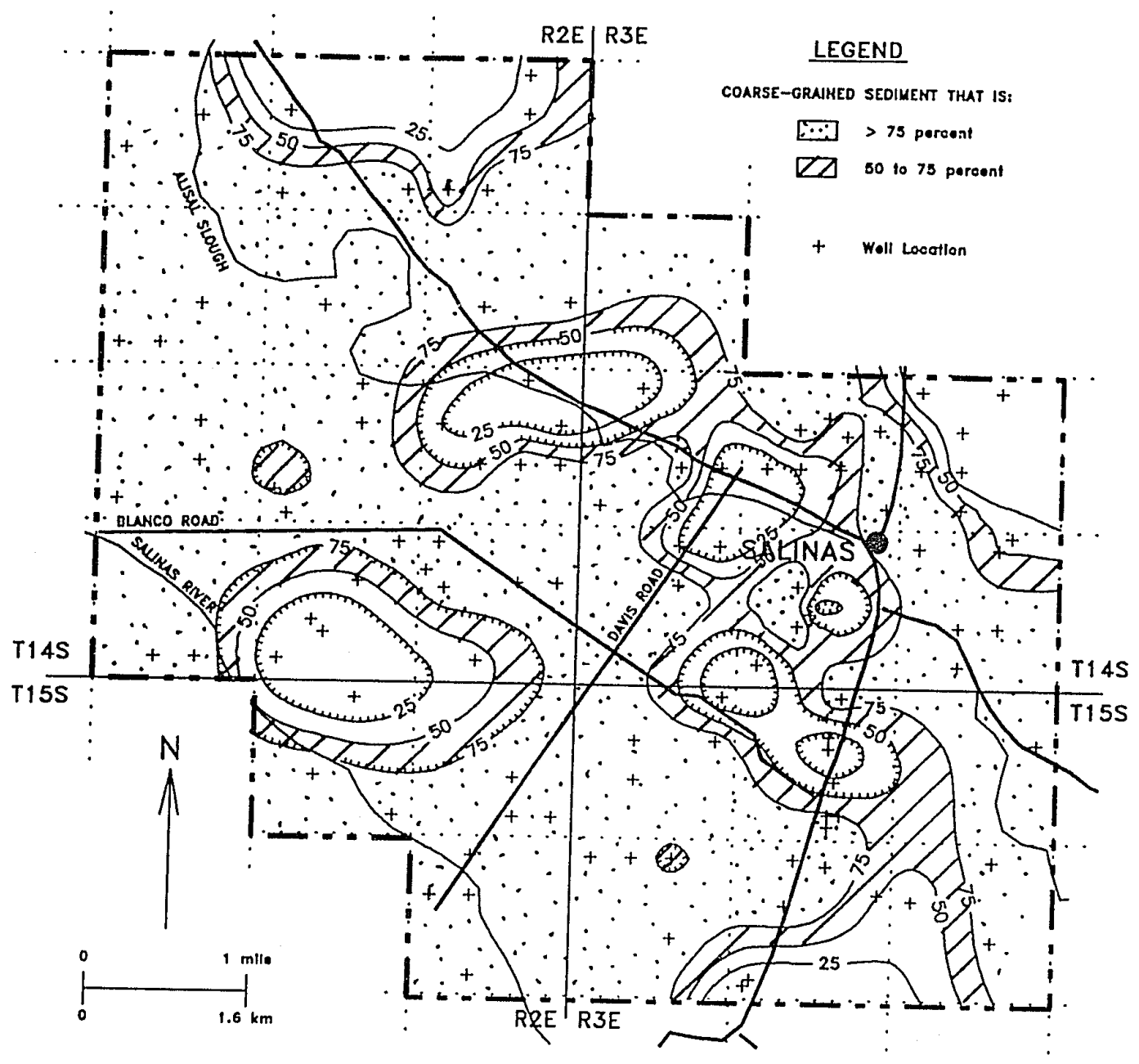

Figure 19. Texture contour map at elevation -120 feet showing the percentage of coarse-grained sediment. 


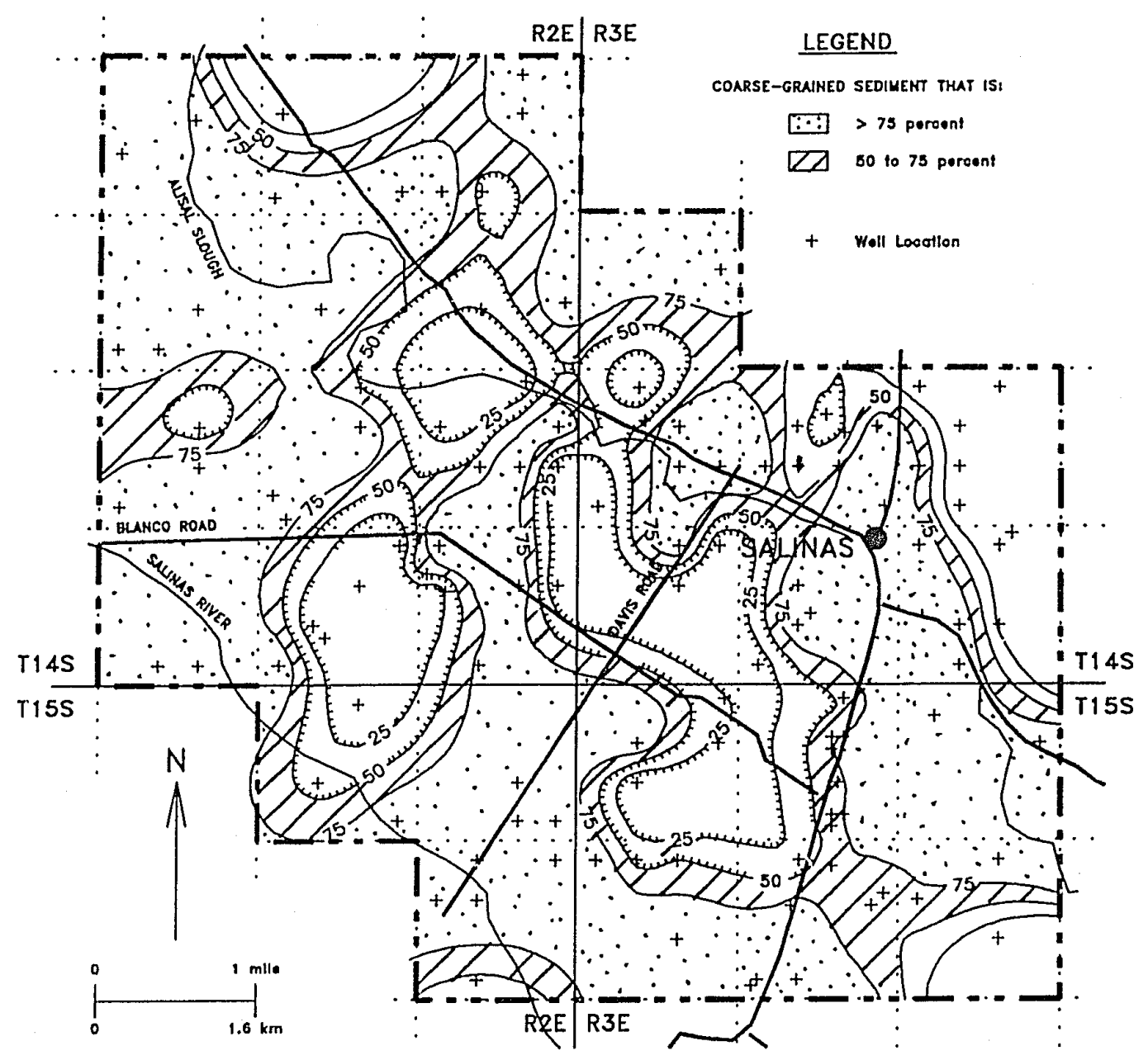

Figure 20. Texture contour map at elevation -100 feet showing the percentage of coarse-grained sediment. 


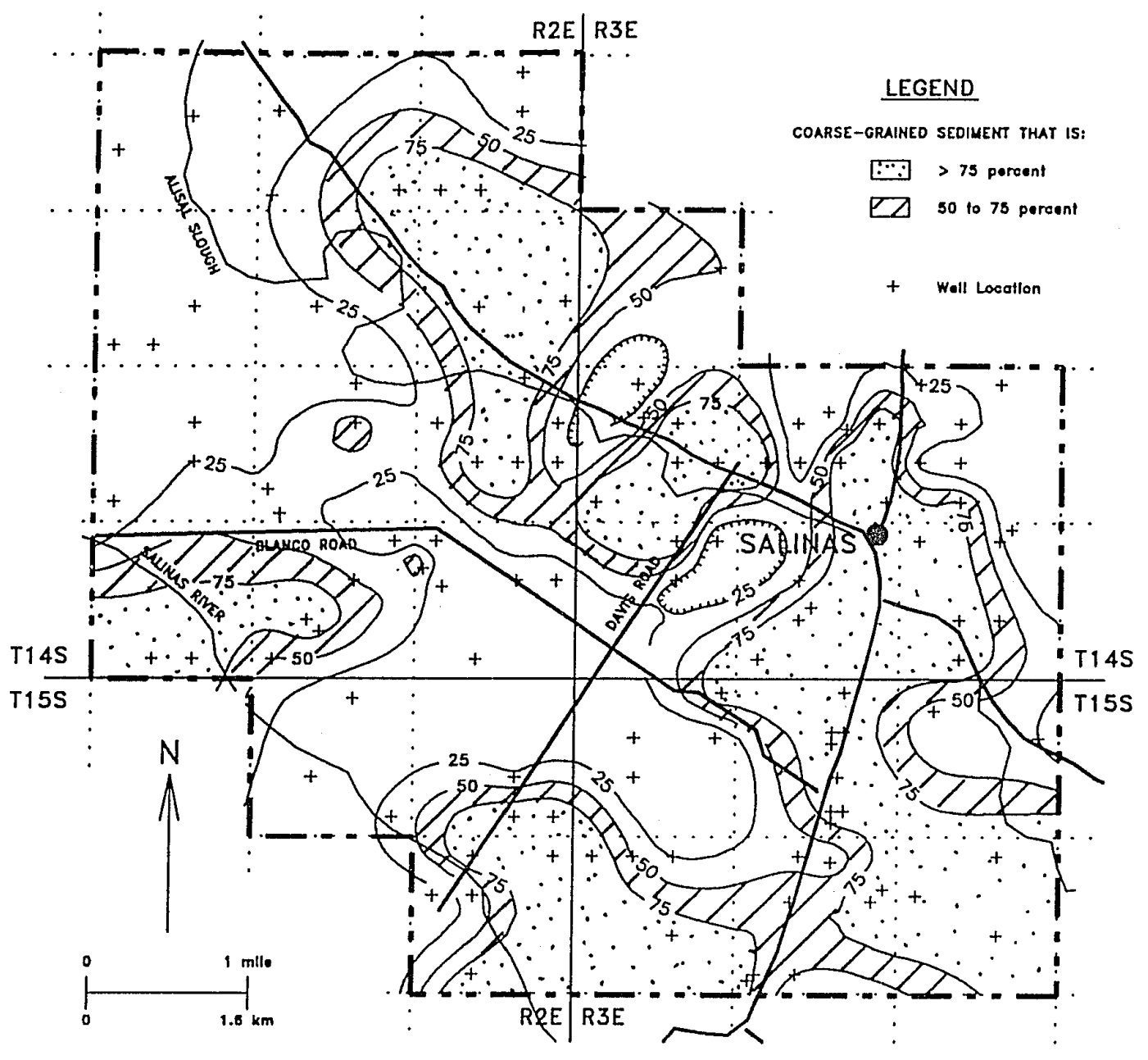

Figure 21. Texture contour map at elevation -80 feet showing the percentage of coarse-grained sediment. 


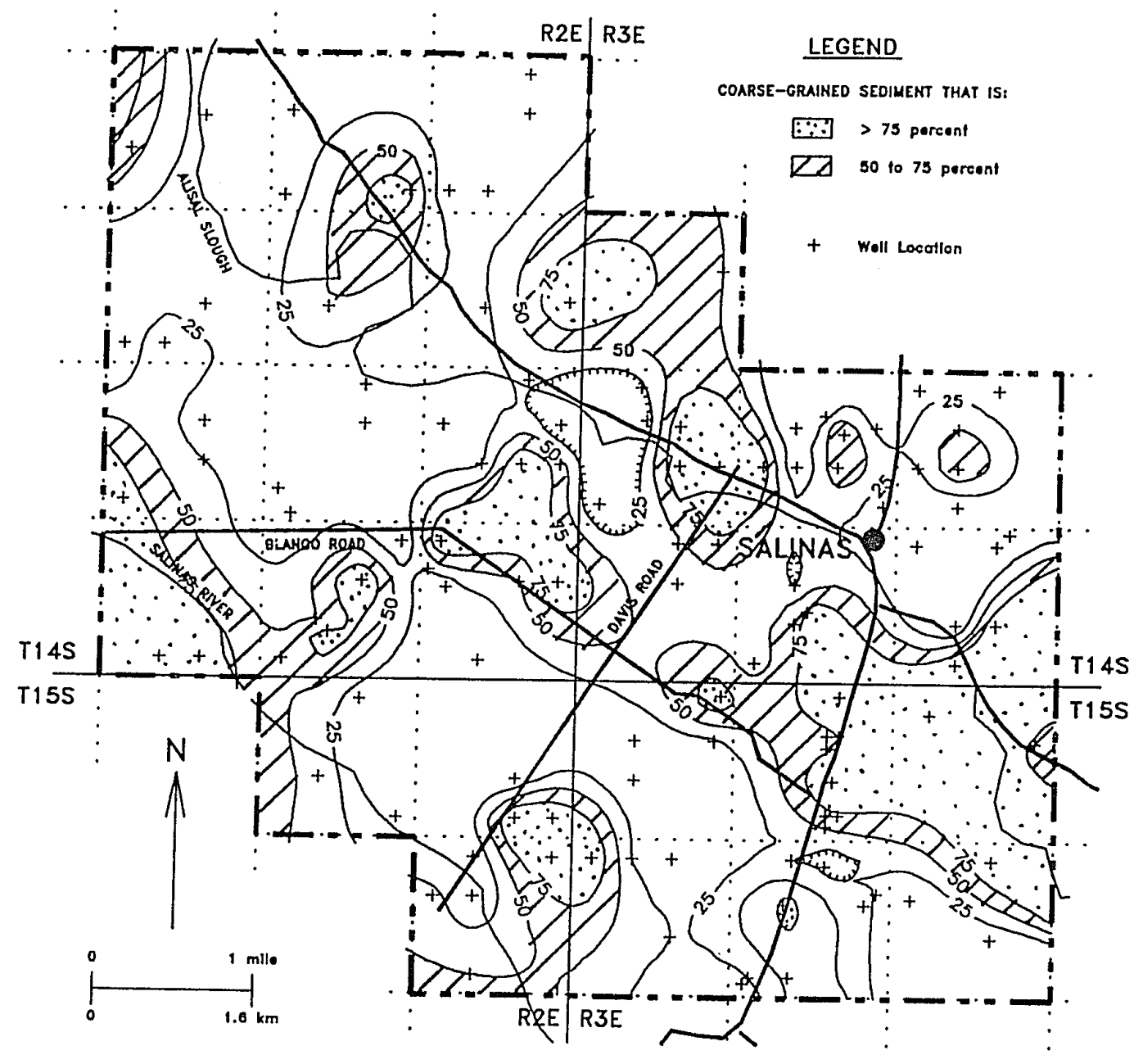

Figure 22. Texture contour map at elevation -60 feet showing the percentage of coarse-grained sediment. 


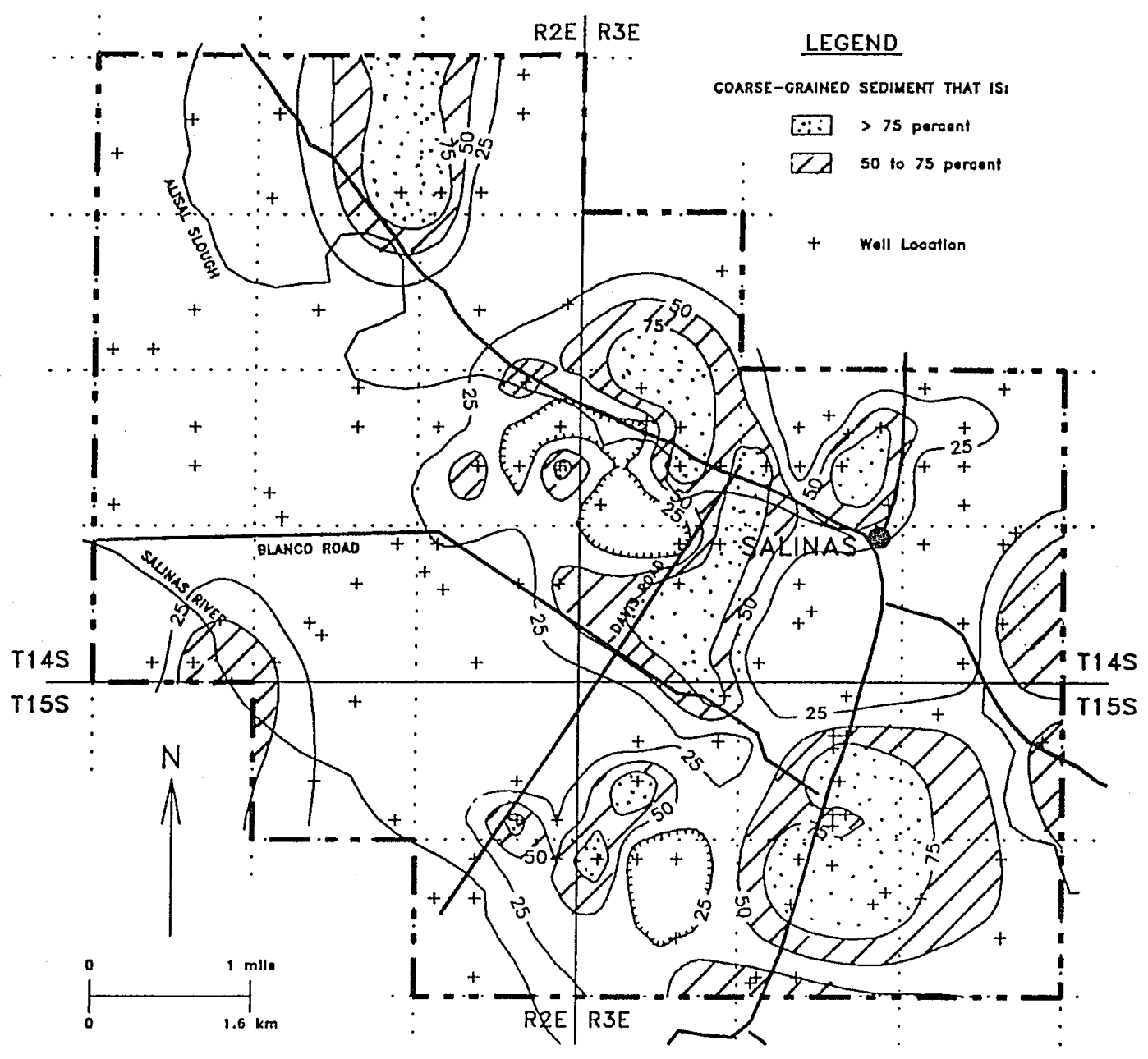

Figure 23. Texture contour map at elevation -40 feet showing the percentage of coarse-grained sediment. 


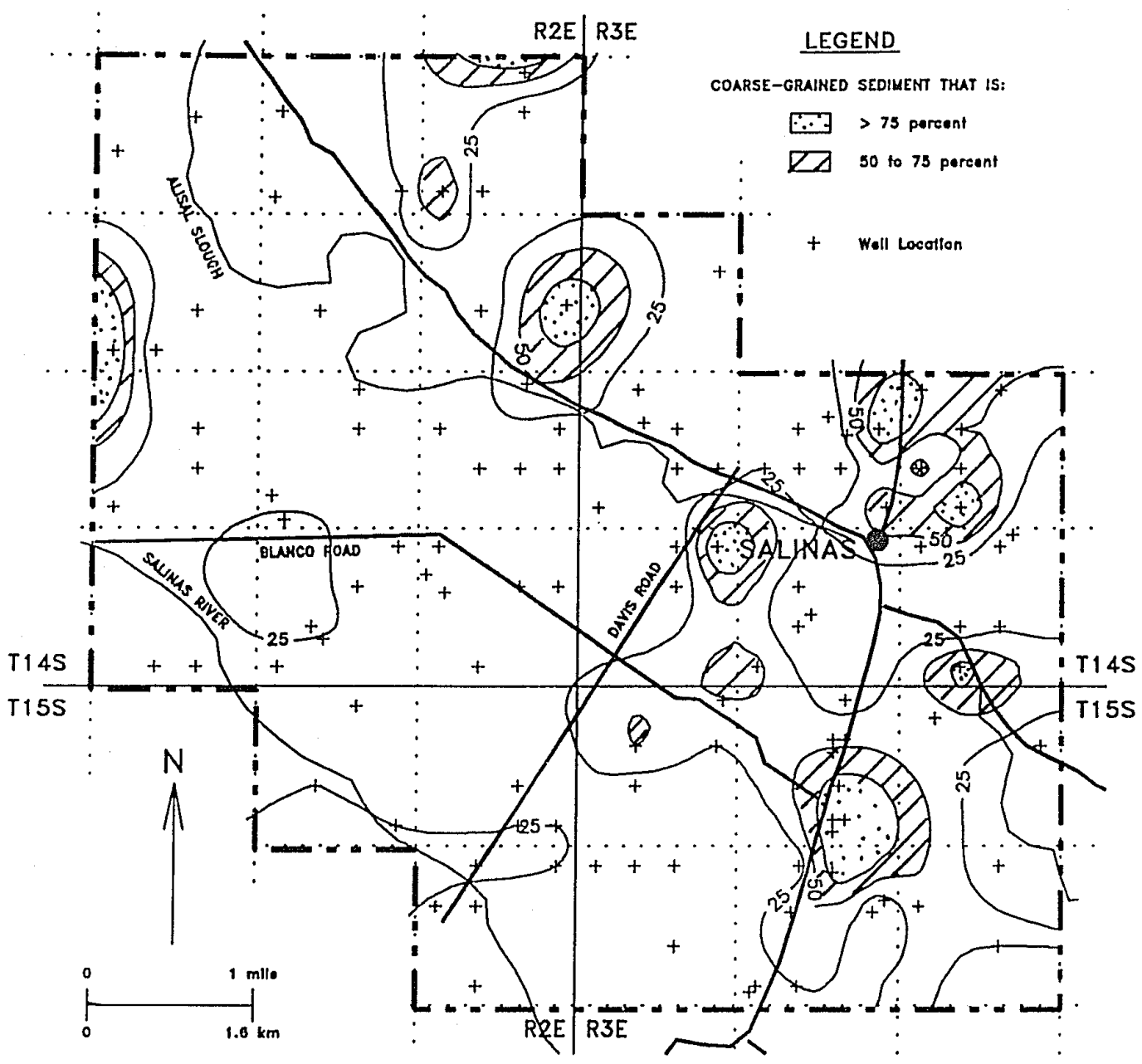

Figure 24. Texture contour map at elevation -20 feet showing the percentage of coarse-grained sediment. 


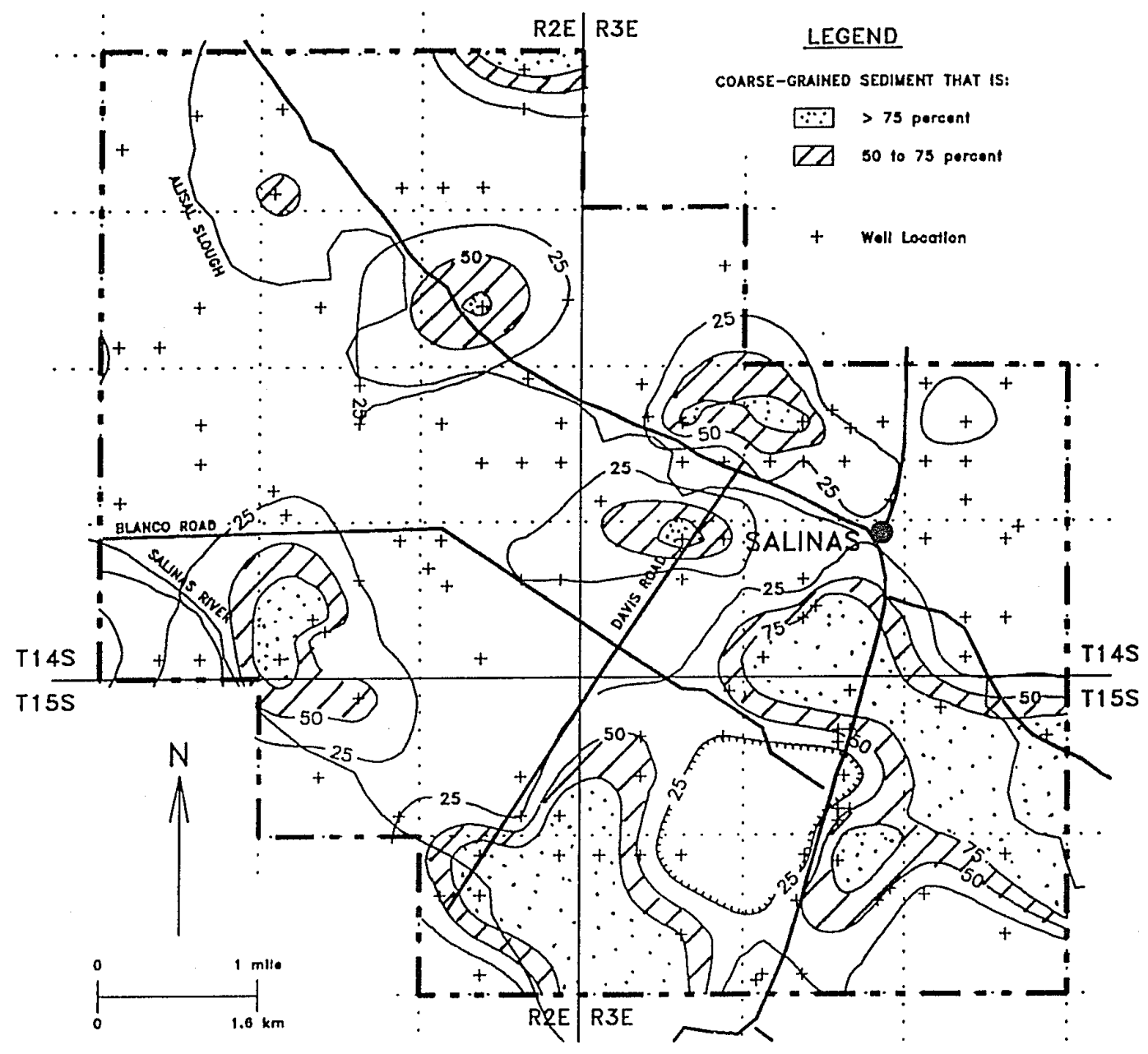

Figure 25. Texture contour map at elevation 0 feet showing the percentage of coarse-grained sediment. 
except for a south-trending lobe located in the southwest portion of the study area. Pockets of fine-grained sediment are located in the eastern half of the study area. From -280 to $-160 \mathrm{ft}$ (Figs. 11 to 17 ), coarsegrained sediment occupies about 50 percent of the study area. A 120foot-thick lens of fine-grained sediment is located in the central portion of the study area. Smaller pockets of fine-grained sediment pinch and swell predominantly along a northwest-trending alignment. From -140 to $-100 \mathrm{ft}$ (Figs. 18 to 20), coarse-grained sediment predominates with smaller pockets and lenses of fine-grained sediment located primarily along a northwest-trending alignment. From -80 to $0 \mathrm{ft}$, fine-grained sediment predominates throughout the study area with pockets of coarse-grained sediment along a northwest-trending swath in the central portion of the study area (Figs. 21 to 25).

Cross-sections $A-A^{\prime}, B-B^{\prime}, C-C^{\prime}$, and $D-D^{\prime}$ (Figs. 26 to 28) show that coarse-grained sediment is located predominantly below elevation $-100 \mathrm{ft}$. A 130-foot-thick, fine-grained deposit is centered in the study area between elevations $-150 \mathrm{ft}$ and $-310 \mathrm{ft}$. Within the coarsegrained sediment are discontinuous, 10-to 50-foot-thick, lenticular bodies of fine-grained sediment.

Above elevation $-100 \mathrm{ft}$, the sediment is predominantly finegrained with lenses of coarse-grained sediment. Cross-sections $C_{-} C^{\prime}$ and $D-D^{\prime}$ show locally continuous coarse-grained sediment from elevation -340 $\mathrm{ft}$ to $0 \mathrm{ft}$. The fence diagram in Figure 29 illustrates the discontinuous distribution of these deposits as they pinch and swell. 


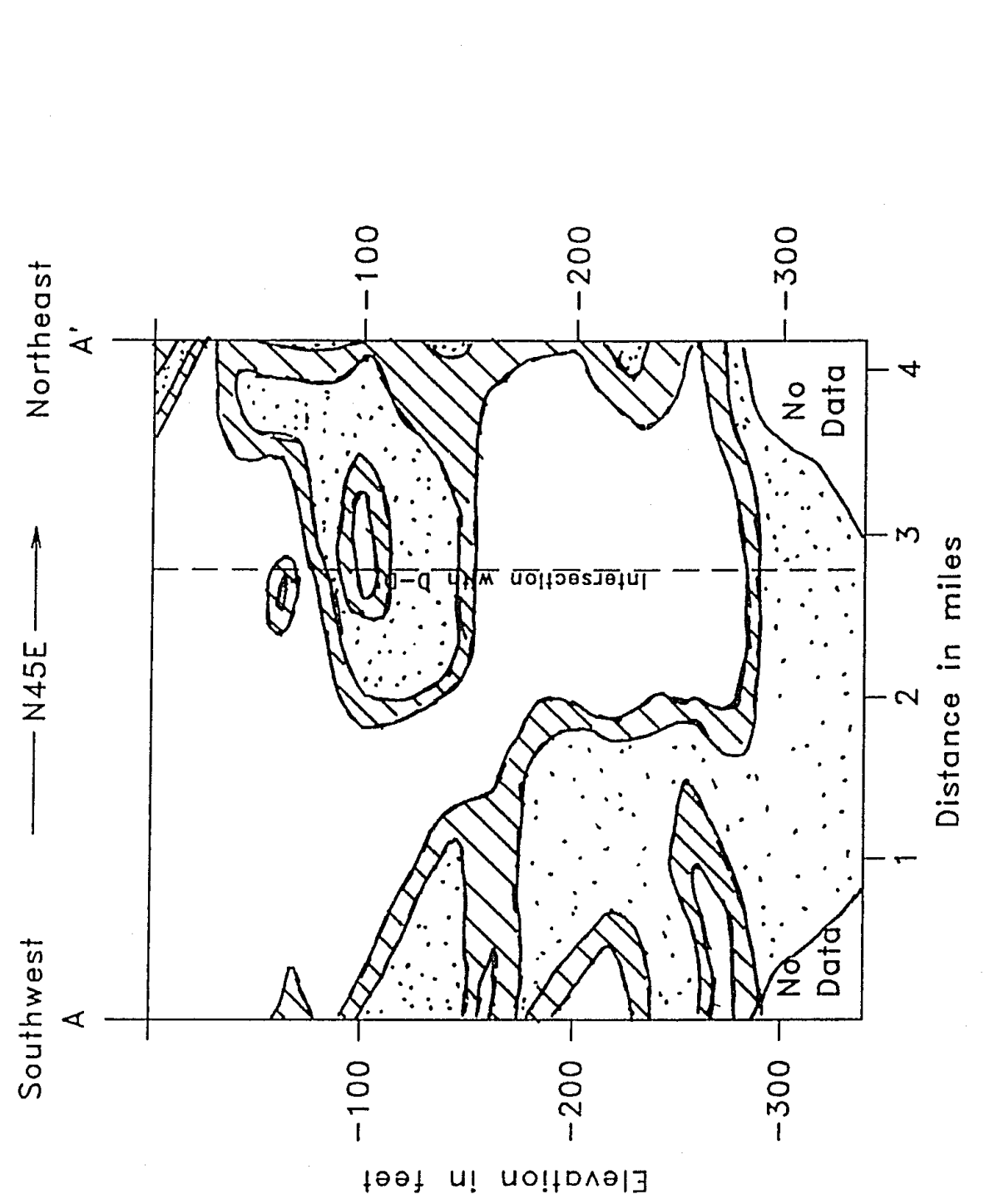

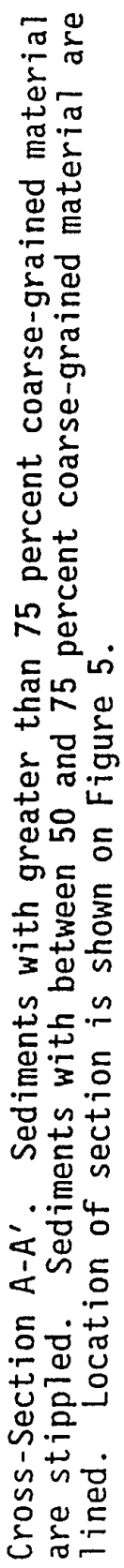

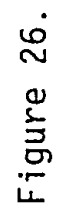




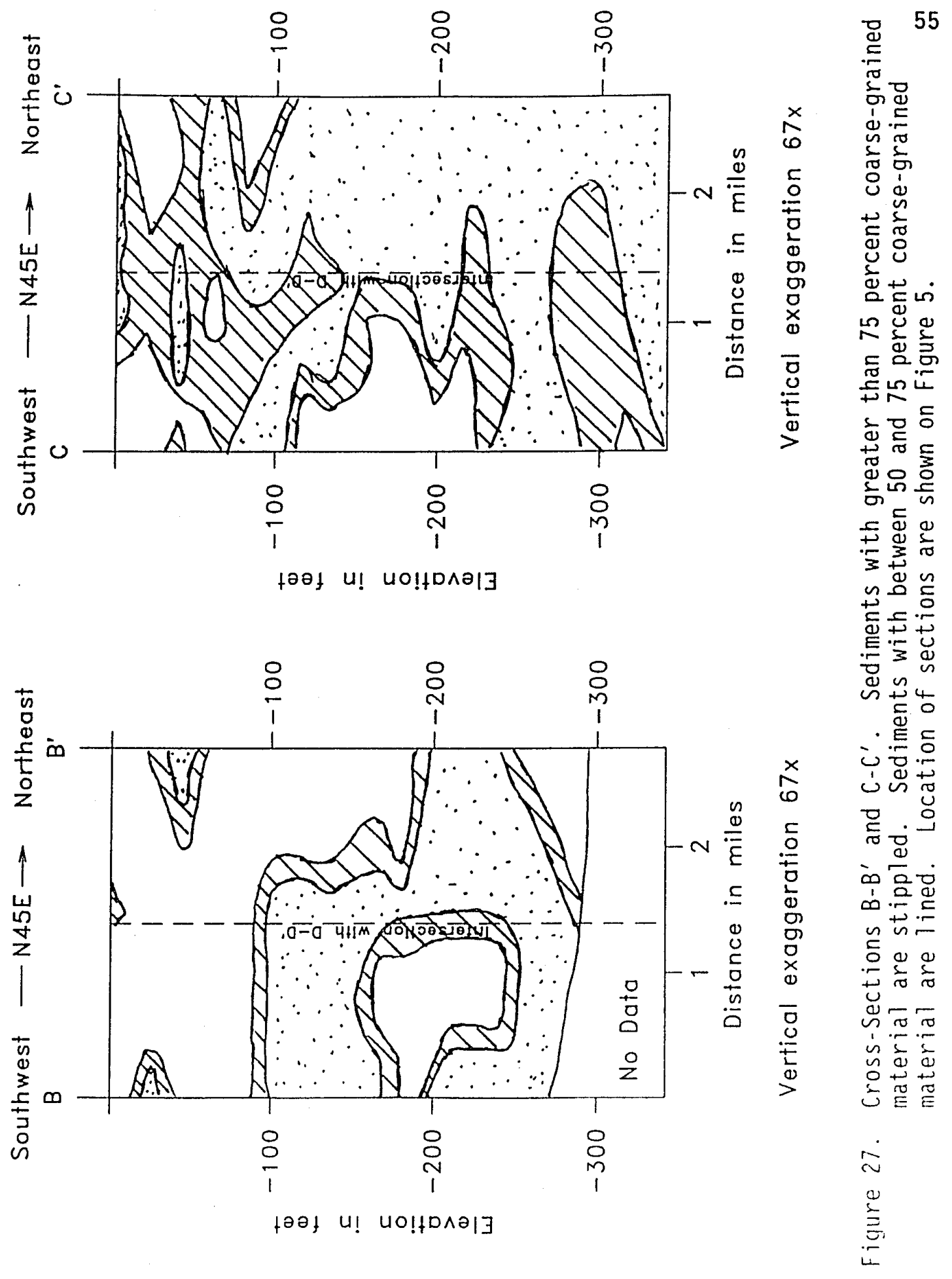




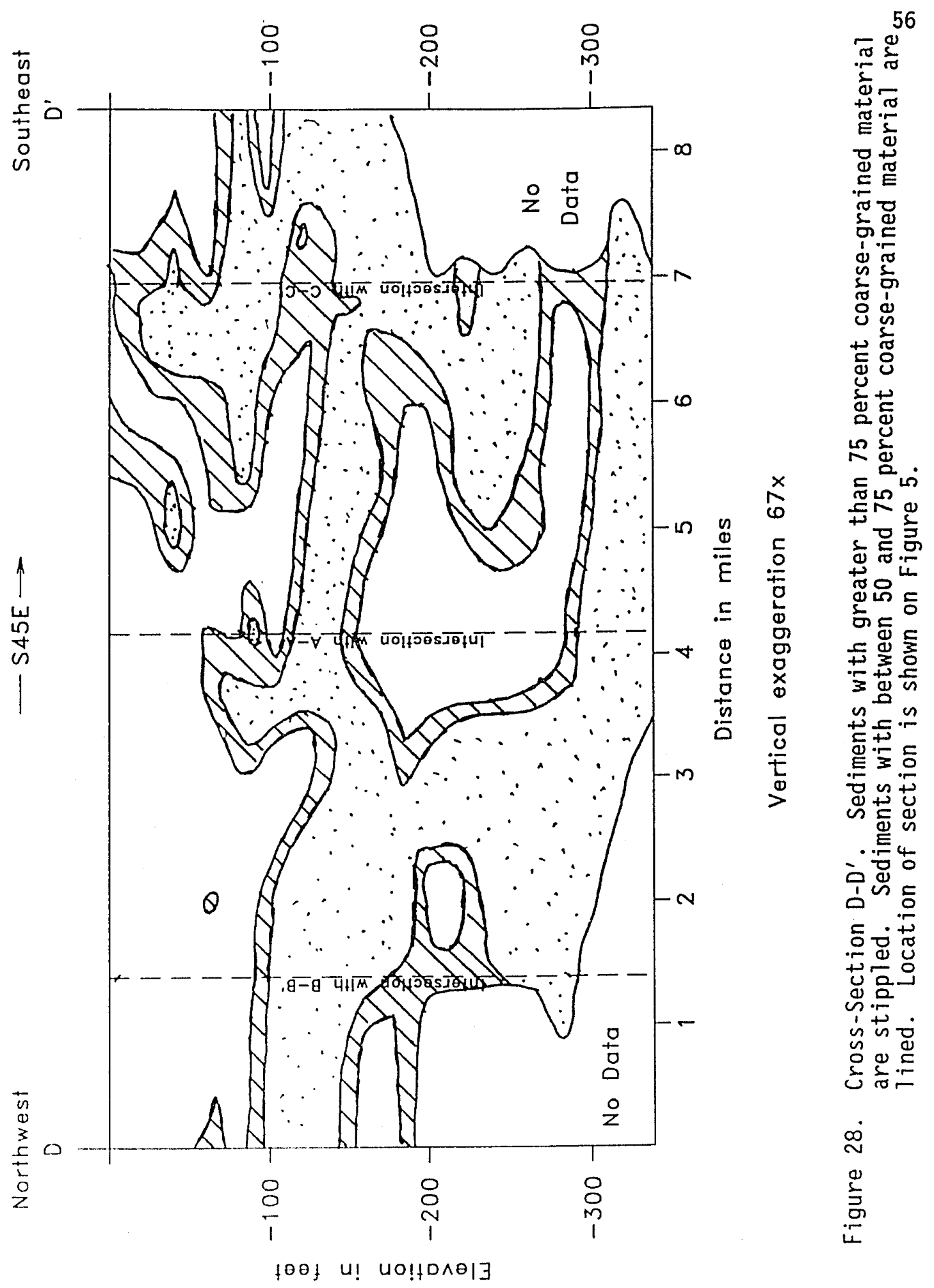




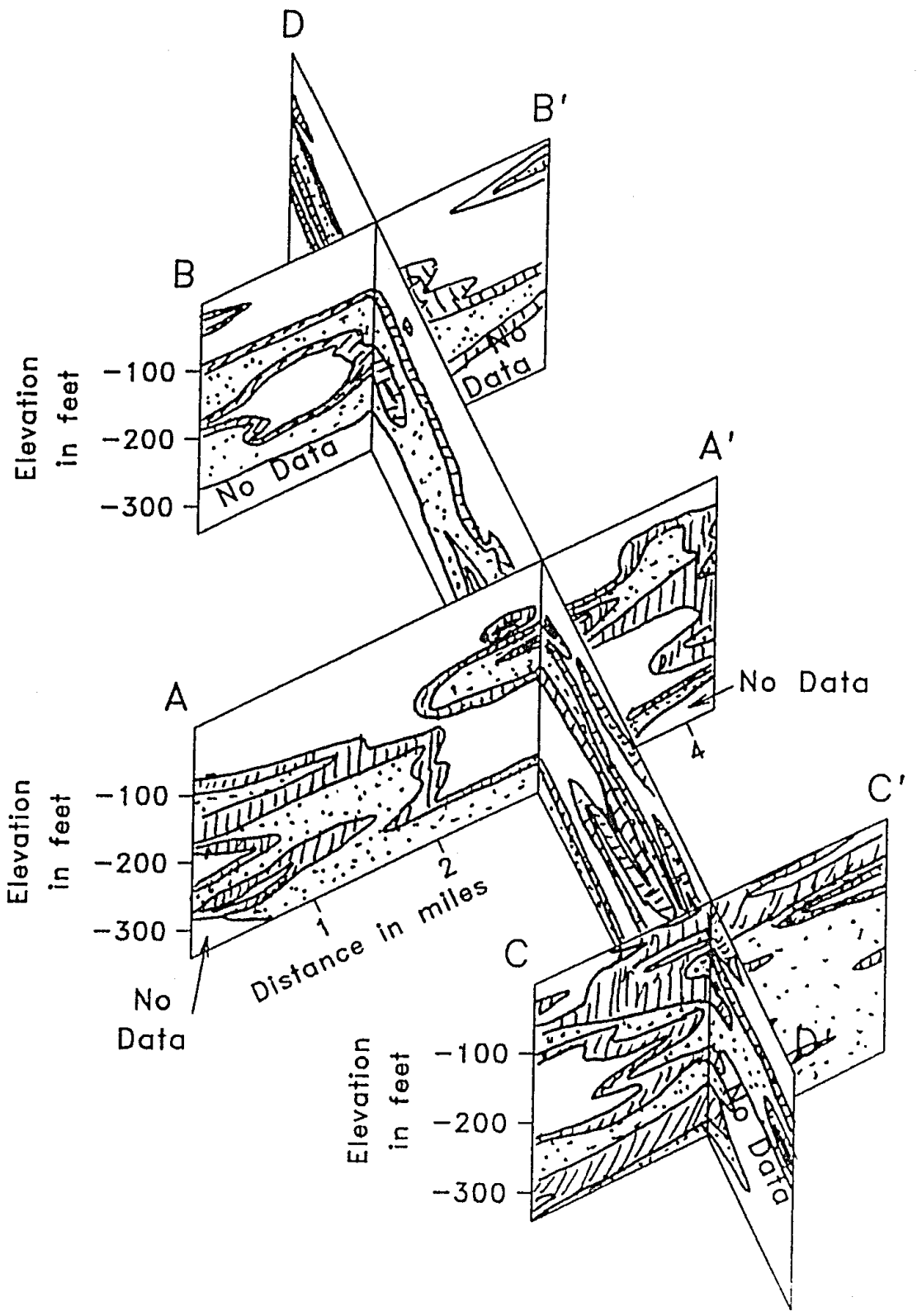

Vertical exaqueration $65 x$

Figure 29. Fence diagram of Cross-Sections $A-A^{\prime}, B-B^{\prime}, C-C^{\prime}$, and $D-D^{\prime}$. Sediments with greater than 75 percent coarse-grained material are stippled. Sediments with between 50 and 75 percent coarse-grained material are 1 ined. Locations of sections are shown on Figure 5. 
Aquifer Chemistry

Water quality analyses from 36 wells (Appendix 1, 2, 3, and 4) were used to prepare Stiff diagrams to determine the water type in the "180-foot" pressure aquifer. The water type in the 36 wells shows a change in major-ion concentration from calcium-bicarbonate water to sodium-sulphate water. From 1954 to 1959, the average water type throughout the study area was calcium-bicarbonate, with an average of 37 percent calcium and 36 percent bicarbonate. During the 1960 's, the average water type throughout the study area was calcium-sodiumchloride-sulphate-bicarbonate, with an average of 35 percent calcium and sodium, 34 percent chloride, 33 percent sulphate, and 32 percent bicarbonate. From 1970 to 1977, the average water type throughout the study area was calcium-sodium-sulphate, with an average of 35 percent calcium and sodium, and 36 percent sulphate (Appendix 3). However, in the northern portion (Appendix 4) of the study area the average water type from 1954 to 1977 was calcium-bicarbonate, with an average of 37 percent calcium, and 39 percent bicarbonate. In the central highsalinity plume area the average water type from 1954 to 1977 was sodiumcalcium-sulphate, with an average of 35 percent sodium, 34 percent calcium, and 37 percent sulphate. In the southern portion of the study area the average water type from 1954 to 1977 was calcium-bicarbonate, with an average of 38 percent calcium and 38 percent bicarbonate. Analyses were performed to evaluate the relative contribuition of agricultural return water and sea water intrusion to the changes in the ground water chemistry. The agricultural return water collected from 
the Blanco Drain in 1965 (CDWR, 1969) can be classified as a sodiumsulphate water type. Sea water (Snow and others, 1990) is classified as sodium-chloride water. The Stiff diagrams for Blanco Drain and for sea water are shown in Figure 30.

Three wells with a series of water quality analyses were chosen to show a representative history of the changes in the water types. The locations of the three representative wells are shown on figure 6 . The series of water quality analyses from Well 14S/2E-23J1 (Figs. 31 to 34 and Appendix 1, 2, 3, and 4) shows the predominant major cation(s)anion(s) changing from calcium-bicarbonate water in 1955, to sodiumsulphate water in 1958, to sodium-bicarbonate water in 1959, back to calcium-bicarbonate water in 1960, to sodium-sulphate-chloride water in 1961, to calcium-chloride water in 1965, to calcium-bicarbonate water in 1966, and calcium-chloride water in 1973. In this example, even though the predominant cations or anions change the water classification, the ratio of calcium to sodium and the ratio of bicarbonate to chloride is fairly close to one throughout the interval studied. Historically, between 1955 and 1972, this well would be classified as calcium-sodiumbicarbonate-chloride-sulphate water.

Wel1 14S/3E-30E1 (Figs. 35 and 36, and Appendix 1, 2, 3, and 4) shows widely varying water. The water type changed from calciumbicarbonate-chloride in 1955, to sodium-chloride in 1957, to calciumchloride in 1962, then to sodium-chloride in 1963. From 1963 to 1977, the sodium-chloride concentration remained relatively constant and bicarbonate was the second major anion. However, in 1975 and 1977 , 


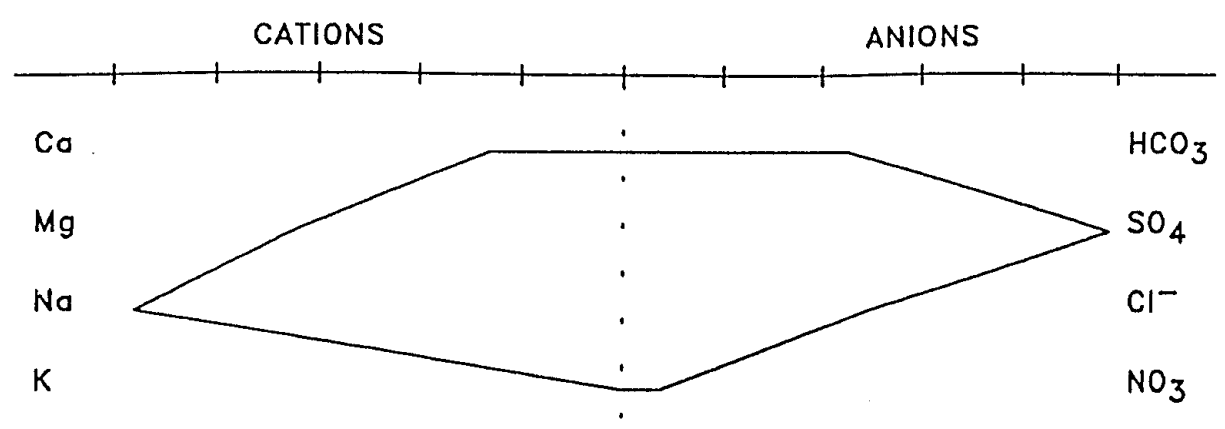

Blanco Drain Agricultural Return Water in 1965

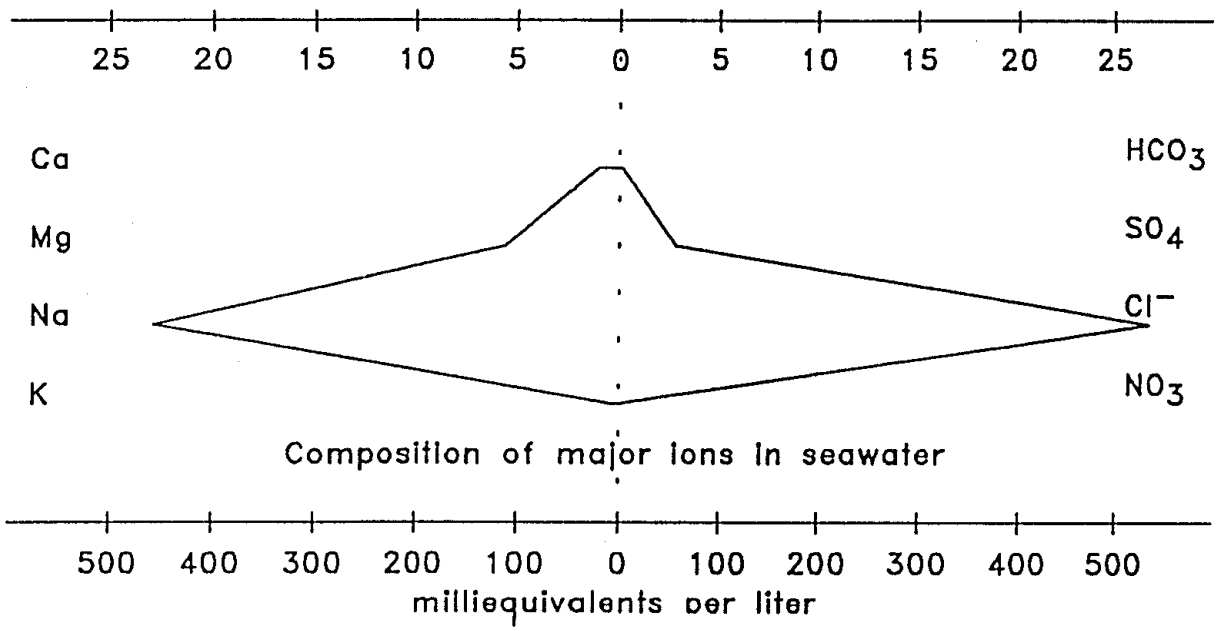

Figure 30. Representative "stiff diagrams" of Blanco Drain agricultural return water in 1965 (top) and seawater (Snow and others, 1990). 


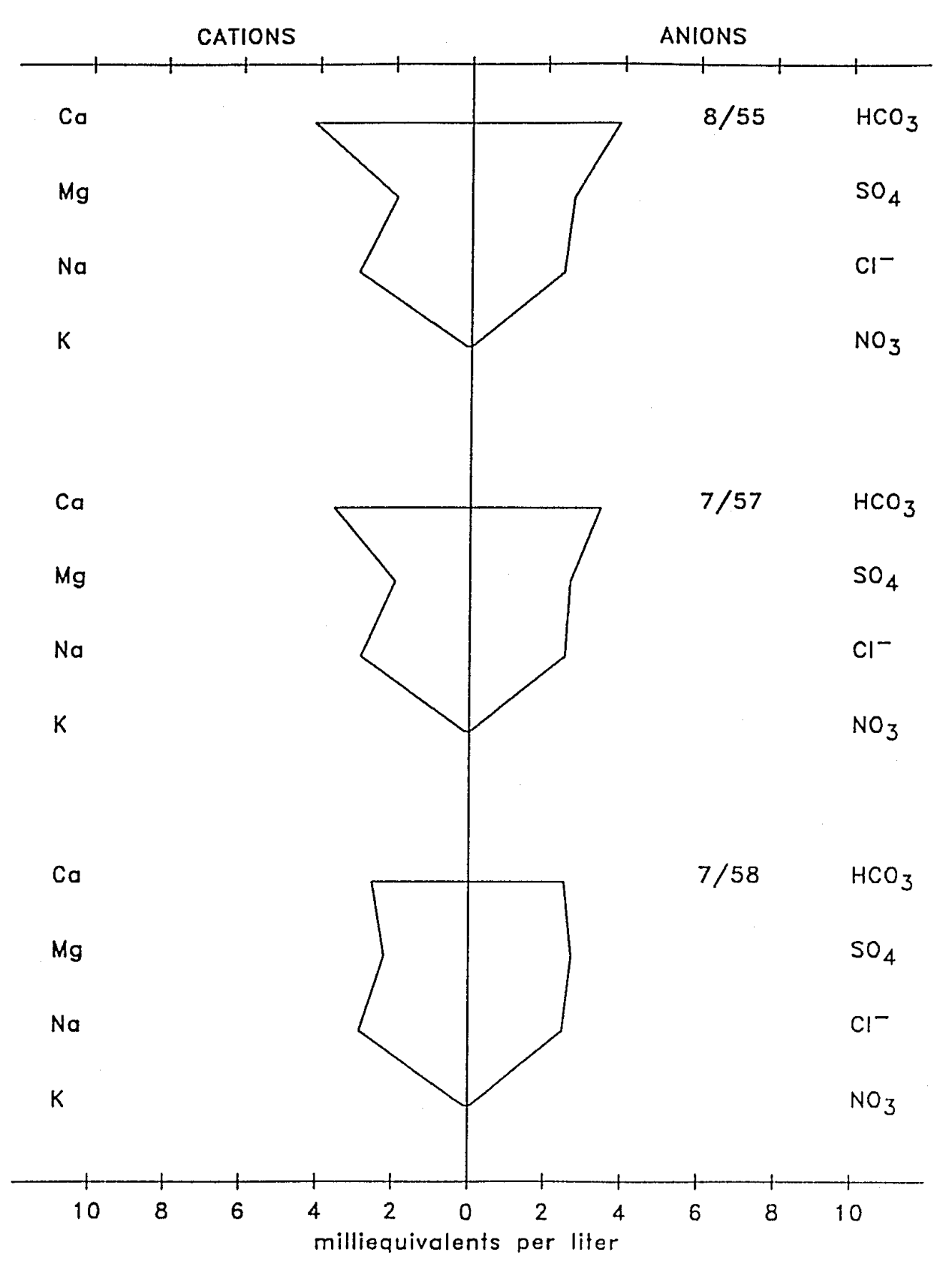

Figure 31. Stiff diagrams of water chemistry from well located at 14S/2E-23J1 sampled August 1955 (top), July 1957 (middle) and July 1958 (bottom). 


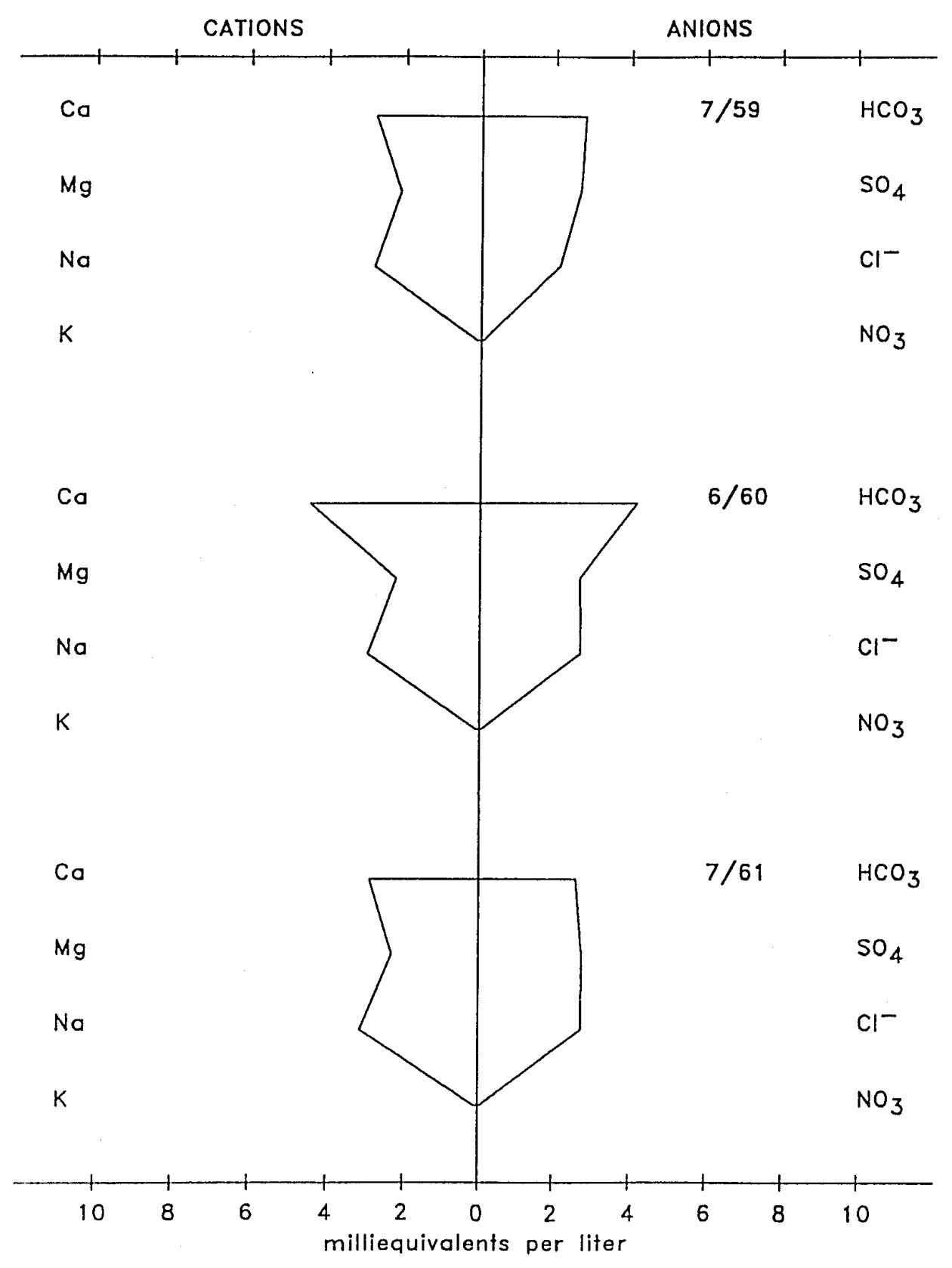

Figure 32. Stiff diagrams of water chemistry from well located at 14S/2E-23Jl sampled June 1959 (top), June 1960 (middle) and July 1961 (bottom). 


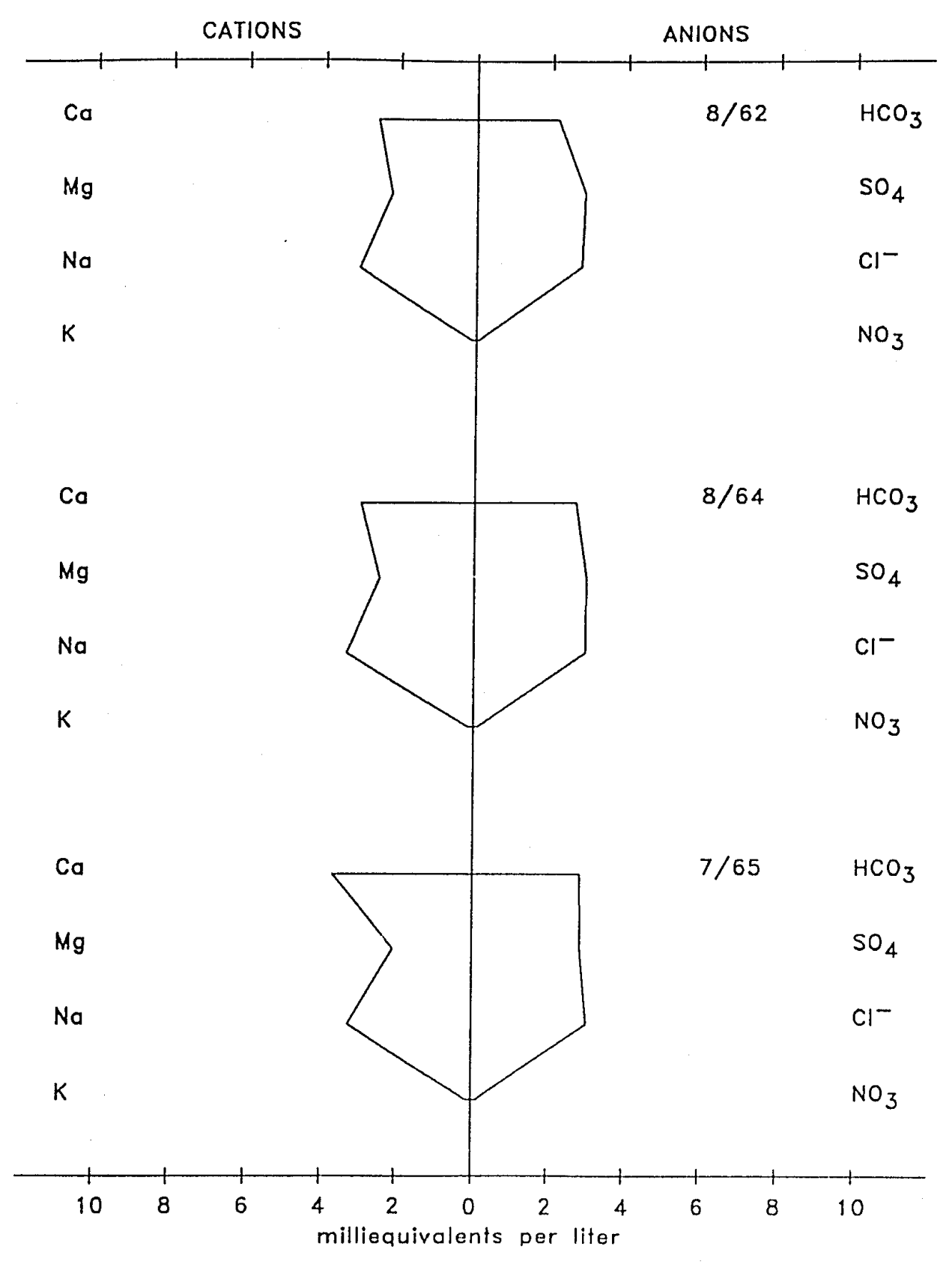

Figure 33. Stiff diagrams of water chemistry from well located at 14S/2E-23Jl sampled August 1962 (top), August 1964 (middle) and JuTy 1965 (bottom). 


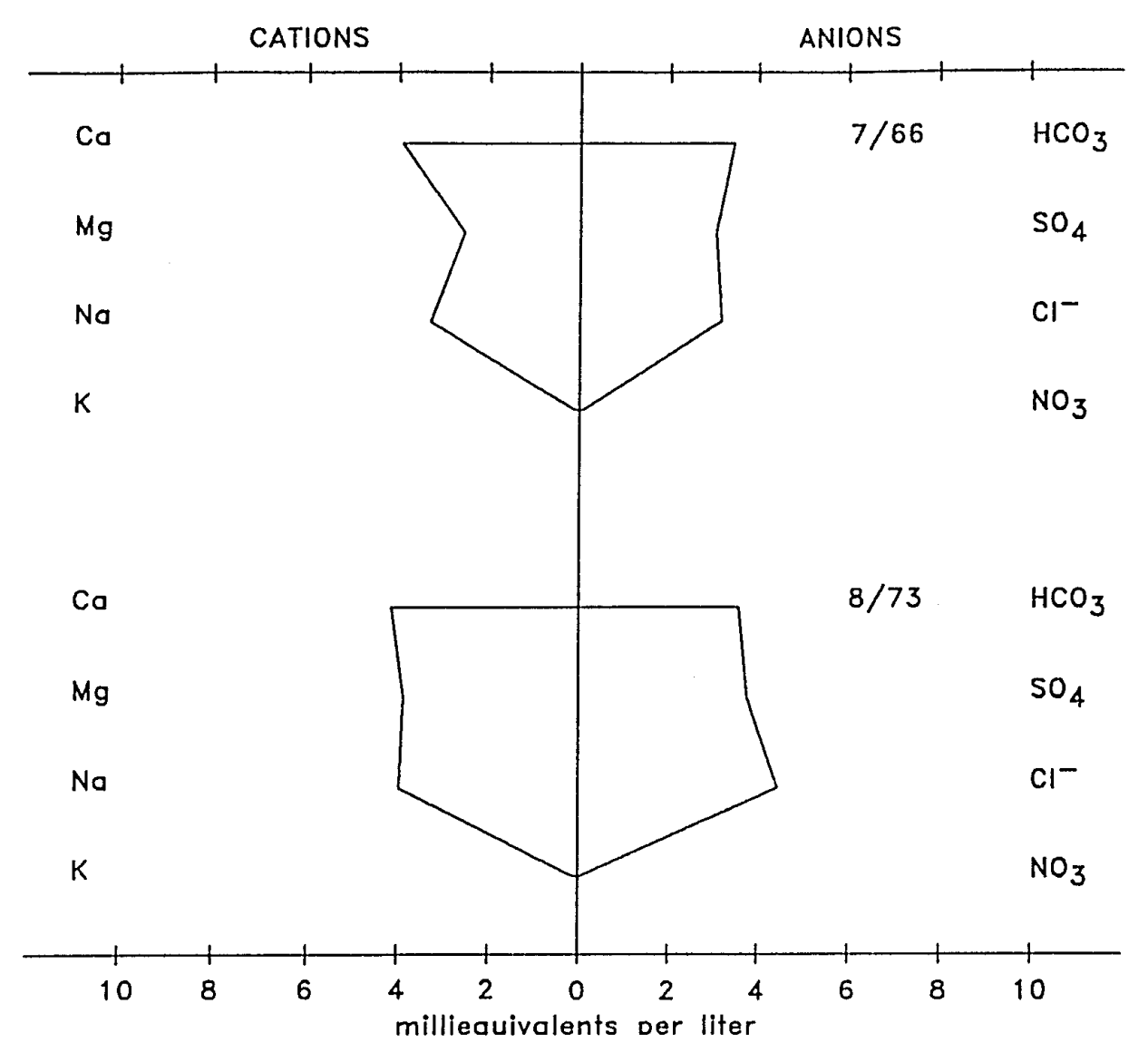

Figure 34. Stiff diagrams of water chemistry from well located at 14S/2E-23J1 sampled July 1966 (top) August 1973 (bottom). 


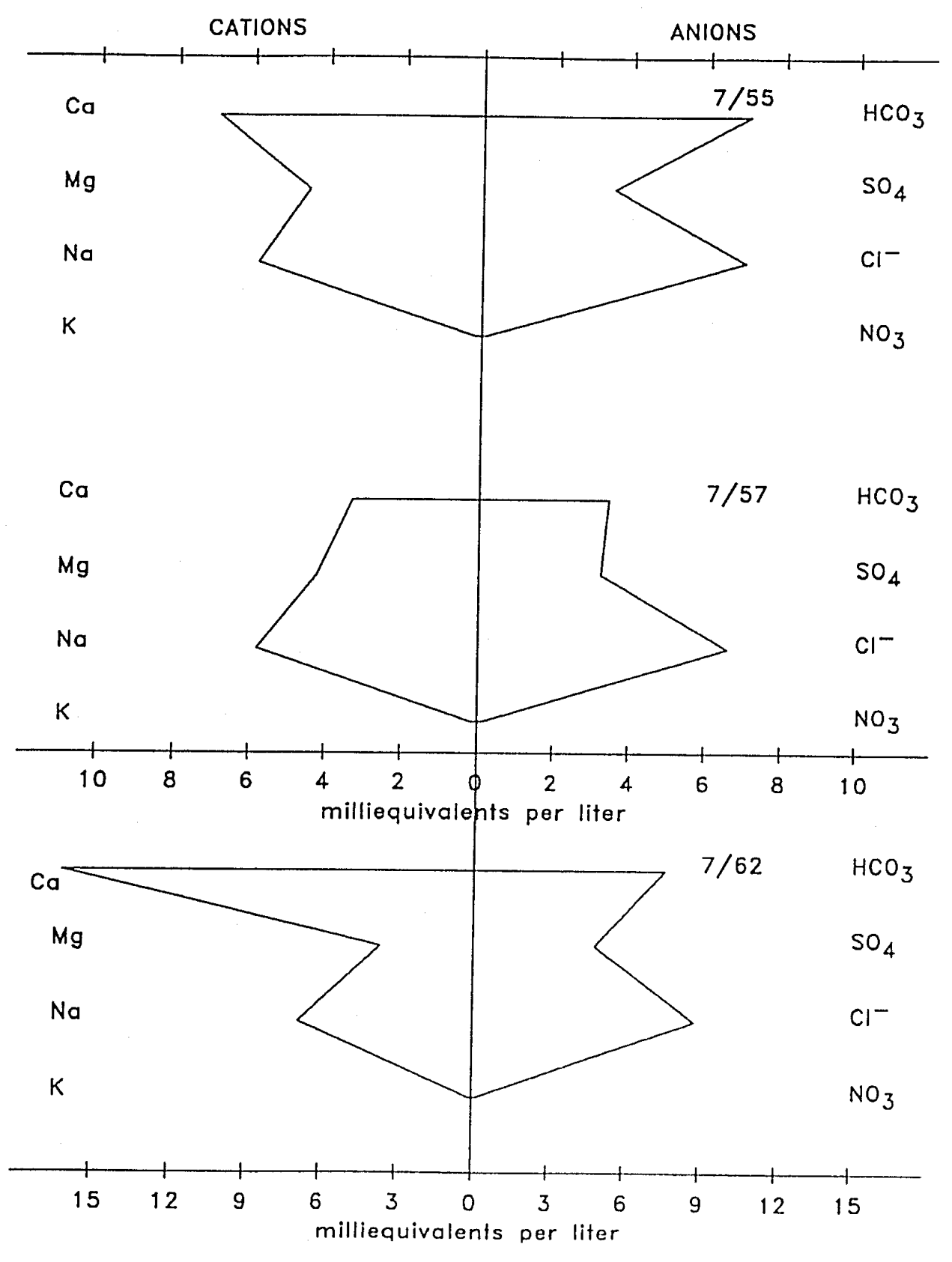

Figure 35. Stiff diagrams of water chemistry from wel1 located at $14 S / 3 E-30 E 1$ sampled July 1955 (top), JuTy 1957 (middle), and July 1962 (bottom). 


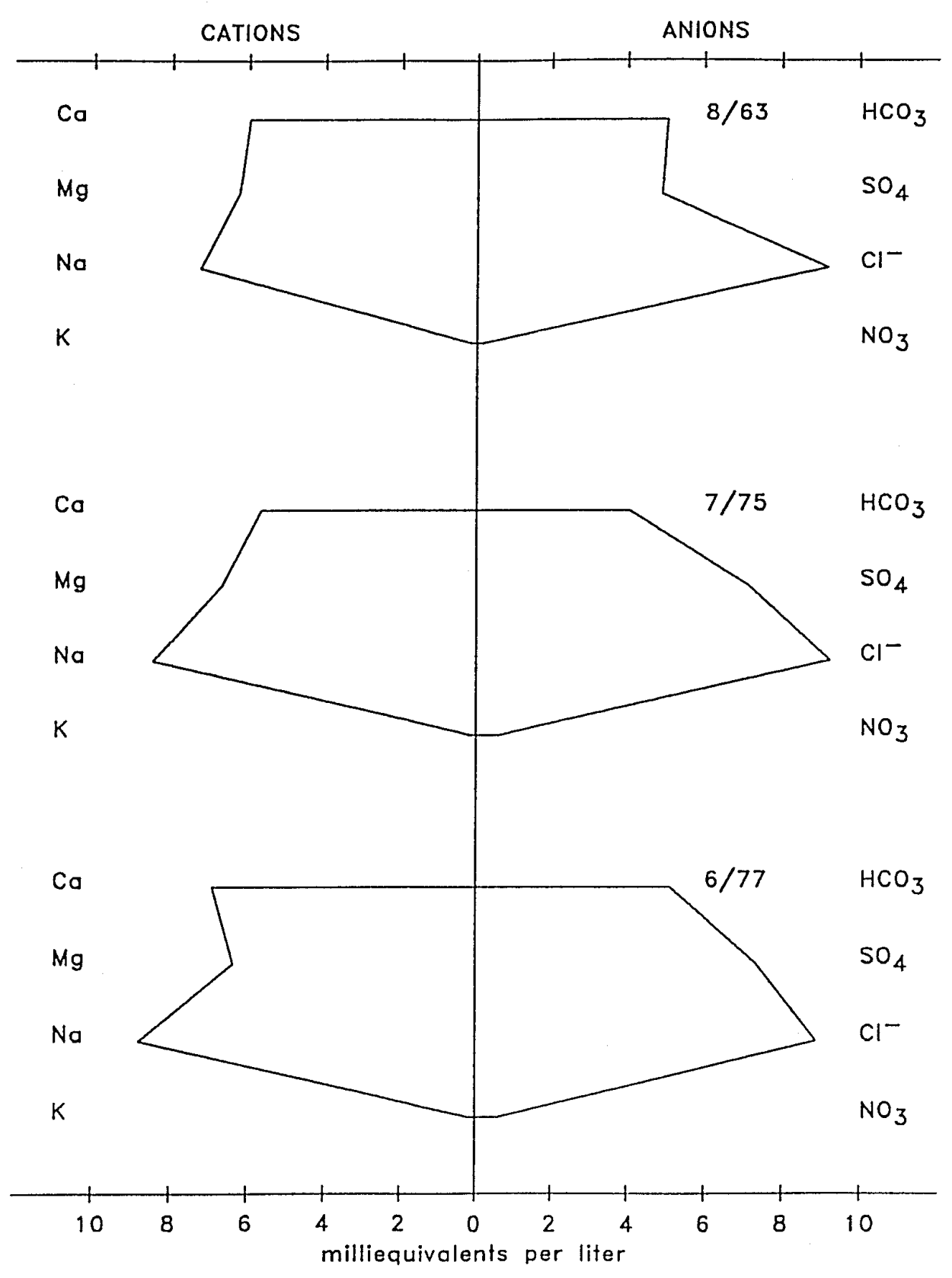

Figure 36. Stiff diagrams of water chemistry from we 11 located at 14S/3E-30E1 sampled August 1963 (top), July 1975 (middle), and June 1977 (bottom). 
sulphate was the second major anion. We11 15S/3E-04LI shows a general progression from calcium-bicarbonate water to sodium-sulphate water between 1955 and 1959 (Figs. 37 and 38, and Appendix 1, 2, 3, and 4). The recently analyzed ground waters are somewhat similar to Blanco Drain agricultural return water and not at all similar to sea water (Fig. 30). The water chemistry shows a progressive change from calciumbicarbonate water to water with higher proportions of sodium, sulphate and chloride (Appendix 3). Appendix 2 shows that, in some wells, such as Well 14S/3E-30E1, this change is due to an increase in the concentrations of sodium, magnesium, sulphate, and chloride with a less extreme decrease in calcium and bicarbonate. Appendix 4 shows that, on average, those changes are greatest in the central high-salinity plume area. Compared to the northern and southern portions of the study area, the central high-salinity plume area has lower proportions of calcium and bicarbonate, and higher proportions of sodium, magnesium, sulphate, and chloride.

Water zonation maps were prepared using the major anion and cation chemistry data from 36 wells. Not all wells were analyzed annually, so maps were made for the years that had the greatest number of water quality analyses. The selected years were 1955, 1960, 1962, 1972-73, and 1977. From the wells that were analyzed in 1955, the predominant water type was calcium-bicarbonate with a small pocket of calciumsodium-sulphate water located in the south-central area (Fig. 39). In wells analyzed in 1960, calcium-bicarbonate water was located in 3 widely separated wells in the study area (Fig. 40). One well in the 


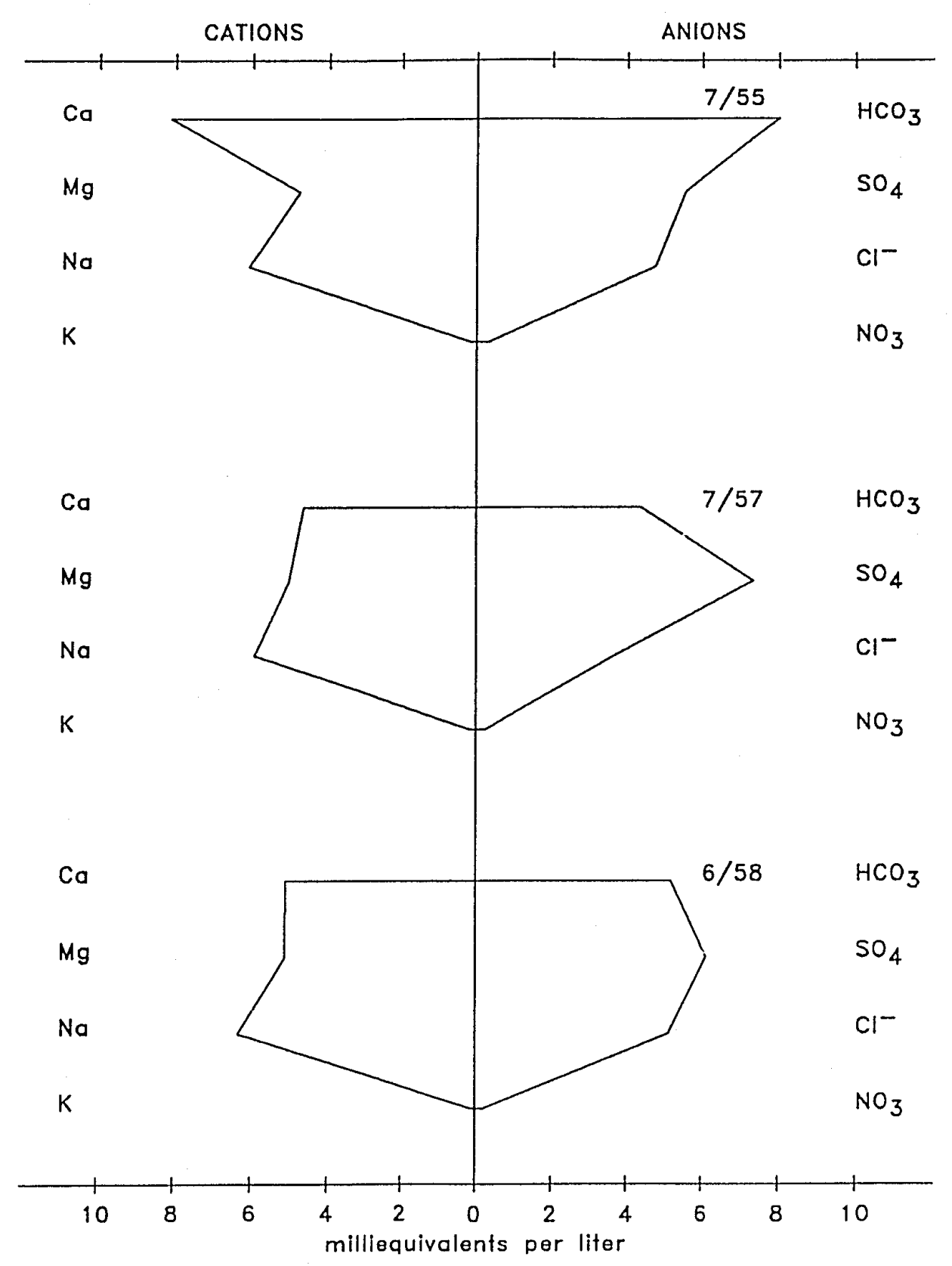

Figure 37. Stiff diagrams of water chemistry from we 17 located at 15S/3E-04Ll sampled JuTy 1955 (top), July 1957 (middle), and June 1958 (bottom). 


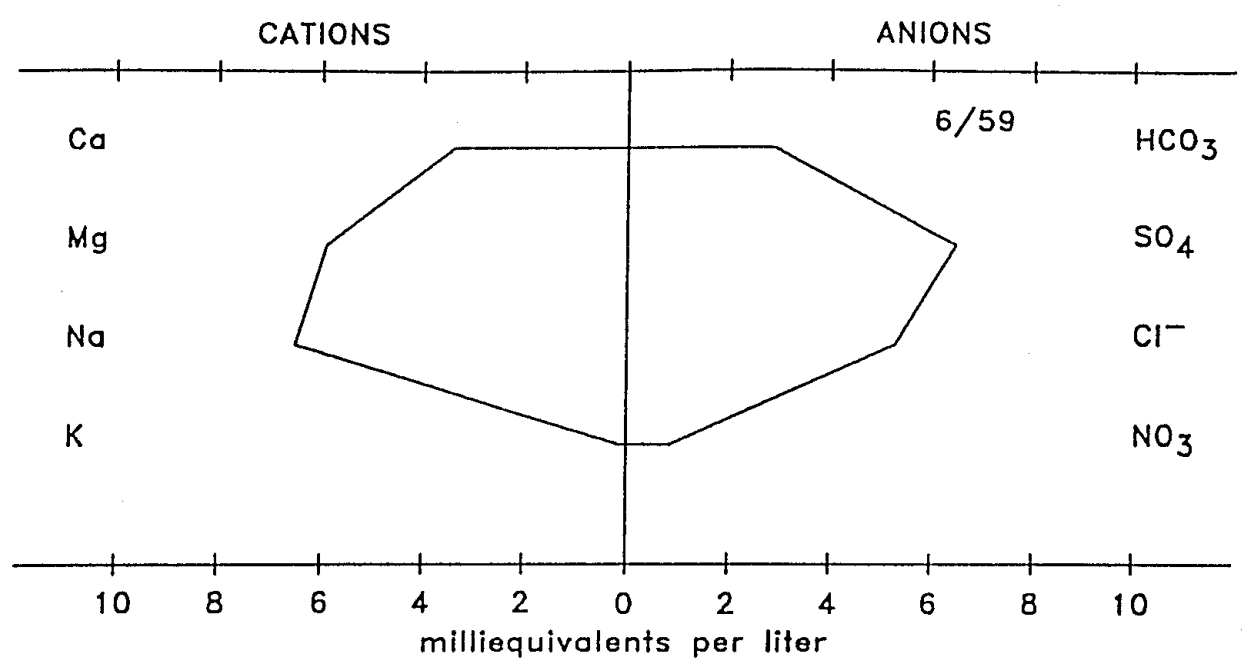

69

Figure 38. Stiff diagram of water chemistry from well located at 15S/3E-04L1 sampled June 1959. 


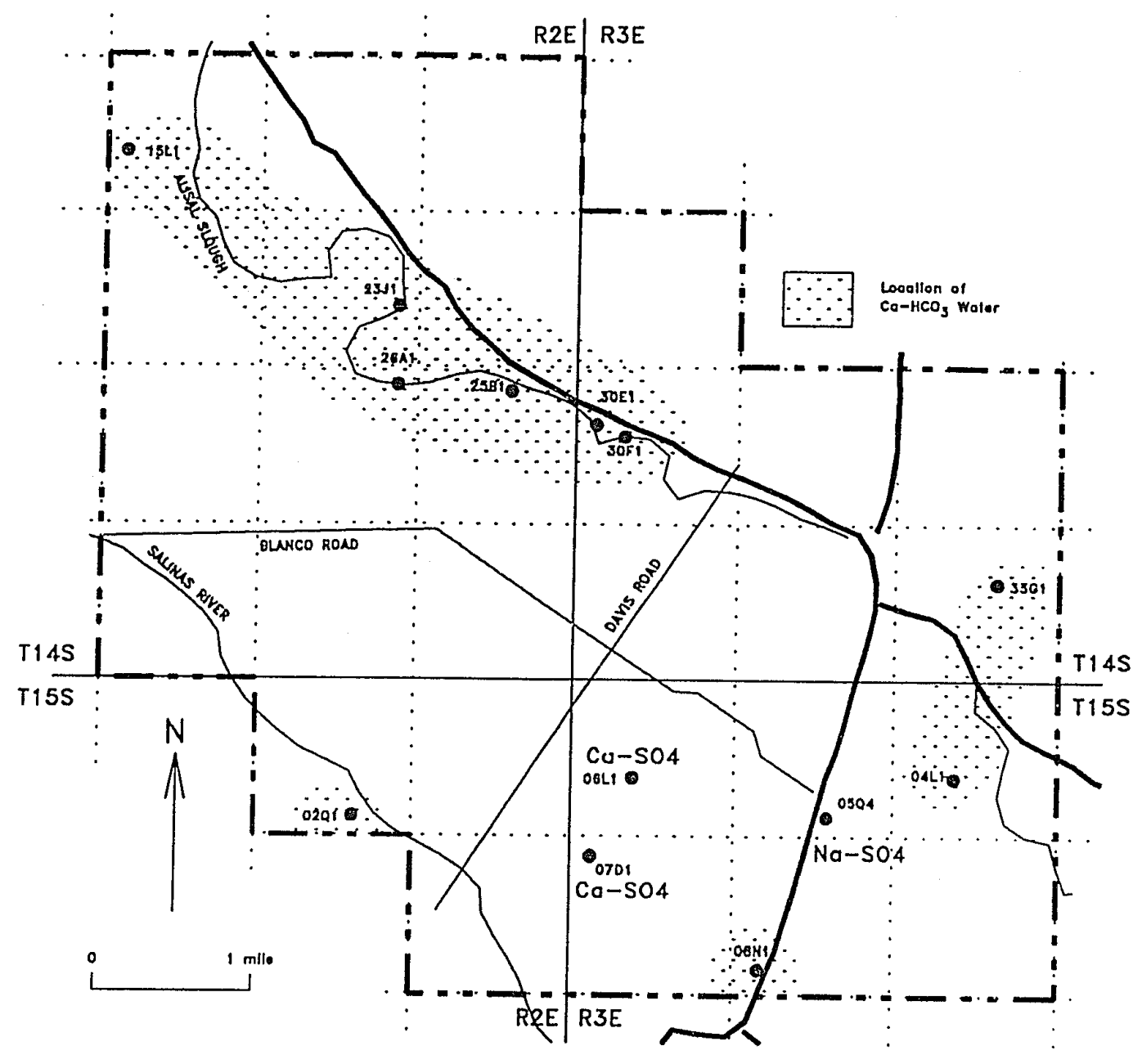

Figure 39. Water zonation map for 1955 showing the location of calciumbicarbonate ground water type. Wells where calciumbicarbonate water is not the predominant water type are labelled with the predominant cation-anion pair. Filled circles show where the water quality samples were collected. 


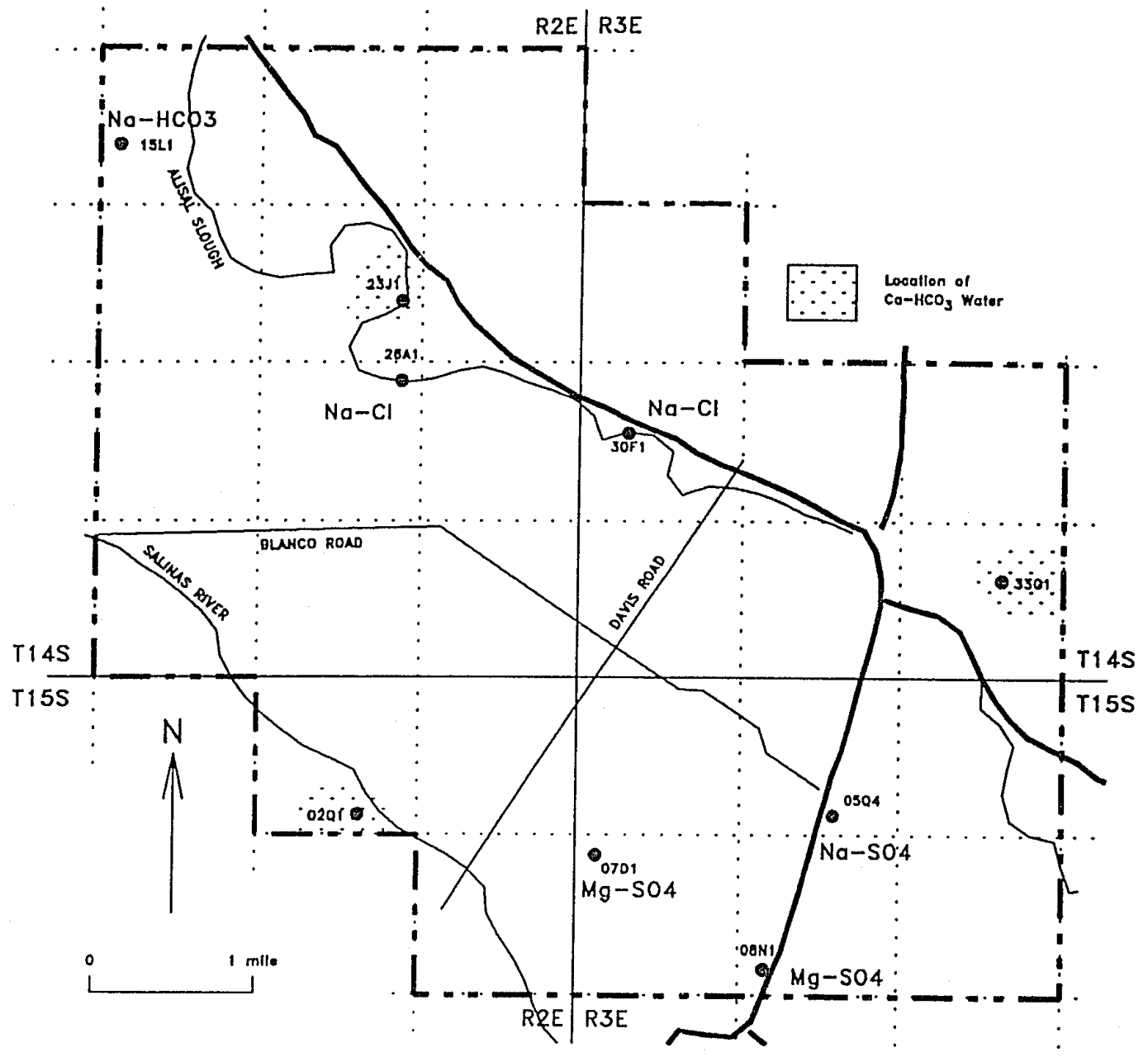

Figure 40. Water zonation map for 1960 showing the location of calciumbicarbonate ground water type. Wells where calciumbicarbonate water is not the predominant water type are labelled with the predominant cation-anion pair. Filled circles show where the water quality samples were collected. 
northwest had sodium-bicarbonate water. In the south-central area, the calcium-sodium-sulphate water had altered to magnesium-sodium-sulphate water. Sodium-chloride water appeared in the central area. In wells analyzed in 1962, calcium-bicarbonate water was located in the same regions of the study area as in 1960 (Fig. 41). Sodium-bicarbonate water was present in the northwest corner. Magnesium-sodium-sulphate water remained in the south-central area, and the sodium-chloride water in the central area had altered to calcium-sodium-chloride water. Water in one well in the north-central portion of the study area had altered from calcium-bicarbonate to sodium-sulphate water. In wells analyzed in 1972-73, the water quality analyses show calcium-sodium-bicarbonate water located around the periphery of the area (Fig. 42). Sodiumcalcium-chloride water located in the central portion of the area had expanded northward since 1962. A lobe of calcium-sulphate water appeared in the southwest portion of the area. In wells analyzed in 1977, sodium-sulphate water predominated throughout the area with the pocket of sodium-chloride water located in the central portion of the area (Fig. 43). Magnesium-chloride water appeared in one well in the northwest portion of the study area.

Eighteen diagrams were prepared to show the changes in the variation of major anions with time and major cations with time for water from 9 wells that had a minimum of 5 years each of water quality analyses (Figs. 44 to 52). Linear regressions were performed to obtain an overall trend in the change of each cation or anion with time. The major anion plots show an inverse relationship between the percent of 


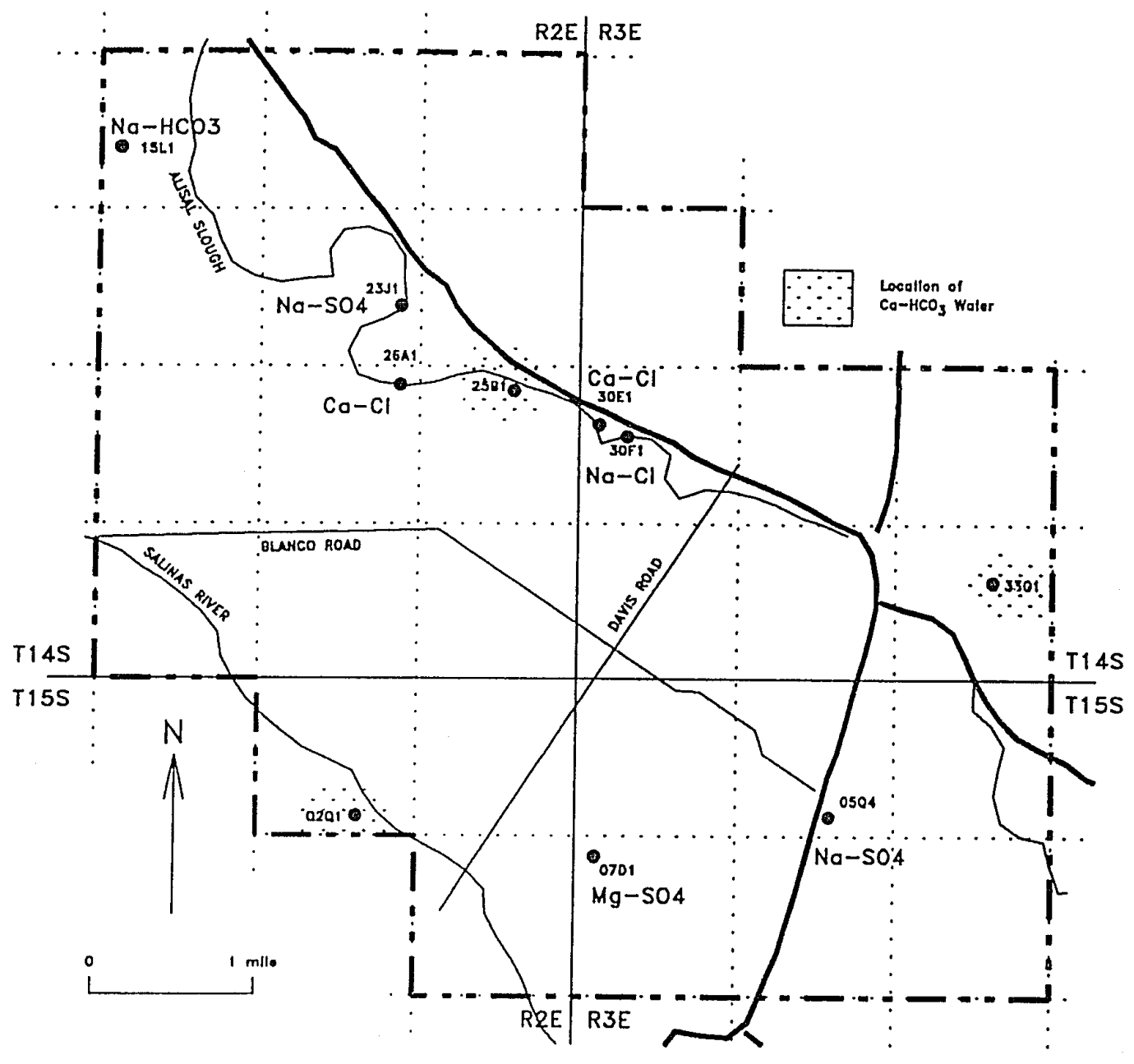

Figure 41. Water zonation map for 1962 showing the location of calciumbicarbonate ground water type. Wells where calciumbicarbonate water is not the predominant water type are labelled with the predominant cation-anion pair. Filled circles show where the water quality samples were collected. 


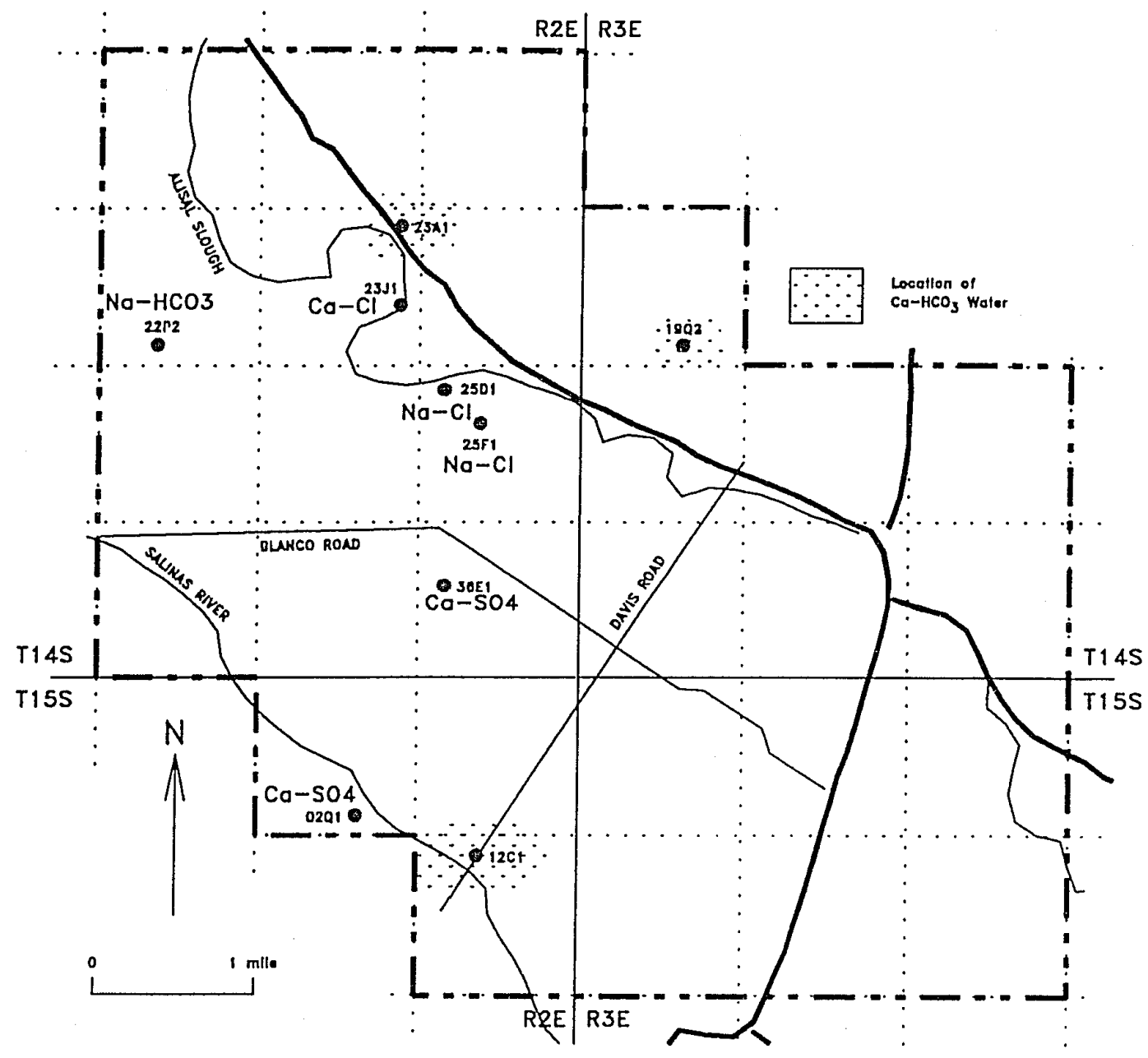

Figure 42. Water zonation map for $1972-73$ showing the Tocation of calcium-bicarbonate ground water type. Wells where calciumbicarbonate water is not the predominant water type are labelled with the predominant cation-anion pair. Filled circles show where the water quality samples were collected. 


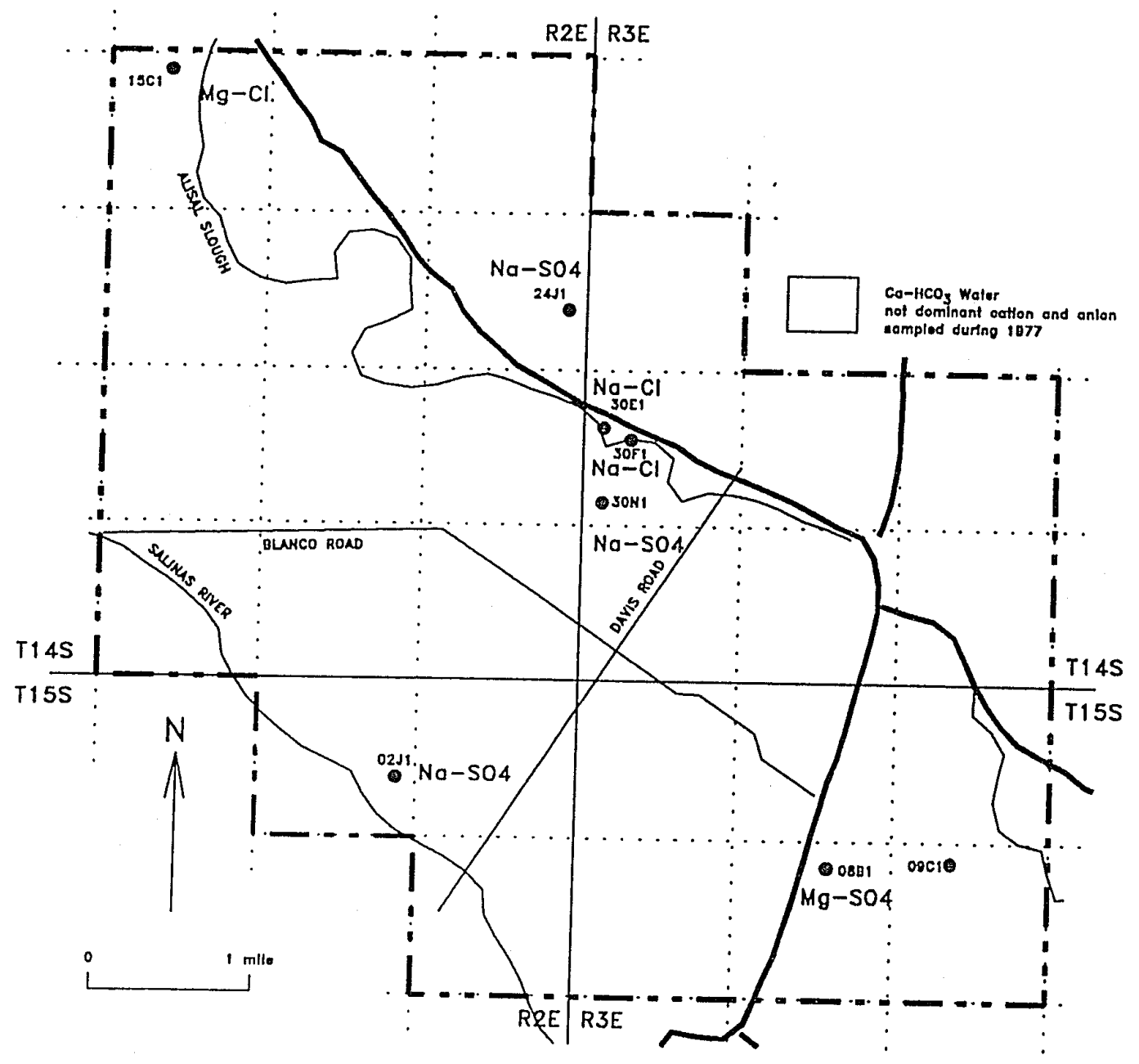

Figure 43. Water zonation map for 1977 showing the predominant cationanion pair. Filled circles show where the water quality samples were collected and labels show the water type. 

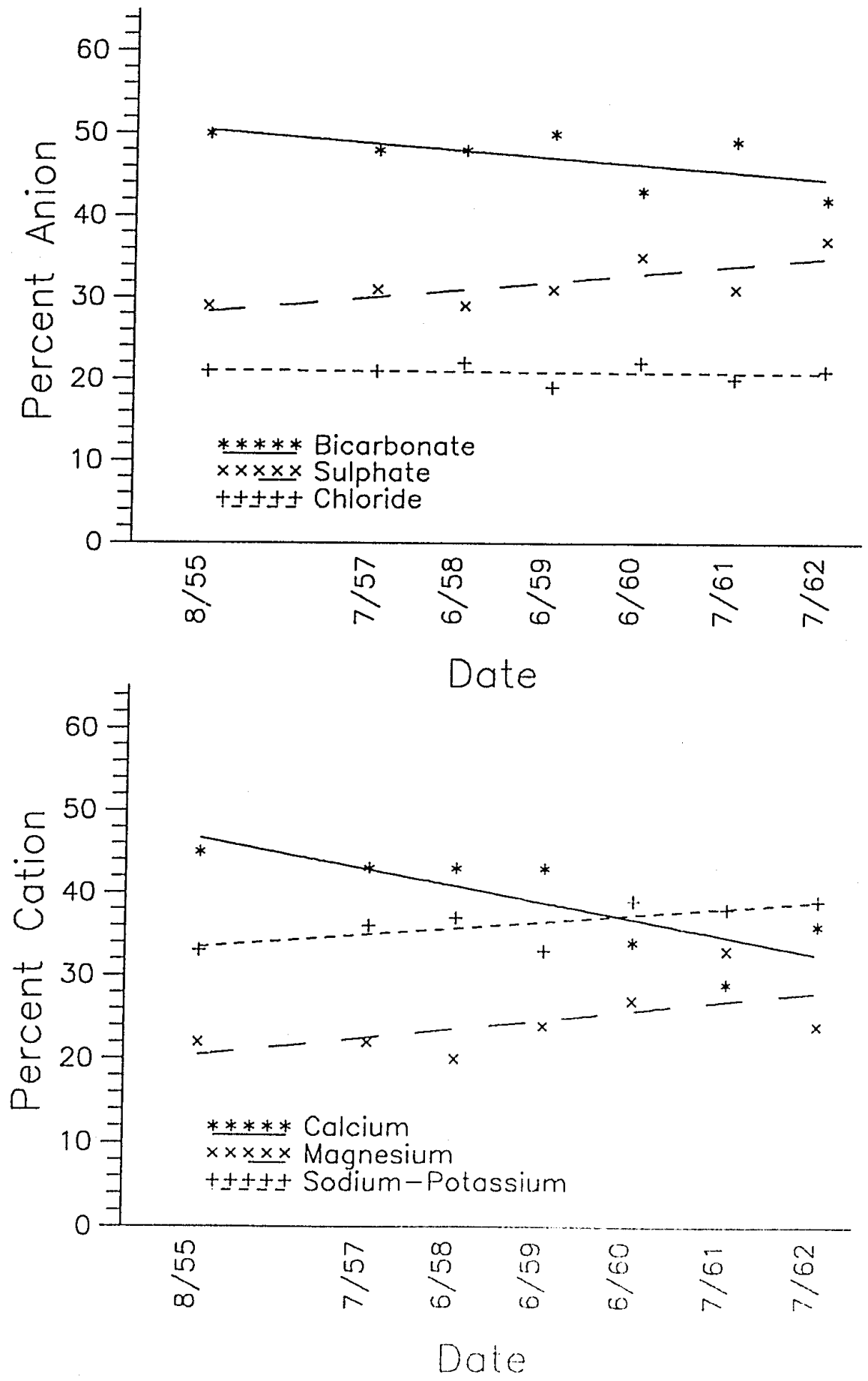

Figure 44. Major anion versus time (top) and cation versus time (bottom) plots for Well 14S/2E-15L1. 

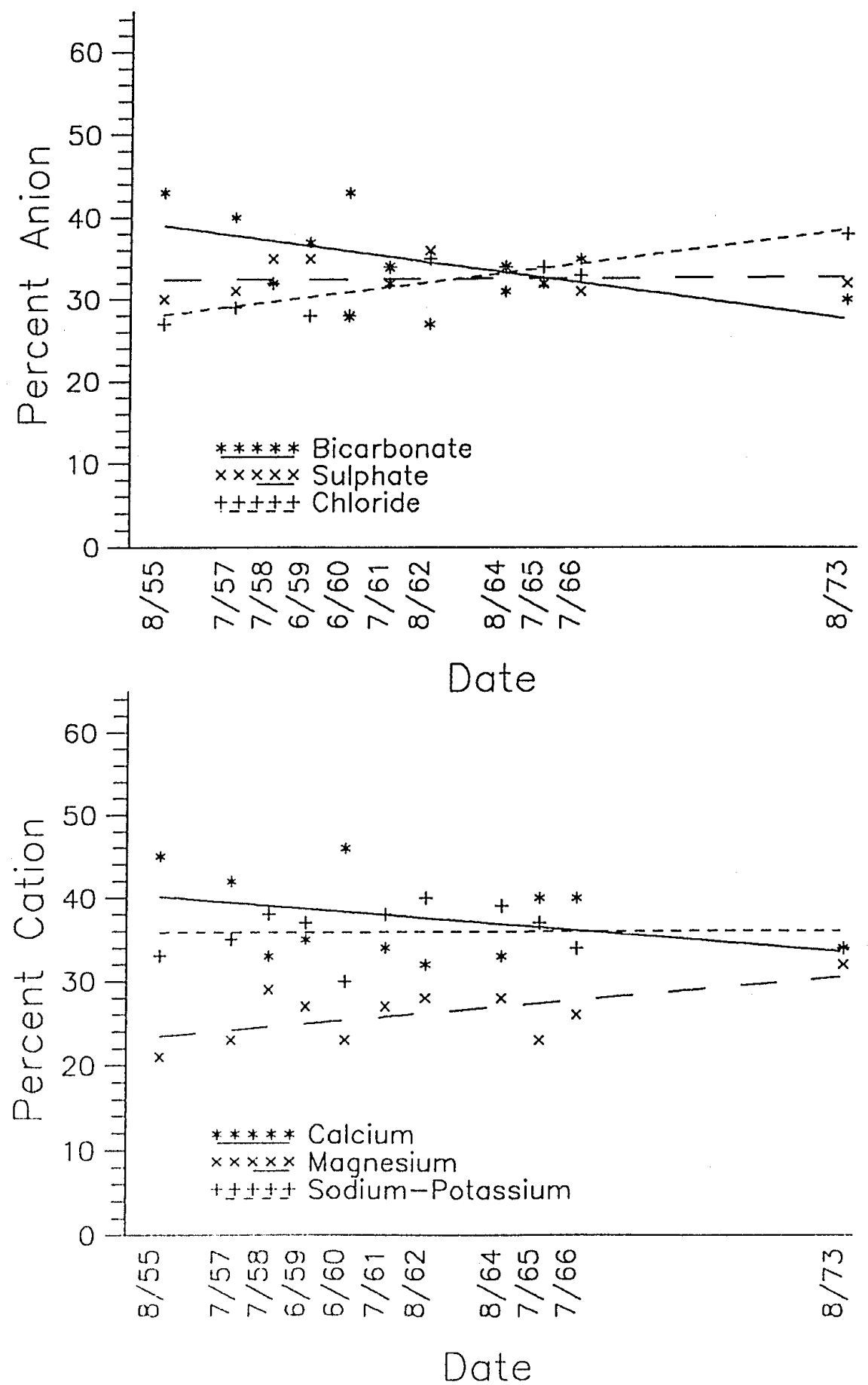

Figure 45. Major anion versus time (top) and cation versus time (bottom) plots for Well 14S/2E-23J1. 

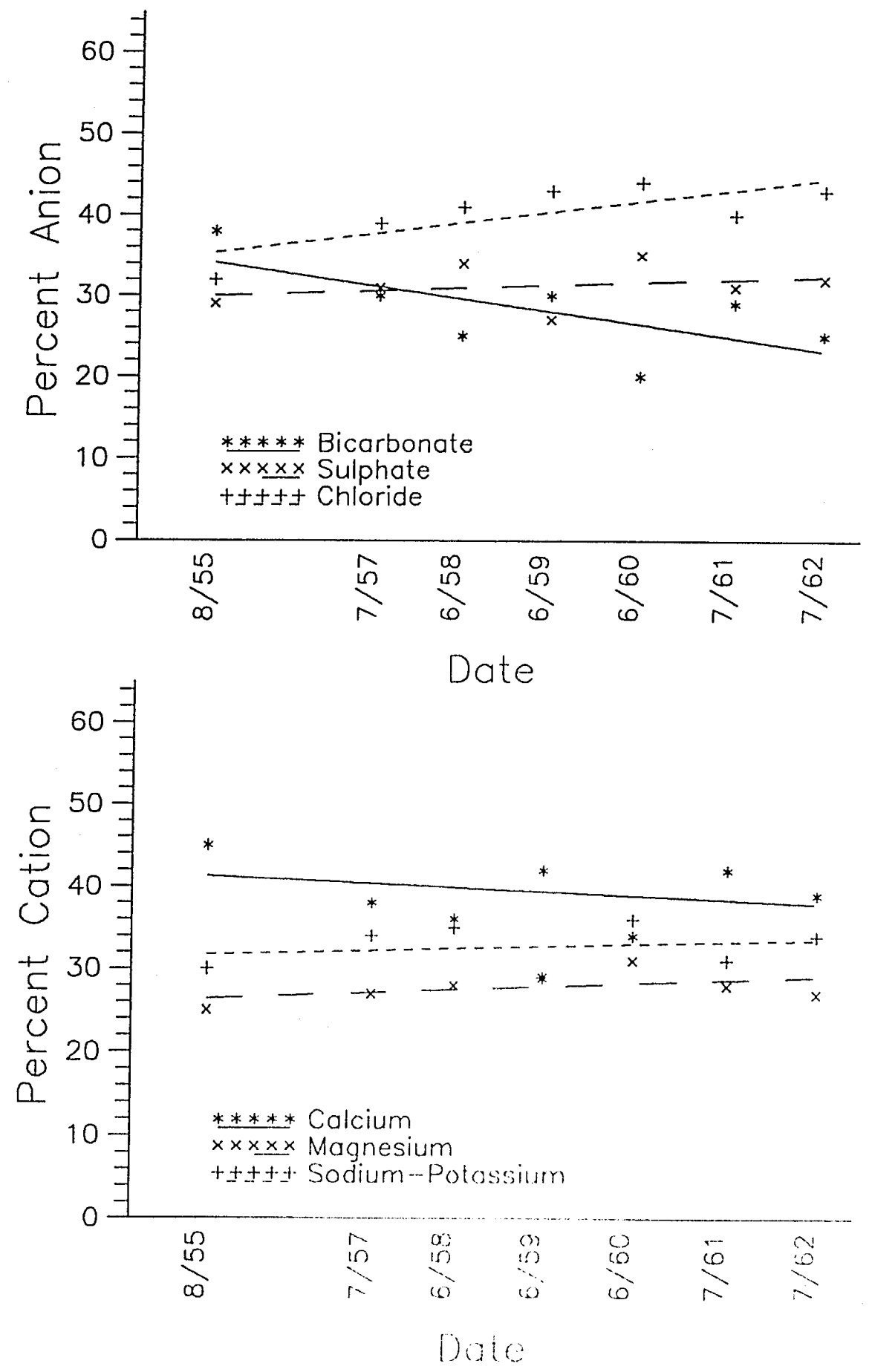

Figure 46. Major anion versus time (top) and cation versus time (bottom) plots for Well 14S/2E-26Al. 

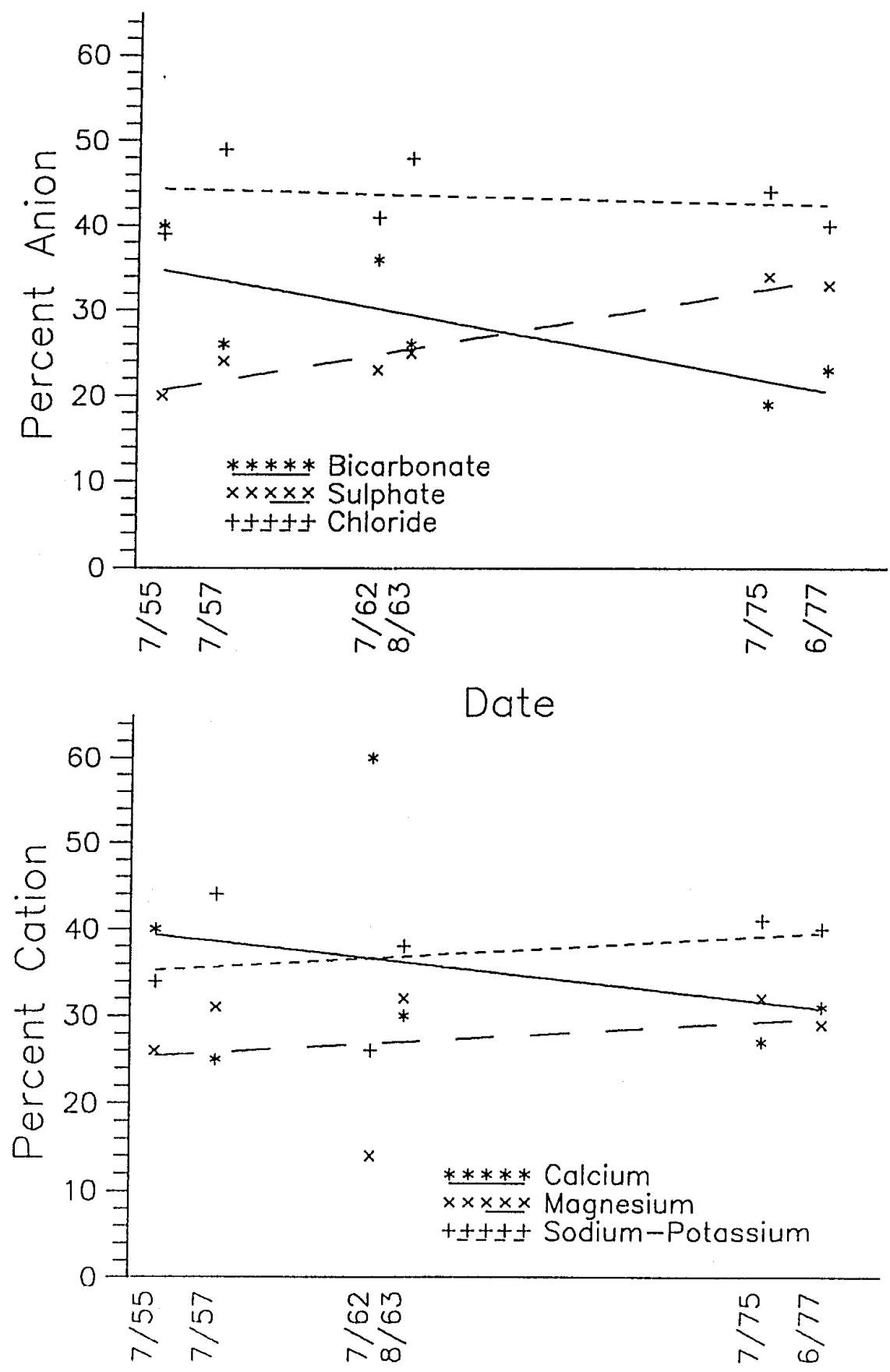

Date

Figure 47. Major anion versus time (top) and cation versus time (bottom) plots for Well 14S/3E-30E1. 


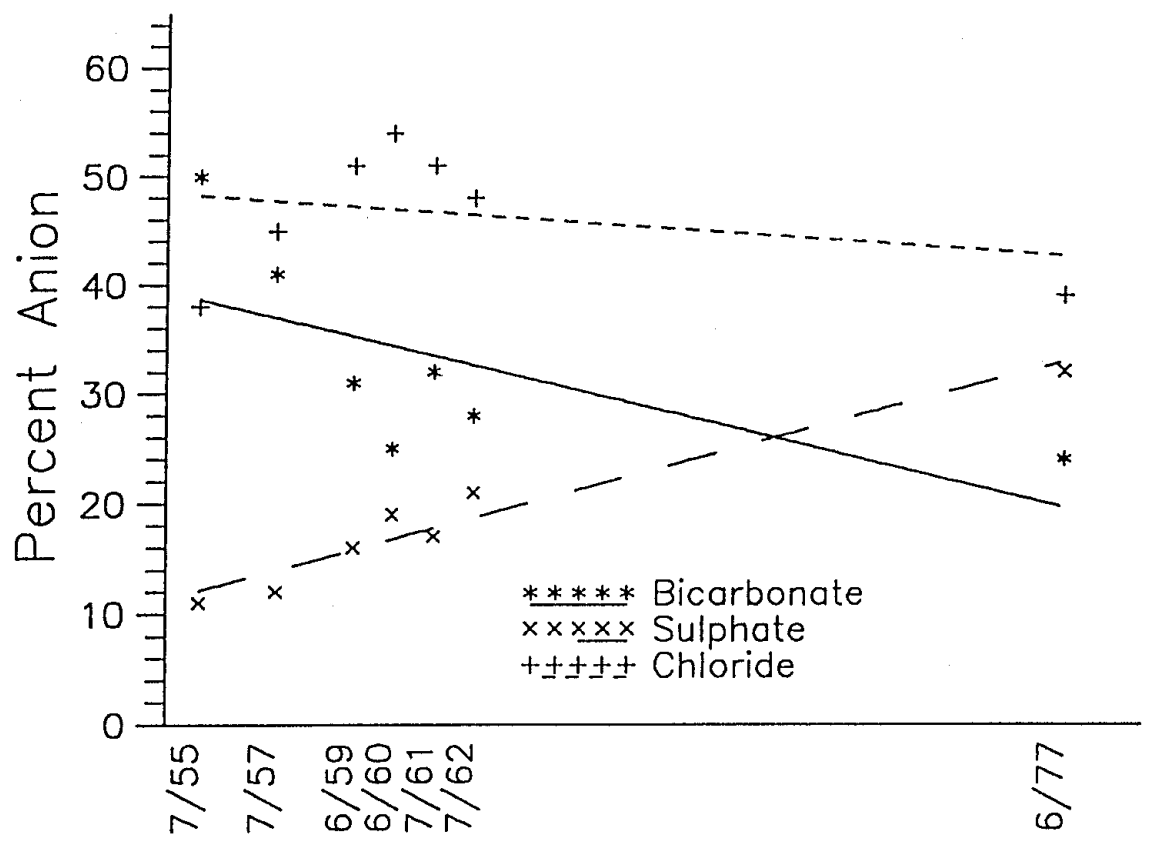

Date

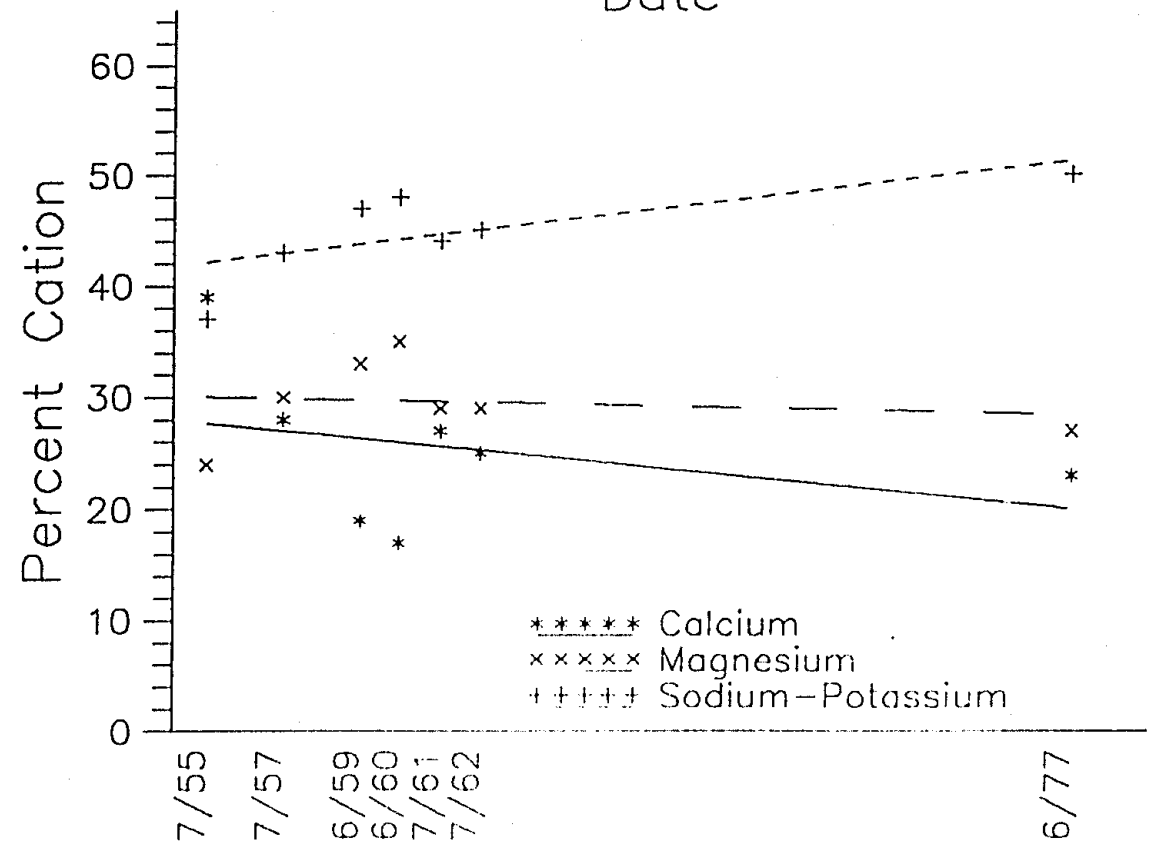

Dote

Figure 48. Major anion versus time (top) and cation versus time (bottom) plots for Well 14S/3E-30F 1 . 

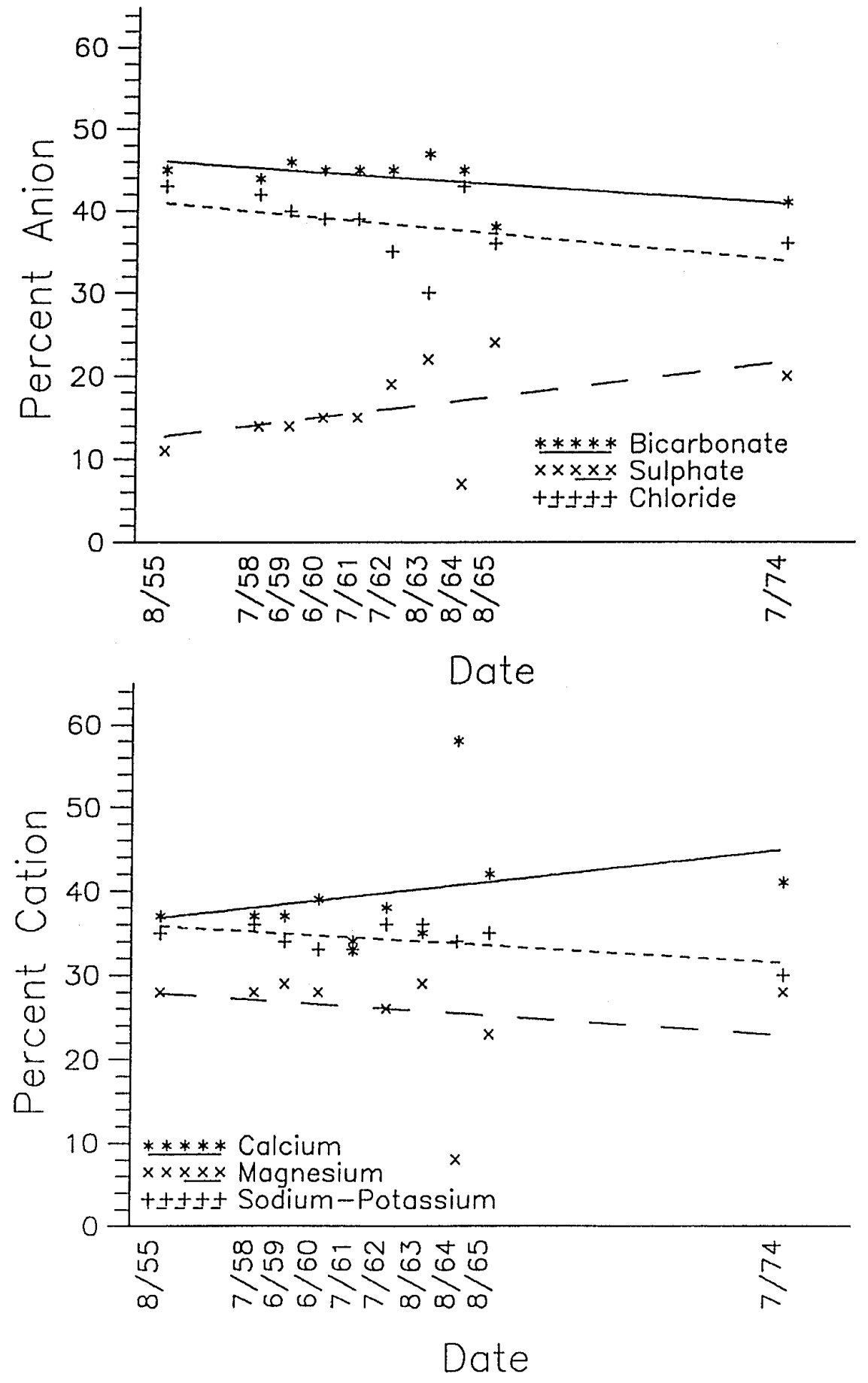

Figure 49. Major anion versus time (top) and cation versus time (bottom) plots for Well 14S/3E-33Gl. 

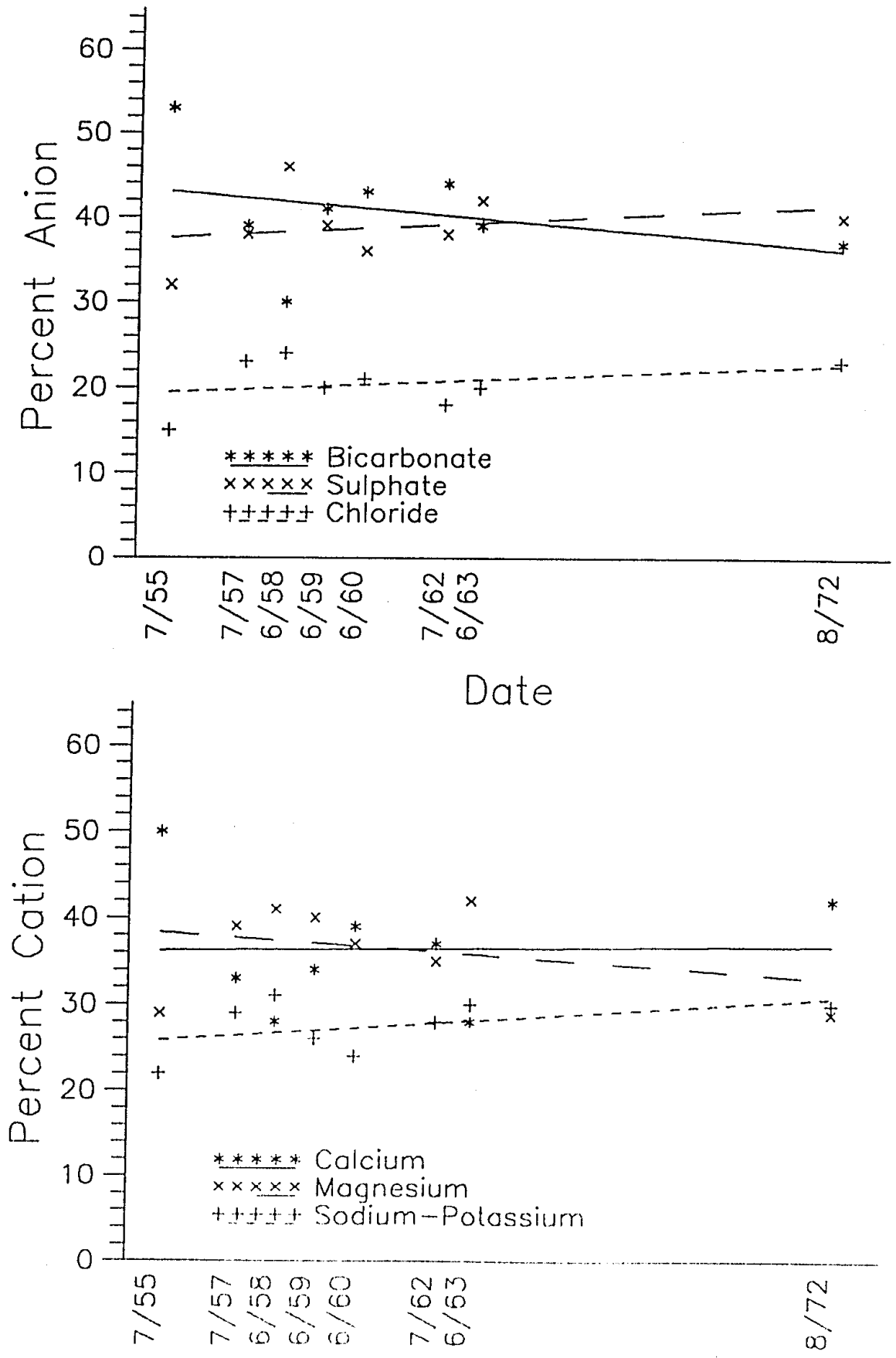

Date

Figure 50. Major anion versus time (top) and cation versus time (bottom) plots for Well 15S/2E-02Q1. 

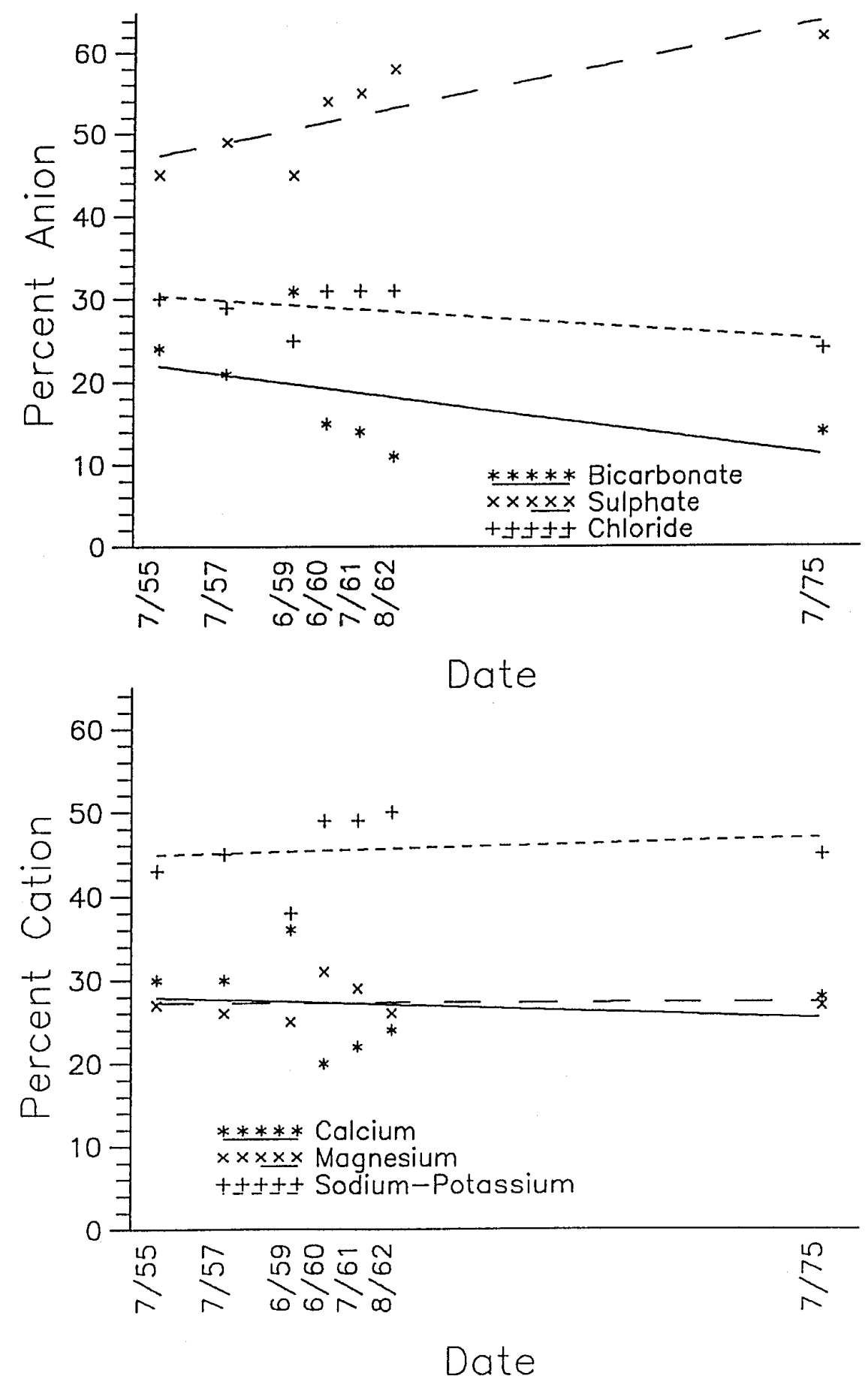

Figure 51. Major anion versus time (top) and cation versus time (bottom) plots for Well 15S/3E-05Q4. 

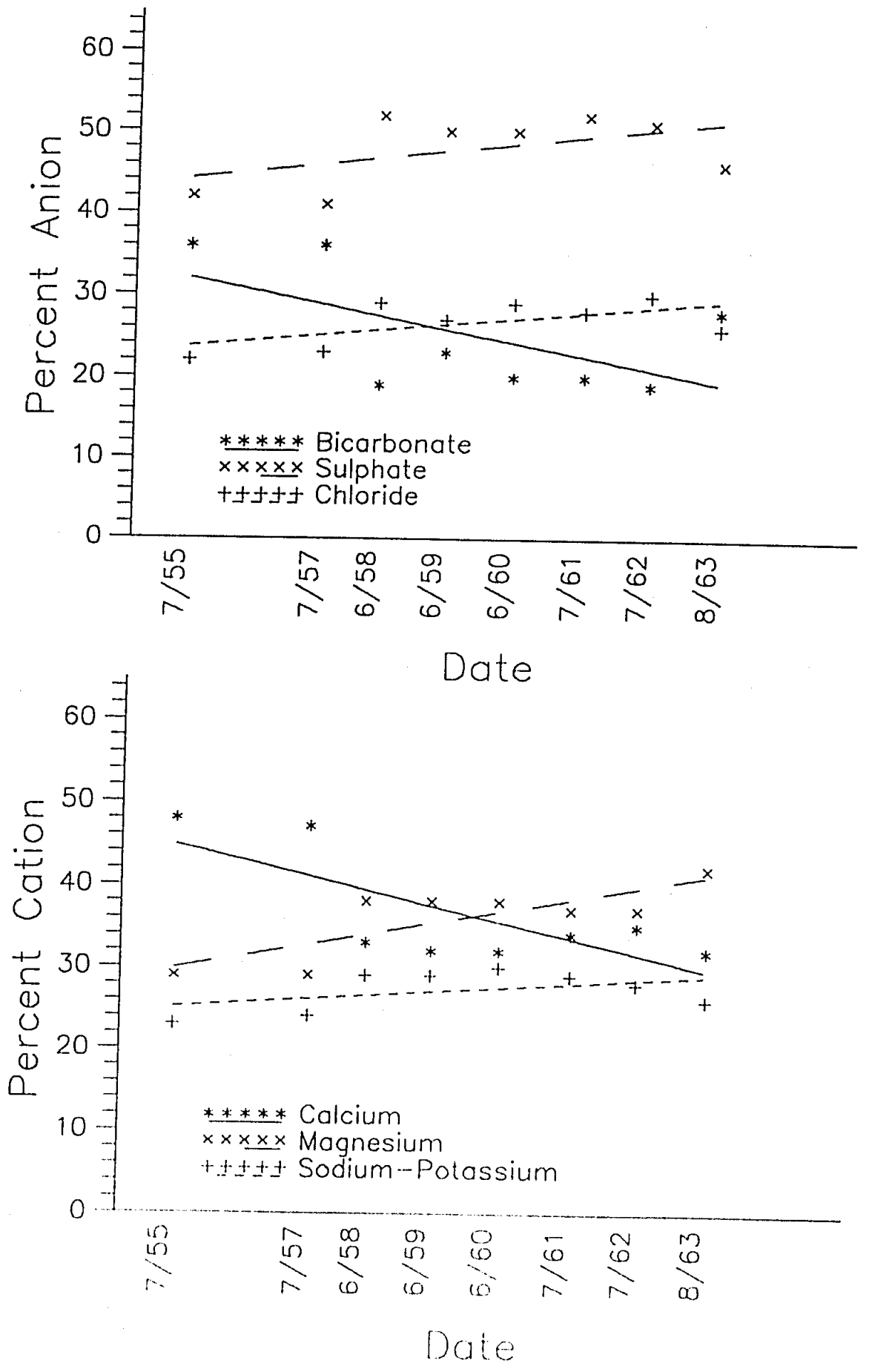

Figure 52. Major anion versus time (top) and cation versus time (bottom) plots for Well 15S/3E-07D1. 
bicarbonate anion and sulphate anion over time. Five of the wells show an inverse relationship and four of the wells show a direct relationship between the bicarbonate anion and the chloride anion. The change in the percentage of major cations versus time shows a direct relationship between the magnesium cation and sodium+potassium cations and an inverse relationship between the sodium+potassium and magnesium cations with the calcium cation.

\section{Piezometric Surface Elevation}

Contoured November or December measurements of the piezometric surface elevation of the "180-foot" pressure aquifer at five-year intervals from 1950 to 1965 show a local ground water gradient to the northwest (Figs. 53 to 56). In 1970, a ground water depression existed in the west-central area, probably due to a recent pumping episode (Fig. 57). The overall local ground water gradient direction remained northwesterly, toward the depression. In 1975, a ground water depression existed in the east-central area, again, probably due to pumping (Fig. 58). The local ground water gradient was toward this depression. In 1980 and 1985, the local ground water gradient was to the north-northwest and northwest, respectively (Figs. 59 and 60). In 1990, a northwest-trending mound in the south-central area and local depressions in the northwest and southwest areas created local ground water gradients to the southwest and northwest (Fig. 61).

The hydraulic gradient in the study area (Figs. 53 to 60) was measured to be: $0.0013 \mathrm{ft} / \mathrm{ft}$ in $1950,0.0007 \mathrm{ft} / \mathrm{ft}$ in $1955,0.0004 \mathrm{ft} / \mathrm{ft}$ 


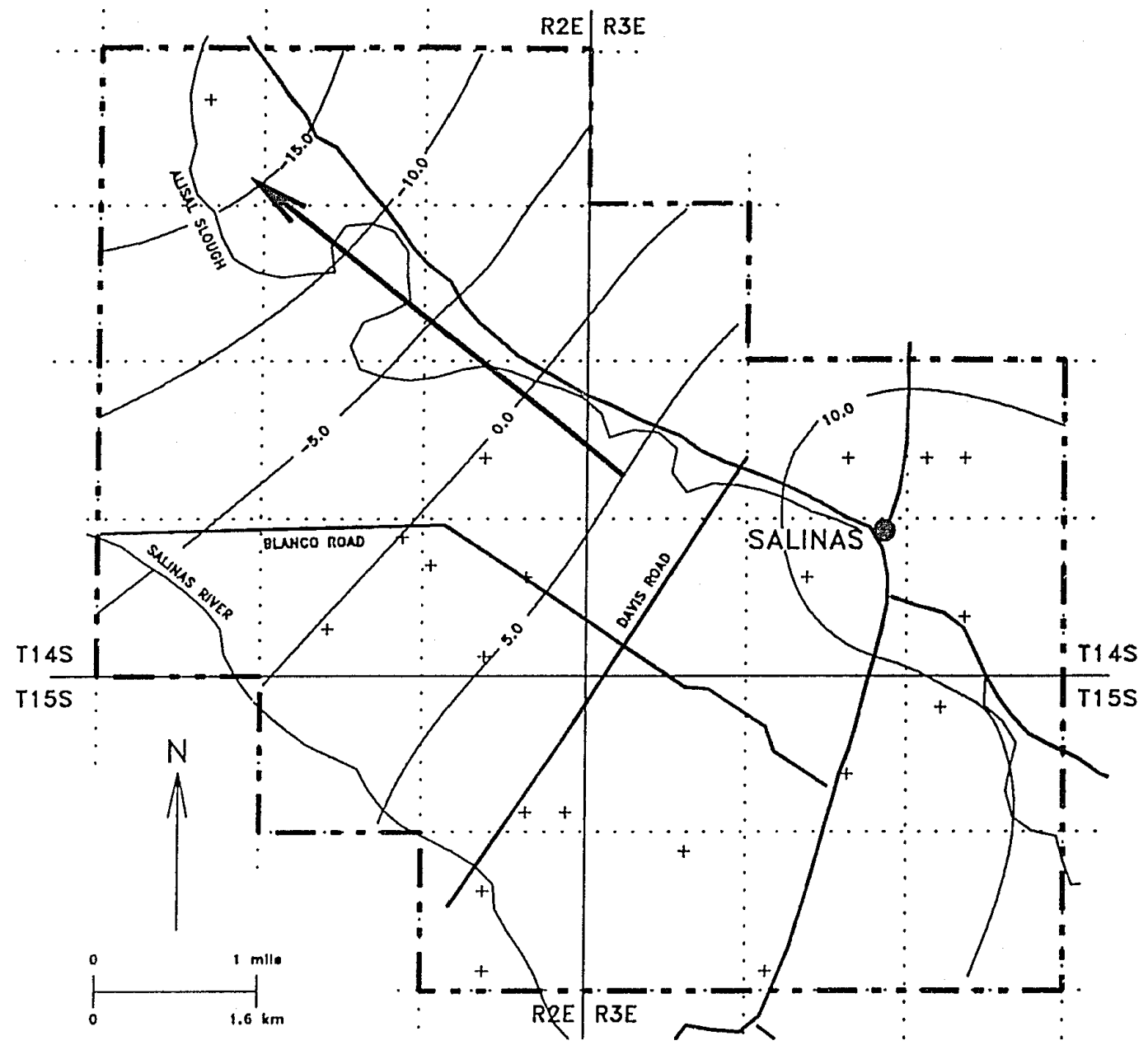

Figure 53. Piezometric surface elevation contours from well water collected in Fall 1950, showing the location and direction (arrow) of the calculated ground water gradient. 


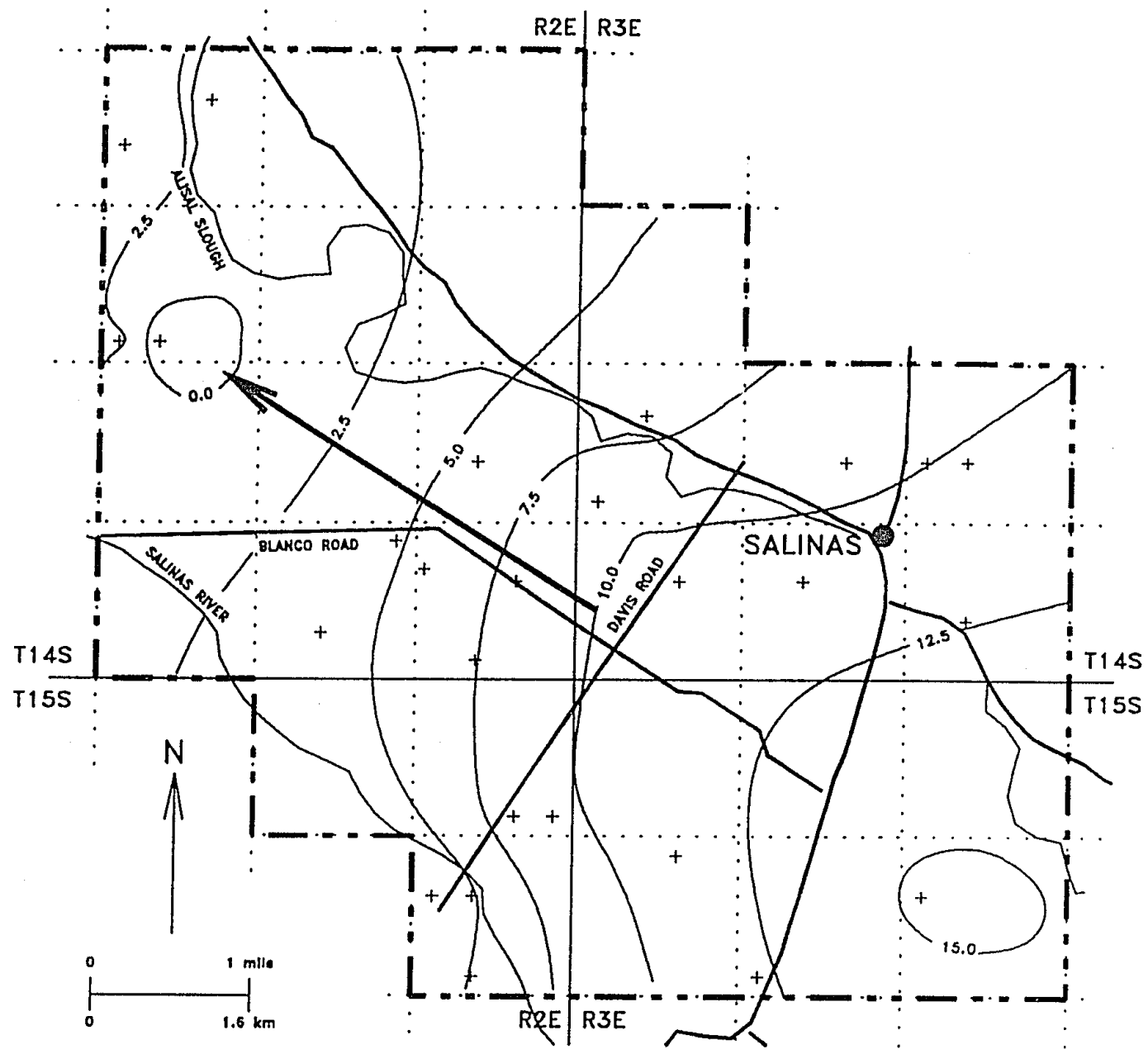

Figure 54. Piezometric surface elevation contours from well water measurements collected in Fall 1955, showing the location and direction (arrow) of the calculated ground water gradient. 


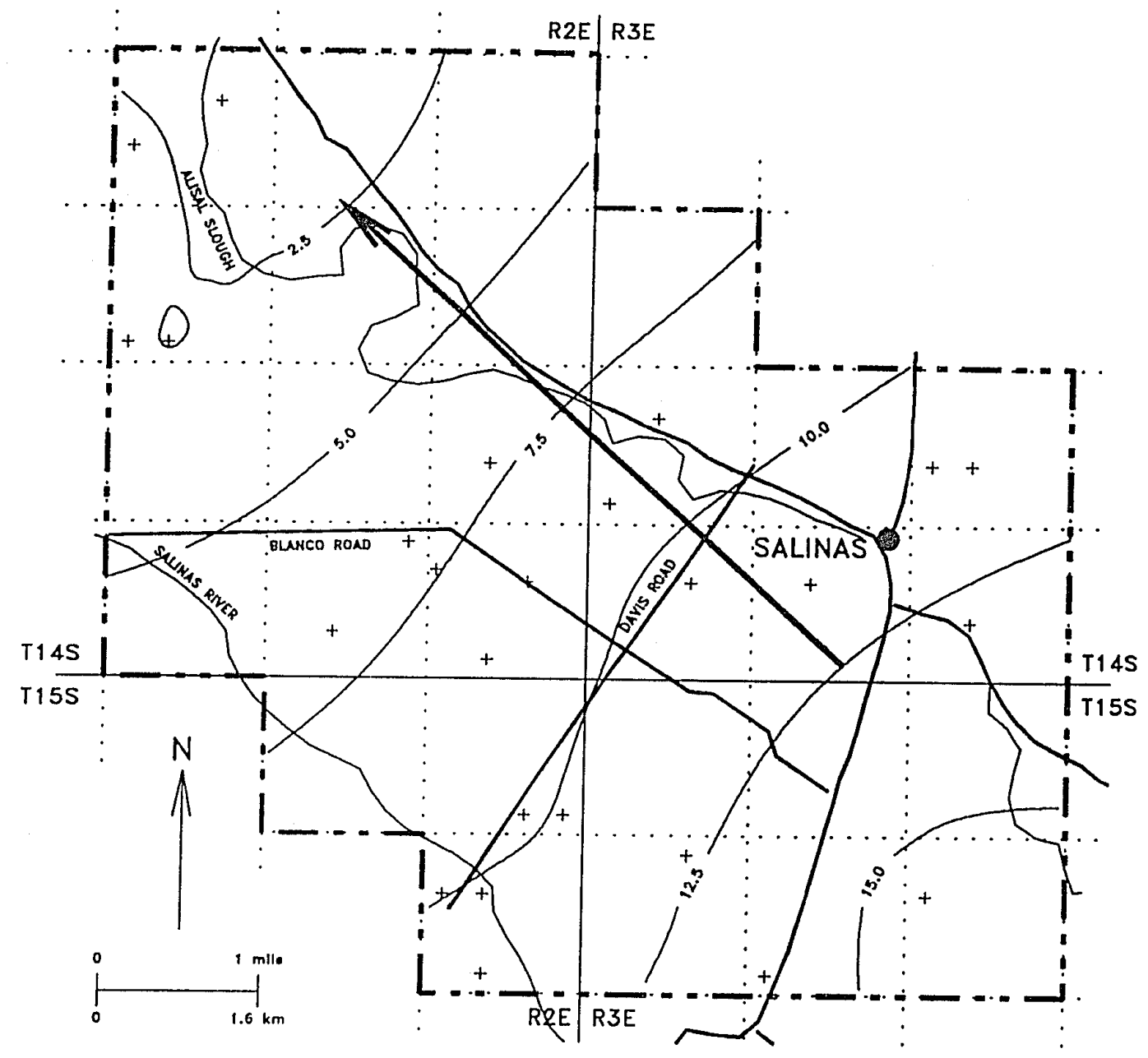

Figure 55. Piezometric surface elevation contours from well water measurements collected in Fa7l 1960, showing the location and direction (arrow) of the calculated ground water gradient. 


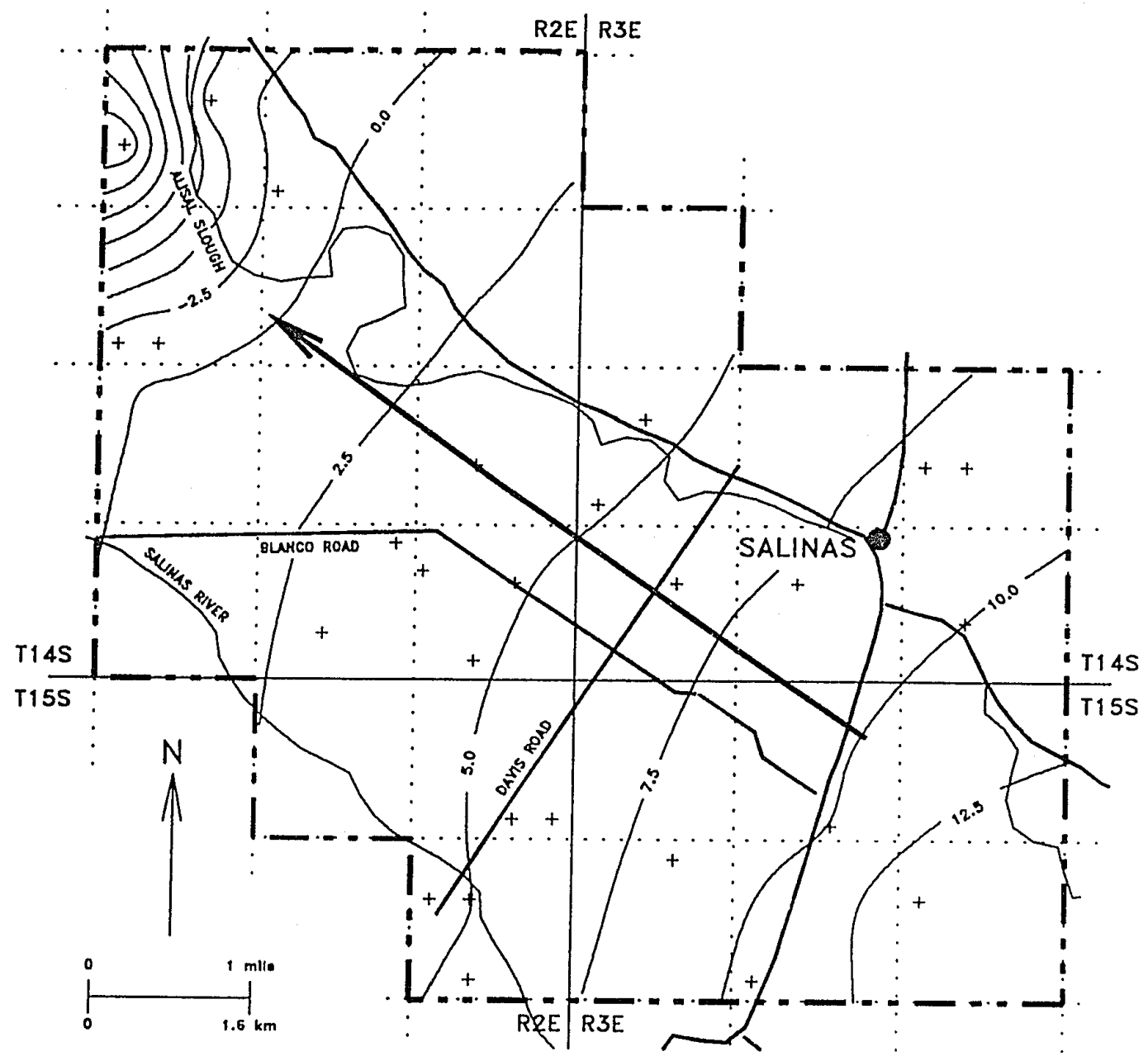

Figure 56. Piezometric surface elevation contours from well water measurements collected in Fall 1965, showing the location and direction (arrow) of the calculated ground water gradient. 


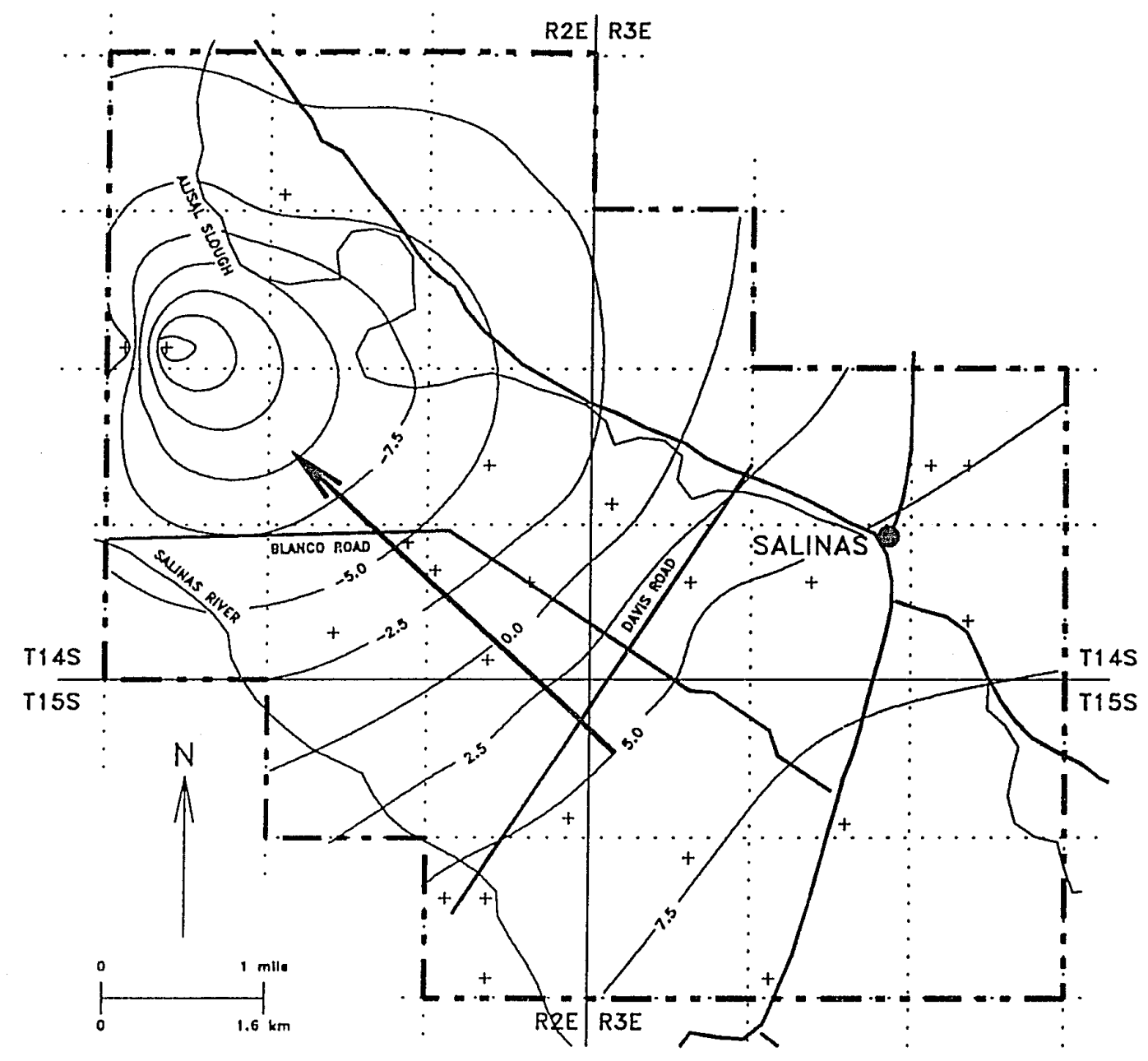

Figure 57. Piezometric surface elevation contours from well water measurements collected in Fall 1970, showing the location and direction (arrow) of the calculated ground water gradient. 


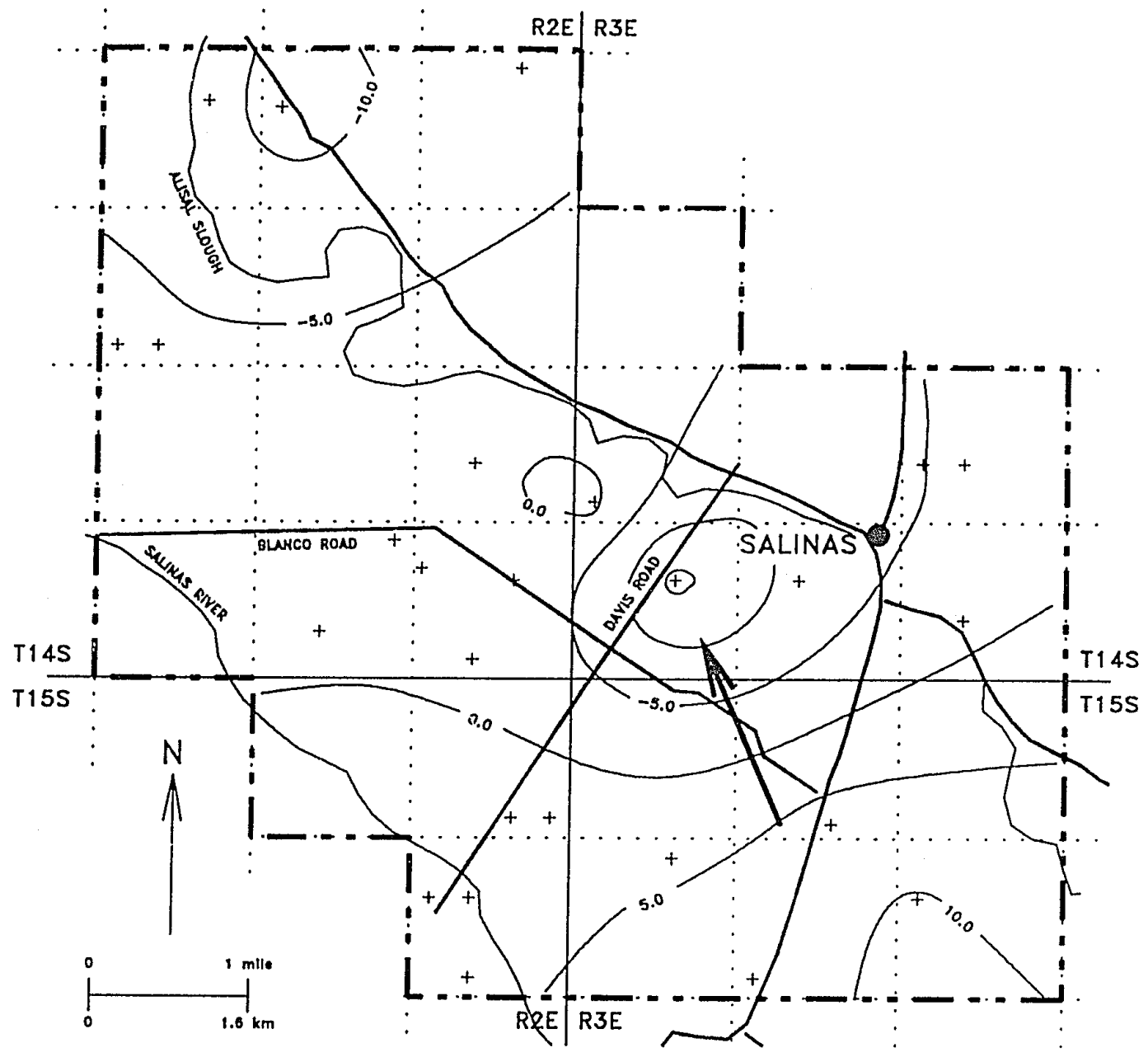

Figure 58. Piezometric surface elevation contours from well water measurements collected in Fal1 1975, showing the location and direction (arrow) of the calculated ground water gradient. 


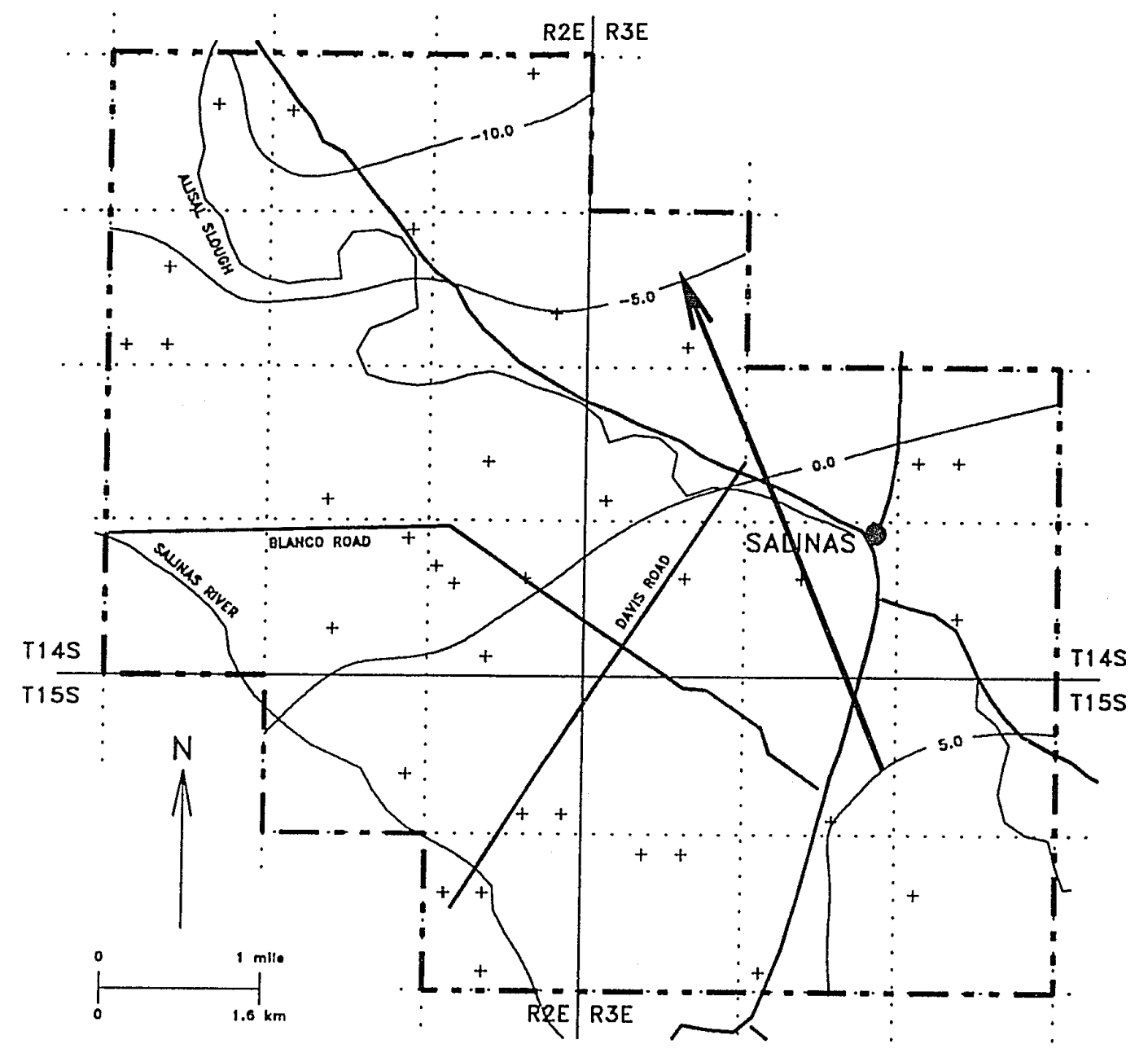

Figure 59. Piezometric surface elevation contours from well water measurements collected in Fall 1980, showing the location and direction (arrow) of the calculated ground water gradient. 


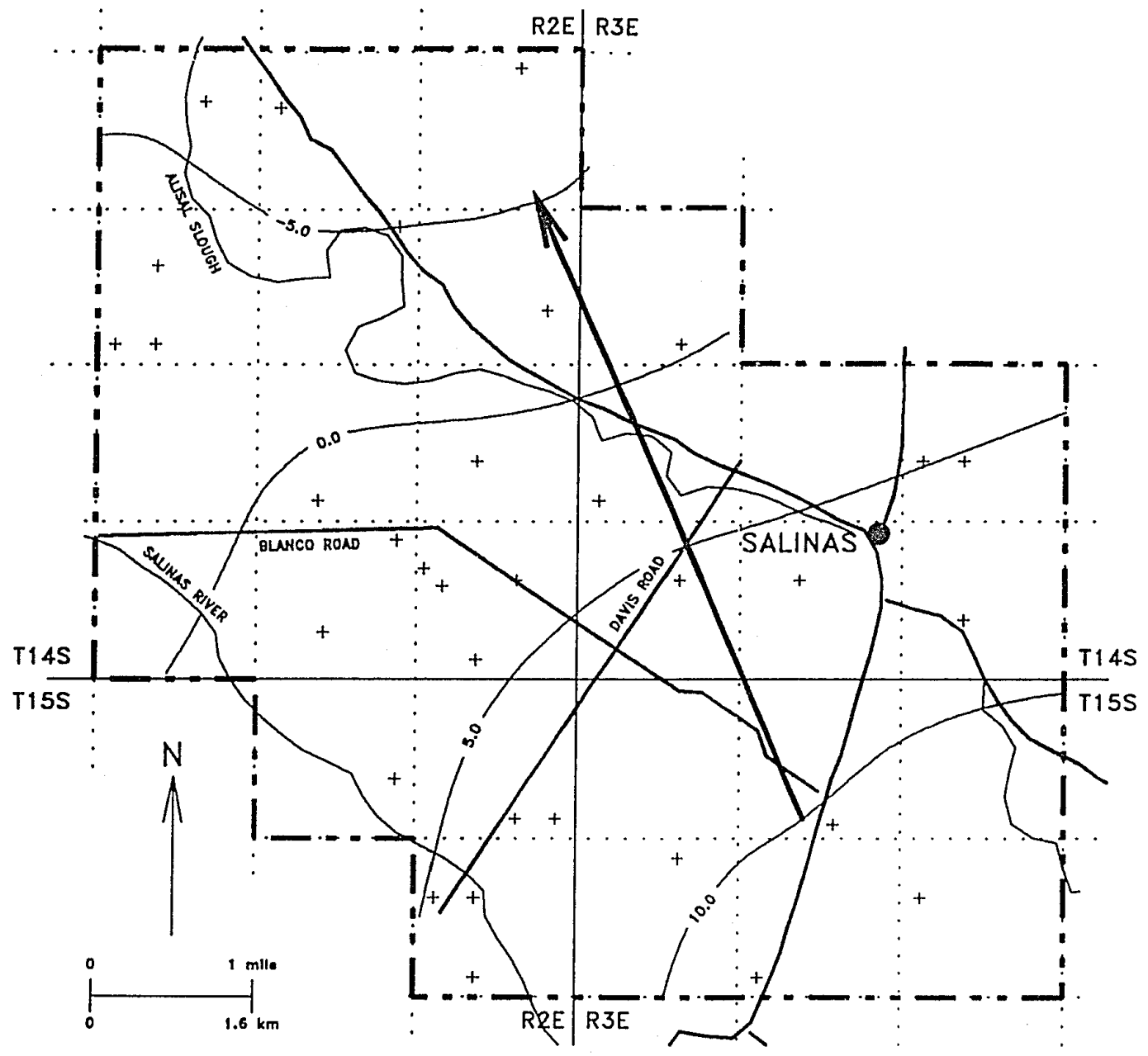

Figure 60. Piezometric surface elevation contours from well water measurements collected in Fall 1985, showing the location and direction (arrow) of the calculated ground water gradient. 


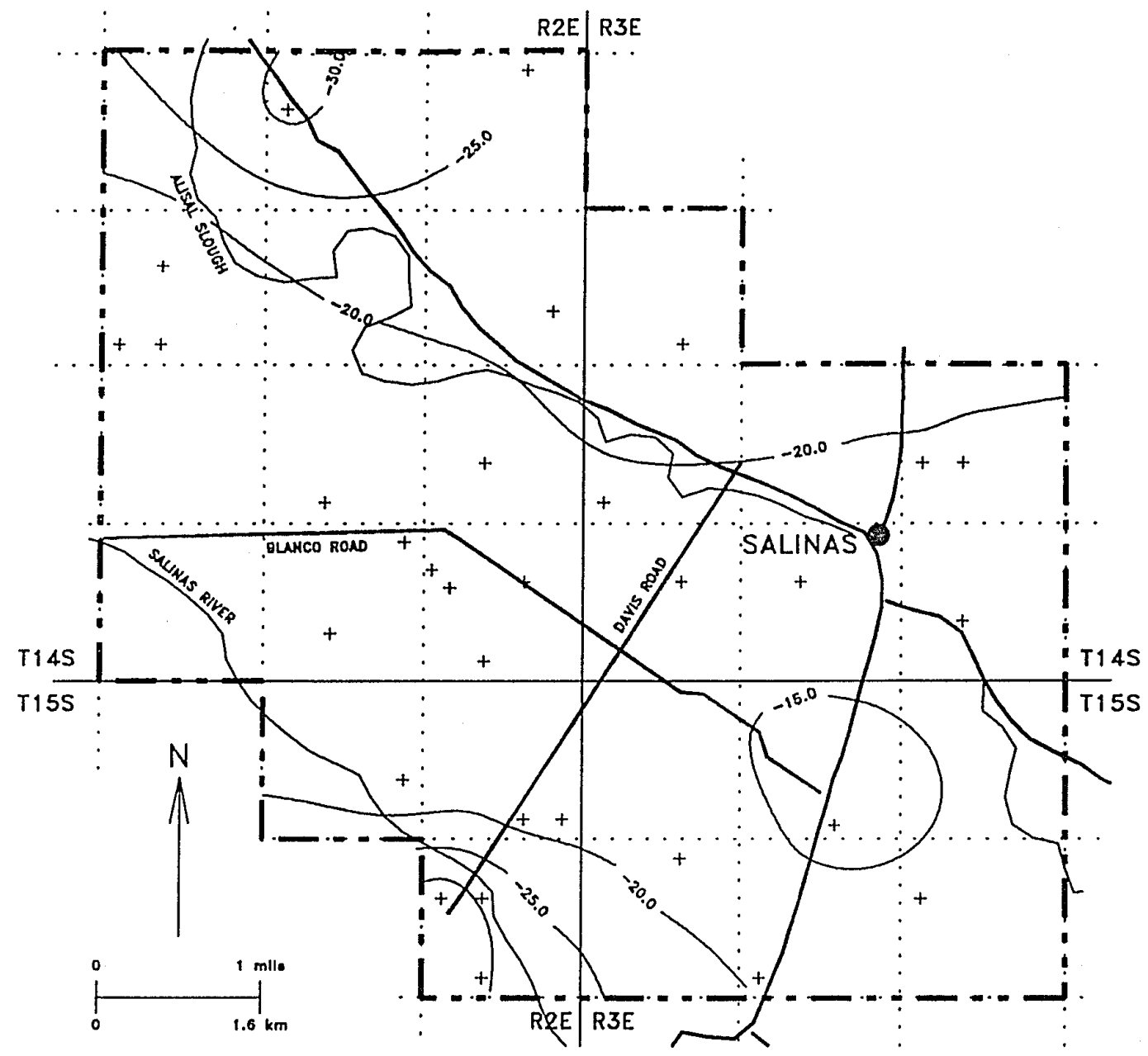

Figure 61. Piezometric surface elevation contours from well water measurements collected in Fall 1990. The ground water gradient was not calculated for 1990 . 
in $1960,0.0004 \mathrm{ft} / \mathrm{ft}$ in $1965,0.0010 \mathrm{ft} / \mathrm{ft}$ in $1970,0.0024 \mathrm{ft} / \mathrm{ft}$ in $1975,0.0006 \mathrm{ft} / \mathrm{ft}$ in 1980, and $0.0007 \mathrm{ft} / \mathrm{ft}$ in 1985 . The gradient was not calculated for 1990 due to the piezometric surface depressions.

Seven hydrographs, spanning between 16 and 40 years of piezometric surface elevation measurements (Appendix 5), show a decline in the piezometric surface through the summer (August data), recharge during November and December, and a maximum elevation during March (Figs. 62 to 65 and Appendix 5). The annual piezometric surface decline during the summer is attributed to agricultural irrigation. Recovery occurred in all seven wells during the fall months (November and December data) and is attributed to a decrease in pumping of the ground water for irrigation purposes and, possibly, some rainfall recharge. Piezometric surface elevation fluctuations ranged from 8 to $33 \mathrm{ft}$ ( 2 to $10 \mathrm{~m}$ ) between the summer and winter measurements. The highest piezometric surface elevations occurred in five of the wells that had measurements in March. These high elevations are attributed to recharge from precipitation during the rainy winter months and further recovery during periods with little pumpage.

Linear regressions performed on the seven hydrographs showed that the piezometric surface elevation has declined between $0.06 \mathrm{ft} / \mathrm{yr}$ in Wel1 14S/2E-El and $0.74 \mathrm{ft} / \mathrm{yr}$ in Well 14S/3E-30N1. Well El has been measured for the last 17 years and Well 30N1 for the last 35 years. The average decline for the seven wells is $0.36 \mathrm{ft} / \mathrm{yr}$ with measurements spanning between 16 and 40 years duration. The rapid rate of piezometric surface elevation decline in Wells $30 \mathrm{Nl}$ and $09 \mathrm{E} 3$ leveled off 

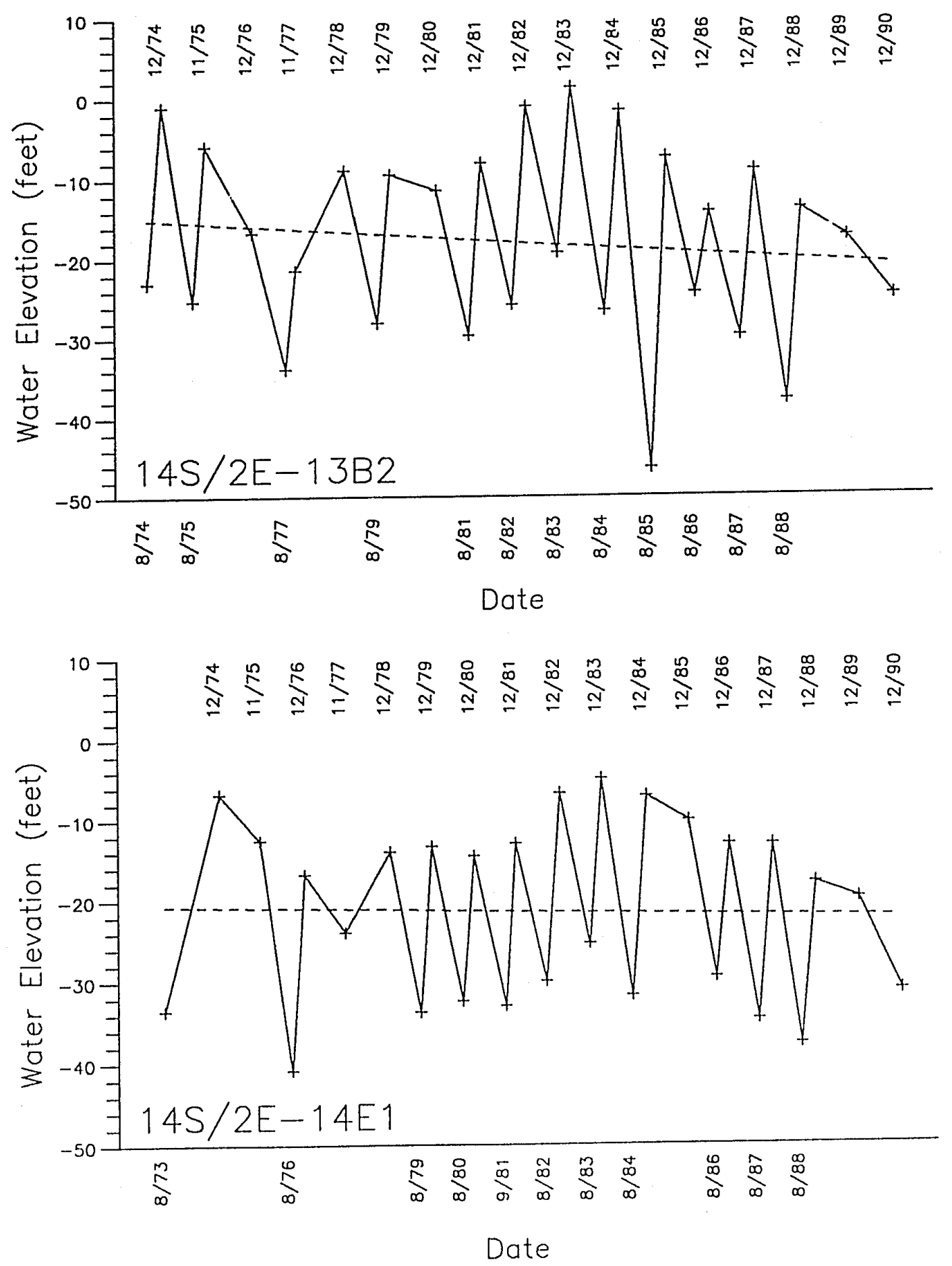

Figure 62. Hydrographs of Wells 14 S/2E-13B2 and 14S/2E-14E1. 

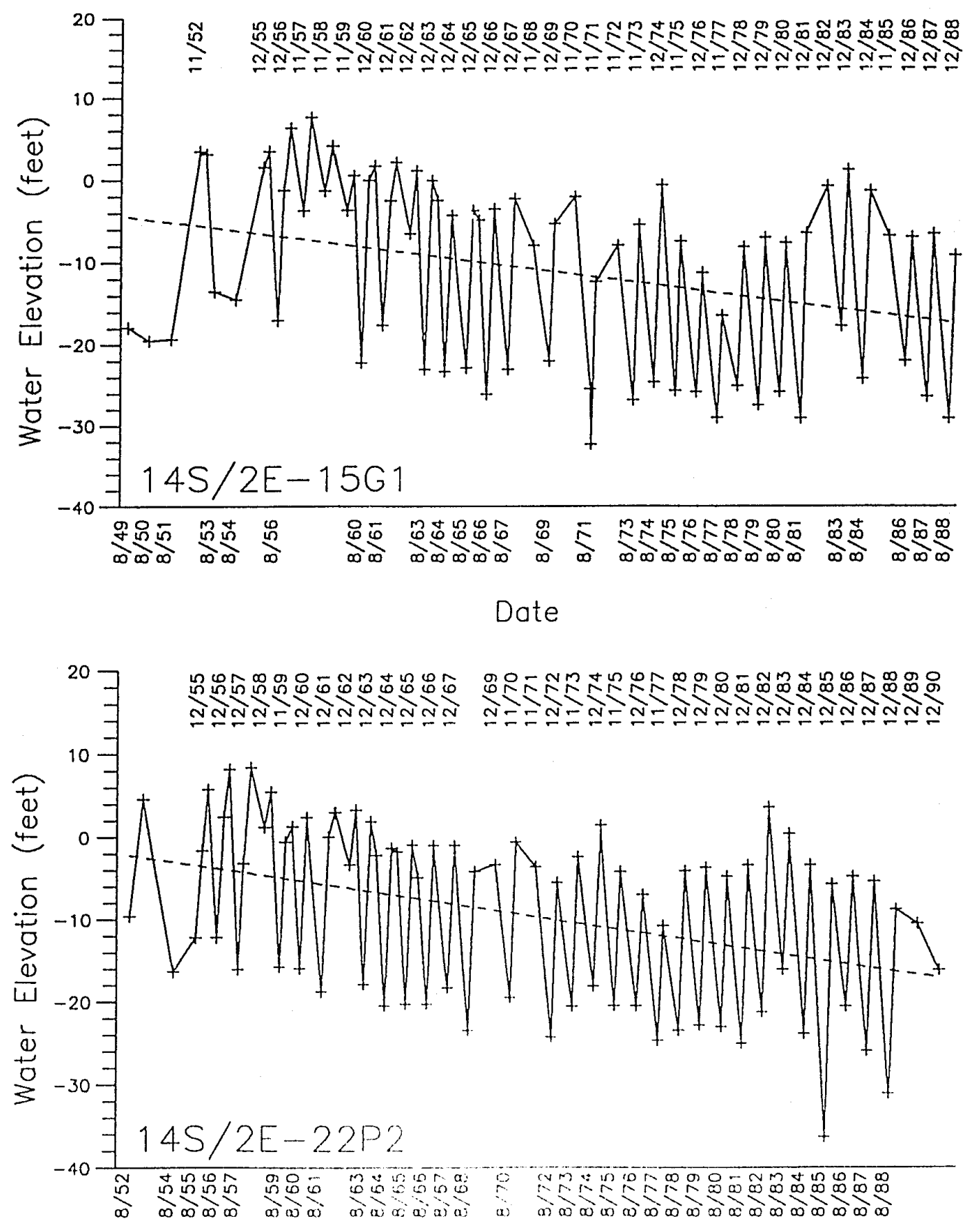

Dole

Figure 63. Hydrographs of Wells 14S/2E-15G1 and 14S/2E-22P2. 

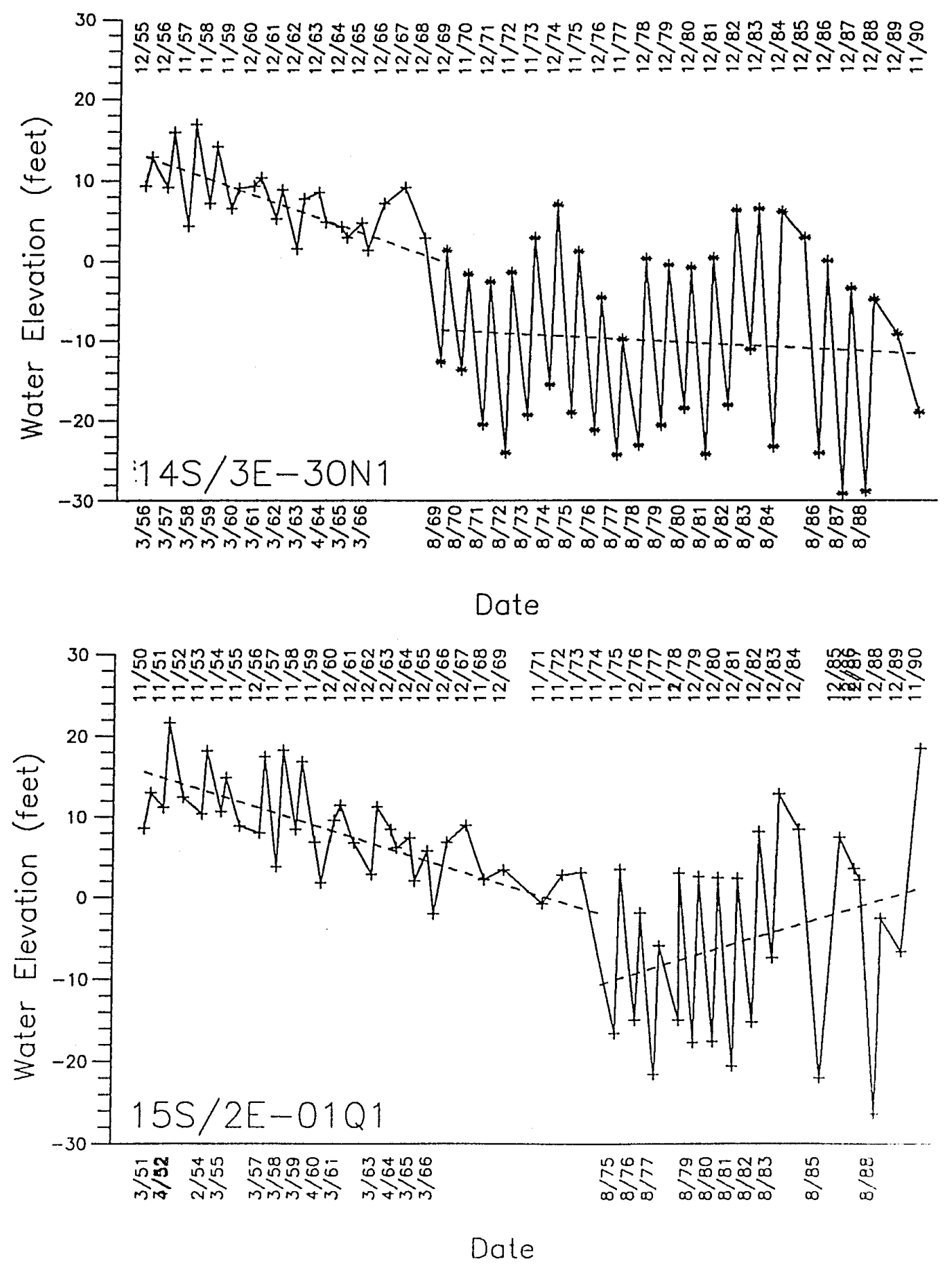

Figure 64. Hydrographs of We11s 14S/3E-30N1 and 15S/2E-01Q1. 


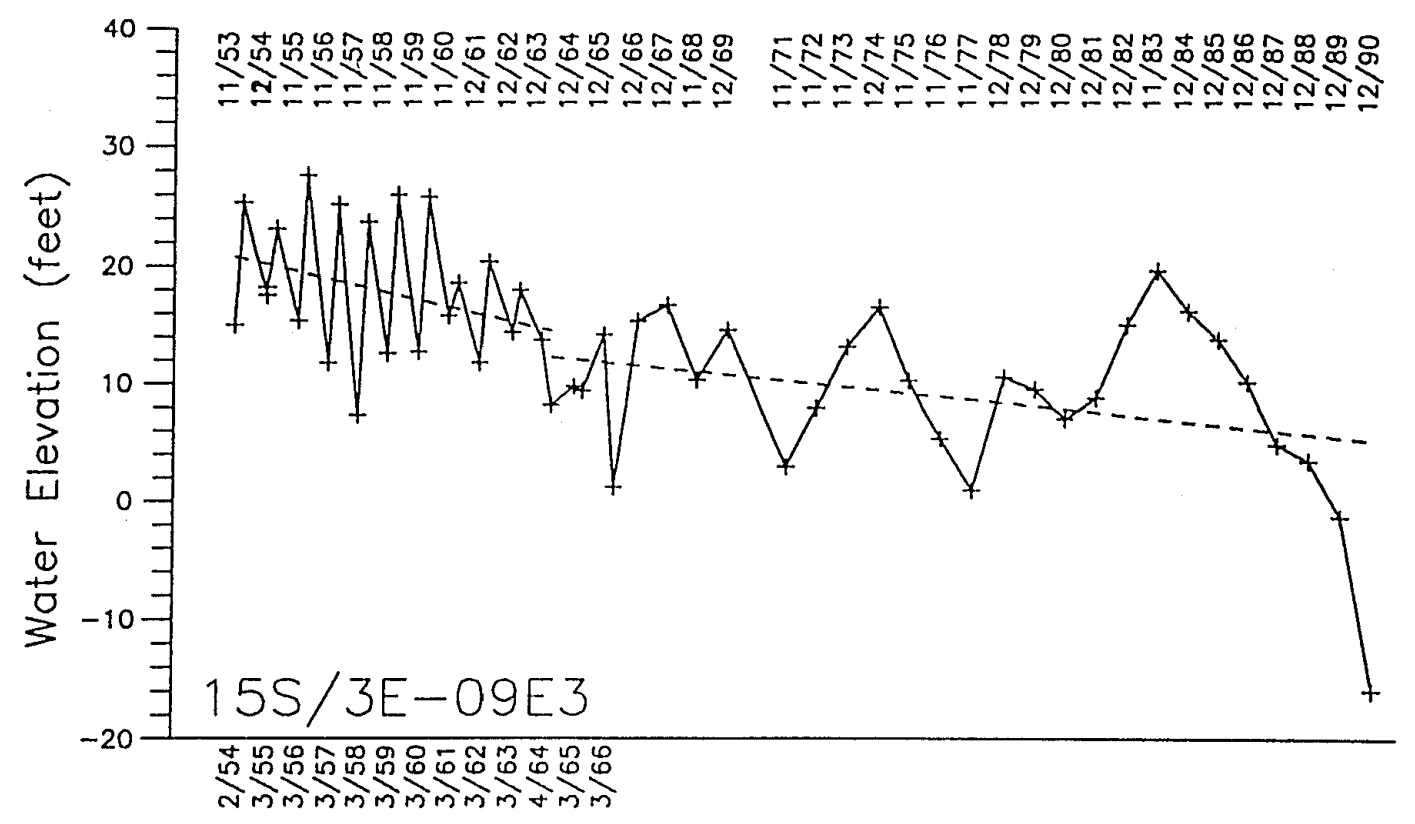

Date

Figure 65. Hydrograph of We 11 15S/3E-09E3. 
in the late 1960 's while the piezometric surface elevation increased rapidly in Well 01Q1. As of now there is no explanation for these changes. 


\section{DISCUSSION}

The "180-foot" pressure aquifer is located predominantly below elevation $-100 \mathrm{ft}(-30 \mathrm{~m})$ in the study area. Here, the "180-foot" pressure aquifer consists of coarse-grained sediment with several thin, discontinuous lenses of fine-grained sediment. However, as shown in Figures 26 through 29, a thick fine-grained deposit has formed between elevation $-310 \mathrm{ft}$ and $0 \mathrm{ft}(-94$ and $0 \mathrm{~m})$ in the central portion of the study area. This probably formed as an estuarine deposit in an environment much like the existing Elkhorn Slough (Tinsley, 1975). The average width, southwest to northeast, of this deposit is about 2 miles $(3 \mathrm{~km})$. The high-salinity ground water is located within the coarsegrained sediment around the perimeter of the estuarine deposit. The coarse-grained sediment is, in general, not directly vertically continuous but shows a combination of lateral and vertical continuity. This is due to the pinching and swelling of the fine-grained deposits located within the coarse-grained sediment. The areas where coarsegrained sediment is vertically connected are (1) in the north-central area near 14S/2E-13, 14, $23 \& 24$, (2) along Davis Road, between $B 1$ anco Road and Highway 183, and (3) in the southeast corner of the study area. The coarse-grained sediment provides a pathway for the downward percolation of agricultural return water.

As shown on cross-sections $A-A^{\prime}, B-B^{\prime}, C-C^{\prime}$, and $D-D^{\prime}$ (Figs. 26, 27 , and 28), the base of the Salinas aquiclude, composed of fine-grained sediment, occurs about $100 \mathrm{ft}(30 \mathrm{~m})$ below sea level. This correlates fairly well with Tinsley's location of the base, $-150 \mathrm{ft}(-46 \mathrm{~m})$, of the 
Holocene marine transgressive deposit identified in the Leonardini well. If the base of the Holocene marine transgression is at about $-100 \mathrm{ft}$ $(-30 \mathrm{~m})$, then most of the "180-foot" pressure aquifer was deposited before $20 \mathrm{ka}$, possibly during the mid-Wisconsinan. The estuarine deposits of blue clay found between elevation $-310 \mathrm{ft}$ and $-100 \mathrm{ft}$ in the center of the study area could also be Wisconsinan. Alternatively, these could be younger deposits filling a channel cut by the Salinas River during the last pleniglacial lowstand of sea level.

I found that the water type throughout the study area was predominantly calcium-bicarbonate in 1955 and during the 1970's became calcium-sodium-sulphate (Appendix 1,2, 3, and 4). Line plots of nine wells where major anions and cations were plotted versus time show an inverse relationship between the bicarbonate anion and the sulphate anion. Sulphate concentrations increased at the expense of bicarbonate. The chloride anion does not show a consistently direct or inverse relationship with either the bicarbonate or sulphate anions. An inverse relationship is shown between the calcium cation and the magnesium and sodiumtpotassium cations. The increased salinity in the ground water is largely the result of the increase in magnesium, sodium, sulphate, and chloride concentrations. There is a slight decrease in calcium and bicarbonate concentrations (Appendix 3 and 4 ).

As shown by the similarity in water chemistry in the stiff diagrams, a correlation can be made between the chemistry of recent ground water and the agricultural return water in Blanco Drain. The sodium-sulphate ground water probably is not due to sea water intrusion. 
However, ground water high in sodium and chloride concentrations may be the result of gradual drainage of connate water from the thick, finegrained estuarine sediment, located in the center of the study area. Saline connate water is not believed to be the sole source of the highsalinity ground water, because the sulphate anion is not a major contributor of salinity in sea water. The zone of high-salinity water in the center of the study area is composed of sodium-chloride water, calcium-chloride water, and sodium-sulphate water. The saline connate water with sodium and chloride ions may have leached from the estuarine deposit and mixed with downward-percolating agricultural return water.

According to Larry Tokiwa (personal communication, 1992) with Western Farm Service, farmers in the Blanco area typically add between 500 and 3000 pounds of gypsum per acre per year to the soil. Gypsum, a hydrous calcium sulphate, aids in the flocculation of soil particles, helps in water penetration, and adjusts the Ph of the soil. Mr. Tokiwa also stated that the farmers typically average 70 to 100 units of potassium sulphate fertilizer. The sulphate anion and potassium cation in the agricultural return water are the result of soil amendment applications.

Contours of the piezometric surface elevation show that the ground water gradient has been northwesterly to northerly between 1950 and 1990. The piezometric surface elevation has historically fluctuated around elevation $0 \mathrm{ft}(0 \mathrm{~m})$, ranging between $-19.5 \mathrm{ft}(-5.9 \mathrm{~m})$ and $11.9 \mathrm{ft}(3.6 \mathrm{~m})$ in $\mathrm{Fall} 1950$ and between $-10.2 \mathrm{ft}(-3.1 \mathrm{~m})$ and $14.0 \mathrm{ft}$ $(4.2 \mathrm{~m})$ in Fall 1985. The abrupt decrease in the piezometric surface 
elevation in Fall 1990 reflects how the local drought has impacted the "180-foot" pressure aquifer. The piezometric surface elevations in Fall 1990 range between -34 to $-14 \mathrm{ft}(-10$ to $-4 \mathrm{~m})$ showing a marked reduction in the piezometric surface elevation since Fall 1985. Unfortunately, this study does not include salinity data after 1977. No correlation could be made between salinity and the recent decrease in the piezometric surface elevation. 


\section{CONCLUSIONS}

The findings from this study support the MCWRA hypothesis that there are discontinuities in the clay aquiclude overlying the "180-foot" pressure aquifer and that agricultural return water is contributing to the high-salinity ground water. Conclusions from this study are:

1. Coarse-grained sediment is vertically continuous from ground surface down to about $340 \mathrm{ft}(104 \mathrm{~m})$ below ground surface in the following three areas: a) in the north-central area near Sections 14S/2E-13, 14, 23 \& 24; b) along Davis Road, between Blanco Road and Highway 183; and c) in the southeast corner of the study area. The coarse-grained sediment provides a pathway for the downward percolation of agricultural return water.

2. The general ground water gradient has been northwesterly to northerly between 1950 and 1990, with occasional pumping troughs influencing the local gradient. The piezometric surface elevations have declined an average of $0.36 \mathrm{ft} / \mathrm{yr}$ $(0.11 \mathrm{~m} / \mathrm{yr})$ since 1949. The maximum drop in the piezometric surface elevation of $0.74 \mathrm{ft} / \mathrm{yr}(0.23 \mathrm{~m} / \mathrm{yr})$ occurred in we11 $14 \mathrm{~S} / 3 \mathrm{E}-30 \mathrm{~N} 1$, located in the high-salinity ground water plume. This increase in the downward vertical hydraulic gradient may account, in part, for the increased downward migration of shallow, high-salinity water. 
3. The historic water type from the 1950's of the study area was calcium-bicarbonate with calcium-sodium-sulphate water located south of the intersection of Davis Road and Blanco Road. The water type in the high-salinity plume area in 1977 was predominantly sodium-sulphate with a small lobe of sodiumchloride water near Davis Road and Highway 183. This water is similar to the sodium-sulphate agricultural return water collected from the Blanco Drain in 1965, indicating its probable origin. The sodium-chloride water, located adjacent to the thick estuarine deposit, may al so have been impacted by gradual drainage of saline connate water from the estuarine clays. The high-salinity plume area ground water is primarily due to an increase in the concentrations of sodium and sulphate and, to a lesser degree, magnesium and chloride. This increase changes the ratio of the major ions with an increase in the magnesium, sodium, sulphate, and chloricie ions and a decrease in calcium and bicarbonate ions. 


\section{REFERENCES CITED}

Beard, C.N., 1941, Drainage development in the vicinity of Monterey Bay, California [Ph.D. thesis]: University of Illinois, Urbana, $123 \mathrm{p}$.

California Division of Water Resources, 1933, Salinas basin preliminary investigation: $35 \mathrm{p}$.

, 1946, Salinas basin investigation, summary report: Bulletin 52-B, $42 \mathrm{p}$.

California Department of Water Resources, 1969, Special investigation, Salinas River Basin: Memorandum Report, January 1969, $67 \mathrm{p}$.

, 1970, Sea-water intrusion, lower Salinas Valley, progress report 1968-1969: prepared for Monterey County Flood Control and Water Conservation District, $28 \mathrm{p}$., Plate 1, 3 sheets; Plate 2, 5 sheets.

, 1973, Seawater intrusion, lower Salinas Valley: Progress Report 1968-1969, 28 p., 2 plates.

California State Water Resources Boârd, 1956, Salinas River basin investigation: Bulletin No, 19, 78 p.

Chin, J.L., 1984, Late Quaternary coastal sedimentation and depositional history, south-central Monterey Bay, California [M.S. thesis]: San Jose State University, San Jose, California, $130 \mathrm{p}$.

Cleath \& Associates, 1991, Hydrogeological investigation Salinas Valley dispersed well system area: unpublished report prepared for Monterey County Water Resources Agency, 8 p., 5 plates.

Dupré, W.R., 1975, Quaternary history of the Watsonville lowlands, north-central Monterey Bay region, California [Ph.D. thesis]: Stanford University, Stanford, California, $145 \mathrm{p}$.

, 1990, Quaternary geology of the Monterey Bay region, California, in Garrison, R.E., Greene, H.G., Hicks, K.R., Weber, G.E., and Wright, T.L., eds., Geology and tectonics of the central California Coast region, San Francisco to Monterey, volume and guidebook: American Association of Petroleum Geologists, Pacific Section, Bakersfield, California, p. 185-192.

Dupré, W.R., Clifton, H.E., and Hunter, R.E., 1980, Modern sedimentary facies of the open Pacific coast and Pleistocene analogs from Monterey Bay, California, in Field, M.E., Bouma, A.H., Colburn, I.P., Douglas, R.G., and Ingle, J.E., eds., Quaternary Depositional Environments of the Pacific Coast: Society of 
Economic Paleontologists and Mineralogists, Pacific Section, Los Angeles, California, p. 105-120.

Dupré, W.R., and Tinsley, J.C., III, 1980, Geology and 1iquefaction potential of northern Monterey County and southern Santa Cruz Counties, California: U.S. Geological Survey Miscellaneous Field Studies Map MF-1199, 2 plates, scale 1:62,500.

Greene, H.G., 1970, Geology of southern Monterey Bay and its relationship to the ground water basin and salt water intrusion: U.S. Geological Survey Open-File Report, $50 \mathrm{p}$.

Greene, H.G., 1977, Geology of the Monterey Bay Region: U.S. Geological Survey Open-File Report 77-718, 347 p., 9 plates.

Greene, H.G., and Clark, J.G., 1979, Neogene paleogeography of the Monterey Bay area, Cal ifornia, in Armentrout, J.M., Cole, M.R., and TerBest, H.Jr., eds., Pacific Coast Paleogeography Symposium 3, Society of Economic Paleontologists and Mineralogists, Pacific Section, Los Angeles, California, p. 277-298.

Luhdorff and Scalmanini, 1986, Well testing and site characterization, Sal inas area: unpublished report prepared for the California State Water Resources Control Board Groundwater "Hot Spots" Project, $22 \mathrm{p}$.

Martin, B.D., and Emery, K.0., 1967, Geology of Monterey Canyon, California, American Association of Petroleum Geologists Bulletin, v. 51, p. 2281-2304.

Monterey County Flood Control and Water Conservation District, 1960, Salinas Valley geologic investigation: $11 \mathrm{p}$.

, 1971, Ground water quality in Monterey County: 52 p., 7 plates.

, 1981, Summary of water resources data, Monterey County, 1978-81: $119 \mathrm{p}$.

, 1990, Computer data sheets of water quality analyses, 180-foot aquifer, date of last update July 30, 1990, 10 p.

Schwartz, D.L., Mullins, H.T., and Belknap, D.F., 1986, Holocene geologic history of a transform margin estuary, Elkhorn STough, Central California: Estuarine, Coastal and Shelf Sciences, v. 22, p. 285-302.

Snow, Gerald, Mills, Theodore, Zidar, Matthew, and Priestaf, Iris, 1990, Identification of sources of saline intrusion in a confined aquifer system, Salinas Valley, California, in Ground water 
management: Proceedings of the 1990 Cluster of Conferences, no. 1, p. 595-607.

Tinsley, J.C. III, 1975, Quaternary geology of northern Salinas Valley, Monterey County, California [Ph.D. thesis]: Stanford University, Stanford, California, $193 \mathrm{p}$.

Todd Consulting Engineers, Inc., 1989, Sources of saline intrusion in the 400-foot aquifer, Castroville area, California: unpublished report prepared for Monterey County Flood Control and Water Conservation District, $43 \mathrm{p}$.

U.S. Environmental Protection Agency, 1977, Final environmental impact statement and environmental impact report: North Monterey County Facilities Plan, $563 \mathrm{p}$.

Vai1, P.R., Todd, R.G., and Sangree, J.B., 1977, Seismic stratigraphy and global changes of sea level-chronostratigraphic sianificance of seismic reflections, in C.E. Payton, Editor, Seismic stratigraphy applications to hydrocarbon exploration: American Association of Petroleum Geologists Memoir 26, p. 99-116.

Woodward-Clyde Consultants, 1986, Draft report on the initial investigation of Quaternary stratigraphy and contaminant flowpaths in the Firestone-Salinas area: unpublished report prepared for the Firestone Tire and Rubber Company, 22 p., 15 figures. 
APPENDIX 1

WATER QUALITY ANALYSES DATA - "180-FOOT" PRESSURE AQUIFER - RAW DATA

Obtained from Monterey County Water Resources Agency; date of report $07 / 30 / 90$; units in $\mathrm{mg} / 1$

Data are for 36 wells with complete major cation (calcium, magnesium, sodium, and potassium) and anion (bicarbonate, sulphate, chloride, and nitrate) analyses.

\begin{tabular}{|c|c|c|c|c|c|c|c|c|c|}
\hline LOCATION & DATE & $C A$ & $M G$ & $N A$ & K & $\mathrm{HCO3}$ & SO4 & $\mathrm{CL}$ & N03 \\
\hline BLANCO DRAIN & $11-\mathrm{Jan}-65$ & 130 & 197 & 551 & 5.5 & $\begin{array}{l}--- \\
690\end{array}$ & 1180 & 438 & 119.0 \\
\hline $\begin{array}{l}14213 p 1 \\
14213 p 1\end{array}$ & $\begin{array}{l}30-J u 1-54 \\
12-A u g-69\end{array}$ & $\begin{array}{l}58 \\
86\end{array}$ & $\begin{array}{l}16 \\
48\end{array}$ & $\begin{array}{l}51 \\
80\end{array}$ & $\begin{array}{l}3.8 \\
4.3\end{array}$ & $\begin{array}{l}188 \\
280\end{array}$ & $\begin{array}{l}111 \\
141\end{array}$ & $\begin{array}{r}40 \\
158\end{array}$ & $\begin{array}{r}0.0 \\
10.0\end{array}$ \\
\hline $14214 j 1$ & 18-Ju1-78 & 121 & 63 & 90 & 4.6 & 220 & 262 & 176 & 32.0 \\
\hline $14215 \mathrm{cl}$ & 14-Jun-77 & 156 & 295 & 125 & 8.2 & 142 & 186 & 1110 & 2.4 \\
\hline $\begin{array}{l}1421511 \\
1421511 \\
1421511 \\
1421511 \\
1421511 \\
1421511 \\
1421511\end{array}$ & $\begin{array}{l}04-A u g-55 \\
02-J u 7-57 \\
23-J u n-58 \\
18-J u n-59 \\
20-J u n-60 \\
12-J u 7-61 \\
18-J u 1-62\end{array}$ & $\begin{array}{l}64 \\
62 \\
62 \\
61 \\
42 \\
41 \\
44\end{array}$ & $\begin{array}{l}19 \\
19 \\
18 \\
20 \\
20 \\
28 \\
18\end{array}$ & $\begin{array}{l}53 \\
57 \\
60 \\
51 \\
53 \\
59 \\
53\end{array}$ & $\begin{array}{l}3.4 \\
3.8 \\
3.5 \\
3.6 \\
3.3 \\
2.8 \\
3.0\end{array}$ & $\begin{array}{l}216 \\
201 \\
215 \\
218 \\
160 \\
208 \\
148\end{array}$ & $\begin{array}{l}100 \\
104 \\
103 \\
105 \\
102 \\
102 \\
102\end{array}$ & $\begin{array}{l}52 \\
52 \\
58 \\
47 \\
48 \\
48 \\
43\end{array}$ & $\begin{array}{l}0.0 \\
0.0 \\
0.0 \\
0.6 \\
0.8 \\
0.5 \\
0.4\end{array}$ \\
\hline $14222 p 2$ & 10-Aug-72 & 41 & 14 & 49 & 3.0 & 158 & 76 & 38 & 0.0 \\
\hline $14223 a 1$ & 13-Aug- 73 & 82 & 30 & 74 & 3.1 & 293 & 66 & 122 & 1.2 \\
\hline $\begin{array}{l}14223 j 1 \\
14223 j 1 \\
14223 j 1 \\
14223 j 1 \\
14223 j 1 \\
14223 j 1 \\
14223 j 1 \\
14223 j 1 \\
14223 j 1 \\
14223 j 1 \\
14223 j 1\end{array}$ & $\begin{array}{l}16-\text { Aug-55 } \\
03-J u 1-57 \\
03-J u 1-58 \\
23-J u n-59 \\
22-J u n-60 \\
13-J u 1-61 \\
07-A u g-62 \\
07-A u g-64 \\
28-J u 1-65 \\
22-J u 1-66 \\
20 \text {-Aug- } 73\end{array}$ & $\begin{array}{l}83 \\
72 \\
51 \\
56 \\
89 \\
58 \\
52 \\
60 \\
74 \\
79 \\
83\end{array}$ & $\begin{array}{l}24 \\
24 \\
27 \\
26 \\
27 \\
28 \\
27 \\
30 \\
25 \\
31 \\
47\end{array}$ & $\begin{array}{l}68 \\
66 \\
66 \\
65 \\
68 \\
72 \\
71 \\
77 \\
75 \\
76 \\
91\end{array}$ & $\begin{array}{l}4.5 \\
4.7 \\
3.9 \\
4.4 \\
4.3 \\
4.3 \\
4.2 \\
5.0 \\
5.1 \\
4.4 \\
4.6\end{array}$ & $\begin{array}{l}236 \\
209 \\
154 \\
170 \\
254 \\
160 \\
132 \\
165 \\
174 \\
210 \\
218\end{array}$ & $\begin{array}{l}129 \\
127 \\
130 \\
128 \\
129 \\
133 \\
138 \\
143 \\
138 \\
146 \\
181\end{array}$ & $\begin{array}{r}86 \\
89 \\
88 \\
75 \\
96 \\
98 \\
99 \\
105 \\
108 \\
112 \\
158\end{array}$ & $\begin{array}{l}1.5 \\
2.4 \\
4.0 \\
4.0 \\
3.5 \\
3.3 \\
4.0 \\
6.7 \\
7.9 \\
4.3 \\
1.0\end{array}$ \\
\hline $14224 j 1$ & 14-Jun-77 & 77 & 52 & 205 & 7.0 & 249 & 264 & 163 & 174.0 \\
\hline
\end{tabular}




\begin{tabular}{|c|c|c|c|c|c|c|c|c|c|}
\hline LOCATION & DATE & $C A$ & $M G$ & NA & K & $\mathrm{HCO}$ & S04 & $\mathrm{CL}$ & N03 \\
\hline $\begin{array}{l}14225 \mathrm{bl} \\
14225 \mathrm{bl} \\
14225 \mathrm{~b} 1\end{array}$ & $\begin{array}{l}29-J u 1-55 \\
03-J u 1-57 \\
12-J u 1-62\end{array}$ & $\begin{array}{r}105 \\
82 \\
110\end{array}$ & $\begin{array}{l}39 \\
41 \\
39\end{array}$ & $\begin{array}{l}92 \\
88 \\
94\end{array}$ & $\begin{array}{l}--- \\
4.3 \\
4.4 \\
3.8\end{array}$ & $\begin{array}{l}337 \\
277 \\
302\end{array}$ & $\begin{array}{l}110 \\
119 \\
156\end{array}$ & $\begin{array}{l}--- \\
145 \\
151 \\
162\end{array}$ & $\begin{array}{r}11.0 \\
13.0 \\
5.3\end{array}$ \\
\hline $14225 \mathrm{~d} 1$ & 09-Aug-72 & 97 & 38 & 139 & 6.4 & 275 & 187 & 186 & 29.0 \\
\hline $14225 f 1$ & 09-Aug-72 & 124 & 38 & 167 & 5.4 & 293 & 238 & 228 & 13.0 \\
\hline $\begin{array}{l}14226 \mathrm{al} \\
14226 \mathrm{a} 1 \\
14226 \mathrm{al} \\
14226 \mathrm{a} 1 \\
14226 \mathrm{al} \\
14226 \mathrm{al} \\
14226 \mathrm{al}\end{array}$ & $\begin{array}{l}18 \text {-Aug-55 } \\
03-J u 1-57 \\
20-J u n-58 \\
23-J u n-59 \\
22-\text { Jun }-60 \\
13-J u 1-61 \\
18-J u 1-62\end{array}$ & $\begin{array}{r}101 \\
77 \\
76 \\
98 \\
69 \\
107 \\
102\end{array}$ & $\begin{array}{l}34 \\
33 \\
36 \\
41 \\
38 \\
43 \\
43\end{array}$ & $\begin{array}{l}76 \\
76 \\
82 \\
76 \\
82 \\
88 \\
98\end{array}$ & $\begin{array}{l}4.3 \\
4.6 \\
4.2 \\
4.6 \\
4.0 \\
4.4 \\
4.6\end{array}$ & $\begin{array}{l}264 \\
175 \\
156 \\
244 \\
127 \\
224 \\
195\end{array}$ & $\begin{array}{l}157 \\
142 \\
172 \\
171 \\
174 \\
192 \\
194\end{array}$ & $\begin{array}{l}129 \\
134 \\
150 \\
199 \\
162 \\
180 \\
195\end{array}$ & $\begin{array}{l}1.6 \\
2.3 \\
3.0 \\
2.1 \\
2.5 \\
2.8 \\
0.0\end{array}$ \\
\hline $14236 \mathrm{el}$ & 29-Aug-73 & 210 & 80 & 85 & 6.3 & 352 & 432 & 201 & 0.0 \\
\hline $14319 q 2$ & 21 -Aug - 73 & 90 & 43 & 88 & 3.2 & 352 & 48 & 174 & 14.0 \\
\hline 1432914 & 20-Aug-79 & 120 & 56 & 120 & 2.0 & 492 & 119 & 194 & 23.0 \\
\hline $14330 \mathrm{bl}$ & $03-J u 1-57$ & 57 & 24 & 55 & 3.3 & 214 & 31 & 100 & 2.1 \\
\hline $\begin{array}{l}14330 \mathrm{el} \\
14330 \mathrm{e} 1 \\
14330 \mathrm{e} 1 \\
14330 \mathrm{el} \\
14330 \mathrm{e} 1 \\
14330 \mathrm{el}\end{array}$ & $\begin{array}{l}29-J u 1-55 \\
03-J u 1-57 \\
12-J u T-62 \\
22-\text { Aug }-63 \\
07-J u 1-75 \\
14-J u n-77\end{array}$ & $\begin{array}{r}139 \\
66 \\
323 \\
120 \\
113 \\
138\end{array}$ & $\begin{array}{l}55 \\
51 \\
44 \\
76 \\
81 \\
77\end{array}$ & $\begin{array}{l}135 \\
133 \\
157 \\
167 \\
194 \\
202\end{array}$ & $\begin{array}{l}6.0 \\
5.6 \\
4.3 \\
5.3 \\
6.3 \\
7.4\end{array}$ & $\begin{array}{l}431 \\
211 \\
464 \\
307 \\
248 \\
312\end{array}$ & $\begin{array}{l}168 \\
157 \\
233 \\
235 \\
344 \\
353\end{array}$ & $\begin{array}{l}247 \\
234 \\
312 \\
326 \\
328 \\
315\end{array}$ & $\begin{array}{r}8.8 \\
8.7 \\
8.5 \\
10.0 \\
38.0 \\
38.0\end{array}$ \\
\hline $\begin{array}{l}14330 \mathrm{fl} \\
14330 \mathrm{fl} \\
14330 \mathrm{fl} \\
14330 \mathrm{fl} \\
14330 \mathrm{fl} \\
14330 \mathrm{fl} \\
14330 \mathrm{fl}\end{array}$ & $\begin{array}{l}29-J u 1-55 \\
03-J u 1-57 \\
16-J u n-59 \\
23-J u n-60 \\
13-J u 1-61 \\
12-J u 1-62 \\
17-J u n-77\end{array}$ & $\begin{array}{r}119 \\
73 \\
48 \\
42 \\
75 \\
78 \\
82\end{array}$ & $\begin{array}{l}45 \\
48 \\
50 \\
52 \\
49 \\
55 \\
58\end{array}$ & $\begin{array}{l}128 \\
127 \\
131 \\
133 \\
139 \\
157 \\
199\end{array}$ & $\begin{array}{l}4.6 \\
5.0 \\
4.9 \\
4.4 \\
2.0 \\
3.8 \\
7.1\end{array}$ & $\begin{array}{l}462 \\
342 \\
227 \\
185 \\
266 \\
261 \\
251\end{array}$ & $\begin{array}{r}78 \\
81 \\
95 \\
113 \\
109 \\
152 \\
272\end{array}$ & $\begin{array}{l}203 \\
216 \\
220 \\
232 \\
249 \\
257 \\
241\end{array}$ & $\begin{array}{r}12.0 \\
12.0 \\
14.0 \\
18.0 \\
0.0 \\
22.0 \\
53.0\end{array}$ \\
\hline $14330 n 1$ & 20-Jun-77 & 98 & 63 & 223 & 7.9 & 281 & 396 & 200 & 56.0 \\
\hline $14331 \mathrm{fl}$ & $06-$ Aug- 69 & 165 & 91 & 193 & 8.3 & 204 & 553 & 336 & 14.0 \\
\hline
\end{tabular}




\begin{tabular}{|c|c|c|c|c|c|c|c|c|c|}
\hline LOCATION & DATE & CA & $M G$ & NA & $K$ & $\mathrm{HCO}$ & SO4 & $\mathrm{CL}$ & NO3 \\
\hline $\begin{array}{l}14333 \mathrm{gl} \\
14333 \mathrm{gl} \\
14333 \mathrm{gl} \\
14333 \mathrm{gl} \\
14333 \mathrm{gl} \\
14333 \mathrm{gl} \\
14333 \mathrm{gl} \\
14333 \mathrm{gl} \\
14333 \mathrm{gl} \\
14333 \mathrm{gl}\end{array}$ & $\begin{array}{l}\text { 12-Aug-55 } \\
01-J u 1-58 \\
16-J u n-59 \\
28-J u n-60 \\
13-J u 1-61 \\
20-J u 1-62 \\
19-\text { Aug }-63 \\
26-\text { Aug }-64 \\
24-\text { Aug }-65 \\
25-J u 1-74\end{array}$ & $\begin{array}{l}44 \\
48 \\
50 \\
56 \\
50 \\
50 \\
50 \\
72 \\
68 \\
77\end{array}$ & $\begin{array}{r}20 \\
22 \\
24 \\
24 \\
29 \\
21 \\
25 \\
6 \\
22 \\
32\end{array}$ & $\begin{array}{l}47 \\
52 \\
52 \\
53 \\
55 \\
53 \\
58 \\
46 \\
63 \\
63\end{array}$ & $\begin{array}{l}2.7 \\
2.4 \\
3.0 \\
2.7 \\
2.6 \\
2.7 \\
2.8 \\
2.6 \\
3.3 \\
3.3\end{array}$ & $\begin{array}{l}152 \\
173 \\
190 \\
193 \\
200 \\
174 \\
197 \\
164 \\
172 \\
237\end{array}$ & $\begin{array}{l}30 \\
44 \\
45 \\
49 \\
53 \\
58 \\
73 \\
19 \\
85 \\
92\end{array}$ & $\begin{array}{r}83 \\
96 \\
95 \\
98 \\
102 \\
78 \\
74 \\
91 \\
94 \\
121\end{array}$ & $\begin{array}{r}2.4 \\
1.0 \\
3.2 \\
3.3 \\
2.3 \\
3.6 \\
4.3 \\
17.0 \\
7.3 \\
14.0\end{array}$ \\
\hline $\begin{array}{l}1521 \mathrm{al} \\
1521 \mathrm{al}\end{array}$ & $\begin{array}{l}03-J u 1-57 \\
20-J u n-58\end{array}$ & $\begin{array}{l}132 \\
133\end{array}$ & $\begin{array}{l}70 \\
69\end{array}$ & $\begin{array}{l}119 \\
129\end{array}$ & $\begin{array}{l}6.9 \\
6.1\end{array}$ & $\begin{array}{l}166 \\
161\end{array}$ & $\begin{array}{l}449 \\
485\end{array}$ & $\begin{array}{l}185 \\
189\end{array}$ & $\begin{array}{l}1.7 \\
0.0\end{array}$ \\
\hline $1521 \mathrm{k} 1$ & 15-Aug-79 & 149 & 53 & 83 & 3.9 & 299 & 308 & 150 & 0.9 \\
\hline $\begin{array}{l}1522 j 1 \\
1522 j 1\end{array}$ & $\begin{array}{l}\text { 14-Jun-77 } \\
15 \text {-Aug-79 }\end{array}$ & $\begin{array}{r}94 \\
131\end{array}$ & $\begin{array}{l}44 \\
54\end{array}$ & $\begin{array}{l}122 \\
127\end{array}$ & $\begin{array}{l}7.5 \\
7.8\end{array}$ & $\begin{array}{l}270 \\
346\end{array}$ & $\begin{array}{l}352 \\
374\end{array}$ & $\begin{array}{l}104 \\
110\end{array}$ & $\begin{array}{l}0.0 \\
1.7\end{array}$ \\
\hline $\begin{array}{l}1522 q 1 \\
1522 q 1 \\
1522 q 1 \\
1522 q 1 \\
1522 q 1 \\
1522 q 1 \\
1522 q 1 \\
1522 q 1\end{array}$ & $\begin{array}{l}26-J u 1-55 \\
03-J u 1-57 \\
30-J u n-58 \\
23-J u n-59 \\
20-J u n-60 \\
09-J u 1-62 \\
01-J u n-63 \\
10 \text {-Aug-72 }\end{array}$ & $\begin{array}{r}120 \\
62 \\
52 \\
75 \\
90 \\
86 \\
62 \\
111\end{array}$ & $\begin{array}{l}42 \\
45 \\
46 \\
54 \\
51 \\
49 \\
57 \\
46\end{array}$ & $\begin{array}{l}58 \\
60 \\
65 \\
62 \\
60 \\
74 \\
75 \\
88\end{array}$ & $\begin{array}{l}3.8 \\
4.2 \\
3.9 \\
4.4 \\
5.0 \\
3.3 \\
4.1 \\
4.6\end{array}$ & $\begin{array}{l}391 \\
220 \\
169 \\
279 \\
298 \\
307 \\
257 \\
293\end{array}$ & $\begin{array}{l}186 \\
167 \\
207 \\
207 \\
200 \\
208 \\
217 \\
252\end{array}$ & $\begin{array}{r}64 \\
74 \\
79 \\
77 \\
86 \\
74 \\
76 \\
104\end{array}$ & $\begin{array}{l}0.0 \\
0.0 \\
0.0 \\
0.0 \\
0.7 \\
0.0 \\
0.5 \\
0.0\end{array}$ \\
\hline $15212 \mathrm{cl}$ & 09-Aug-72 & 93 & 40 & 54 & 3.7 & 234 & 168 & 87 & 0.0 \\
\hline $\begin{array}{l}153411 \\
153411 \\
153411 \\
153411\end{array}$ & $\begin{array}{l}26-J u 1-55 \\
05-J u 1-57 \\
23-J u n-58 \\
23-J u n-59\end{array}$ & $\begin{array}{r}163 \\
93 \\
102 \\
68\end{array}$ & $\begin{array}{l}58 \\
61 \\
62 \\
72\end{array}$ & $\begin{array}{l}140 \\
136 \\
145 \\
150\end{array}$ & $\begin{array}{l}5.8 \\
6.4 \\
4.2 \\
5.9\end{array}$ & $\begin{array}{l}490 \\
266 \\
316 \\
176\end{array}$ & $\begin{array}{l}266 \\
354 \\
294 \\
311\end{array}$ & $\begin{array}{l}168 \\
130 \\
181 \\
188\end{array}$ & $\begin{array}{l}22.0 \\
17.0 \\
13.0 \\
52.0\end{array}$ \\
\hline $\begin{array}{l}1535 q 4 \\
1535 q 4 \\
1535 q 4 \\
1535 q 4 \\
1535 q 4 \\
1535 q 4 \\
1535 q 4\end{array}$ & $\begin{array}{l}15-J u 1-55 \\
03-J u 1-57 \\
22-J u n-59 \\
29-J u n-60 \\
14-J u 1-61 \\
07-\text { Aug- } 62 \\
25-J u 1-75\end{array}$ & $\begin{array}{r}137 \\
138 \\
197 \\
88 \\
97 \\
107 \\
139\end{array}$ & $\begin{array}{l}73 \\
72 \\
82 \\
81 \\
76 \\
71 \\
81\end{array}$ & $\begin{array}{l}217 \\
233 \\
234 \\
244 \\
238 \\
255 \\
250\end{array}$ & $\begin{array}{l}7.4 \\
8.0 \\
7.4 \\
6.7 \\
5.6 \\
6.5 \\
7.7\end{array}$ & $\begin{array}{l}328 \\
298 \\
498 \\
198 \\
180 \\
157 \\
215\end{array}$ & $\begin{array}{l}487 \\
542 \\
566 \\
565 \\
580 \\
624 \\
746\end{array}$ & $\begin{array}{l}241 \\
238 \\
231 \\
235 \\
238 \\
243 \\
215\end{array}$ & $\begin{array}{l}1.2 \\
1.2 \\
1.1 \\
1.0 \\
1.9 \\
0.0 \\
0.6\end{array}$ \\
\hline 15361 & $28-J u 1-55$ & 201 & 77 & 109 & 6.0 & 336 & 530 & 165 & 1.2 \\
\hline
\end{tabular}




\begin{tabular}{|c|c|c|c|c|c|c|c|c|c|}
\hline $\begin{array}{l}\text { LOCATION } \\
1537 \mathrm{~d} 1 \\
1537 \mathrm{~d} 1 \\
1537 \mathrm{dl} \\
1537 \mathrm{dl} \\
1537 \mathrm{dl} \\
1537 \mathrm{dl} \\
1537 \mathrm{dl} \\
1537 \mathrm{dl}\end{array}$ & $\begin{array}{c}\text { DATE } \\
-26-J u T-55 \\
30-J u 1-57 \\
20-J u n-58 \\
24-J u n-59 \\
20-J u n-60 \\
14-J u 1-61 \\
20-J u 7-62 \\
13-\text { Aug-63 }\end{array}$ & $\begin{array}{r}\text { CA } \\
--- \\
148 \\
136 \\
80 \\
71 \\
73 \\
85 \\
87 \\
92\end{array}$ & $\begin{array}{l}M G \\
- \\
54 \\
51 \\
55 \\
51 \\
52 \\
56 \\
56 \\
72\end{array}$ & $\begin{array}{l}\text { NA } \\
-\cdots \\
80 \\
77 \\
77 \\
71 \\
77 \\
82 \\
77 \\
82\end{array}$ & $\begin{array}{l}K \\
-\cdots \\
4.7 \\
4.9 \\
4.2 \\
4.4 \\
4.2 \\
4.3 \\
4.3 \\
4.7\end{array}$ & \begin{tabular}{r}
$\mathrm{HCO3}$ \\
\hdashline 329 \\
318 \\
138 \\
149 \\
141 \\
156 \\
143 \\
246
\end{tabular} & $\begin{array}{l}\text { S04 } \\
-\cdots \\
300 \\
288 \\
301 \\
257 \\
276 \\
318 \\
302 \\
314\end{array}$ & $\begin{array}{l}\mathrm{CL} \\
-- \\
118 \\
116 \\
126 \\
100 \\
118 \\
125 \\
130 \\
130\end{array}$ & \begin{tabular}{l} 
N03 \\
\hdashline 0.0 \\
0.4 \\
0.0 \\
0.8 \\
0.0 \\
0.0 \\
0.0 \\
0.0
\end{tabular} \\
\hline $537 n 1$ & 15-Aug-79 & 154 & 56 & 74 & 3.9 & 303 & 351 & 112 & 0.9 \\
\hline $\begin{array}{l}1538 \mathrm{bl} \\
1538 \mathrm{n} 1 \\
1538 \mathrm{n} 1 \\
1538 \mathrm{n} 1 \\
1538 \mathrm{n} 1\end{array}$ & $\begin{array}{l}20-J u n-77 \\
26-J u 7-55 \\
03-J u T-57 \\
19-J u n-59 \\
28-J u n-60\end{array}$ & $\begin{array}{r}112 \\
119 \\
64 \\
46 \\
54\end{array}$ & $\begin{array}{l}73 \\
44 \\
39 \\
79 \\
46\end{array}$ & $\begin{array}{r}217 \\
77 \\
69 \\
65 \\
74\end{array}$ & $\begin{array}{l}7.2 \\
4.8 \\
4.5 \\
4.4 \\
3.9\end{array}$ & $\begin{array}{l}351 \\
349 \\
210 \\
355 \\
189\end{array}$ & $\begin{array}{l}566 \\
248 \\
221 \\
213 \\
228\end{array}$ & $\begin{array}{r}116 \\
70 \\
60 \\
57 \\
64\end{array}$ & $\begin{array}{r}13.0 \\
0.0 \\
0.0 \\
0.0 \\
0.0\end{array}$ \\
\hline $539 b$ & 15-Aug-79 & 118 & 58 & 156 & 7.8 & 427 & 390 & 94 & 1.3 \\
\hline 39 & 5-Jun-77 & 84 & 54 & .77 & 6.4 & 281 & 408 & 11 & .3 \\
\hline
\end{tabular}




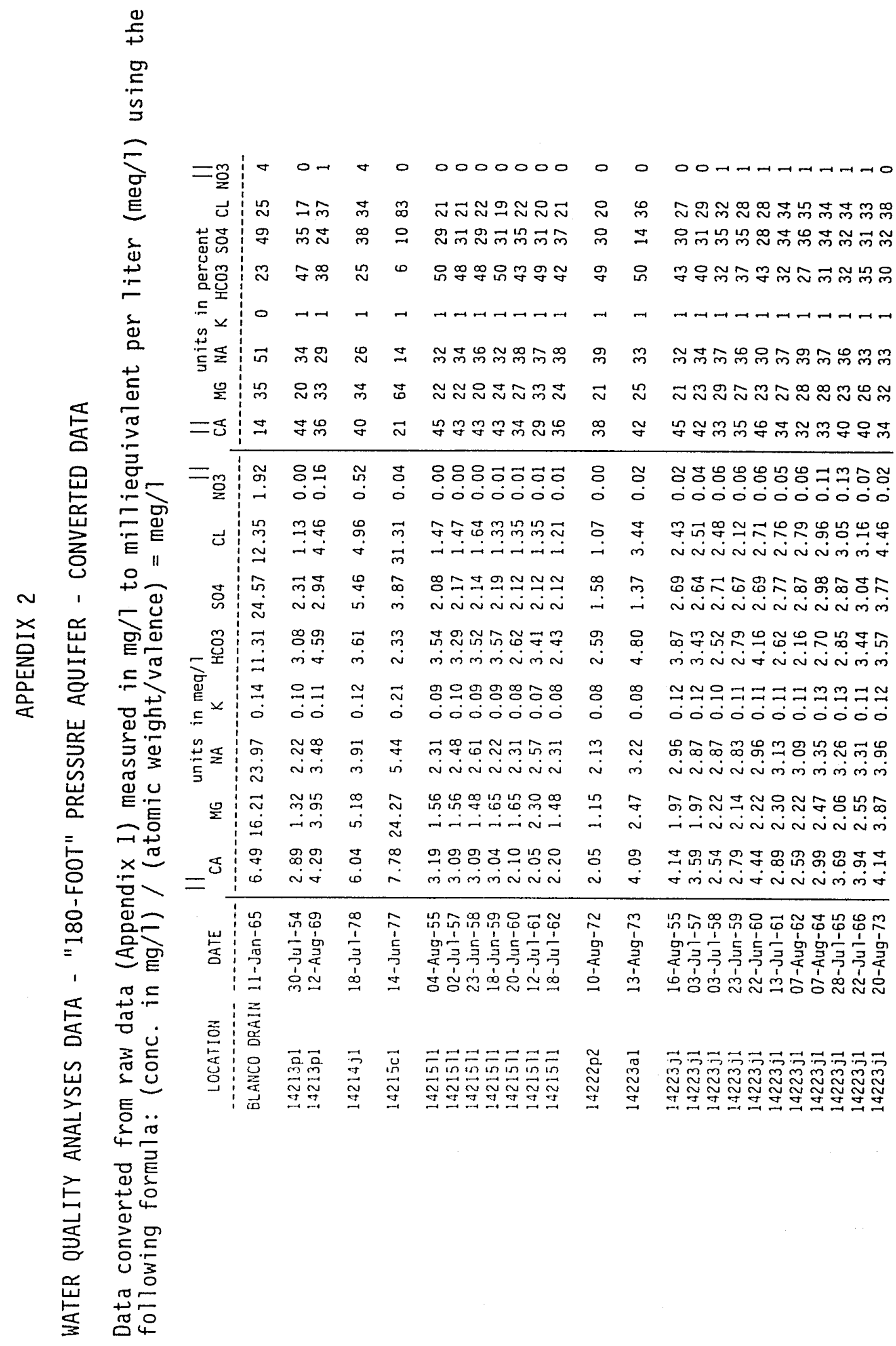




\begin{tabular}{|c|c|c|c|c|c|c|c|c|c|c|c|}
\hline & $\cong$ & $r \sim m$ & $m$ & -7 & 0000000 & 0 & $\sim$ & $\sim$ & $\circ$ & $\neg \rightarrow \neg \rightarrow \mathrm{mm}$ & $H \rightarrow \sim N O N$ L \\
\hline & $\approx$ & 芦闬品 & $\hat{m}$ & g & 浮 & $\stackrel{\infty}{\sim}$ & $\vec{\sigma}$ & $m$ & q & 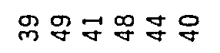 & 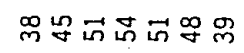 \\
\hline & $\tilde{m}$ & $9 \approx \sim ⿻ 上$ & $\stackrel{\infty}{\infty}$ & 요 & 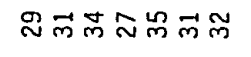 & $\vec{\forall}$ & $\infty$ & $\stackrel{n}{-}$ & $\sigma$ & 只忍出正 & 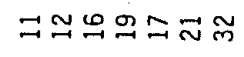 \\
\hline & 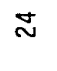 & 웅ㅇㅇ용 & $\approx$ & : & జ్ల ర్లి జ & $\stackrel{\infty}{\sim}$ & $\stackrel{\infty}{\sim}$ & $g$ & 용 & 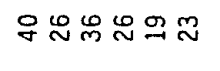 & 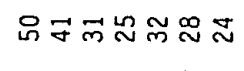 \\
\hline & - & 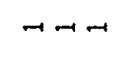 & $\rightarrow$ & - & 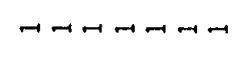 & $\rightarrow$ & -1 & 0 & $\rightarrow$ & $\rightarrow-0-7-1$ & 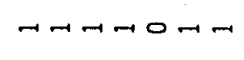 \\
\hline & ก & ఇ్లా & F & 9 & 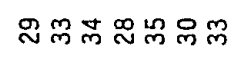 & $\stackrel{\infty}{\rightarrow}$ & $\tilde{m}$ & $\stackrel{m}{m}$ & $m$ & 芦甼怘的昌 & 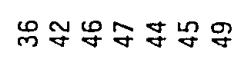 \\
\hline & $\stackrel{\sim}{\sim}$ & 임요 & $\approx$ & 9 & $\stackrel{2}{\sim} \stackrel{\infty}{\sim} \bar{m} \stackrel{\infty}{\sim} \approx$ & $\vec{m}$ & 요 & $\mathscr{D}$ & $\approx$ & $\mathscr{N} \vec{m} \sqsupset \tilde{m} \check{్} \check{N}$ & న \\
\hline & $\approx$ & $\approx \mathscr{*} \mathscr{m}$ & 声 & $\hat{m}$ & 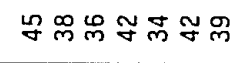 & in & 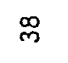 & 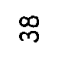 & g & 움요욤요 & 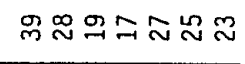 \\
\hline & $\stackrel{\vec{\infty}}{\sim}$ & 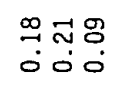 & fa & $\stackrel{\tilde{a}}{0}$ & 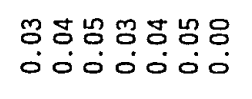 & $\begin{array}{l}8 \\
:\end{array}$ & $\stackrel{\Re}{\dddot{0}}$ & $\begin{array}{l}\hat{m} \\
0 \\
0\end{array}$ & $\begin{array}{l}m \\
0 \\
0\end{array}$ & 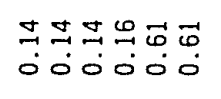 & 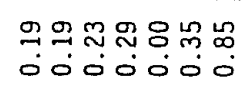 \\
\hline & 8. & 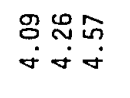 & $\begin{array}{l}\stackrel{n}{\sim} \\
\text { in }\end{array}$ & $\underset{m}{\mathfrak{m}}$ & 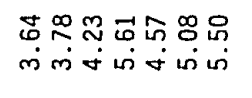 & $\begin{array}{l}\hat{\omega} \\
i \\
i\end{array}$ & $\vec{\sigma}$ & $\hat{f}$ & $\stackrel{\sim}{\sim}$ & & \\
\hline & $\begin{array}{l}\text { in } \\
\text { in }\end{array}$ & 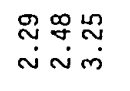 & $\begin{array}{c}\infty \\
\infty \\
m\end{array}$ & $\stackrel{\mathscr{q}}{\dot{q}}$ & 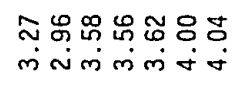 & 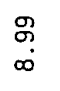 & $\stackrel{8}{\circ}$ & $\stackrel{\infty}{\stackrel{\infty}{\sim}}$ & $\begin{array}{l}\stackrel{0}{0} \\
\stackrel{0}{0}\end{array}$ & & \\
\hline & $\stackrel{\infty}{\circ}$ & 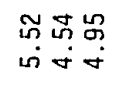 & $\overrightarrow{\vec{n}}$ & $\begin{array}{l}\stackrel{\infty}{\infty} \\
\dot{\sigma}\end{array}$ & 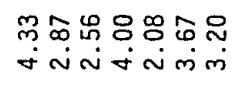 & in & $\stackrel{i}{i}$ & $\begin{array}{l}\mathscr{0} \\
\infty \\
\infty\end{array}$ & $\begin{array}{l}\vec{n} \\
\dot{m}\end{array}$ & & 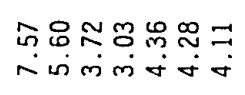 \\
\hline & $\stackrel{\infty}{-1}$ & $\begin{array}{l}\exists=0 \\
\exists=0 \\
000\end{array}$ & $\stackrel{0}{\dddot{0}}$ & $\underset{⿱ 亠 䒑}{ \pm}$ & 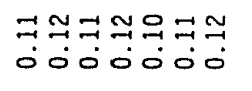 & $\stackrel{0}{?}$ & $\begin{array}{l}\infty \\
0 \\
\dot{0}\end{array}$ & $\begin{array}{l}\text { L } \\
\dot{0}\end{array}$ & $\begin{array}{l}\infty \\
\stackrel{0}{0}\end{array}$ & 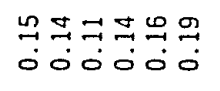 & 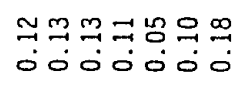 \\
\hline & $\tilde{\sigma}$ & 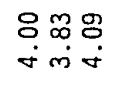 & $\begin{array}{l}\text { ro } \\
0 \\
6\end{array}$ & $\stackrel{\stackrel{\leftrightarrow}{\leftrightarrow}}{\sim}$ & 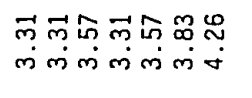 & $\stackrel{P}{\stackrel{9}{m}}$ & $\begin{array}{l}\stackrel{m}{\infty} \\
m \\
m\end{array}$ & $\underset{\sim}{\sim}$ & 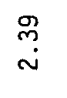 & 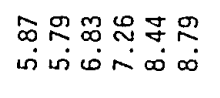 & 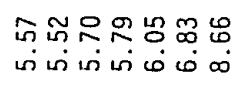 \\
\hline & $\stackrel{\infty}{\sim}$ & $\begin{array}{l}\vec{N} \hat{m} \vec{N} \\
\dot{m} \tilde{m}\end{array}$ & $\underset{m}{m}$ & $\stackrel{m}{m}$ & 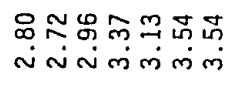 & $\begin{array}{l}\infty \\
\stackrel{\infty}{?} \\
\bullet\end{array}$ & 离 & $\vec{\varphi}$ & $\stackrel{\hat{o}}{\stackrel{-}{-}}$ & 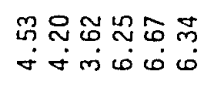 & 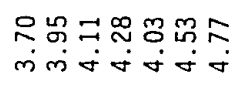 \\
\hline & $\underset{.}{\infty}$ & 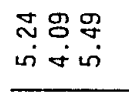 & $\begin{array}{l}\vec{D} \\
\dot{\sigma}\end{array}$ & $\underset{9}{\stackrel{9}{0}}$ & 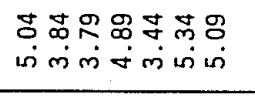 & 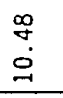 & $\underset{g}{\dot{g}}$ & $\begin{array}{l}\text { gr } \\
\text { in }\end{array}$ & $\underset{\substack{\infty \\
\sim}}{\sim}$ & 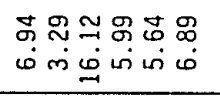 & 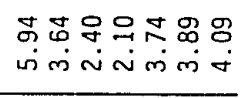 \\
\hline 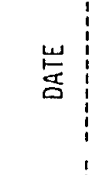 & î & 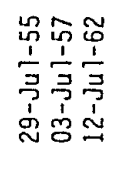 & $\begin{array}{l}\approx \\
\hat{1} \\
9 \\
\vdots \\
1 \\
0 \\
0\end{array}$ & 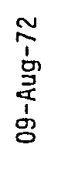 & 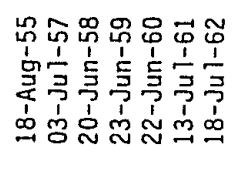 & 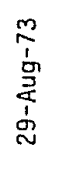 & $\begin{array}{l}m \\
0 \\
\vdots \\
a \\
\vdots \\
\vdots \\
N\end{array}$ & 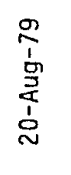 & $\begin{array}{l}\frac{5}{1} \\
\frac{1}{3} \\
\frac{1}{3} \\
0\end{array}$ & 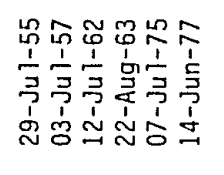 & 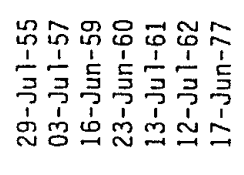 \\
\hline 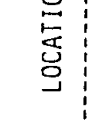 & $\underset{\sim}{\mathbb{S}}$ & 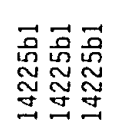 & 芯 & 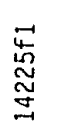 & 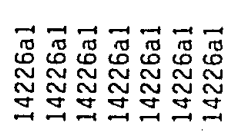 & $\begin{array}{l}\bar{\Xi} \\
\stackrel{心}{\mathbb{N}} \\
\stackrel{\Xi}{ }\end{array}$ & 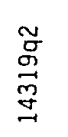 & 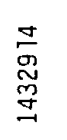 & $\begin{array}{l}\vec{\Delta} \\
\text { 总 } \\
\text { 吾 }\end{array}$ & 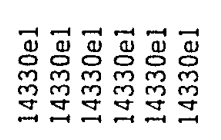 & 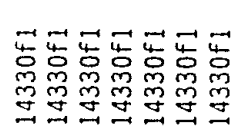 \\
\hline
\end{tabular}




\begin{tabular}{|c|c|c|c|c|c|c|c|c|c|}
\hline$=g$ & n & - & 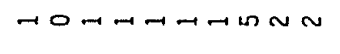 & 00 & 0 & 00 & 00000000 & 0 & $\sim \sim \sim m$ \\
\hline & g & g & 寽 $̛$ 于 & 윰요 & $\approx$ & 옹요 & 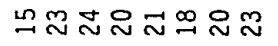 & $\stackrel{N}{N}$ & $\stackrel{\sim}{\sim} \vec{m}$ \\
\hline & F & F & 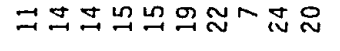 & wis & $\vec{\nabla}$ & 员F & 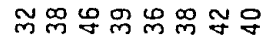 & $\mathscr{m}$ & 轲命尔 \\
\hline & $\stackrel{\sim}{N}$ & \pm & 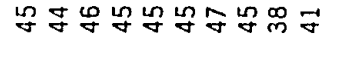 & $\mathscr{\varphi} \simeq$ & $\vec{m}$ & 品 & 꼼유 & 忿 & 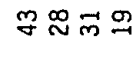 \\
\hline & $\rightarrow$ & $\rightarrow$ & ナーナナーナーナーヤ & $\neg \rightarrow$ & -1 & $\rightarrow-$ & 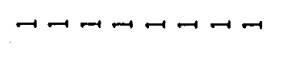 & $\rightarrow$ & ナナナナ \\
\hline & g & $\stackrel{\mathscr{m}}{m}$ & 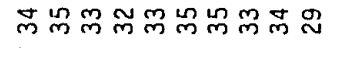 & D $\vec{m}$ & $\cong$ & $\stackrel{m}{m}$ & הミ足怘怘怘 & $\stackrel{m}{N}$ & $\tilde{m} \underset{m}{\infty} \underset{m}{\infty}$ \\
\hline & $\stackrel{\infty}{\sim}$ & $\vec{m}$ & $\stackrel{\infty}{\sim} \stackrel{\infty}{\sim} \stackrel{\infty}{\sim} \underset{m}{2} \stackrel{\sim}{\sim} \underset{\sim}{\infty} \stackrel{\infty}{\sim}$ & $m \vec{m}$ & $\stackrel{\infty}{\sim}$ & $\stackrel{\sim}{\sim}$ & 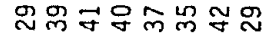 & $\tilde{m}$ & ผึ $\tilde{m} \bar{m}$ \\
\hline & 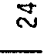 & 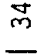 & 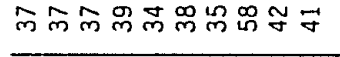 & $\hat{m} \tilde{n}$ & $\stackrel{\infty}{+}$ & 迎 & 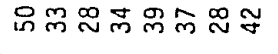 & $\stackrel{40}{\square}$ & 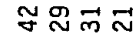 \\
\hline & 足 & $\stackrel{m}{\dddot{m}}$ & 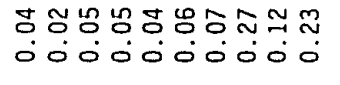 & 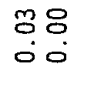 & $\begin{array}{l}\ddot{0} \\
\dot{0}\end{array}$ & $\begin{array}{l}80 \\
80 \\
00\end{array}$ & $\begin{array}{l}80 \\
00\end{array}$ & $\dot{5}$ & \\
\hline & $\begin{array}{l}\text { से } \\
\text { in }\end{array}$ & $\begin{array}{l}\infty \\
\stackrel{\infty}{\sigma} \\
\dot{\sigma}\end{array}$ & 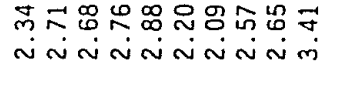 & & $\stackrel{\dddot{m}}{\ddot{\sigma}}$ & m & $\vec{\infty}$ & $\dot{j}$ & \\
\hline & $\stackrel{12}{\sim}$ & $\stackrel{\check{2}}{\leftrightarrows}$ & đ̃ a & in & $\vec{\forall}$ & $m i$ & $\infty$ & i⿱口 & \\
\hline & $\begin{array}{l}\overrightarrow{0} \\
\dot{\sigma}\end{array}$ & m & $\begin{array}{l}\text { gु } \\
\stackrel{5}{\sim} \\
\stackrel{\sim}{\sim}\end{array}$ & $\underset{\sim}{\approx}$ & $\begin{array}{l}8 \\
\dot{9}\end{array}$ & 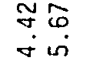 & $\begin{array}{l}F \overline{0} \\
0 \%\end{array}$ & $\dot{m}$ & \\
\hline & $\stackrel{0}{\sim}$ & $\ddot{\sim}$ & $\begin{array}{l}\text { 영ㅇㅇㅇㅇㅇㅇㅇㅇㅇㅇㅇㅇㅇ } \\
0000000000\end{array}$ & $\stackrel{\infty}{\infty} \stackrel{0}{0}$ & $\stackrel{0}{0}$ & $\stackrel{9}{?}$ & $\begin{array}{l}0 \\
\div 0\end{array}$ & $\begin{array}{l}g \\
0\end{array}$ & 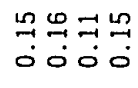 \\
\hline & $\stackrel{P}{\stackrel{P}{\sigma}}$ & $\stackrel{\circ}{+}$ & $\begin{array}{l}\stackrel{0}{0} \stackrel{\infty}{\sim} \\
\sim \sim\end{array}$ & $\stackrel{\infty}{\rightarrow}$ & $\vec{b}$ & $\begin{array}{l}\vec{m} \\
\text { si }\end{array}$ & 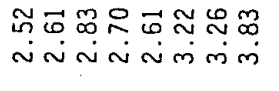 & $\stackrel{m}{m}$ & \\
\hline & $\stackrel{\infty}{\because}$ & $\stackrel{\text { P }}{i}$ & 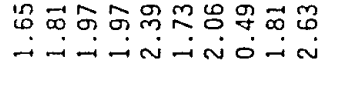 & $\stackrel{\infty}{\sim}$ & $\stackrel{\infty}{?}$ & $\underset{\tilde{\sigma}}{\tilde{m}}$ & & $\stackrel{g}{\sim}$ & \\
\hline & $\stackrel{\substack{\infty \\
\infty}}{.}$ & $\underset{m}{\sim}$ & 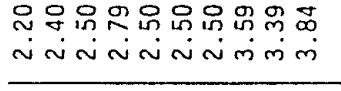 & or & $\stackrel{\text { J }}{\stackrel{5}{r}}$ & $\begin{array}{l}9.5 \\
6 \\
+4 \\
\end{array}$ & & $\begin{array}{l}\vec{G} \\
\dot{\sigma}\end{array}$ & \\
\hline 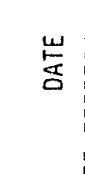 & $\stackrel{1}{5}$ & $\begin{array}{l}9 \\
0 \\
1 \\
0 \\
\vdots \\
\vdots \\
1 \\
0 \\
0\end{array}$ & 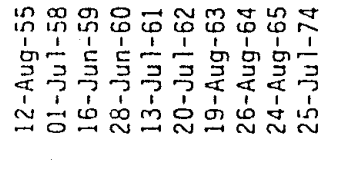 & 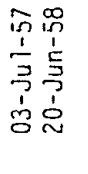 & 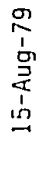 & 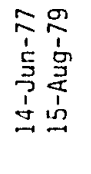 & 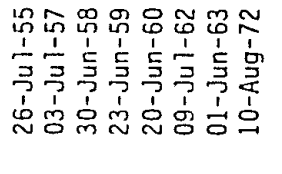 & 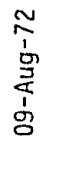 & 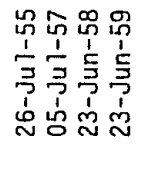 \\
\hline$\xi$ & 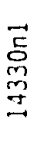 & 离 & 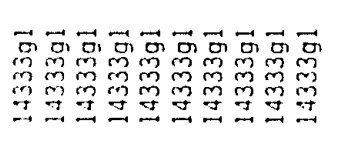 & 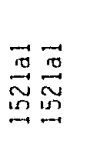 & $\underset{\underline{*}}{\stackrel{\vec{N}}{N}}$ & $\overrightarrow{\widetilde{N}}$ & 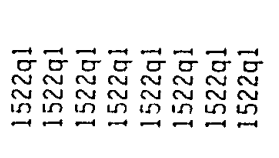 & 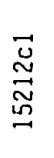 & 雍 \\
\hline
\end{tabular}




\begin{tabular}{|c|c|c|c|c|c|c|c|}
\hline-6 & 0000000 & 0 & 00000000 & 0 & $\rightarrow$ & 0000 & $\rightarrow$ \\
\hline & 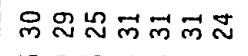 & $\approx$ & 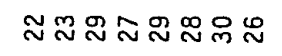 & 요 & $\stackrel{0}{\sim}$ & ณニさ9 & $\stackrel{\Omega}{\sim}$ \\
\hline & ס & $\tilde{ก}$ & $\mathcal{z}$ & $\hat{\sigma}$ & in & & $q$ \\
\hline & ざョ怘さニさ & $\stackrel{2}{\sim}$ & $\mathscr{m}$ & $\tilde{m}$ & $\hat{N}$ & 需奋 & g \\
\hline & 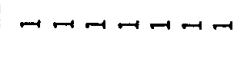 & $\rightarrow$ & 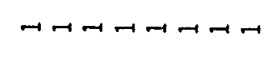 & - & $\rightarrow$ & サールー & - \\
\hline & 导 g g & $\approx$ & 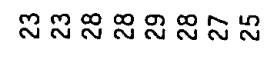 & $\vec{\sim}$ & $z$ & $\stackrel{\sim}{\sim} \approx \tilde{m}$ & $\stackrel{\infty}{m}$ \\
\hline & 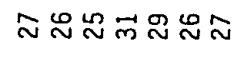 & 요 & 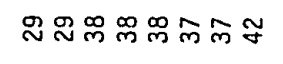 & 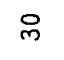 & $\stackrel{\infty}{\sim}$ & 怘正员品 & $\approx$ \\
\hline & 요요 & $\hat{7}$ & $\stackrel{\infty}{\forall} \bar{y}$ & g & $\stackrel{\sim}{N}$ & 果层㣽怘 & m \\
\hline & $\begin{array}{l}\approx \approx \\
0 \\
0 \\
0\end{array}$ & 0 & & $\overrightarrow{0}$ & $\stackrel{7}{*}$ & & $\underset{-\infty}{\infty}$ \\
\hline & $\begin{array}{l}87 \\
0 \\
0\end{array}$ & $\stackrel{2}{0}$ & & 0 & N & & \\
\hline & & $\stackrel{+}{\stackrel{\Delta}{\Xi}}$ & & $\stackrel{\vec{m}}{r}$ & $\stackrel{\infty}{=}$ & & $\underset{\infty}{\simeq}$ \\
\hline & $\begin{array}{l}\infty \\
m_{\infty}^{\infty} \\
\omega^{\infty}\end{array}$ & $\begin{array}{l}\text { in } \\
\text { in }\end{array}$ & & $\stackrel{\hat{o}}{\dot{\sigma}}$ & $\stackrel{n}{\stackrel{n}{i n}}$ & & $\stackrel{8}{\circ}$ \\
\hline & 承 & $\stackrel{n}{\dddot{0}}$ & & 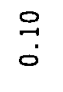 & $\stackrel{\infty}{\because}$ & & $\stackrel{i}{\sim}$ \\
\hline & 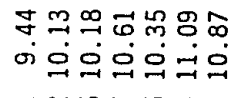 & $\stackrel{\vec{N}}{\dot{\sigma}}$ & & $\approx$ & $g$ & & $\stackrel{g}{\stackrel{9}{0}}$ \\
\hline & & 帝 & & $\overrightarrow{\vec{b}}$ & $\overrightarrow{0}$ & & $\stackrel{\nexists}{\dot{\sigma}}$ \\
\hline & $\begin{array}{l}\overrightarrow{0} .8 \\
\dot{0} \\
\dot{0}\end{array}$ & $\exists$ & & . & $\begin{array}{l}\text { 另 } \\
\text { in }\end{array}$ & & 怘 \\
\hline & 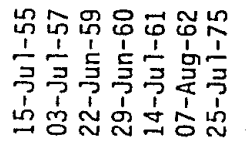 & $\begin{array}{l}\stackrel{\sim}{p} \\
\frac{1}{3} \\
? \\
? \\
\infty \\
\sim\end{array}$ & 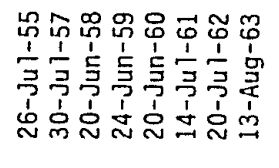 & 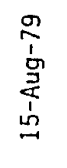 & 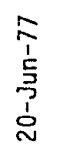 & 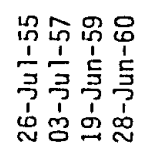 & 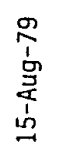 \\
\hline & 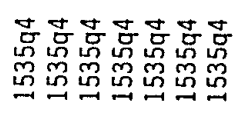 & $\overline{0}$ & on & $\vec{\Xi}$ & $\vec{I}$ & $\overrightarrow{\mathrm{c}}$ & 鸽 \\
\hline
\end{tabular}


APPENDIX 3

WATER QUALITY ANALYSES DATA - "180-FO0T" PRESSURE AQUIFER - AVERAGED BY DECADE THROUGHOUT STUDY AREA

Averaged data by decade for major anions and cations. Units are in percentage (Appendix 2).

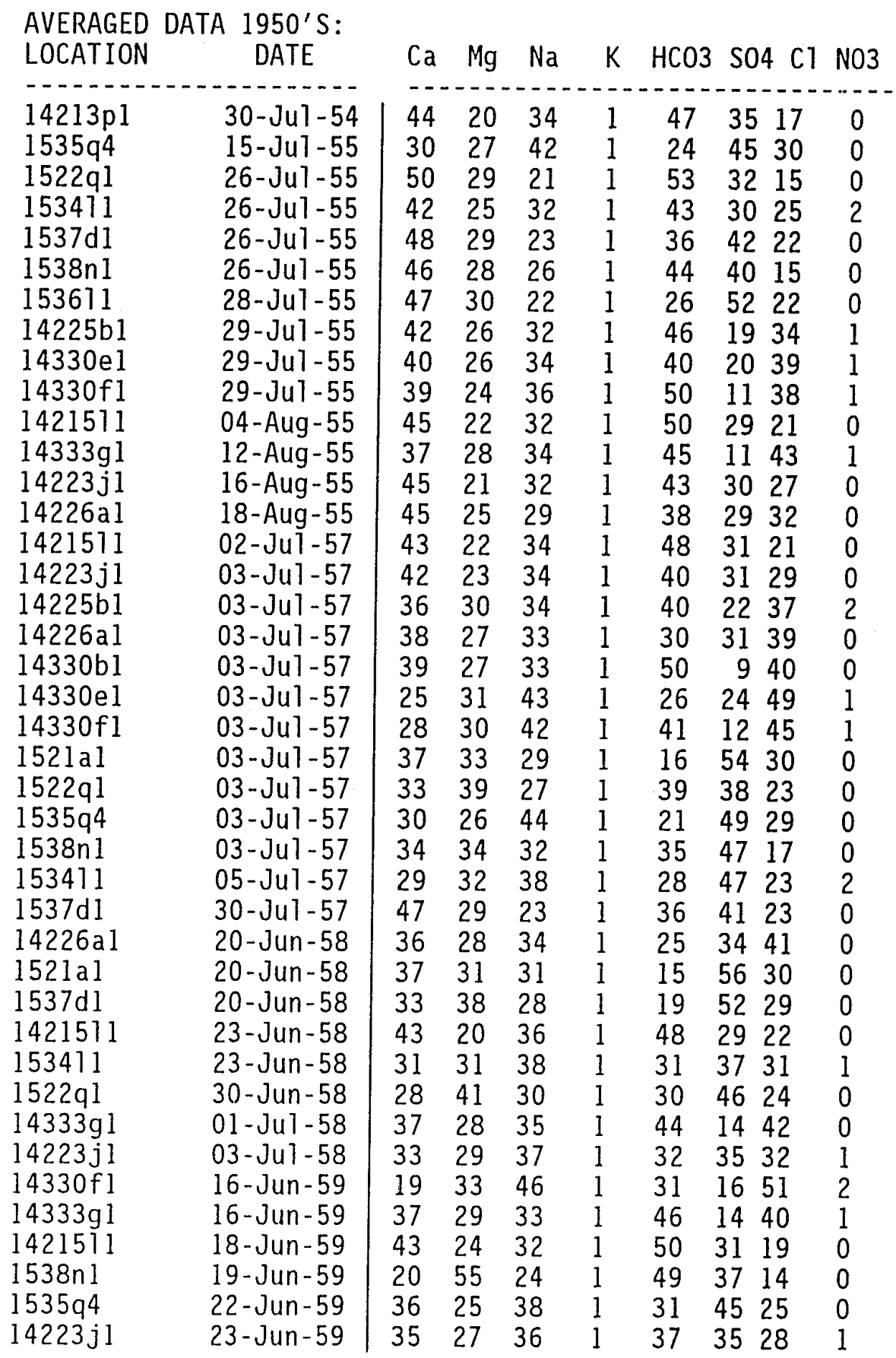


AVERAGED DATA 1950'S:

\begin{tabular}{|c|c|c|c|c|c|c|c|c|}
\hline LOCATION & DATE & $\mathrm{Ca}$ & $\mathrm{Mg}$ & $\mathrm{Na}$ & 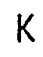 & $\mathrm{HCO} 3$ & $\mathrm{SO} 4 \mathrm{Cl}$ & N03 \\
\hline $\begin{array}{l}14226 \mathrm{al} 1 \\
1522 \mathrm{q} 1 \\
153411 \\
1537 \mathrm{~d} 1\end{array}$ & $\begin{array}{l}23-\text { Jun }-59 \\
23-J u n-59 \\
23-J u n-59 \\
24-J u n-59\end{array}$ & $\begin{array}{l}42 \\
34 \\
21 \\
32\end{array}$ & $\begin{array}{l}29 \\
40 \\
37 \\
38\end{array}$ & $\begin{array}{l}28 \\
25 \\
41 \\
28\end{array}$ & $\begin{array}{l}1 \\
1 \\
1 \\
1\end{array}$ & $\begin{array}{l}30 \\
41 \\
19 \\
23\end{array}$ & $\begin{array}{ll}27 & 43 \\
39 & 20 \\
42 & 34 \\
50 & 27\end{array}$ & 0 \\
\hline AVERAGE & & 37 & 29 & 33 & 1 & 36 & 3330 & 1 \\
\hline
\end{tabular}

AVERAGED DATA $1960^{\prime} \mathrm{S}$ :

\begin{tabular}{|c|c|c|c|c|c|c|c|c|}
\hline LOCATION & DATE & $\mathrm{Ca}$ & $\mathrm{Mg}$ & $\mathrm{Na}$ & $k$ & $\mathrm{HCO}$ & S04 Cl & NO3 \\
\hline 1421511 & $20-J u n-60$ & 34 & 27 & 38 & 1 & 43 & 3522 & 0 \\
\hline $1522 q 1$ & $20-J u n-60$ & 39 & 37 & 23 & 1 & 43 & 3621 & 0 \\
\hline 1537d1 & $20-J u n-60$ & 32 & 38 & 29 & 1 & 20 & $50 \quad 29$ & 0 \\
\hline $14223 j 1$ & 22-Jun-60 & 46 & 23 & 30 & 1 & 43 & 2828 & 1 \\
\hline $14226 a 1$ & 22-Jun-60 & 34 & 31 & 35 & 1 & 20 & 3544 & 0 \\
\hline $14330 \mathrm{fl}$ & 23-Jun-60 & 17 & 35 & 47 & 1 & 25 & 1954 & 2 \\
\hline $14333 \mathrm{gl}$ & $28-J u n-60$ & 39 & 28 & 32 & 1 & 45 & 1539 & 1 \\
\hline $1538 n 1$ & 28-Jun-60 & 28 & 39 & 33 & 1 & 32 & $49 \quad 19$ & 0 \\
\hline $1535 q 4$ & 29-Jun-60 & 20 & 31 & 49 & 1 & 15 & 5431 & 0 \\
\hline 1421511 & $12-J u 1-61$ & 29 & 33 & 37 & 1 & 49 & 3120 & 0 \\
\hline $14223 j 1$ & 13-Ju1-61 & 34 & 27 & 37 & 1 & 32 & 3434 & 1 \\
\hline 14226al & $13-J u 7-61$ & 42 & 28 & 30 & 1 & 29 & 3140 & 0 \\
\hline $14330 \mathrm{fl}$ & $13-J u 1-61$ & 27 & 29 & 44 & 0 & 32 & 1751 & 0 \\
\hline $14333 \mathrm{gl}$ & $13-J u 1-61$ & 34 & 33 & 33 & 1 & 45 & 1539 & 1 \\
\hline 153 & $14-J u\rceil-61$ & 22 & 29 & 48 & 1 & 14 & 5531 & 0 \\
\hline $1537 \mathrm{~d} 1$ & 4] -61 & 34 & 37 & 28 & 1 & 20 & 5228 & 0 \\
\hline $1522 q 1$ & $09-J u 7-62$ & 37 & 35 & 28 & 1 & 44 & 3818 & 0 \\
\hline $14225 \mathrm{bl}$ & 12-JuT-62 & 43 & 25 & 32 & 1 & 39 & 2536 & 1 \\
\hline $14330 \mathrm{el}$ & $12-J u 7-62$ & 60 & 14 & 26 & 0 & 36 & 2341 & 1 \\
\hline$f 1$ & $12-J u 1-62$ & 25 & 29 & 45 & 1 & 28 & 2148 & 2 \\
\hline 71 & $41-62$ & 36 & 24 & 38 & 1 & 42 & $\begin{array}{ll}37 & 21\end{array}$ & $\begin{array}{l}0 \\
0\end{array}$ \\
\hline $\begin{array}{l}142 \\
143\end{array}$ & $17-62$ & 39 & 27 & 33 & 1 & 25 & $\begin{array}{ll}32 & 43 \\
19 & 35\end{array}$ & 0 \\
\hline $\begin{array}{l}143 \\
153\end{array}$ & Ju1 -62 & 38 & $\begin{array}{l}26 \\
27\end{array}$ & $\begin{array}{l}35 \\
27\end{array}$ & 1 & 45 & $\begin{array}{ll}19 & 35 \\
51 & 30\end{array}$ & $\begin{array}{l}1 \\
0\end{array}$ \\
\hline $3 j 1$ & $\begin{array}{l}-62 \\
-62\end{array}$ & $\begin{array}{l}35 \\
32\end{array}$ & $\begin{array}{l}31 \\
28\end{array}$ & $\begin{array}{l}21 \\
39\end{array}$ & $\begin{array}{l}1 \\
1\end{array}$ & $\begin{array}{l}19 \\
27\end{array}$ & $\begin{array}{ll}51 & 30 \\
36 & 35\end{array}$ & 1 \\
\hline $1535 q 4$ & $07-A u g-62$ & 24 & 26 & 49 & 1 & 11 & 5831 & 0 \\
\hline $1522 q 1$ & $01-J u n-63$ & 28 & 42 & 29 & 1 & 39 & 4220 & 0 \\
\hline $1537 d l$ & Aug -63 & 32 & 42 & 25 & 1 & 28 & 4626 & 0 \\
\hline 14333gl & Aug- 63 & 35 & 29 & 35 & 1 & 47 & 2230 & 1 \\
\hline Oel & Aug -63 & 30 & 32 & 37 & 1 & 26 & 2548 & 1 \\
\hline 14 & $07-$ Aug -64 & 33 & 28 & 37 & 1 & 31 & $34 \quad 34$ & 1 \\
\hline & 26-Aug- 64 & 58 & 8 & 33 & 1 & 45 & 743 & 5 \\
\hline & $28-J u T-65$ & 40 & 23 & 36 & 1 & 32 & $32 \quad 34$ & 1 \\
\hline & $\lg -65$ & 42 & 23 & 34 & 1 & 38 & 2436 & 2 \\
\hline & & 40 & 26 & 33 & 1 & 35 & 3133 & 1 \\
\hline
\end{tabular}




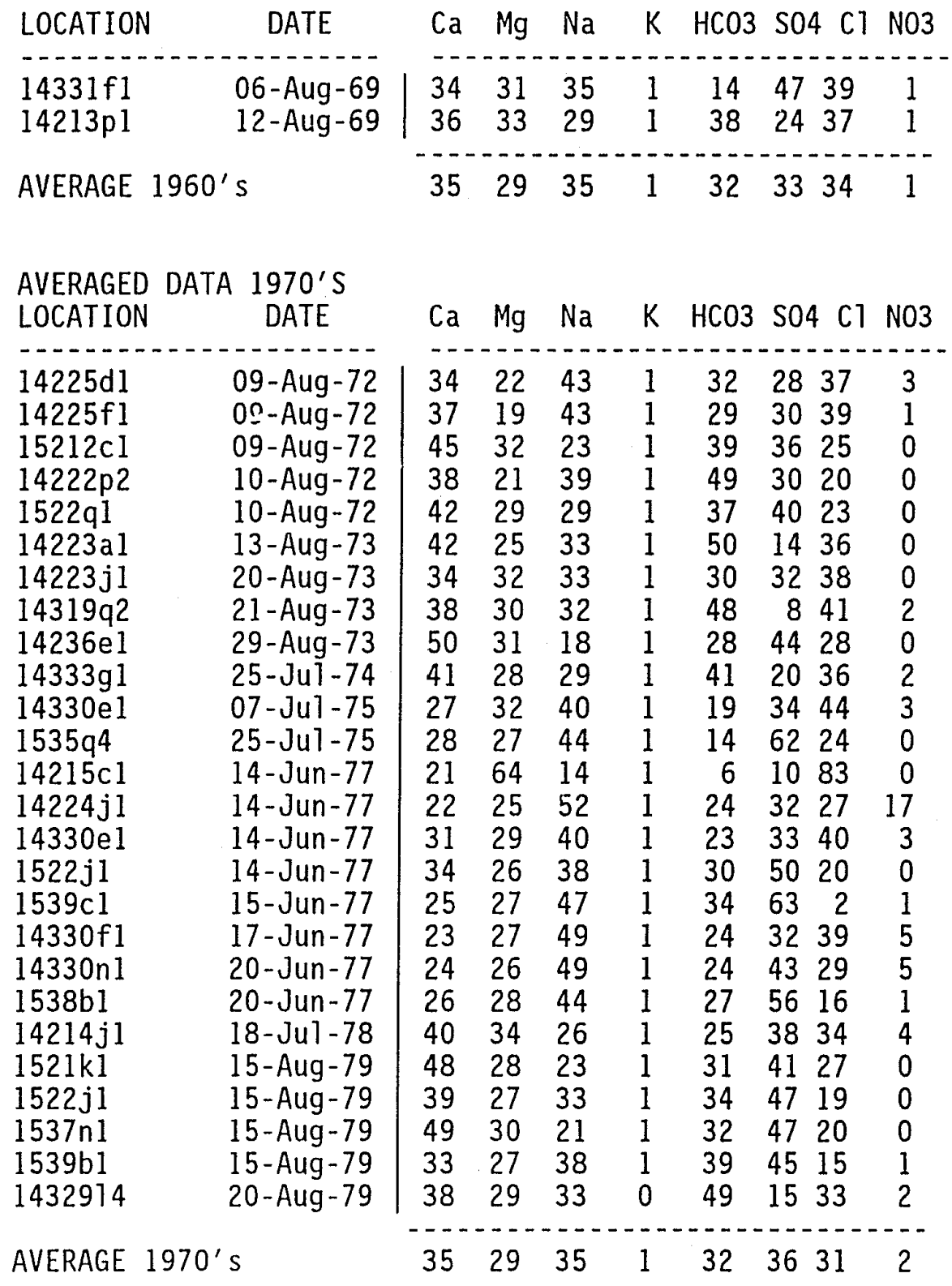




\section{APPENDIX 4}

\section{WATER QUALITY ANALYSES DATA - "180-F00T" PRESSURE AQUIFER - AVERAGE BY SUBAREA}

Averaged data by general area for major anions and cations. Units are in percentage (Appendix 2).

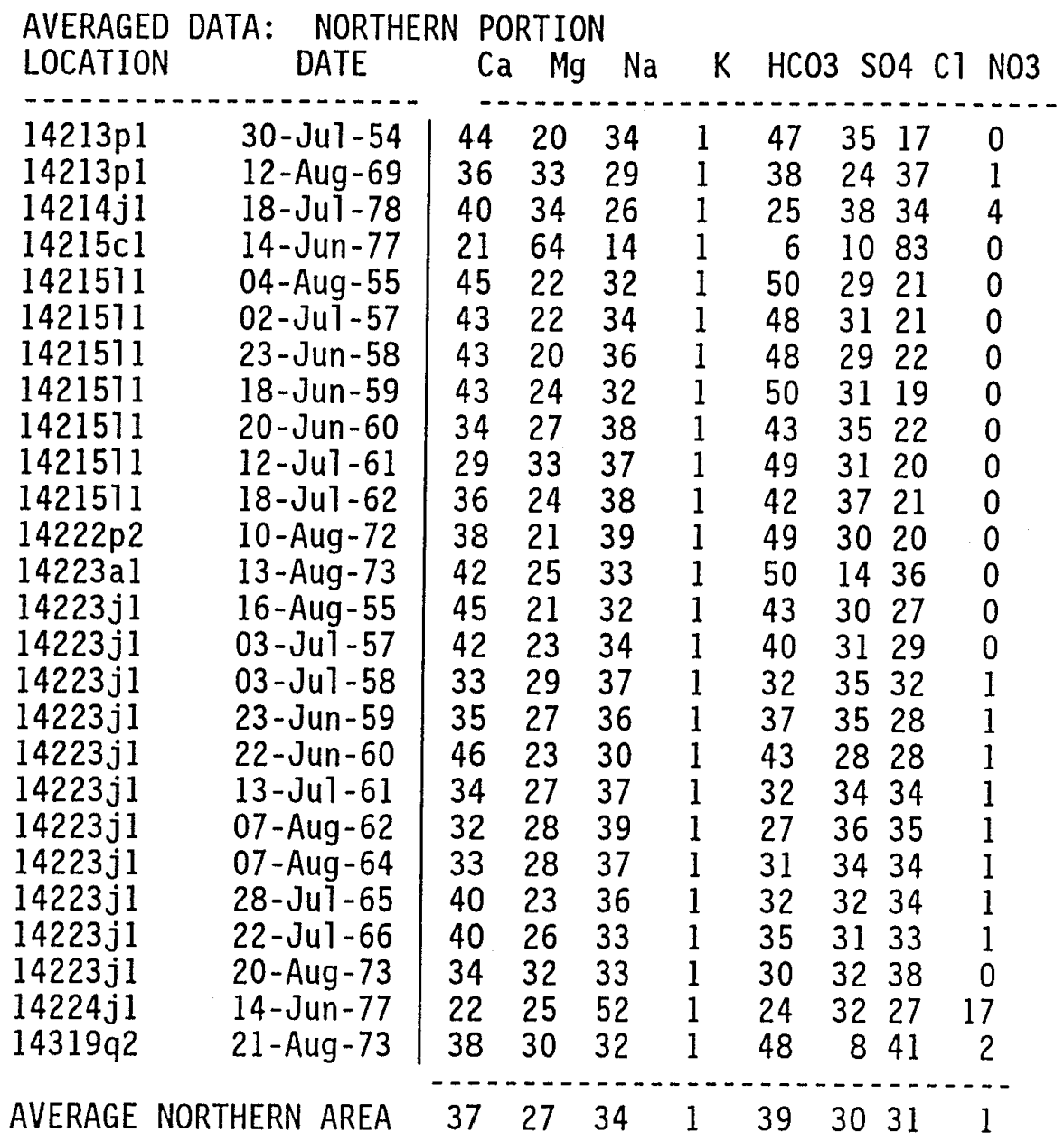

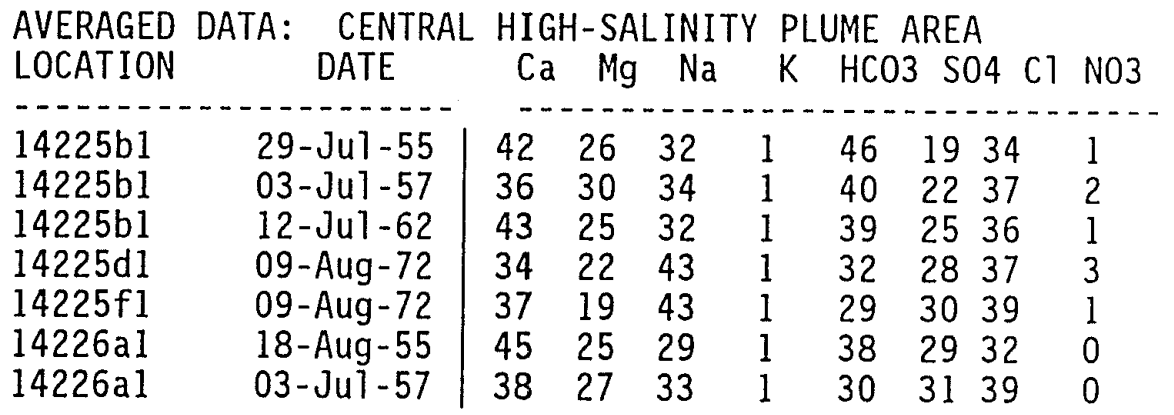


AVERAGED DATA: CENTRAL HIGH-SALINITY PLUME AREA

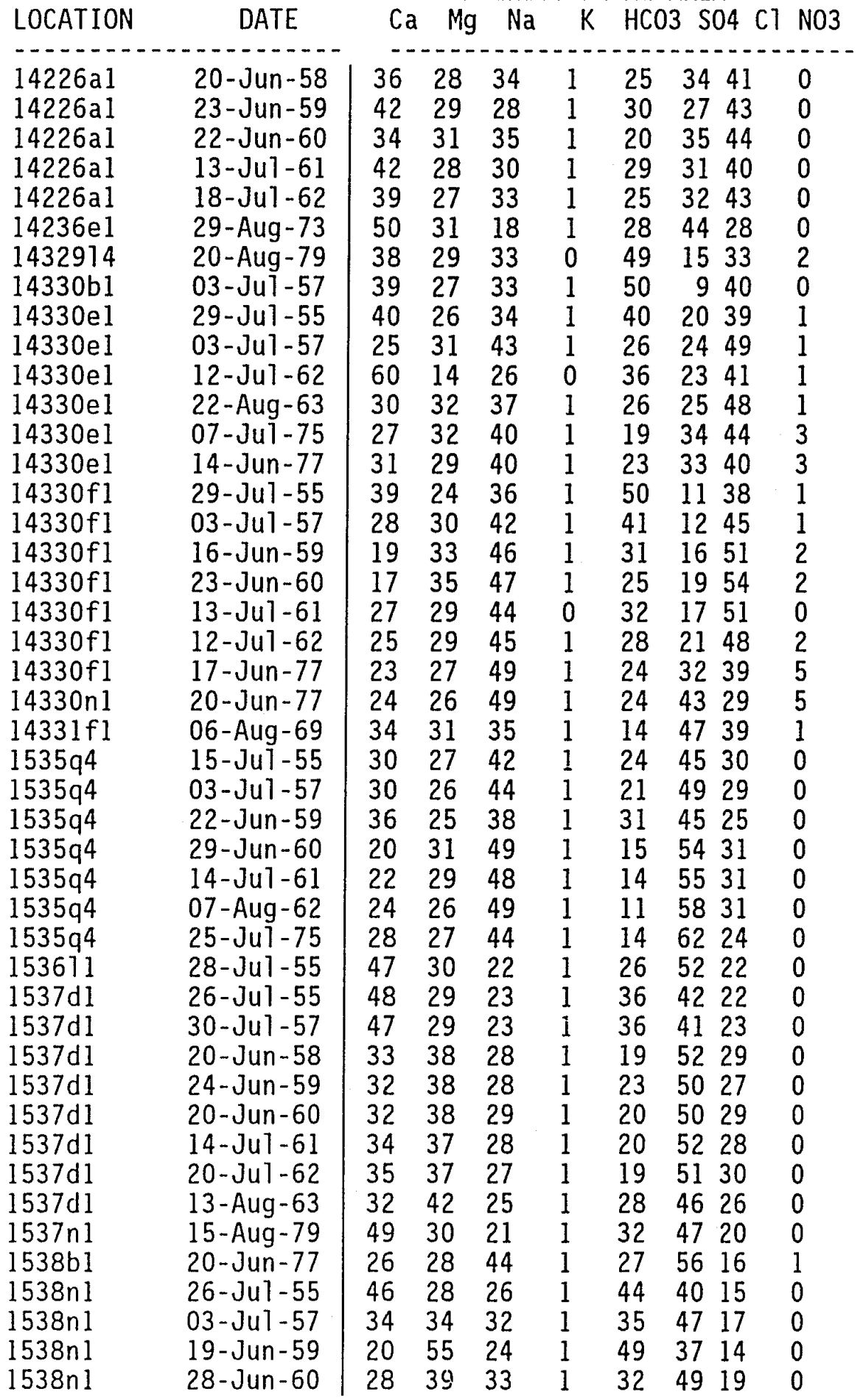




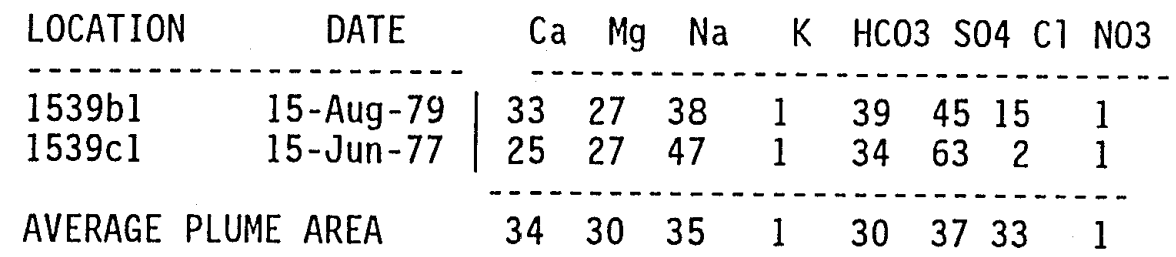

AVERAGED DATA: SOUTHERN AREA

\begin{tabular}{|c|c|c|c|c|c|c|c|}
\hline $\begin{array}{l}14333 \mathrm{gl} \\
14333 \mathrm{gl} \\
14333 \mathrm{gl} \\
14333 \mathrm{gl} \\
14333 \mathrm{gl} \\
14333 \mathrm{gl} \\
14333 \mathrm{gl} \\
14333 \mathrm{gl} \\
14333 \mathrm{gl} 1 \\
14333 \mathrm{gl} \\
15212 \mathrm{cl} \\
1521 \mathrm{al} \\
1521 \mathrm{al} \\
1521 \mathrm{kl} \\
1522 \mathrm{jl} \\
1522 \mathrm{jl} \\
1522 \mathrm{q} 1 \\
1522 \mathrm{q} 1 \\
1522 \mathrm{ql} \\
1522 \mathrm{ql} \\
1522 \mathrm{ql} \\
1522 \mathrm{ql} \\
1522 \mathrm{ql} \\
1522 \mathrm{q} 1 \\
153411 \\
153411 \\
153411 \\
153411\end{array}$ & 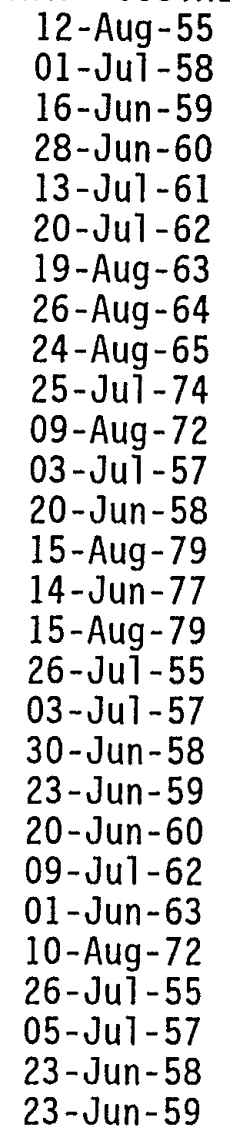 & $\begin{array}{l}37 \\
37 \\
37 \\
39 \\
34 \\
38 \\
35 \\
58 \\
42 \\
41 \\
45 \\
37 \\
37 \\
48 \\
34 \\
39 \\
50 \\
33 \\
28 \\
34 \\
39 \\
37 \\
28 \\
42 \\
42 \\
29 \\
31 \\
21\end{array}$ & $\begin{array}{r}28 \\
28 \\
29 \\
28 \\
33 \\
26 \\
29 \\
8 \\
23 \\
28 \\
32 \\
33 \\
31 \\
28 \\
26 \\
27 \\
29 \\
39 \\
41 \\
40 \\
37 \\
35 \\
42 \\
29 \\
25 \\
32 \\
31 \\
37\end{array}$ & $\begin{array}{l}34 \\
35 \\
33 \\
32 \\
33 \\
35 \\
35 \\
33 \\
34 \\
29 \\
23 \\
29 \\
31 \\
23 \\
38 \\
33 \\
21 \\
27 \\
30 \\
25 \\
23 \\
28 \\
29 \\
29 \\
32 \\
38 \\
38 \\
41\end{array}$ & $\begin{array}{l}1 \\
1 \\
1 \\
1 \\
1 \\
1 \\
1 \\
1 \\
1 \\
1 \\
1 \\
1 \\
1 \\
1 \\
1 \\
1 \\
1 \\
1 \\
1 \\
1 \\
1 \\
1 \\
1 \\
1 \\
1 \\
1\end{array}$ & $\begin{array}{l}45 \\
44 \\
46 \\
45 \\
45 \\
45 \\
47 \\
45 \\
38 \\
41 \\
39 \\
16 \\
15 \\
31 \\
30 \\
34 \\
53 \\
39 \\
30 \\
41 \\
43 \\
44 \\
39 \\
37 \\
43 \\
28 \\
31 \\
19\end{array}$ & $\begin{array}{rl}11 & 43 \\
14 & 42 \\
14 & 40 \\
15 & 39 \\
15 & 39 \\
19 & 35 \\
22 & 30 \\
7 & 43 \\
24 & 36 \\
20 & 36 \\
36 & 25 \\
54 & 30 \\
56 & 30 \\
41 & 27 \\
50 & 20 \\
47 & 19 \\
32 & 15 \\
38 & 23 \\
46 & 24 \\
39 & 20 \\
36 & 21 \\
38 & 18 \\
42 & 20 \\
40 & 23 \\
30 & 25 \\
47 & 23 \\
37 & 31 \\
42 & 34\end{array}$ \\
\hline OVLINUL & IERN AREA & 38 & 30 & 31 & & 38 & 3329 \\
\hline
\end{tabular}


APPENDIX 5

PIEZOMETRIC SURFACE ELEVATIONS - "180-FOOT" PRESSURE AQUIFER

Obtained from Monterey County Water Resources Agency

\begin{tabular}{|c|c|c|c|c|c|c|c|}
\hline \multicolumn{2}{|c|}{ Well 14S/2E-13B2: } & \multicolumn{2}{|c|}{ Well 14S/2E-14E1: } & \multicolumn{2}{|c|}{ Well 14S/2E-15G1: } & \multicolumn{2}{|c|}{ Hell 14S/2E-22P2: } \\
\hline $\begin{array}{c}\text { DATE } \\
\text { MEASURED }\end{array}$ & $\begin{array}{l}\text { ELEVATION } \\
\text { (feet) }\end{array}$ & $\begin{array}{c}\text { DATE } \\
\text { MEASURED }\end{array}$ & $\begin{array}{l}\text { ELEVATION } \\
\text { (feet) }\end{array}$ & $\begin{array}{c}\text { DATE } \\
\text { MEASURED }\end{array}$ & $\begin{array}{l}\text { ELEVATION } \\
\text { (feet) }\end{array}$ & $\begin{array}{c}\text { DATE } \\
\text { MEASURED }\end{array}$ & $\begin{array}{l}\text { ELEVATION } \\
\text { (feet) }\end{array}$ \\
\hline - n & $\cdots+\cdots$ & 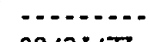 & $-2-2-1$ & $-\cdots$ & 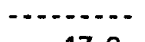 & 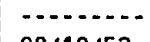 & $\cdots+\cdots$ \\
\hline $06 / 27 / 74$ & -20.3 & $08 / 23 / 73$ & -33.5 & $08 / 14 / 49$ & -17.9 & $08 / 10 / 52$ & -9.6 \\
\hline $08 / 18 / 74$ & -23.0 & $12 / 13 / 74$ & -6.7 & $08 / 13 / 50$ & -19.5 & $03 / 24 / 53$ & 4.6 \\
\hline $12 / 13 / 74$ & -1.0 & $11 / 24 / 75$ & -12.5 & $08 / 12 / 51$ & -19.3 & $08 / 15 / 54$ & -16.3 \\
\hline $08 / 17 / 75$ & -25.3 & $08 / 22 / 76$ & -40.8 & $11 / 29 / 52$ & 3.5 & $08 / 28 / 55$ & -12.2 \\
\hline $11 / 21 / 75$ & -5.9 & $12 / 08 / 76$ & -16.8 & $03 / 24 / 53$ & 3.2 & $12 / 08 / 55$ & -1.6 \\
\hline $12 / 07 / 76$ & -16.7 & $11 / 18 / 77$ & -23.9 & $08 / 16 / 53$ & -13.5 & $03 / 16 / 56$ & 5.8 \\
\hline $08 / 28 / 77$ & -33.9 & $12 / 05 / 78$ & -14.0 & $08 / 15 / 54$ & -14.5 & $08 / 20 / 56$ & -12.2 \\
\hline $11 / 17 / 77$ & -21.4 & $08 / 24 / 79$ & -33.7 & $12 / 08 / 55$ & 1.6 & $12 / 10 / 56$ & 2.5 \\
\hline $12 / 06 / 78$ & -8.9 & $12 / 03 / 79$ & -13.3 & $03 / 16 / 56$ & 3.5 & $03 / 21 / 57$ & 8.2 \\
\hline $08 / 24 / 79$ & -28.1 & $08 / 30 / 80$ & -32.4 & $08 / 20 / 56$ & -17.0 & $08 / 17 / 57$ & -16.1 \\
\hline $12 / 03 / 79$ & -9.4 & $12 / 09 / 80$ & -14.5 & $12 / 03 / 56$ & -1.2 & $11 / 15 / 57$ & -3.2 \\
\hline $12 / 09 / 80$ & -11.4 & $09 / 10 / 81$ & -33.0 & $03 / 22 / 57$ & 6.4 & $03 / 19 / 58$ & 8.4 \\
\hline $08 / 31 / 81$ & -29.7 & $12 / 10 / 81$ & -13.0 & $11 / 18 / 57$ & -3.7 & $11 / 17 / 58$ & 1.2 \\
\hline $12 / 11 / 81$ & -8.0 & $08 / 22 / 82$ & -30.0 & $03 / 19 / 58$ & 7.7 & $03 / 18 / 59$ & 5.5 \\
\hline $08 / 22 / 82$ & -25.8 & $12 / 14 / 82$ & -6.7 & $11 / 17 / 58$ & -1.3 & $08 / 15 / 59$ & -15.8 \\
\hline $12 / 14 / 82$ & -1.0 & $08 / 21 / 83$ & -25.4 & $03 / 18 / 59$ & 4.2 & $11 / 23 / 59$ & -0.6 \\
\hline $08 / 21 / 83$ & -19.3 & $12 / 02 / 83$ & -4.9 & $11 / 23 / 59$ & -3.6 & $03 / 24 / 60$ & 1.3 \\
\hline $12 / 05 / 83$ & 1.3 & $08 / 19 / 84$ & -31.8 & $03 / 24 / 60$ & 0.6 & $08 / 13 / 60$ & -16.0 \\
\hline $08 / 19 / 84$ & -26.6 & $12 / 19 / 84$ & -7.1 & $08 / 13 / 60$ & -22.2 & $12 / 06 / 60$ & 2.4 \\
\hline $12 / 19 / 84$ & -1.6 & $12 / 20 / 85$ & -10.2 & $12 / 06 / 60$ & 0.0 & $08 / 20 / 61$ & -18.8 \\
\hline $08 / 18 / 85$ & -46.4 & $08 / 17 / 86$ & -29.5 & $03 / 28 / 61$ & 1.7 & $12 / 18 / 61$ & 0.0 \\
\hline $12 / 23 / 85$ & -7.4 & $12 / 11 / 86$ & -13.1 & $08 / 20 / 61$ & -17.6 & $03 / 28 / 62$ & 3.0 \\
\hline $08 / 17 / 86$ & -24.4 & $08 / 16 / 87$ & -34.7 & $12 / 19 / 61$ & -2.5 & $12 / 04 / 62$ & -3.3 \\
\hline $12 / 12 / 86$ & -14.3 & $12 / 14 / 87$ & -13.2 & $03 / 28 / 62$ & 2.2 & $03 / 19 / 63$ & 3.3 \\
\hline $08 / 16 / 87$ & -29.9 & $08 / 14 / 88$ & -37.7 & $12 / 05 / 62$ & -6.5 & $08 / 18 / 63$ & -17.9 \\
\hline $12 / 09 / 87$ & -9.1 & $12 / 13 / 88$ & -18.0 & $03 / 19 / 63$ & 1.2 & $12 / 12 / 63$ & 1.9 \\
\hline $08 / 14 / 88$ & -38.0 & $12 / 08 / 89$ & -19.9 & $08 / 18 / 63$ & -23.0 & $03 / 25 / 64$ & -2.2 \\
\hline $12 / 13 / 88$ & -13.9 & $12 / 03 / 90$ & -31.2 & $12 / 16 / 63$ & 0.0 & $08 / 16 / 64$ & -20.5 \\
\hline $12 / 08 / 89$ & -17.4 & & & $03 / 30 / 64$ & -2.4 & $12 / 09 / 64$ & -1.3 \\
\hline $12 / 03 / 90$ & -24.8 & & & $08 / 16 / 64$ & -23.3 & $03 / 22 / 65$ & -1.8 \\
\hline & & & & $12 / 09 / 64$ & -4.2 & $08 / 22 / 65$ & -20.3 \\
\hline & & & & $08 / 22 / 65$ & -22.8 & $12 / 08 / 65$ & -0.9 \\
\hline & & & & $\begin{array}{l}12 / 09 / 65 \\
03 / 23 / 66\end{array}$ & $\begin{array}{l}-3.7 \\
-4.8\end{array}$ & $\begin{array}{l}03 / 24 / 66 \\
08 / 21 / 66\end{array}$ & $\begin{array}{r}-4.9 \\
-20.3\end{array}$ \\
\hline & & & & $08 / 21 / 66$ & -26.1 & $12 / 15 / 66$ & -1.0 \\
\hline & & & & $12 / 19 / 66$ & -3.5 & $08 / 27 / 67$ & -18.3 \\
\hline & & & & $08 / 27 / 67$ & -23.0 & $12 / 15 / 67$ & -1.0 \\
\hline & & & & $12 / 14 / 67$ & -2.2 & $08 / 18 / 68$ & -23.5 \\
\hline & & & & $\begin{array}{l}11 / 27 / 68 \\
08 / 31 / 69\end{array}$ & $\begin{array}{r}-7.9 \\
-230\end{array}$ & $\begin{array}{l}11 / 27 / 68 \\
12 / 03 / 60\end{array}$ & $\begin{array}{l}-4.2 \\
-3.3\end{array}$ \\
\hline & & & & $12 / 03 / 69$ & -5.3 & $08 / 23 / 70$ & -19.5 \\
\hline & & & & $11 / 23 / 70$ & -2.0 & $11 / 23 / 70$ & -0.6 \\
\hline & & & & $08 / 15 / 71$ & -25.4 & $11 / 17 / 71$ & -3.6 \\
\hline & & & & $08 / 27 / 71$ & -32.3 & $08 / 27 / 72$ & -24.3 \\
\hline & & & & $11 / 17 / 71$ & -12.3 & $12 / 01 / 72$ & -5.5 \\
\hline & & & & $11 / 29 / 72$ & -7.9 & $08 / 26 / 73$ & -20.6 \\
\hline & & & & $08 / 26 / 73$ & -26.8 & $11 / 28 / 73$ & -2.4 \\
\hline & & & & $11 / 29 / 73$ & -5.4 & $08 / 18 / 74$ & -18.1 \\
\hline & & & & $08 / 18 / 74$ & -24.6 & $12 / 16 / 74$ & 1.5 \\
\hline & & & & $12 / 17 / 74$ & -0.6 & $08 / 17 / 75$ & -20.5 \\
\hline & & & & $08 / 17 / 75$ & -25.7 & $11 / 21 / 75$ & -4.2 \\
\hline & & & & $11 / 18 / 75$ & -7.4 & $08 / 22 / 76$ & -20.5 \\
\hline & & & & $08 / 22 / 76$ & -25.8 & $12 / 06 / 76$ & -7.0 \\
\hline
\end{tabular}




\begin{tabular}{|c|c|c|c|}
\hline $\begin{array}{c}\text { DATE } \\
\text { MEASURED }\end{array}$ & $\begin{array}{l}\text { ELEVATION } \\
\text { (feet) }\end{array}$ & $\begin{array}{c}\text { DATE } \\
\text { MEASURED }\end{array}$ & $\begin{array}{l}\text { ELEVATION } \\
\text { (feet) }\end{array}$ \\
\hline $\begin{array}{l}12 / 07 / 76 \\
08 / 28 / 77 \\
11 / 17 / 77 \\
08 / 20 / 78 \\
12 / 06 / 78 \\
08 / 24 / 79 \\
12 / 15 / 79 \\
08 / 30 / 80 \\
12 / 09 / 80 \\
08 / 30 / 81 \\
12 / 10 / 81 \\
12 / 13 / 82 \\
08 / 21 / 83 \\
12 / 05 / 83 \\
08 / 19 / 84 \\
12 / 21 / 84 \\
11 / 22 / 85 \\
08 / 17 / 86 \\
12 / 11 / 86 \\
08 / 16 / 87 \\
12 / 11 / 87 \\
08 / 14 / 88 \\
12 / 12 / 88\end{array}$ & $\begin{array}{r}-11.2 \\
-29.0 \\
-16.4 \\
-25.1 \\
-8.0 \\
-27.5 \\
-6.9 \\
-25.8 \\
-7.5 \\
-29.1 \\
-6.3 \\
-0.6 \\
-17.7 \\
1.4 \\
-24.2 \\
-1.1 \\
-6.5 \\
-22.0 \\
-6.6 \\
-26.4 \\
-6.2 \\
-29.1 \\
-8.9\end{array}$ & $\begin{array}{l}08 / 28 / 77 \\
11 / 21 / 77 \\
08 / 20 / 78 \\
12 / 05 / 78 \\
08 / 24 / 79 \\
12 / 06 / 79 \\
08 / 30 / 80 \\
12 / 09 / 80 \\
08 / 30 / 81 \\
12 / 11 / 81 \\
08 / 22 / 82 \\
12 / 13 / 82 \\
08 / 21 / 83 \\
12 / 02 / 83 \\
08 / 19 / 84 \\
12 / 11 / 84 \\
08 / 18 / 85 \\
12 / 19 / 85 \\
08 / 17 / 86 \\
12 / 11 / 86 \\
08 / 16 / 87 \\
12 / 11 / 87 \\
08 / 14 / 88 \\
12 / 14 / 88 \\
12 / 11 / 89 \\
12 / 12 / 90\end{array}$ & $\begin{array}{r}-24.7 \\
-10.8 \\
-23.5 \\
-4.1 \\
-22.9 \\
-3.7 \\
-23.1 \\
-4.8 \\
-25.1 \\
-3.4 \\
-21.3 \\
3.6 \\
-16.1 \\
0.4 \\
-23.9 \\
-3.4 \\
-36.3 \\
-5.7 \\
-20.6 \\
-4.8 \\
-26.0 \\
-5.4 \\
-31.1 \\
-8.8 \\
-10.5 \\
-16.2\end{array}$ \\
\hline
\end{tabular}




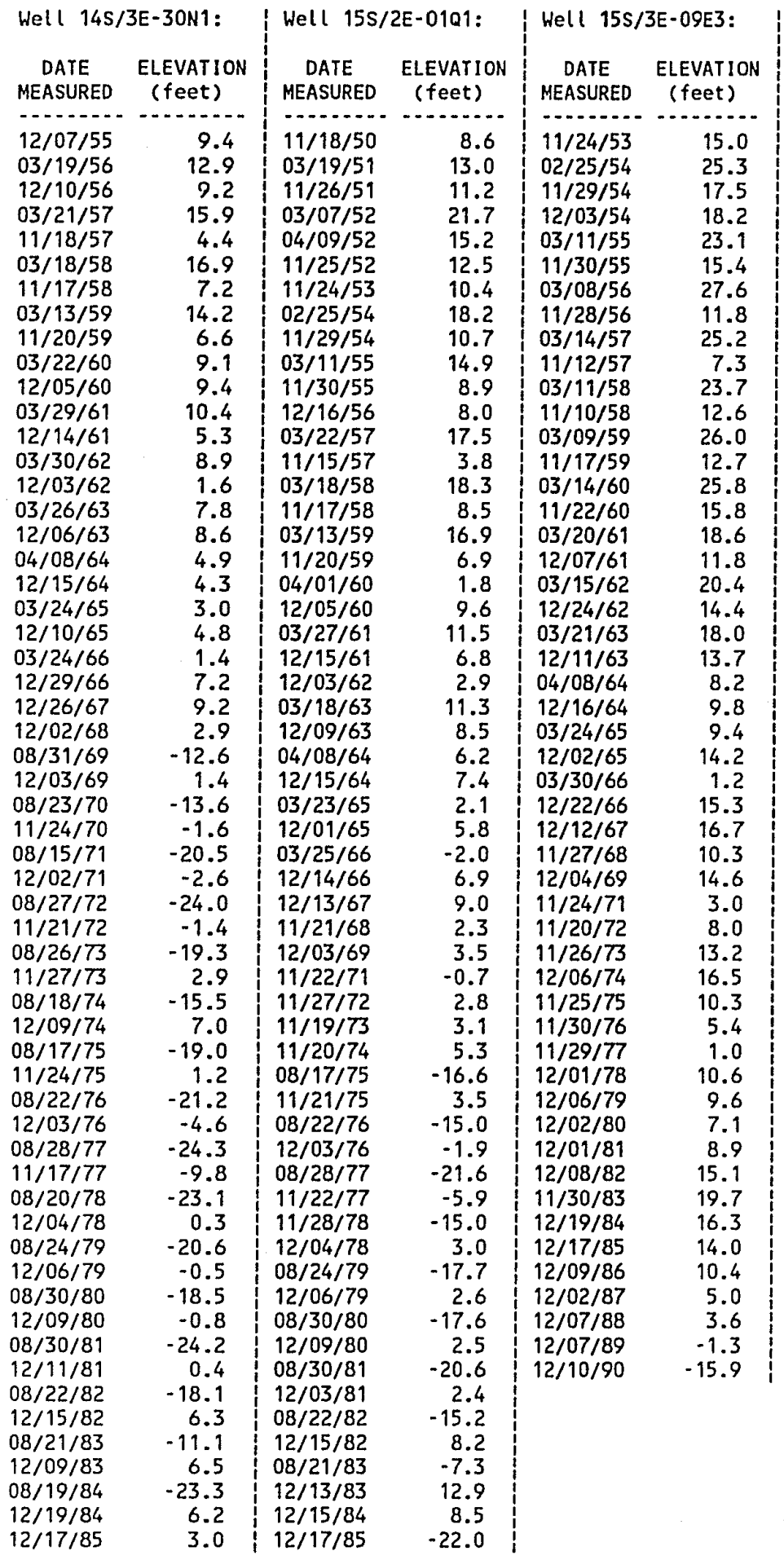




\begin{tabular}{|c|c|c|c|c|c|}
\hline $\begin{array}{c}\text { DATE } \\
\text { MEASURED }\end{array}$ & $\begin{array}{l}\text { ELEVATION } \\
\text { (feet) }\end{array}$ & $\begin{array}{c}\text { DATE } \\
\text { MEASURED }\end{array}$ & $\begin{array}{l}\text { ELEVATION } \\
\text { (feet) }\end{array}$ & DATE & ELEVATION \\
\hline $\begin{array}{l}08 / 17 / 86 \\
12 / 09 / 86 \\
08 / 16 / 87 \\
12 / 10 / 87 \\
08 / 14 / 88 \\
12 / 08 / 88 \\
12 / 06 / 89 \\
11 / 29 / 90\end{array}$ & $\begin{array}{r}-24.1 \\
0.1 \\
-29.1 \\
-3.4 \\
-28.8 \\
-4.8 \\
-9.2 \\
-19.0\end{array}$ & $\begin{array}{l}12 / 09 / 86 \\
08 / 16 / 87 \\
12 / 07 / 87 \\
08 / 14 / 88 \\
12 / 08 / 88 \\
12 / 19 / 89 \\
11 / 29 / 90\end{array}$ & $\begin{array}{r}7.5 \\
3.6 \\
2.2 \\
-26.3 \\
-2.5 \\
-6.6 \\
18.5\end{array}$ & & \\
\hline
\end{tabular}

